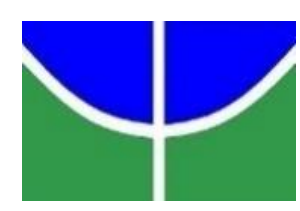

UNIVERSIDADE DE BRASÍLIA

INSTITUTO DE PSICOLOGIA

PROGRAMA DE PÓS-GRADUAÇÃO EM PSICOLOGIA CLÍNICA E CULTURA

\title{
Humor e Psicoterapia
}

Mariana Borges da Fonseca

Brasília, julho de 2016 


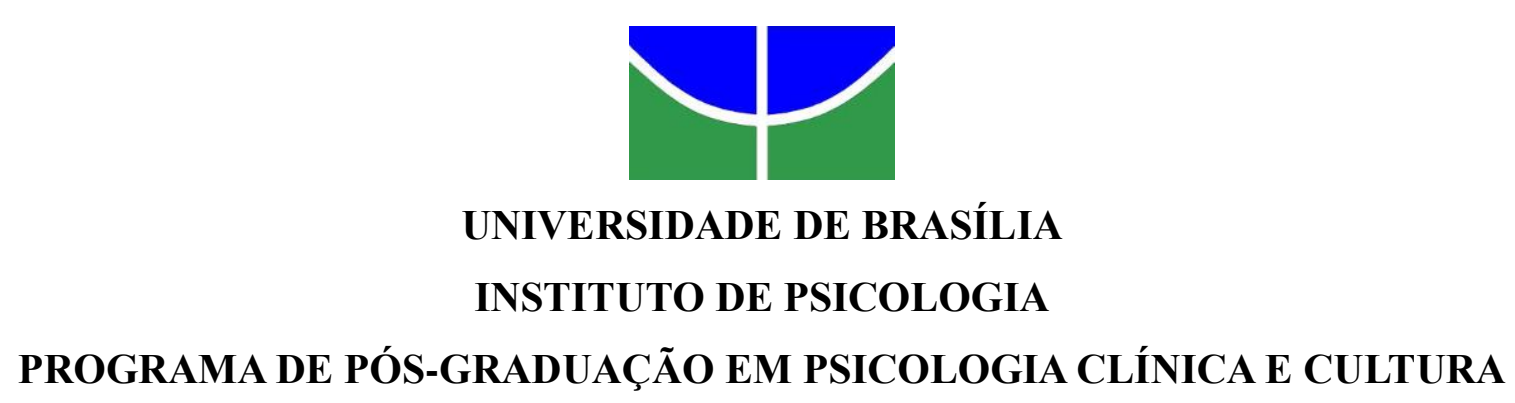

\title{
Humor e Psicoterapia
}

\author{
Mariana Borges da Fonseca
}

Dissertação apresentada ao Instituto de Psicologia da Universidade de Brasília, como requisito parcial para obtenção do título de Mestre em Psicologia Clínica e Cultura.

Orientadora: Profa. Dra. Valeska Maria Zanello de Loyola

Brasília, julho de 2016 


\section{UNIVERSIDADE DE BRASÍLIA \\ INSTITUTO DE PSICOLOGIA \\ PROGRAMA DE PÓS-GRADUAÇÃO EM PSICOLOGIA CLÍNICA E CULTURA}

DISSERTAÇÃO DE MESTRADO APROVADA PELA SEGUINTE BANCA EXAMINADORA:

Profa. Dra. Valeska Maria Zanello de Loyola - Presidente Instituto de Psicologia - Universidade de Brasília

Prof. Dr. Fauzi Nelson Paranhos Lopes Mansur (IFB) - Membro Externo Instituto Federal de Brasília

Profa. Dra. Maria Inês Gandolfo Conceição (PCL/UnB) - Membro Interno Instituto de Psicologia - Universidade de Brasília

Profa. Dra. Isabela Machado da Silva (PCL/UnB) - Membro Suplente Instituto de Psicologia - Universidade de Brasília

Brasília, julho de 2016 
A todos aqueles que já compartilharam de risos e choros comigo, especialmente aos meus pais, Cláudia e Robério, e aos meus avós, Marli e Geraldo. Eu amo vocês. 


\section{Agradecimentos}

Agradeço, primeiramente, aos meus pais, Claudia e Robério, por todo o apoio, carinho, amor, cuidado, puxões de orelha e investimentos emocionais e financeiros que me conduziram até aqui. Obrigada pelas noites mal dormidas, catarros puxados, colos, abraços, cafunés, almoços, jantas e incontáveis momentos de riso e brincadeiras ao redor da mesa. Esta dissertação é para vocês!

Aos meus avós, Marli e Geraldo, pelo carinho, amor e apoio que têm me dado ao longo de toda minha vida. Obrigada por estarem sempre na primeira fileira torcendo por mim. Obrigada pelos cursos pagos, pelas caronas dadas, pelos lanches passados pela janela, pelos cafezinhos, abraços e conversas. Vó, obrigada pelos almoços que você cozinhou pra eu me "alimentar direito". Eu amo vocês!

Ao meu companheiro de vida, Pedro Silveira. Amor, não sei como você conseguiu fazer isso, mas você tornou este processo de escrita muito menos solitário. Obrigada por todas as vezes que você leu e releu pedaços deste trabalho, pelos momentos de colo, de paciência e de incentivo. Obrigada por rir, pular, gritar e chorar comigo, por entender minhas ausências e me apoiar incondicionalmente. Eu amo muito você!

Aos meus irmãos, Vitor e Daniel, por terem me aturado durante este processo. Amo vocês, meus demônios!

Aos meus tios, Gilmara e Fábio, por todas as caronas, almoços e carinhos ao longo dos anos. A Amanda e a Fabiana, por torcerem por mim.

À minha sogra, Maria Fernanda, e meu sogro, Álvaro, por todo o apoio e amor que me dão.

À Prof ${ }^{a}$. Dra. Valeska Zanello, por ter me acolhido após a iniciação do Mestrado e por ter sugerido este tema tão lindo. Val, esse trabalho não teria sido possível, não fosse você. Obrigada pela orientação maravilhosa, diretiva e calorosa; pelo apoio e 
acompanhamento paciente e cuidadoso. Você encarna na sua orientação o empoderamento que estuda e ensina - e isso é muito lindo!

Às colegas do grupo de pesquisa Saúde Mental e Gênero, por terem também me acolhido tão prontamente, em especial: Gisele Dantas, Mariana Pedrosa, Marizete Gouveia, Naiara Windmöller e Aline Xavier. Meninas, vocês me inspiram.

Ao Prof. Dr. Maurício Neubern, por todo o incentivo, apoio e orientação dados ao longo dos anos. Maurício, sou profundamente grata a tudo o que aprendi com você.

Ao professor e amigo, Denis Camargo. Por me introduzir tão amorosamente à palhaçaria, por toda a disponibilidade, troca de ideias, exercícios, desafios e provocações. Denis, a sua humanidade me mostra que nós somos o que temos de mais valor! Obrigada por tudo.

Ao Prof. Dr. Marcus Mota, pelo suporte dado com a literatura e por responder tão prontamente às minhas dúvidas.

À Prof ${ }^{a}$. Dra. Nitza Tenenblat, pelos incontáveis cafezinhos e trocas de ideia. Por me motivar e incentivar constantemente com a sua energia amorosa e provocadora.

Ao psicólogo e professor Olavo Dalcanale Rigon Neto, por todo acolhimento, intervenções sob medida e supervisões realizadas ao longo dos anos. Aproveito para agradecer também a todos os colegas do Instituto Milton Erickson de Brasília, pelo apoio e aprendizado destes últimos dois anos.

À Tatiane Santana, amiga do coração. Tati, obrigada infinitamente por tudo que compartilhamos juntas durante esses últimos anos. Obrigada por ser uma grande companheira e parceira, por chorar, rir e pular comigo, por todo apoio, colo, motivação e conselho. Obrigada por não me deixar desistir. Você é foda!

À Rosanna Ribeiro, como amiga e como coacher. Rosanna, eu consegui!!! Obrigada por ter me ajudado a me organizar para que este trabalho pudesse sair com a dedicação 
merecida. Obrigada por acreditar profundamente em mim. Pelos transes, intervenções, papos e mensagens lindas de whatsapp em manhãs aleatórias.

À Melina Borges. Mulher, obrigada por nunca desistir de mim, e por estar sempre por perto, mesmo longe. Pela paciência, pelos questionamentos que me fazem repensar as coisas e por todo o carinho.

À Mariana Barbato, como amiga e massagista. Mari, sua linda, obrigada por me acompanhar nessa jornada com toda essa sua luz!

À Patrícia Milhomens, pelas trocas sempre maravilhosas e instigantes.

À Patrícia Loraine, por me acompanhar de diversas formas, inclusive espiritualmente, neste processo.

Ao meu ex-psicólogo Waldir Bezerra, pelo trabalho paciente e amoroso para que eu me aproximasse cada vez mais de mim.

Ao meu atual psicólogo, Miguel Batista, que tornou este processo bem mais leve e que tem me ajudado a crescer e cuidar de mim ao longo desta caminhada.

Aos meus pacientes, com quem eu aprendo tanto sobre a riqueza humana e a capacidade de nos reerguermos diante das mais difíceis circunstâncias.

À CAPES, pela bolsa que me concedeu no mestrado. O incentivo à ciência e à pesquisa é fundamental para o crescimento de uma nação - que não nos esqueçamos disso nos tempos políticos difíceis em que nos encontramos.

A todos os que marcaram minha vida de alguma forma. Ninguém cresce sozinho.

E, por fim, aos deuses e deusas, aos anjos, arcanjos e espíritos de luz, e os amigos espirituais que têm me acompanhado ao longo dessa jornada. Minha eterna gratidão. 


\section{Sumário}

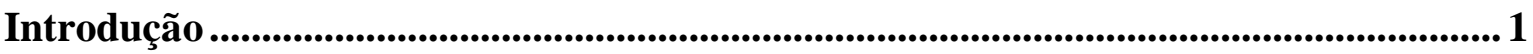

Capítulo 1 - "Está rindo do quê?": aproximações aos estudos, à natureza e à prática

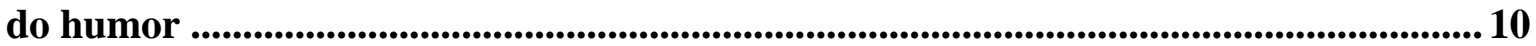

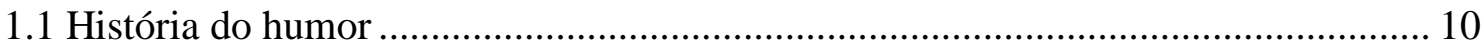

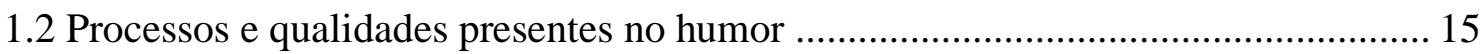

$1.3 \mathrm{O}$ caráter lúdico do humor: a brincadeira ................................................................. 23

1.4 O processo "incongruência-resolução" do humor ....................................................... 36

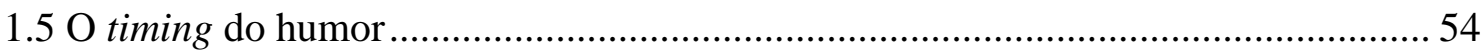

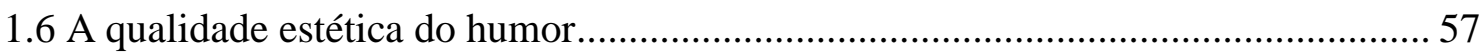

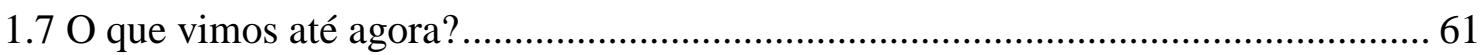

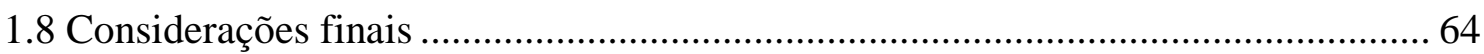

Capítulo 2 - "Rir é o melhor remédio"?: Aproximações às implicações do uso do humor na psicoterapia............................................................................................................... 67

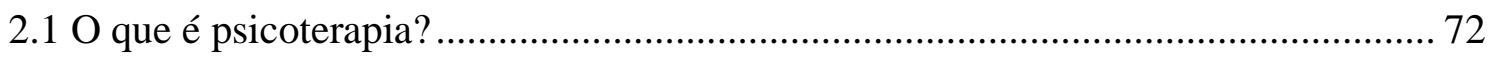

2.2 Meios psicológicos: relação e experiência.............................................................. 74

2.3 Objetivos gerais da psicoterapia: integração psíquica e empoderamento................. 77

2.4 Processos psicoterapêuticos: agentes específicos de mudança ................................. 85

2.5 Condições fundamentais: fatores comuns a todas as psicoterapias ......................... 93

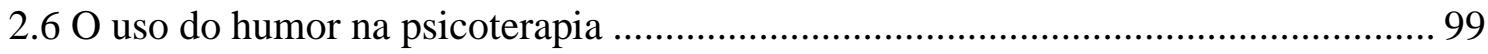

2.7 Meios psicológicos e humor: relação e experiência ............................................... 102

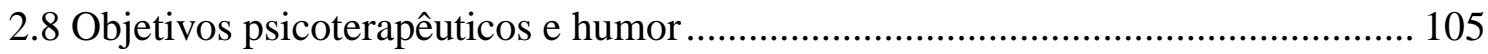

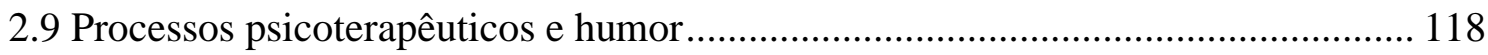

2.10 Condições fundamentais à psicoterapia e humor................................................. 131

$2.11 \mathrm{O}$ humor e a mudança de paradigma na clínica psicológica ................................ 141

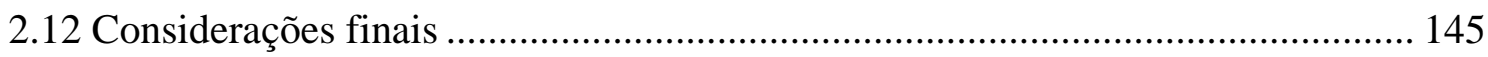

Capítulo 3 - É possível desenvolver o senso de humor do psicoterapeuta? Como? .. 147

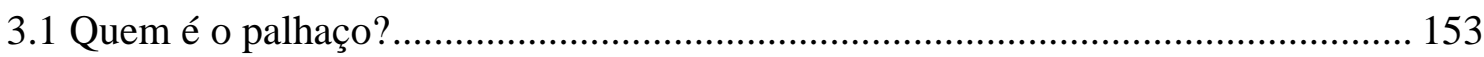

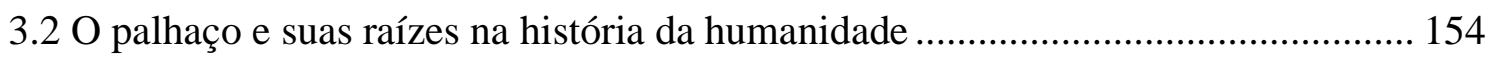

3.3 A figura do palhaço e as particularidades de seu trabalho..................................... 161

3.3.1 O palhaço: qualidades e processos............................................................... 162

3.4 A arte da palhaçaria: aprendizado e treinamento ................................................. 176

3.5 Contribuições do treinamento de palhaço para a clínica psicológica ...................... 192

3.5.1 Contribuições do clown para o desenvolvimento do senso de humor ............ 192 
3.5.2 Contribuições do clown para outros aspectos característicos da clínica

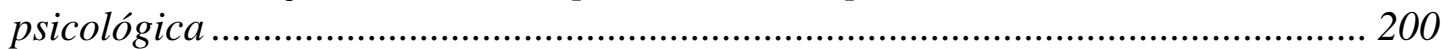

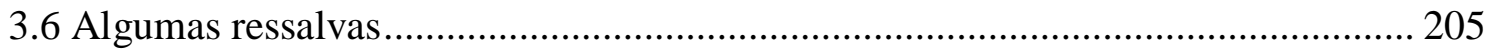

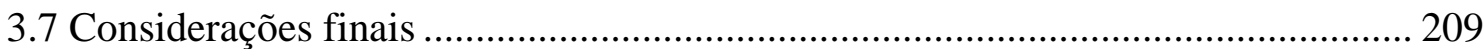

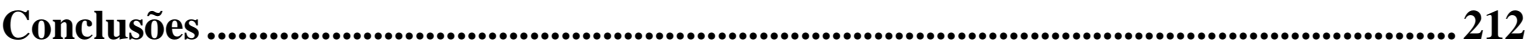

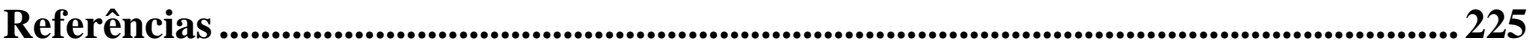




\section{Lista de quadros}

Quadro 1 A compreensão do humor como sério ou como não sério a partir da relação entre o fenômeno do humor e o entendimento sobre a seriedade. 36

Quadro 2 Diferenciação entre os Princípios Cooperativos da comunicação cotidiana e da comunicação humorada a partir da proposição de Raskin (1985) 44

Quadro 3 Divergências estéticas entre a comédia e tragédia a partir da perspectiva de

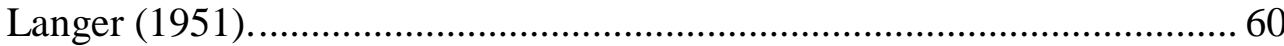

Quadro 4 Resumo da compreensão desenvolvida no Capítulo 1 sobre os processos e qualidades centrais na constituição do fenômeno humorado.

Quadro 5 Relações entre o fenômeno do humor e sua potencialização ou deflexão do contato na psicoterapia.

Quadro 6 O lugar do humor no setting psicoterapêutico 218 


\section{Lista de siglas e abreviaturas}

a.C. antes de Cristo

CAPES Coordenação de Aperfeiçoamento de Pessoal de Nível Superior

GTVH General Theory of Verbal Humor (Teoria Geral do Humor Verbal)

KR Knowledge Resources (Recursos de Conhecimento)

LA Language (Linguagem)

LM Logical Mechanism (Mecanismo Lógico)

NS Narrative Strategy (Estratégia Narrativa)

SI Situation (Situação)

SO Script Opposition (Oposição de Scripts)

SSTH Semantic-Script Theory of Humor (Teoria Script-Semântica do Humor)

STCW Sensitivity Training Clown Workshop (Oficina de Treinamento de Sensibilidade com Palhaços)

TA Target (Alvo) 


\section{Resumo}

Este trabalho visa discutir o uso do humor na psicoterapia. O humor é um dos fenômenos primários da vida humana. Ele integra as atividades e formas de vida das mais diversas culturas e sociedades, de modo que é natural que emerja também no contexto da psicoterapia. É importante, portanto, que o psicoterapeuta possa compreender o lugar que o fenômeno do humor ocupa nas particularidades do contexto psicoterapêutico, e como utilizá-lo para potencializar processos saudáveis na relação. Neste estudo teórico, apontamos e discutimos os principais processos e qualidades vivenciais do humor; refletimos sobre sua relação com os meios, objetivos, processos e condições que caracterizam as psicoterapias de forma geral; e assinalamos a arte da palhaçaria como uma possível ferramenta no desenvolvimento da sensibilidade e habilidade cômicas do psicoterapeuta. Compreendemos que, na psicoterapia, as trocas humorísticas pontuais atuam como um phármakon - podem potencializar processos de cura ou de adoecimento a depender da forma de seu uso -, ao passo que o senso de humor - enquanto forma mais geral de se relacionar com o mundo - é parte integral de um modo de vida saudável. Exercícios e práticas podem ajudar o terapeuta não apenas a desenvolver a sua capacidade de criar humor na psicoterapia, como a cultivar seu senso de humor. Neste sentido, concluímos que é de fundamental importância integrarmos o humor no paradigma psicoterapêutico, motivando seus estudos e práticas no contexto acadêmico e profissional.

Palavras-chave: humor, psicoterapia, palhaço, estética, estado cômico. 


\begin{abstract}
This work discusses the use of humor in psychotherapy. Humor is one of the primary phenomena of human life. It integrates the activities and life forms of different cultures and societies, in such a way that its emergence in the context of psychotherapy should be expected. Therefore, it's important for the psychotherapist to understand how humor phenomenon is related to the particularities of the psychotherapeutic context, and how it can be utilized to enhance healthy processes within the relationships of the individuals involved. In this theoretical study we pinpoint and discuss the main processes and experiential qualities of humor, as well as reflect over its relationship with the main goals, means, processes and conditions of psychotherapy, pointing the clowning arts as a potential tool in the development of the therapist's comic ability and sensibility. Our understanding is that a humorous exchange act like a phármakon - i.e. can enhance processes of healing or sickening, depending upon its use -, whereas the sense of humoras in a more general way of relating to the world - is an integral part of a healthy lifestyle. Exercises and practices can help the therapist not only to develop his/her ability to create humor in psychotherapy, but also to cultivate his/her sense of humor. Therefore, we advocate the importance of integrating humor into the psychotherapeutic paradigm, motivating its study and practice in the academic and professional environment.
\end{abstract}

Keywords: humor, psychotherapy, clown, aesthetics, comic state. 


\section{Introdução}

Humor heightens our sense of survival and preserves our sanity ${ }^{1}$.

Charles Chaplin

O humor é uma experiência característica da humanidade. Segundo pesquisadores, ele compõe o cotidiano das mais diversas culturas e grupos sociais, emergindo em diferentes circunstâncias e assumindo uma grande variedade de formas, sentidos e funções a depender do contexto de sua emergência (Attardo, 2008; Oring, 2008). Em vista disto, muitos estudiosos o consideram um fenômeno inerente às relações humanas (Bergson, 1903; Hempelmann, 2012; Pradita, 2010; Tanay, Roberts, \& Ream, 2012). Desta forma, é natural que o humor emerja também nas relações terapêuticas, demandando compreensão no que concerne ao lugar que ocupa no contexto dessas trocas (Greenwald, 1975; Sultanoff, 2013).

Em algumas sociedades primitivas, sabe-se que o humor ocupava um lugar central nos relacionamentos de cura (Koller \& Grisky, 2011; Van Blerkon, 1995) -, fosse nos grandes rituais, fosse em encontros particulares com o curandeiro da comunidade. Estudos registram que a figura que hoje conhecemos como "palhaço" se assemelha muito às figuras associadas à cura e à prosperidade nessas sociedades antigas (Langer, 1956; Van Blerkon, 1995).

Contudo, ao longo do tempo, o humor foi se tornando um tabu não somente nas ciências como no próprio imaginário social (Kuhlman, 1984; Neves, 1974). Com o

\footnotetext{
${ }^{1}$ Tradução nossa: "O humor potencializa nosso senso de sobrevivência e preserva nossa sanidade".
} 
advento da Igreja Católica, seu caráter prazeroso e subversivo o levou a ser considerado um fenômeno perigoso, que deveria ser vivenciado com cautela (Dorneles, 2003). Além disso, sua natureza ambígua, idiossincrática, complexa e lúdica o ilegitimavam perante uma visão positivista do conhecimento - focada na univocidade, universalidade, linearidade e rigidez como meio de se apropriar da realidade (Neves, 1974; Zanello, 2005). Nesta perspectiva, o humor passou a ser compreendido como uma troca irrelevante e ilusória - sem muitos sentidos ou mensagens pertinentes à realidade (Ruch, 2008) -, e a sua emergência em espaços terapêuticos terminou sendo banalizada, quando não censurada (Kuhlman, 1984; Tanay et al., 2012).

Foi apenas a partir dos anos 1960 que o fenômeno humorado voltou a aparecer como figura, principalmente em estudos e contextos voltados à saúde (Kuhlman, 1984; Saper, 1987). De lá para cá, graças a um menor dogmatismo e um maior diálogo entre as diversas áreas de conhecimento, os profissionais têm se tornado mais ecléticos, ampliando sua perspectiva para uma visão mais múltipla da realidade e valorizando a abertura para uma forma mais complexa e humana de se aproximar da mesma (Cordioli \& Giglio, 2008) - no que o humor tem conquistado novamente seu espaço (Kuhlman, 1984).

No contexto específico da psicoterapia, tem existido um crescente número de terapeutas e estudiosos interessados no humor. Destes, a grande maioria parece considerálo um importante fenômeno humano e uma potente ferramenta de mudança na relação (Greenwald, 1975; Jacobs, 2009; Kuhlman, 1984; Richman, 2001).

Para Richman (2001), o humor é um dos componentes vitais de um estilo de vida saudável, enquanto para autores como Chazenbalk (2005), Panichelli (2013) e Tanay et al. (2012), ele é um dos principais mecanismos de coping na lida com situações difíceis.

Da mesma forma, a capacidade de utilizar e apreciar o humor em psicoterapia tem sido ressaltada como uma importante característica a ser desenvolvida pelo psicoterapeuta. 
Segundo Sultanoff (2013), as intervenções humorísticas têm grande potencial de provocar processos de mudança, uma vez que a vivência do humor envolve e interpela as diferentes dimensões que constituem a vida do sujeito - social, pessoal, comportamental, emocional e fisiológica. Neste sentido, Kuhlman (1984) acrescenta que uma intervenção humorada pode impactar o processo psicoterapêutico tanto a curto como a longo prazo: a curto prazo o humor pode provocar uma mudança momentânea de perspectiva, aproximando ou distanciando o paciente da questão que precisa ser abordada, ao passo que a longo prazo, a troca humorada pode definir, moldar e mudar a qualidade do relacionamento não só entre os envolvidos, como também destes com as situações que os interpelam. Além disso, o humor é tido na literatura como uma experiência que pode deixar o paciente mais confortável para ser espontâneo e autêntico (Chazenbalk, 2005), favorecer o insight (Kuhlman, 1984; Rutherford, 1994), minimizar as resistências (Saper, 1987) e suavizar discussões que, do contrário, seriam intensas demais para serem produtivas (Rutherford, 1994).

Contudo, a emergência do humor em psicoterapia nem sempre é terapêutica: diversos psicoterapeutas reconhecem que o potencial de mobilização do humor também pode ser utilizado de modo a prejudicar o processo terapêutico em andamento (Kuhlman, 1984; Sultanoff, 2013). Segundo Saper (1987), a troca humorada pode ser utilizada pelo terapeuta ou paciente para desviar a atenção de uma questão desconfortável ou difícil, bem como para criticar ou agredir o outro sob um pretenso ar de brincadeira. Além disso, seu divertimento pode levar tanto paciente como terapeuta a se distraírem, esquecendo dos propósitos terapêuticos que pautam o encontro (Kuhlman, 1984).

Neste sentido, reconhecendo o caráter primordial que o humor possui nas relações humanas, a maioria dos autores ressalta a importância de que os terapeutas desenvolvam não apenas uma compreensão do lugar que o humor ocupa nas especificidades do contexto 
psicoterapêutico, como também um domínio sobre seu uso - de modo que as trocas humoradas possam ser direcionadas para produzir e potencializar processos saudáveis (Chazenbalk, 2005; Greenwald, 1975; Kuhlman, 1984; Richman, 2001; Rutherford, 1994; Saper, 1987).

No entanto, os avanços na compreensão e no cultivo do humor na psicoterapia têm sido marcados por dificuldades reminiscentes da visão positivista e do período de preconceito e ostracismo vivenciados pelo humor. Dentre estas dificuldades se encontram:

- O preconceito com relação ao humor nos contextos de saúde. Apesar das evoluções acima destacadas, ainda existe um considerável preconceito com relação à emergência do humor em contextos de saúde, especialmente por parte dos profissionais (Koller \& Gryski, 2007). Tanay et al.. (2012), por exemplo, observam que apesar de as pesquisas apontarem para resultados positivos no que concerne à troca humorada entre enfermeiros e pacientes, o humor ainda é pouco utilizado por esses profissionais, que receiam que sua manifestação seja inapropriada ao setting de cuidados. Igualmente, é possível observar alguns psicoterapeutas que possuem preocupação semelhante, abdicando do humor por medo de não serem levados a sério, ou de perderem o eixo terapêutico das trocas com o paciente (Kuhlman, 1984).

- Maior quantidade e facilidade de acesso a estudos terapêuticos relacionados ao sofrimento e às suas expressões (como o choro), em detrimento de estudos voltados ao humor (e ao riso). Segundo Jacobs (2009), tanto rir como chorar são duas expressões relacionais básicas do ser humano, de modo que deveríamos nos questionar sobre a diferença exorbitante entre trabalhos dedicados à tristeza, ao luto e ao choro, em detrimento de trabalhos dedicados ao humor, ao riso e aos seus mecanismos de coping. Tal predileção se torna ainda mais questionável 
quando compreendemos que estudar o humor não significa se alienar dos processos que configuram nossas dificuldades e sofrimentos, mas apenas compreender outras formas de lidar com os mesmos (Kupermann, 2003; Rutherford, 1994). Contudo, apenas mais recentemente, os autores têm começado a refletir sobre a importância de se discutir sobre o fenômeno do humor nos settings de cuidado à saúde da mesma forma como são discutidos os processos de sofrimento e de recuperação (Assis, 2010; Chazenbalk, 2005; Rutherford, 1994; Tanay et al., 2012).

- Ausência de diálogo entre os estudos já existentes do humor, criando uma visão desarticulada do mesmo. Embora as diferentes áreas que constituem os estudos do humor tomem emprestados conceitos e ideias umas das outras, autores apontam que o diálogo entre as mesmas ainda é incipiente, de modo que tem faltado na literatura o esforço de desenhar conexões acerca dos pressupostos que cada uma delas possui sobre o humor, a fim de gerar uma compreensão mais profunda deste fenômeno (Attardo, 2008; Raskin, 2008). Em outras palavras, ainda é difícil compreendermos do que um determinado autor está tratando quando se refere ao "humor" em seus trabalhos. Tal fato contribui para um preconceito com relação ao mesmo (Koller \& Gryski, 2007; Tanay et al., 2012).

- Ausência de profundidade nos estudos que endereçam as relações entre os processos e as qualidades particulares ao humor e os processos e qualidades particulares à clínica psicoterapêutica. Do mesmo modo que nos estudos gerais do humor, também na literatura voltada à sua presença no contexto da psicoterapia tem existido uma desarticulação, quando não uma superficialidade: a maioria dos trabalhos não se aprofundam no diálogo entre as particularidades do humor e as especificidades da psicoterapia, limitando-se a contar histórias 
sobre seu uso, discutir prós e contras, ou recomendar o que fazer ou não fazer (Kuhlman, 1984; Richman, 2001; Sultanoff, 2013). Por outro lado, quando a discussão é mais aprofundada, os autores tendem a utilizar uma linha ou abordagem psicológica específica, ignorando as contribuições já existentes em outras áreas (Kuhlman, 1984; Kupermann, 2003). Desta forma, este ramo de estudos ainda carece de trabalhos que busquem uma visão mais articulada e compreensiva das possíveis implicações da emergência do humor no relacionamento psicoterapêutico.

- Ausência de proposições que permitam ao psicoterapeuta desenvolver de fato seu senso de humor e suas habilidades humorísticas: embora uma parte significativa dos trabalhos fale da importância de que o psicoterapeuta desenvolva sua capacidade de utilizar intencionalmente o humor na clínica psicológica, a grande maioria não chega a endereçar como este poderia fazê-lo (Franzini, 2001). Grande parte dos autores ignoram as problemáticas envolvidas em tentar criar e direcionar intencionalmente um fenômeno que não é puramente racional e que necessita de uma espontaneidade para acontecer. Por outro lado, aqueles que as endereçam, não propõem saídas possíveis ao problema (Kuhlman, 1984; Rutherford, 1994).

Reconhecendo a importância do humor nas relações humanas e a necessidade de endereçar as dificuldades acima apontadas, o presente trabalho tem como finalidade principal discutir o uso do humor na psicoterapia. Seus objetivos específicos são: compreender os principais processos e qualidades que constituem o fenômeno do humor; refletir sobre o lugar deste fenômeno nas especificidades da prática psicoterapêutica; e apontar possibilidades para que o psicoterapeuta desenvolva maior habilidade e sensibilidade em seu uso. 
Para contemplar tais objetivos, esta dissertação foi organizada em três capítulos.

No primeiro capítulo, exploramos a natureza do humor a fim de compreender os principais processos, qualidades e nuances implicados em sua emergência. Realizamos um passeio histórico pelas diversas formas com que o fenômeno humorado tem sido abordado e compreendido pela humanidade e apresentamos algumas críticas aos estudos mais atuais do humor. A seguir, diante da multiplicidade de concepções encontradas, procuramos esclarecer e justificar o posicionamento desta dissertação com relação a algumas das ambiguidades que surgem entre os diferentes trabalhos. A partir deste esclarecimento, propomos os principais processos e qualidades que constituem o humor - estes foram escolhidos por possuírem a capacidade de explicar características levantadas pelos mais diversos autores, e são quatro: a experiência lúdica; os processos de incongruênciaresolução; o timing do humor; e sua qualidade estética. Por fim, partindo do diálogo e das conexões tecidas ao longo do capítulo, construímos nossa própria definição do fenômeno humorado e apresentamos um quadro (Quadro 4) sobre as principais características que, segundo nossa perspectiva, o constituem. Este, por sua vez, nos instrumentaliza para as discussões do segundo capítulo.

No segundo capítulo discutimos sobre o uso do humor no contexto psicoterapêutico. Para tecermos um diálogo compreensivo entre a psicoterapia e os processos e qualidades particulares do humor (assinalados no capítulo 1), iniciamos o capítulo 2 discutindo sobre os meios, objetivos, processos e condições que, de maneira geral, caracterizam um trabalho psicoterapêutico. Em seguida, refletimos sobre as implicações da emergência do humor na relação terapêutica, segundo cada uma destas particularidades - chamando atenção tanto para os potenciais saudáveis desse surgimento, quanto para possíveis riscos aos quais devemos estar atentos. Por fim, concluímos que acolher o humor na psicoterapia implica mudanças elementares em alguns dos paradigmas da clínica psicológica, mudanças 
estas que contribuem para um empreendimento psicoterapêutico mais saudável. Deste modo, destacamos a importância de que o psicoterapeuta encontre meios de cultivar seu senso de humor.

Nesta direção, o capítulo 3 versa sobre a possibilidade de o psicoterapeuta desenvolver maior habilidade e sensibilidade no uso do humor na psicoterapia. Para tanto, iniciamos problematizando a questão da criação intencional do humor e de como esta seria possível mediante o caráter intersubjetivo, complexo e vivencial do fenômeno humorado o qual impede um controle direto e consciente sobre o mesmo. Em resposta a esta questão, apresentamos a possibilidade de desenvolvimento de um "estado humorado" - o qual não permitiria certezas na criação do humor, mas uma maior sensibilidade e predisposição para propor e se engajar em trocas humoradas. Apontamos como esse estado corresponde a um conhecimento corporificado, que precisa da prática para ser aprendido. Por outro lado, discutimos como a prática profissional do palhaço vem desenvolvendo ferramentas seculares para que o sujeito acesse o estado humorado e estabeleça trocas cômicas profundamente sensíveis e inteligentes com os demais. Nesta direção, discutimos a possibilidade de que os exercícios do treinamento de palhaço ajudem o psicoterapeuta a acessar e desenvolver qualidades, atitudes e estados que possam contribuir para o desenvolvimento do seu senso de humor. Concluímos o capítulo ressaltando que o treinamento de palhaço não pode substituir a importância de se compreender o humor dentro dos processos e qualidade básicos da psicoterapia, mas pode se constituir como uma importante ferramenta a ser integrada no treinamento do psicoterapeuta que deseja desenvolver sua sensibilidade e habilidade humorísticas.

Nosso trabalho conclui que, enquanto há expressões e trocas humoradas pontuais que podem ser utilizadas de forma terapêutica ou iatrogênica, o senso de humor - enquanto uma forma mais geral de se relacionar com a vida - carrega qualidades intrinsecamente 
terapêuticas e fundamentais à saúde humana. Neste sentido, sustentamos que o humor deve integrar o paradigma clínico do mesmo modo que integra nosso cotidiano. Apontamos a importância de que o fenômeno humorado passe a ser abordado na formação dos psicoterapeutas assim como são abordados o sofrimento psíquico e as dificuldades que conduzem o sujeito à terapia. $\mathrm{E}$, por fim, sustentamos a necessidade de mais estudos empíricos que explorem o que foi, aqui, discutido teoricamente. 


\section{Capítulo 1 - "Está rindo do quê?": aproximações aos estudos, à natureza e à prática do humor}

O humor é um dos fenômenos primários da vida humana: como tal, tem se mostrado presente nos mais diversos grupos humanos através dos tempos, diferenciando-se apenas em seus modos de expressão e nos significados de seu uso (Attardo, 2008; Oring, 2008; Tanay et al., 2012). Segundo autores como Raskin (1981) e Tanay et al. (2012), o humor é um potencial inerentemente humano a ser desenvolvido ao longo da vida por meio das experiências. Para Pradita (2010), ele parece estar profundamente ligado ao cotidiano.

Neste sentido, um fato importante é que o humor pode acontecer nas mais diversas situações - dentre elas, na psicoterapia. Essa possibilidade nos remete às seguintes questões: que funções o humor poderia exercer no contexto psicoterapêutico? Poderia ser usado de forma intencional pelo psicoterapeuta ou aconteceria apenas de forma espontânea?

Esses questionamentos são abordados no decorrer desta dissertação. Contudo, neste primeiro capítulo, nosso interesse consiste em discutir o que é o humor - como ele foi compreendido de diferentes formas e que aspectos comuns têm estado presentes nos estudos sobre ele. Nosso intuito com este capítulo é nos instrumentalizarmos para a análise e compreensão acerca do uso do humor nas particularidades da práxis psicoterapêutica, assunto que será abordado no capítulo 2.

\subsection{História do humor}

O termo humor vem dos antigos gregos e, muito antes de associar-se ao cômico em sua utilização, era um termo médico usado para se referir aos quatro fluidos corporais considerados à época: sangue, fleuma, bile negra e bile amarela - os humores. Acreditava- 
se que tais fluidos eram responsáveis pelas patologias, bem como por mudanças nos estados emocionais e comportamentos - daí o surgimento de expressões como "mau humor" e "bom humor" (Ruch, 2008).

O sentido do uso da palavra humor, contudo, transmutou-se: no final do século XVI, o termo humor era utilizado para se referir a um temperamento esquisito, incomum ou excêntrico, que emergia de um desbalanceamento nos fluidos e do qual as pessoas costumavam rir. Aquele que era involuntariamente objeto de riso se tornou conhecido como humorista, e aquele que se deleitava expondo e imitando as peculiaridades de um humorista era um homem de humor.

Entretanto, muito antes da expressão humor ser utilizada com tal sentido, já os antigos filósofos gregos dos séculos IV e V a.C. abordavam o fenômeno do risível dando enfoque ao ridículo como elemento essencial ao mesmo (Menezes, 1974). Aristóteles, por exemplo, defendia o ridículo como um caráter essencial ao cômico ${ }^{2}$, definindo o primeiro como: "defeito ou deformação que não é dolorosa ou destrutiva" (citado por Corrigan, 1981, p. 10). Tanto ele como Platão estabeleceram importantes relações e divergências entre a comédia e a tragédia, diferenciando ambas como atitudes positivas diferentes tomadas diante dos valores humanos (Corrigan, 1981). Tal compreensão, como veremos, influenciou os próximos 20 séculos de teorias sobre o humor (Attardo, 2008).

Desde a contribuição desses filósofos - que se tornaram clássicos no estudo do humor - muitas outras contribuições foram construídas a fim de melhor compreender este fenômeno. A lacuna de estudos na Idade Média é hoje preenchida por um crescente interesse nas ricas manifestações do humor nessa época (Attardo, 2008), como é o caso dos bobos da corte (Neves, 1974). Já na Renascença, por exemplo, Madius realizou um

\footnotetext{
${ }^{2}$ Nesta seção, o cômico será tomado no sentido da linguagem comum e ordinária - referente àquilo que é engraçado - uma vez que autores dessa época desconheciam a distinção, que ficou popular a partir de Freud, entre as expressões: humor, cômico e chiste.
} 
ensaio sobre o humor enfatizando o aspecto da surpresa, negligenciado pelos autores clássicos, e iniciando um interesse pela fisiologia do humor (Attardo, 2008). Enquanto isso, Hobbes abordava o humor como emergindo de uma percepção de superioridade com relação ao outro (Menezes, 1974), visão que ainda hoje é adotada por alguns autores (Manfredi, Adorni, \& Proverbio, 2014).

Séculos depois, Bergson (1903) trouxe suas contribuições ao discutir o riso como função social e o cômico como um fenômeno vivo - não passível de ser encerrado em uma simples definição teórica. Sigmund Freud, por sua vez, destaca-se ainda hoje por sua proposição de distinção entre humor, cômico e chiste, considerando esses fenômenos como emergentes de processos de economia de energia, frutos de uma subversão aos processos esperados da psique (Kupermann, 2003). Nesta mesma direção, diversos autores ao longo da história consideram o humor como resultado de uma incongruência ou contraste entre o que é esperado e o que acaba por acontecer (Menezes, 1974): alguns atribuíram o humor a tensões/expectativas seguidas de um inesperado relaxamento; outros à ativação de esquemas de pensamento opostos em uma mesma expressão (Attardo, 2008; Raskin, 1985); e Fonagy (citado por Zanello, 2005) destacou o próprio jogo vocal antitético que ocorre na entonação e pronúncia do humor.

Em meio a essa diversidade, alguns autores contemporâneos, como Attardo (2008), Menezes (1974) e Raskin (1985), fizeram um esforço de apreensão e classificação, em categorias distintas, das mais diferentes contribuições teóricas sobre o humor. Contudo, esses autores não deixaram de reconhecer que a maioria dos teóricos contempla mais de uma destas categorias. Viktor Raskin, por exemplo, classifica os enfoques dados ao humor ao longo da história em três grupos: teorias da hostilidade, teorias da liberação, e teorias da incongruência (Krikmann, 2006). 
As teorias da hostilidade afirmam essencialmente que a pessoa acha humorado um sentimento de superioridade sobre algo, de poder se sobrepor a algo ou poder agredir um alvo (Attardo, 2008); enquanto as teorias da liberação corresponderiam àquelas que focam majoritariamente no humor como "liberando" alguma forma de energia psíquica e/ou libertando o indivíduo de alguma restrição. Já as teorias da incongruência, de acordo com Krikmann (2006), assumem que cada ato humorado envolve pelo menos uma oposição entre duas diferentes linhas de pensamento - que podem ser chamadas de scripts, estruturas de referência, isotopias, esquemas, entre outros -, formando uma incongruência.

A esta classificação, Menezes (1974) contribui com uma categoria separada para estudos que focam no ridículo como a causa do humor. Já Attardo (2008), acrescenta as abordagens evolucionistas, as quais entenderiam o humor como um mecanismo evolutivo que nos impede de simplesmente seguir um raciocínio incongruente/incoerente, sem perceber sua ilogicidade.

Atualmente, a abordagem psicológica prevalente nos estudos do humor é o modelo incongruência-resolução (Attardo, 2008), o qual compreende a existência de um processo peculiar de produção de sentido (resolução) junto à criação da incongruência. Essa abordagem - hoje em plena construção nos debates, discussões, pesquisas e diálogos acadêmicos - tem se mostrado importante por se aprofundar sistemicamente nos mecanismos e processos particulares ao humor, abrindo novos campos de compreensão e ação com relação a este fenômeno, ao mesmo tempo em que recapitula muitos dos modelos acima sob uma nova ótica (Attardo, 2008; Oring, 2011; Raskin, 2008).

Mesmo com tais avanços, o campo atual de estudos do humor tem sofrido de duas dificuldades principais, as quais ressoam tanto na presente omissão de uma definição clara e consensual do humor quanto na dificuldade de avanço na apreensão de seus processos. 
São elas: a ausência de diálogos e articulações entre estudos, e a dificuldade em assumir e abordar sua qualidade vivencial.

A ausência de diálogos e articulações entre estudos, segundo Attardo (2008), faz-se muito presente na atualidade: malgrado a riqueza histórica de estudos relacionados ao humor e um crescente interesse pelo mesmo em diferentes áreas, falta um "esforço sério de revisão sistemática da pesquisa em cada tradição, quanto mais uma tentativa de integrálas" (p. 131).

Tratar o fenômeno do humor em sua reconhecida complexidade (Hempelmann \& Attardo, 2011; Krikmann, 2006; Menezes, 1974), sem um esforço de diálogo e articulação entre diferentes contribuições, tem provocado sérias consequências ao campo: se, por um lado, o humor é um dos fenômenos menos compreendidos e mais pobremente definidos da realidade social humana; por outro, essa dificuldade de compreensão reverbera em um preconceito com relação ao próprio fenômeno, especialmente na área da saúde: afinal, pode ser perigoso "mexer" com aquilo que a cada momento se apresenta de uma forma diferente e ninguém parece saber do que se trata exatamente (Tanay et al., 2012).

A dificuldade em assumir e abordar sua qualidade vivencial, por sua vez, é muito bem caracterizada por uma frase de E. B. White: "analisar humor é como dissecar um sapo. Poucas pessoas estão interessadas e o sapo morre no processo" (citado por Black, 1959, p. 229).

O humor é uma vivência especificamente humana (Raskin, 1985). Neste sentido, Bergson (1903), ao reconhecer o caráter vivo do humor, destaca a necessidade de um "contato desperto" com o mesmo, em detrimento de uma tentativa de objetificação descaracterizadora. Este contato, segundo o autor, possibilitaria um conhecimento prático e íntimo, muito mais plástico que uma definição teórica encerrada. 
Atualmente, contudo, muitos dos autores que se dedicam à promissora abordagem da incongruência-resolução têm tido como pretensão a criação de programas de computador humorados que reproduzam os mecanismos e processos desenvolvidos nesta abordagem (Attardo, 2008; Hempelmann \& Attardo, 2011; Raskin, 2008). Esses autores acreditam que reduzir os mecanismos do humor a mecanismos de computador os aproxima da verdadeira natureza do mesmo. Entretanto, eles têm encontrado expressivas dificuldades para isso, uma vez que o computador cria apenas aqueles jogos humorados programados pelos seres humanos para acontecer (Attardo, 2008), isto é: o computador em si não sabe o que é engraçado - não tem um sentido de humor - e os processos culturais, sociais, relacionais, simbólicos e emocionais envolvidos neste fenômeno são largamente ignorados pelo mesmo (Hempelmann, 2012; Oring, 2008).

Desconsiderar esses aspectos leva a certos desdobramentos: pouco se tem notícia de quais são as qualidades vivenciais (e não mecânicas) particulares ao humor (Langer, 1964; Kupermann, 2003), bem como das competências práticas envolvidas na vivência dos processos teoricamente desenvolvidos (Attardo, 2008; Kupermann, 2003). De outro modo, particularidades culturais, sociais e individuais acabam sendo ignoradas (Oring, 2008).

Estas questões e dificuldades são importantes para nós, já que queremos saber mais sobre como utilizar o humor na prática psicoterapêutica.

\subsection{Processos e qualidades presentes no humor}

Como pudemos observar na seção anterior, o humor tem sido compreendido de diversas formas e abordado por diversos ângulos. Alguns desses ângulos tratam o humor como algo diferenciado do cômico, do chiste, do riso ou da comédia (Freud, 1905, 1928; Langer, 1953; Oliveira, 2006; Ruch, 2008); outros declaram abertamente que não farão tal diferenciação (Menezes, 1974; Kupermann, 2003); e a grande maioria dos autores aqui 
pesquisados nem sequer considera qualquer diferença (Attardo, 1994; Attardo, 2008; Hempelmann \& Attardo, 2011; Oring, 2008, 2011; Raskin, 1985; Suls, 1983; Tanay et al., 2012).

A distinção mais clara entre o humor, o cômico e o chiste foi realizada por Freud $(1905,1928)$ dentro de sua teoria mais ampla sobre a psique. Kupermann (2003), que se responsabiliza por uma grande revisão das contribuições psicanalíticas para a compreensão do humor, resume essa diferenciação nos seguintes termos:

nos chistes o prazer tem origem na economia na despesa com a inibição que na época está referida ao recalque -, já que a piada é uma manifestação do recalcado que se encontra livre para se expressar. No cômico, o prazer deriva de uma economia de despesa com o investimento em alguma representação que se torna supérflua; (...). Finalmente, no humor o prazer procede de uma economia na despesa com o "sentimento", isto é, com algum afeto desprazeroso que deixamos de experimentar (Kupermann, 2003, p. 40).

Em outras palavras: no cômico, a energia advém de um contraste entre o investimento de energia na ideação ${ }^{3}$ primeira feita pela pessoa ao presenciar algo (diretamente relacionada às suas expectativas) e a energia que é de fato despendida em termos da ideação que acompanha a resolução inesperada do evento. A energia que sobra desta economia é descarregada em forma de prazer cômico (Oliveira, 2008). Já no chiste (ou dito de espírito), a economia se dá ao poupar a energia que é usualmente dispendida no recalcamento de conteúdos inconscientes. No chiste, o jogo de palavras promove um

\footnotetext{
${ }^{3}$ Segundo Oliveira (2008), o conceito de mimetismo ideacional, bem como o de catexia é fundamental para compreender o princípio de "comparação", que se mostra quase que como a base de todo o processo da formação do efeito cômico na mente humana. A catexia diz respeito ao "processo pelo qual a energia libidinal disponível na psique das pessoas é vinculada à representação mental de uma pessoa, ideia, ou coisa, ou investida nesses mesmos conceitos" (p. 159); enquanto o mimetismo diz respeito a movimentos gestuais expressivos que mimetizam o conteúdo da ideação, possibilitando transmitir esta ideação ao outro ainda que não expresso seu conteúdo diretamente em palavras.
} 
"prazer preliminar", infantil, que dá força às intencionalidades inconscientes que ele exprime, permitindo a emergência do processo inconsciente sem o gasto de conflito com o processo de recalcamento - essa economia de despesas resulta numa energia liberada também em forma de prazer cômico (Kupermann, 2003). Por fim, o humor corresponde à economia resultante do sentimento ou afeto que é poupado: no humor, o investimento de energia, que está usualmente no ego, deslocar-se-ia para o superego - o resultado é que para o superego, os interesses do ego e suas preocupações parecem minúsculas e triviais (Freud, 1928). Assim, a pessoa é capaz de "brincar" com aquilo que usualmente seria sofrido, pois consegue transformar suas ocupações aparentemente "sérias" em jogos similares aos de sua infância - quando realiza prazerosamente a reelaboração da realidade (Kupermann, 2003). A economia de energia com o sofrimento usual do qual é poupado, é também descarregada em forma de prazer.

Entretanto, como podemos advertir através das próprias contribuições de Freud (1928) e Kupermann (2003), bem como pelas observações de Oliveira (2008), os três processos acima diferenciados compartilham de muitas semelhanças. Todos os três:

a) Resultam em um prazer cômico através de uma economia de energia;

b) Necessitam, para a ocorrência desta economia, que não haja um excesso de investimento de energia por parte do intelecto ou de um forte afeto $^{4}$;

c) Necessitam de uma razão lúdica para ocorrer, de modo que remetem aos jogos de infância, consistindo numa atualização adulta do brincar;

\footnotetext{
${ }^{4}$ Em outras palavras: caso a pessoa não compreenda de pronto o risível, "pensando demais"; ou caso se comova com aquilo do qual o risível trata, envolvendo-se com outros sentimentos, não há uma economia na energia, que é toda despendida nos processos usuais que a ação ou tema despertam.
} 
d) Não expressam uma perda da realidade, uma vez que, como na brincadeira, essas três formas de cômico mantêm-se atualizadas com relação ao real, em seu jogo.

Além disso, o próprio Freud (1928) afirma compreender o humor e o chiste como formas de expressão do cômico, demonstrando em diversos momentos a fluidez entre esses conceitos (Zanello, 2005); enquanto Kupermann (2003), reconhecendo a diferenciação freudiana, opta por não adotar em seu trabalho uma distinção rígida entre os mesmos três conceitos. Outros autores, como Menezes (1974), também têm se abstido abertamente de qualquer diferenciação entre humor, cômico, chiste e risível.

No que concerne à comédia, por sua vez, a maioria dos autores que a menciona se refere a ela como uma forma de humor (Attardo, 1994; Attardo \& Pickering, 2011). Dos autores aqui abordados, somente Langer (1953) faz uma diferenciação aberta entre estes dois conceitos: comédia e humor. Segundo a autora, o humor pode ter lugar em todos os gêneros da arte, mas tem no drama cômico a sua casa. Na comédia, a estrutura dramática se direciona para um humor que acontece dentro do drama vivido. Em outras palavras, a veia natural da comédia é humorada. Contudo, o humor em si não depende dessa estrutura dramática; ele pode aparecer tanto momentaneamente em outras estruturas artísticas (como é o caso da tragédia ou suspense), quanto de forma irrelevante a qualquer que seja esta estrutura (como é o caso das situações engraçadas cotidianas, das piadas, entre outras).

Por fim, a diferença mais clara e de maior consenso na bibliografia aqui utilizada é entre o humor e o riso: embora alguns autores mais antigos se refiram ao riso como metáfora para o cômico ou humor (Bergson, 1903; Menezes 1974), os autores atuais nem sequer utilizam mais a expressão riso ou risada para se referir a este fenômeno (Attardo, 2008; Kupermann, 2003; Oring, 2008, 2011; Ruch, 2008). A argumentação é a de que a risada pode resultar das mais diversas experiências - inclusive fisiológicas e mecânicas 
(como nas descompensações biológicas e nas conhecidas cócegas) - bem como pode ser forjada se a pessoa identificar a proposta de humor e sentir-se coagida a responder de acordo com a mesma (Ruch, 2008). O humor é apenas uma das causas do riso (Langer, 1953).

Destarte, considerando que os próprios autores que distinguem entre humor, cômico e chiste não se atêm a essa diferenciação, e que muitos autores nem sequer fazem uma distinção no uso das expressões: humorado, cômico, chistoso e risível -, nesta dissertação também não trabalharemos com tal diferença: a literatura que se referir ao cômico, ao chiste ou ao risível será considerada como tratando, de forma mais geral, do fenômeno que aqui chamaremos de humor. A comédia, por sua vez, será entendida como uma das formas estruturais de promover a emergência deste fenômeno, sendo a piada, a pegadinha, os trocadilhos, etc. outras formas "narrativas" do mesmo (Attardo, 1994). Entretanto, como é de consenso na literatura mais recente, e de concordância nossa, o riso ou a risada serão considerados fenômenos diferentes do humor, uma vez que não dependem um do outro para ocorrer.

A diferença entre humor e ironia, por sua vez, merece algumas breves considerações $^{5}$ : nas raras discussões sobre ironia na literatura voltada ao humor, está claro que ambos constituem processos distintos (Attardo, 2008). Kupermann (2003), por exemplo, ressalta que no humor se ri "com a vida" e na ironia se ri "da vida", sendo o "riso" da ironia um riso que parte de uma razão irônica estável e transcendente, ao passo que o "riso" do humor parte da própria celebração do acaso.

Zanello (2009), por outro lado, ressalta a diferenciação proposta por Fonagy em termos da mimese do aparelho fonatório com relação ao gesto que representa: enquanto na

\footnotetext{
${ }^{5}$ Embora Attardo (2008) reforce que esta área específica de interlocução esteja em grande necessidade de atenção por parte dos pesquisadores, ela foge aqui ao escopo do trabalho: os estudos e teorias sobre ironia constituem outro campo próprio de conhecimento; explorá-lo a fim de desenvolver as congruências e diferenças entre tais fenômenos desviaria demasiadamente do problema já complexo que se tem em mãos.
} 
expressão da ironia presencia-se uma forte contração muscular relacionada à expressão de raiva, no humor o que ocorre é uma condensação de jogos vocais opostos, a antítese na própria entonação. Tal diferenciação é audível e atua na relação, de modo que o humor, neste sentido, é mais acolhedor, ao passo que a ironia pode agredir. Contudo, a própria autora ressalta em outro trabalho (Zanello, 2005) que a relação entre o modo de dizer algo por parte do emissor e o modo como este é ressentido pelo ouvinte não é direta. Desta forma, compreendemos que algo humorado pode se tornar ofensivo, e uma ironia não necessariamente ofende.

Attardo (1993), por sua vez, parte da "teoria da menção" para explicar que na expressão da ironia haveria duas enunciações, sendo que uma delas consiste numa menção explícita ou implícita sobre a outra, ridicularizando-a. Já no humor, a incongruência não é necessariamente entre o que se enuncia e a sua "menção", mas entre duas interpretações que se tornam possíveis no enunciado, gerando uma ambiguidade que ao mesmo tempo transmite, inesperadamente, um sentido.

Anos mais tarde, o próprio autor (Attardo, 2008) chama a atenção para a natureza indeterminada e multifuncional tanto do humor como da ironia, de modo que não podemos determinar se serão agressivos ou não, destrutivos ou não, pois tal consequência dependeria do modo como fossem interpretados. Ainda, segundo Saper (1985), no próprio humor pode-se "rir de" ou "rir com", uma vez que se tem o humor como uma ferramenta cujo potencial pode ser utilizado nos mais diversos sentidos.

Existe, portanto, uma inegável gama de diferenciações entre humor e ironia, e, também, uma relativa fluidez entre estes conceitos junto aos autores. Por outro lado, quando tomamos nossas vivências pessoais, é possível relembrarmos de momentos em que presenciamos tanto o uso humorado da ironia, como o acontecimento dela sem qualquer humor. Desta forma, assumimos neste trabalho a visão particular de que o humor e a ironia 
são diferentes, porém não excludentes. Nem todo humor é irônico e nem toda ironia é humorada, mas se a ironia for apresentada na relação de forma coerente com os diferentes processos e qualidades que constituem o humor, como será discutido, nenhuma conclusão pode ser tirada de que a mesma não possa conduzir também à vivência humorística.

Por fim, ao longo da literatura, o humor pôde ser tomado como comportamento social (Bergson, 1903; Menezes, 1974), forma de comunicação (Attardo, 2008; Raskin, 1985; Pradita, 2010), resposta emocional subjetiva (Tanay et al., 2012), processo cognitivo-emocional (Manfredi et al., 2014; Pradita, 2010), processo psicodinâmico (Freud, 1905, 1928; Kupermann, 2003), ato perlocucionário (Attardo \& Pickering, 2011; Zanello, 2009), performance (Oring, 2008), qualidade vivencial (Bergson, 1903), forma de vivenciar e expressar fatos e ideias (Corrigan, 1981; Langer, 1953), habilidade de perceber ou agir (Manfredi et al., 2014; Pradita, 2010; Saper, 1985) e aspecto estético (Saper, 1985).

A partir da leitura desses vários autores, é possível levantar uma série de processos e qualidades comuns presentes no acontecimento do humor, bem como aspectos fundamentais para sua ocorrência. Em termos desses aspectos, pode-se perceber que para ser possível a ocorrência do humor, são necessários alguns pré-requisitos, dos quais podemos destacar três:

1. A existência da linguagem simbólica: o humor é um fenômeno humano ou seja, um computador ou um animal não são capazes de ter humor (Bergson, 1903; Raskin, 1985). Nesse sentido, pressupõe-se uma linguagem simbólica em sua criação - isto é, a capacidade de representar e tornar presente o ausente, através de signos convencionados (Zanello, no prelo).

2. O estabelecimento de uma relação - seja entre duas pessoas; entre uma pessoa e um objeto/situação; ou, ainda, entre a pessoa e ela mesma (através 
da própria capacidade simbólica de deflexão do sujeito sobre si mesmo) (Zanello, no prelo).

3. A promulgação do humor pelo gesto ou pela prosódia. Entende-se aqui o gesto como a capacidade corporal de expressar ideias e sentimentos; e a entonação ou prosódia como gesto incorporado na fala, ou seja, capacidade da fala de também realizar ações, sentimentos e pensamentos (Zanello, 2009). Ambos dizem respeito aos atos perlocucionários: ações realizadas através do uso da linguagem na relação.

Dentre os processos e qualidades particulares do humor, promulgados pelos prérequisitos gerais supracitados, escolhemos apontar aqueles que se destacam não só por seu aparecimento em diferentes trabalhos, mas por sua capacidade de explicar outras características do humor levantadas pelos demais autores. Eles são quatro:

1. A experiência lúdica;

2. A incongruência-resolução;

3. O timing;

4. A qualidade estética.

Uma ressalva importante acerca desses processos se traduz na fala de Hempelmann e Attardo (2011):

Nós afirmamos que nenhum dos mecanismos do humor é único per se ao humor. Os critérios necessários e suficientes ao humor (...) são todos relacionais. Em outras palavras: humor emerge da combinação de "materiais" de outro modo ordinários e não-humorados ${ }^{6}$ (p. 126).

\footnotetext{
${ }^{6}$ Tradução realizada pela autora desta dissertação.
} 
Desta forma, nas próximas seções discutiremos não só algumas das características gerais desses processos e qualidades, mas a forma como se constituem particularmente no humor.

\subsection{O caráter lúdico do humor: a brincadeira}

Entre estudiosos do humor é muito comum uma contraposição entre a ação humorada e a seriedade, identificando a primeira com as brincadeiras. Ruch (2008), por exemplo, caracteriza que para a experiência do humor é necessária uma mudança do estado de seriedade para o estado lúdico - considerando ambos como polos opostos. A sua contraposição do humor à seriedade, por conseguinte, está relacionada à visão do humor como brincadeira e, portanto, algo que trabalha com uma verdade apenas "e se", não transmitindo ou comunicando nada de importante. A seriedade, por sua vez, seria: orientada à tarefa; associada a um estado pensativo e cuidadoso; e apoiada numa estrutura de mente sóbria, serena e desapaixonada. Igualmente, Raskin (1985) considera que uma ocupação séria contradiz a ludicidade que muitos autores associaram com o humor, da mesma forma que Suls (1983) associa o set lúdico do humor com o "não levar a sério". Entretanto, percebe-se que esses autores têm dificuldade - senão se eximem - de discutir o que significam por "sério" e por "brincadeira" para além do uso do senso comum, tratando esta antítese com certa superficialidade. Aventaremos um aprofundamento deste ponto ao longo desta seção, a fim de responder aos questionamentos: ser humorado significa não levar a sério? O que significa considerar o humor como uma brincadeira ou experiência lúdica?

Segundo Huizinga (1950), o lúdico é uma forma de vida absolutamente primária com uma função significante - a entender: possui um sentido em si mesma. Deste modo, a 
qualidade característica das formas de vida que chamamos de "brincadeira" não pode ser reduzida a outras funções - sejam elas lógicas, biológicas ou estéticas.

Porque os animais também brincam, sabemos que suas bases não se encontram no nexus racional (Huizinga, 1950): a diversão, seu elemento essencial, resiste a todas as análises, a todas as interpretações lógicas, e não pode ser reduzida a quaisquer outros conceitos.

Existe, portanto, uma compreensível dificuldade de definição do fenômeno da brincadeira. Contudo, sabemos, por experiência, que o brincar é uma qualidade bem definida de ação que é diferente da vida "ordinária" (Huizinga, 1950): todos nós somos familiarizados com ela, conseguimos distingui-la no cotidiano e podemos descrever algumas de suas características fundamentais. A seguir apresentaremos cinco dessas características, como introduzidas por Huizinga (1950):

1. O jogo/brincadeira é uma atividade voluntária. As pessoas brincam porque se divertem brincando. Caso o sujeito não se engaje na brincadeira, não pode, de fato, se divertir; e caso não se divirta, não pode de fato se engajar. É por isso que a experiência lúdica não pode ser imposta - sua qualidade emergente de diversão pressupõe uma vontade: se feita por obrigatoriedade, deixa de ser uma brincadeira ou jogo para ser uma imitação forçosa dos mesmos.

2. O momento lúdico tem um espaço e tempo próprios bem definidos que se distinguem da vida "ordinária". Isto é: a brincadeira é brincada dentro de certos limites de tempo e espaço definidos pelo seu próprio curso e sentido.

2.1. A delimitação temporal se dá de dois modos. O primeiro corresponde a uma limitação na duração: a brincadeira começa e se brinca para um fim - em seu progresso há movimento, mudança, alternação, sucessão, associação e separação, e em certo momento ela acaba. $\mathrm{O}$ outro se refere à qualidade de repetição no tempo: 
uma vez brincada, ela resiste como criação, constituindo a possibilidade de repetir. Neste sentido, não só a brincadeira como um todo pode ser repetida em diferentes espaços cotidianos e momentos, mas sua estrutura possui elementos de repetição e alternância que viabilizam sua adaptação sem uma descaracterização.

2.2. A delimitação espacial, por sua vez, é o que poderia se considerar como o "playground" demarcado pela brincadeira, seja idealmente, seja materialmente, por deliberação ou como uma questão do curso e andamento da mesma. Esse playground, embora possa envolver algum espaço físico, não se restringe a ele: diz respeito ao caráter da imagem e sua imaginação, engendrando um mundo temporário dedicado à performance de um ato à parte.

3. Nas delimitações acima, as regras têm um papel fundamental: toda brincadeira/jogo tem suas regras. Elas determinam o que sustenta e vigora no mundo temporário circunscrito pelo lúdico. O princípio que as subjaz é o que cria a verdade para este mundo. Portanto, se as regras são transgredidas ou não reconhecidas, a relatividade e fragilidade do mundo da brincadeira são reveladas e ele entra em colapso, de modo que o mundo "ordinário", com seus processos usuais, se reestabelece. Neste sentido, existe a figura do "estraga-prazeres" (nome já bem sugestivo): aquele que não joga o jogo e por isso o "estraga". Este sujeito é diferente do "trapaceiro", dado que o último desobedece a algumas regras do jogo, mas as reconhece e as procura manter vigente, fingindo cumpri-las. O “estraga-prazeres”, independente do motivo pelo qual não joga - seja ele impossibilidade ou discordância - não se engaja nas regras e é acusado por isso.

4. Aqueles que brincam/jogam juntos geralmente tendem a formar um grupo social permanente mesmo depois que o jogo acaba. Não que precisem fundar um “clube", mas o sentimento de "estarem juntos", à parte do resto do mundo - rejeitando as 
normas usuais, criando novas normas e compartilhando algo de importante - cria um sentido de "nós" que se mantém para além do jogo em si.

5. A brincadeira/jogo nos enfeitiça, encanta, ou cativa com sua tensão, intensidade, balanço, contraste, variação, solução, resolução, etc. dentro de uma organização determinada. Esta qualidade de envolvimento, segundo Huizinga (1950), corresponde à experiência estética, à qual dedicaremos uma seção à parte neste capítulo.

No que concerne ao humor, o lúdico é uma condição necessária, porém não suficiente (Raskin, 1985). Se há um consenso entre todos aqueles que escrevem sobre o humor, é que este se constitui como um jogo, uma brincadeira. Segundo Attardo (1993), a ação humorada em um contexto específico carrega implícita ou explicitamente uma metamensagem grosseiramente traduzida como "isto é uma brincadeira", cujo reconhecimento e aceitação por parte daquele que vivencia a ação é fundamental para que a mensagem transmitida no jogo do humor seja compreendida como tal. Da mesma forma, Raskin (1985) afirma que o modo de comunicação humorado é encalçado pelo conceito de brincadeira, o qual todos conhecem e podem naturalmente escolher se engajar ou não.

Suls (1983), por sua vez, alega que a pessoa vivencia o humor em um cenário de jogo, enquanto para Panichelli (2013), uma estrutura de jogo é essencial para a apreciação do humor, pois sem ela o incidente é interpretado de forma totalmente diferente e o divertimento completamente perdido. Também Kupermann (2003), ao destrinchar sobre o humor na lógica freudiana, considera este como uma atividade lúdica que obedece às mesmas leis do brincar infantil - o autor, inclusive, diz ser o humor o exemplo mais bem lapidado de "razão lúdica"7 (p. 91).

\footnotetext{
${ }^{7}$ Designa a imaginação não alienada do mundo social e das trocas relacionais, constitutiva do trabalho psíquico de construção da realidade que opera no jogo infantil.
} 
Tendo em vista as características gerais da brincadeira, acima desenvolvidas, podemos avançar em algumas de suas implicações para a natureza particular do humor. Faremos isso em relação aos cinco pontos supracitados:

1. Todo humor é uma atividade voluntária. Entende-se essa asserção em termos da necessidade de uma disposição do sujeito para a atividade humorada, sem envolver obrigatoriamente uma vontade consciente em produzi-la, uma vez que querer ser engraçado ou achar graça, muitas vezes, paradoxalmente, impede o sujeito de ser humorado. Isso porque se por um lado um grande investimento intelectual ou afetivo prejudica o processo do humor ${ }^{8}$ (Oliveira, 2008; Raskin, 1985), por outro, conhecer o processo intelectual envolvido no humor ou possuir uma vontade de realizá-lo não é garantia de engajar-se nos complexos processos envolvidos no mesmo, uma vez que o humor pressupõe envolvimentos semânticos, emocionais e até mesmo relacionais que não são acessados diretamente pela vontade, intelecto (Suls, 1983) ou pela própria linguagem (Hempelmann, 2012). A vivência do humor pressupõe, portanto, uma certa espontaneidade: é voluntária, mas não necessariamente intencional - não pode ser forçada.

2. O humor tem um espaço e tempo próprios bem definidos que se distinguem da vida “ordinária”. Segundo Kupermann (2003), em sua leitura de Freud, o humor envolve, enquanto fenômeno, um trânsito temporal: o adulto equipara suas ocupações presentes, aparentemente tão sérias, aos seus jogos de criança - podendo se livrar da pesada carga que essas ocupações impõem sem se afugentar nas ilusões. Quanto à possibilidade de

\footnotetext{
${ }^{8}$ Este excesso de investimento intelectual ou afetivo prejudica o humor, tanto se pensarmos neste fenômeno pelo conceito freudiano de investimento de energia, acima discutido, quanto se considerarmos as condições para a existência do humor que serão discutidas mais adiante: o seu caráter de subversão às consequências esperadas dentro dos valores sociais comuns; e a sua qualidade estética específica (em que tudo confirma a possibilidade de mudança e a capacidade da vida de se reinventar). Essas duas condições também prescindem de um "apego" intelectual ou afetivo excessivo a um momento específico.
} 
repetição das brincadeiras humorísticas, Attardo (1994) afirma que os mecanismos específicos de um jogo de humor podem se utilizar dos mais diversos recursos de narrativa, linguagem e alvo, a fim de viabilizar-se em contextos diferentes. Contudo, vale ressaltar que a repetição da piada a uma mesma pessoa não é a mesma coisa que ouvi-la pela primeira vez, dada a importância de seu elemento surpresa (Raskin, 1985).

No que concerne ao espaço, Kupermann (2003) discute que a imaginação presente neste jogo ou brincadeira do humor cria um mundo o qual a pessoa distingue perfeitamente da realidade, mas que, ao mesmo tempo, não se opõe à realidade, e sim reajusta seus elementos de um modo prazeroso: é pela "razão lúdica" que "o sujeito, o mundo dos objetos e a própria realidade são permanentemente reelaborados” (p. 93).

Neste sentido, autores como Attardo (1993, 1994, 2008), Hempelmann (2012) e Raskin (1985) entendem que o humor enquanto brincadeira possui um espaço semântico próprio - compartilha de um princípio cooperativo e de mecanismos semânticos que diferem daqueles subjacentes às demais formas de interação. A próxima seção tratará justamente deste ponto.

3. Nas delimitações de tempo e espaço as regras têm um papel fundamental: todo humor tem suas regras. O humor como uma forma de jogo específica também possui suas regras, e aqueles que não se engajam nelas. Estas regras emergem tanto dos processos particulares ao humor e das condições para que aconteçam; como dos valores, cultura, e subjetividades que constituem o próprio mundo dos sujeitos que brincam.

No último caso, as regras encontram-se implícitas nos sentidos subjetivos, nos processos culturais e sociais, nas formas de relação, nas emoções e nos sentidos físicos emergentes no contexto e atividades da relação. Constituem-se como regras na medida 
em que delimitam tanto o mundo da brincadeira em sentido geral ${ }^{9}$, quanto $o$ que $e$ como cada coisa pode participar do jogo específico do humor. Alguns valores morais ou processos simbólico-emocionais de sofrimento (Corrigan,1981) podem chamar a pessoa de volta ao mundo ordinário porque deixam de compartilhar das transgressões, ideias e experiências que fundamentam a criação deste espaço lúdico humorístico.

4. Aqueles que produzem humor juntos geralmente tendem a formar um grupo social permanente, mesmo depois que a ação humorada acaba. Raskin (1985) afirma que a comunicação humorística, por seu caráter lúdico, só é viabilizada por uma configuração de regras mutuamente acordadas que a tornam uma empresa cooperativa. De modo semelhante, Panichelli (2013) discute que o uso do humor pode permitir a criação e o desenvolvimento de uma forte aliança, pois que possibilita que pessoas diferentes brinquem juntas com uma visão de mundo, o que dá a ambas um senso de compartilhamento e trabalho conjunto.

Contudo, há igualmente a figura do "single-player"10 (Attardo, 2008), que responde pela maior parte das trocas agressivas ou destrutivas do humor. Diz respeito aos jogos de humor que o sujeito joga sozinho, sem considerar o outro, compartilhar ou convidar o mesmo a jogar. Neste sentido, não se está preocupado em brincar com o outro, mas em brincar consigo, e, desta forma, apenas ele se diverte. Pode acontecer também que aqueles que compartilhem dos sentidos, valores e ideias constitutivas da brincadeira possam excluir um outro que não o faça e, portanto, não compartilhe com eles de uma experiência de humor (Attardo, 1993; Suls, 1983).

\footnotetext{
${ }^{9} \mathrm{O}$ mundo de uma casa, por exemplo, possui certas regras configuradas pela cultura e pela subjetividade social, além daquelas pessoais.

${ }^{10}$ Aquele que joga sozinho.
} 
5. Por fim, o humor nos enfeitiça, encanta, ou cativa, não só por seu caráter lúdico de divertimento, mas também:

5.1. Pela característica ambígua particular ao seu jogo, que gera uma tensão constante entre problema e resolução (Hempelmann \& Attardo, 2011; Oring, 2011);

5.2. Por sua qualidade estética única, particularmente envolvente (Langer, 1951).

Ambas as características terão seções particulares para seu aprofundamento neste capítulo. No entanto, adiantamos que nesse encanto se encontra um aspecto poderoso e potencialmente perigoso do humor, uma vez que sua capacidade de envolvimento pode permitir o engajamento e a aceitação de mensagens que, de outro modo, seriam veementemente rejeitadas (Pradita, 2010).

Discutimos até aqui o que significa dizer que o humor é uma experiência lúdica, uma brincadeira ou um jogo. Em nosso pensamento cotidiano, a brincadeira é o oposto direto da seriedade, mas esta relação pode não ser tão simples (Huizinga, 1950). A seguir discutiremos sobre o conceito de seriedade e a sua relação com o fenômeno humorado.

A ideologia da seriedade discutida por Neves (1974) tem sido, segundo esse autor, a maior razão do preconceito com relação ao humor, não só na esfera acadêmica como no cotidiano. Conforme o mesmo autor, a ideologia da seriedade corresponde a regras, formas, normas e padrões que designam o que merece ser tratado por "sério", ao mesmo tempo em que assumem arbitrariamente o status de teoria científica genérica e verdadeira, tornando-se um axioma incontestável.

Essa ideologia considera como "séria" uma atitude de responsabilidade que acesse a realidade - identificando, portanto, "seriedade" com "saber" e "maturidade". Contudo, enquanto a responsabilidade é confundida por esta ideologia com uma postura arrogante e sisuda, o acesso à realidade é confundido com a homologia entre forma e substância, em que a comunicação possui uma identificação direta com aquilo a que se refere. Desta feita, 
as expressões ambíguas, paradoxais e indiretas características do humor, bem como seu caráter lúdico de divertimento o colocam, de fato, numa posição não só de antítese à seriedade, como de desvalia (Neves, 1974).

Entretanto, o autor incita uma postura de contestação a esta ideologia da seriedade. Segundo o mesmo, "se a piada, a observação jocosa em geral, não fosse 'séria', ou seja, se não se referisse acuradamente a fatias da realidade, não haveria riso" (Neves, 1974, p. 36). Começaremos, portanto, pela discussão com relação à realidade.

De acordo com Freud, "a antítese do brincar não é o que é sério, mas o que é real" (Freud, 1907, p. 149). Se por um lado, isto responde diretamente à nossa pergunta sobre a oposição entre humor e seriedade, por outro, nos gera um questionamento sobre sua possível oposição com relação à realidade. Contudo, como já vimos acima, o humor, enquanto um tipo de brincadeira, mantém uma relação profunda com o real.

Neste sentido, Kupermann (2003) aponta para o recorte perigoso da frase acima: no texto original de Freud, o que se segue é uma discussão de que é justamente o fato de a criança distinguir perfeitamente entre o mundo da brincadeira e o mundo real que a possibilita uma conexão de sua brincadeira com a realidade. Além disso, esta distinção entre lúdico e realidade de forma alguma impede o investimento afetivo da criança com o mundo da brincadeira. Conclui Kupermann (2003):

a distinção entre o brincar infantil e a realidade não caracteriza uma oposição, mas revela, de fato, uma conexão através da qual prazer e realidade se fundem e se batem para a criação da subjetividade, do mundo dos objetos e do que vai se conceber finalmente como realidade (pp. 89-90).

De modo semelhante, Huizinga (1950) afirma que a brincadeira não é o mesmo que a vida "ordinária" ou "real", pois se trata de uma esfera de atividades com uma disposição 
própria, como vimos mais acima. Entretanto, isso não significa que a brincadeira se separe completamente da vida cotidiana, pelo contrário: ela é uma parte integral da vida, que a amplia e intensifica por meio de sua função única, além de acompanhá-la por meio dos sentidos que expressa. Huizinga (1950) aponta, inclusive, que a qualidade de "apenas fingimento" do brincar engana a consciência e, paradoxalmente, viabiliza que a brincadeira seja promulgada com "uma absorção, uma devoção que passa ao arrebatamento e temporariamente, pelo menos, abole completamente a questão do 'apenas'. (...) A brincadeira se torna seriedade e a seriedade se torna brincadeira" (p. 8). Neste sentido, o autor enfatiza que o lúdico se encontra fora de antíteses como aquela entre sabedoria e bobeira/estupidez.

Pode-se contestar: o humor se relaciona profundamente com a realidade, mas qual seria a qualidade dessa relação? Seria ela irresponsável e, portanto, não séria?

Em primeiro lugar, em resposta à ideologia da seriedade supracitada, faz-se necessário destacar a arbitrariedade da associação da noção de responsabilidade com aquela de sisudez. O próprio Ruch (2008) menciona em seus estudos a baixa correlatividade entre a "seriedade" e o "mau humor". Esse autor também discute que pessoas consideradas mais sisudas não carecem ou possuem, necessariamente, um menor senso de humor - senão que sua forma de engajamento no mesmo se mostra peculiar e divergente das formas de humor usualmente utilizadas nos testes científicos, os quais se utilizam de certos temas, mensagens e formas de expressão e de narrativa específicos.

Em segundo lugar, naquilo que tange ao conceito de responsabilidade em si, Attardo (1993) postula que uma das funções sociais específicas ao humor é o descomprometimento. Porque o humor é utilizado para transmitir conteúdos sérios implícitos em uma estrutura de brincadeira, sua qualidade particularmente ambígua permite que seja interpretado de maneiras diferentes, admitindo uma flexibilidade 
substancial na comunicação, acompanhada da possibilidade de retratação: "eu só estava brincando". As táticas de descomprometimento do humor no contexto social seriam duas: sondagem e salvamento.

$\mathrm{Na}$ sondagem, a pessoa sonda as reações do outro às ideias transmitidas por ele com sinais abertos de não seriedade: se o outro responder positivamente - rir ou responder com uma forma similar de humor -, o relacionamento social se move em direção a maior intimidade, sem comprometer nenhuma das partes. Contudo, caso alguma das pessoas envolvidas nesta comunicação "leve a sério" a mesma - ou seja, não entre na brincadeira humorada -, pode haver um ressentimento com relação à mensagem, entendendo a brincadeira como uma tentativa de atingir o alvo indiretamente. Neste caso entraria a possibilidade do salvamento: para salvar uma situação que está se tornando socialmente desagradável, a pessoa pode declarar que não tinha qualquer intenção de manter, realizar ou tratar seriamente uma ação que tenha sido iniciada. Desta forma, ainda que o sujeito ofendido ou em desacordo não consiga vivenciar tal gesto como brincadeira, a justificativa acima pode servir para amenizar ou confundir este sujeito quanto à sua interpretação, bem como conseguir o apoio dos demais ("ele não estava falando sério"). Em último caso, coloca a pessoa que não entrou no jogo como a responsável pela interpretação errada e, por conseguinte, pela troca desprazerosa.

Se for tomado somente por esta possibilidade de descomprometimento, podemos alegar que o humor não assume uma postura de responsabilidade e, portanto, é passível de ser desconsiderado como algo sério. Contudo, a possibilidade de sondagem e de salvamento não é absoluta: ainda que a pessoa não se engaje na brincadeira, ela pode compreender o jogo e, portanto, a mensagem que é transmitida (Attardo, 1993). Mais ainda, segundo Attardo (1993) o próprio ato de brincar no humor gera inferências. Desta forma, o reconhecimento da tentativa de brincadeira do sujeito humorista, junto à ausência 
de um engajamento na mesma, pode levar os demais a se questionarem: "que tipo de pessoa brinca com um assunto desses ou dessa forma?". Portanto, podemos afirmar que existe, sim, uma responsabilização pela ação humorada.

Até o momento, desmistificamos em muitos pontos a ideologia da seriedade acima discutida: compreendemos que o humor dialoga com a realidade, que ele não nega a possibilidade de sisudez e que o fato de alguém ser mal-humorado não implica que seja sério ou não. Também entendemos que o uso do humor envolve, sim, uma responsabilização por aquilo que ele promulga. Contudo, resta o questionamento: seria o humor irresponsável justamente pela ação que ele se responsabiliza em promulgar, ou seja, por "brincar com coisas sérias"?

Segundo Corrigan (1983), a seriedade é um valor: "para algo ser sério, nós precisamos atribuí-lo seu valor sério, e isto pode ocorrer somente quando existe um sistema de valores maior o qual aceitamos como válido e do qual um valor específico é uma parte" (p. 10). Em outras palavras, o autor considera que aquilo que é sério se refere diretamente ao sistema de valores que definimos e aceitamos como verdade.

Para Corrigan (1983), o humor não se opõe à seriedade: ele é apenas uma atitude possível com relação a esses valores. Neste sentido, enquanto o trágico lida diretamente com o "sério" (com aquilo que acreditamos ser verdade, bom, bonito, importante), o cômico reconheceria tais valores para, em seguida, superá-los através do que o autor chama de "sorte lógica" ou "oportunismo inteligente": a subversão das deduções que se seguem aos valores instituídos, através da apresentação de uma saída lógica ${ }^{11}$ criativa e inesperada aos mesmos. Esta subversão só é possível, segundo o autor, por um relacionamento mais honesto com a realidade, o que começa com o reconhecimento dos

\footnotetext{
${ }^{11}$ Os diversos autores do humor abordados neste capítulo que utilizam a palavra "lógica" parecem usá-la no sentido do senso comum.
} 
valores pelo que realmente são: valores. "Na comédia o bom senso sempre triunfa" (Corrigan, 1983, p. 9).

No humor, "o eu se nega a sofrer, sem negar o próprio sofrimento" (Zanello, 2005, p. 232). Segundo esta perspectiva, o humor não nega os problemas, sentimentos e expectativas ligadas aos valores, mas "falha" com eles ao apresentar uma lógica surpreendente que deixa aquém a lógica comum dos primeiros (Corrigan, 1983).

Se as consequências sérias - segundo os valores instituídos - são eliciadas de alguma forma (se sofremos, percebemos dor ou dificuldade, ou ainda, se sentimos se tratar de uma ridicularização de algo bonito ou importante), em outras palavras, se não conseguimos compartilhar desta lógica subversiva e "fazer sentido" da mesma, o cômico não acontece. É preciso, portanto, conhecer os limites do sério, reconhecer a seriedade, para sabermos até onde e como podemos brincar com ela.

Desta feita, autores como Menezes (1974) e Kupermann (2003) identificam o fenômeno do humor com a metáfora da dupla face de Janus. Menezes (1974) acrescenta: “com efeito, o cômico apresenta em sua estrutura um caráter eminentemente dialético. Ele inclui em si o trágico e se define dialeticamente por seu intermédio. Nas situações de comicidade, a conduta resultante é uma síntese e uma superação destes contrários” (p. 10). É imprudente, portanto, assumir que o humor não se responsabiliza pelo que é sério apenas por brincar com isto.

Além disso, autores como Langer (1951), Neves (1974) e Saper (1987) ressaltam que o humor pode ser utilizado de diferentes formas e com diferentes intenções. Neste sentido, podemos compreender o humor como um Phármakon: "palavra grega que aponta para a potencialidade de uma substância que pode realizar-se como remédio e como veneno" (Zanello, 2005, p. 221). Há de se considerar, portanto, não só o humor em si, mas a atitude do sujeito que o utiliza, podendo esta ser responsável ou não. 
Como temos visto, a ambiguidade é natural ao humor. Tal fato não parece ser diferente em sua relação com a seriedade. Segundo Corrigan (1983), o humor é aquela linha tênue em que o sério e o absurdo se encontram e, como já dizia Huizinga: "o contraste entre a brincadeira e a seriedade é sempre fluido" (Huizinga, 1950, p. 8). Destarte, podemos encerrar esta seção propondo o Quadro 1, no qual pretendemos explorar a potencialidade do humor para definir-se como "sério", e como "não sério":

\section{Quadro 1}

A compreensão do humor como sério ou como não sério a partir da relação entre o fenômeno do humor e o entendimento sobre a seriedade.

\begin{tabular}{|l|l|} 
Humor como não sério & Humor como sério \\
\hline $\begin{array}{l}\text { "Sério" aqui deve ser compreendido no senso } \\
\text { comum em que seriedade e brincadeira muitas } \\
\text { vezes são consideradas opostas: } \\
\text { "estar brincando" x "falar sério". }\end{array}$ & $\begin{array}{l}\text { "Sério" sendo considerado o próprio caráter } \\
\text { evasivo do humor, que se utiliza justamente deste } \\
\text { sentido de "brincadeira" para transmitir uma } \\
\text { mensagem e promover sua aceitação, sem que os } \\
\text { envolvidos se "comprometam". }\end{array}$ \\
$\begin{array}{l}\text { "Sério" aqui é compreendido na lógica trágica } \\
\text { apresentada por Corrigan (1981) enquanto atitude } \\
\text { de fidelidade e inflexibilidade quanto a sistemas } \\
\text { morais, sociais e pessoais presentes. }\end{array}$ & $\begin{array}{l}\text { "Séria" também deve ser considerada a } \\
\text { possibilidade de superação da lógica trágica - a } \\
\text { oportunidade de fazer frente a estes sistemas } \\
\text { morais e sociais de forma criativa. }\end{array}$ \\
\hline $\begin{array}{l}\text { "Sério" sendo considerado "(..) o senso do que } \\
\text { comportamentos e expressões tradicionais } \\
\text { deveriam fazer e significar" (Oring, 2011, p. 152). }\end{array}$ & $\begin{array}{l}\text { "Sério" tido como o reconhecimento a a } \\
\text { utilização do senso que nós temos do que é real e } \\
\text { importante - ainda que esta utilização seja feita de } \\
\text { forma criativa e inesperada (o que, diga-se de } \\
\text { passagem, é diferente de proposições } \\
\text { "desconectadas da realidade" ou "sem sentido"). }\end{array}$ \\
$\begin{array}{l}\text { "Sério" sendo considerado um estado de } \\
\text { envolvimento com a tarefa (Ruch, 2008), uma vez } \\
\text { que o humor não prescinde de um envolvimento } \\
\text { com a atividade - pelo contrário, pode intensificá- } \\
\text { la, ao mesmo tempo em que, paradoxalmente, } \\
\text { torna ela e a atmosfera que a envolve mais leve e } \\
\text { prazerosa (Kupermann, 2003; Zanello, 2009). }\end{array}$ \\
$\begin{array}{l}\text { "Sério" como compreendendo um estado } \\
\text { pensativo e cuidadoso, apoiado numa estrutura desapaixonada (Ruch, 2008), uma vez que }\end{array}$ \\
$\begin{array}{l}\text { este excesso de intelecto e cuidado impede o } \\
\text { desenvolvimento do humor (Oliveira, 2008; } \\
\text { Raskin, 1985), enquanto este pressupõe o } \\
\text { envolvimento espontâneo (Suls, 1983) e, }\end{array}$
\end{tabular}

Fonte: Elaboração da autora. 2016.

\subsection{O processo “incongruência-resolução" do humor}

Atualmente, a abordagem incongruência-resolução é a abordagem psicológica prevalente nos estudos do humor (Attardo, 2008). Remonta a Aristóteles o entendimento de que o humor emerge do ridículo - uma incongruência não dolorosa ou destrutiva entre 
expectativas socialmente estabelecidas e o que é percebido (Corrigan, 1981). Desde então, a ideia de incongruência como processo fundamental do humor vem sendo desenvolvida direta e indiretamente.

Menezes (1974) afirma que as teorias do humor focadas na incongruência compreendem o cômico como fruto "da percepção de um contraste entre elementos da situação, o qual pode ser racional, natural ou social" (p. 7). Esse autor faz uma retrospectiva de alguns trabalhos que abordaram a incongruência como processo subjacente ao humor: Schopenhauer, por exemplo, acreditava que o cômico seria a inserção da contradição no conceito. Já Herbert Spencer defendeu que o humor não derivaria de qualquer contradição, mas de uma "incongruência descendente" - ou seja, uma contradição que propicie redução da tensão e, consequentemente, uma sensação de prazer; John Willman, por sua vez, discutiu o cômico como ocorrendo quando uma situação gera surpresa ao mesmo tempo que induz uma atitude antagonista de brincadeira ou indiferença.

Também autores já citados em outras seções deste trabalho, como Sigmund Freud e Ivan Fónagy, ainda que não tenham utilizado a palavra "incongruência", enfocaram neste processo: Freud compreendia o risível como uma economia de energia fruto do contraste entre o investimento feito com um sentimento, inibição ou representação, e a despesa de fato gasta com os mesmos (Kupermann, 2003); enquanto Fónagy enfocava na condensação de conteúdos de caráter oposto na prosódia do humor (Zanello, 2009). Por outro lado, autores mais recentes na história do humor, como Raskin (1985), caracterizam o humor como fruto de uma brincadeira de oposição de scripts (esquemas mentais), sobrepondo dois scripts em uma mesma expressão como forma de jogar com sua interpretação.

Como podemos observar logo acima, cada um desses autores, a partir de seu próprio sistema de ideias, abordou o humor como envolvendo um processo de incongruência. 
Alguns deles realizaram também ressalvas quanto à forma específica da incongruência humorada, ressaltando seus desdobramentos: não gerar dor ou sofrimento; ser capaz de reduzir as tensões; ou, ainda, acontecer como brincadeira. Neste sentido, atualmente, muitos autores têm enfocado no caráter específico da resolução da incongruência para que esta seja humorada: no campo da neurolinguística do humor, por exemplo, tem sido comprovada a existência de uma segunda fase no processamento humorístico, posterior à de percepção da incongruência (Attardo, 2008). Enquanto isso, autores da área da linguística cognitiva do humor têm atribuído a esta segunda fase o conceito de "blending"que corresponde à criação de um novo "espaço mental" (domínio/ideia) fora do existente e não necessariamente relacionado a outros espaços mentais (Attardo, 2008).

De forma mais sistemática e expressiva, por sua vez, autores que estudam a semântica e pragmática do humor ressaltam que o que é novo não é a ideia, mas o caminho feito para chegar à mesma. A fim de compreender tais caminhos, esses autores vêm utilizando o conceito de Mecanismo Lógico (LM) ${ }^{12}$ - mecanismo pelo qual a incongruência é ludicamente resolvida e passa a ter sentido (Attardo, 1994; Hempelmann \& Attardo, 2011; Oring, 2011). Em tempo, muitos desses autores passam a considerar o contexto de brincadeira como fundamental para criação de uma resolução particularmente humorística da incongruência (Attardo, 1993; Hempelmann \& Attardo, 2011; Hempelmann, 2012; Kupermann, 2003; Raskin, 1985; Suls, 1983).

Deste modo, a ideia de que o humor emerge não só de uma incongruência, mas de uma forma de resolução peculiar dessa incongruência tem liderado as discussões e os avanços com relação aos mecanismos e processos particulares à produção humorística (Attardo, 2008; Hempelmann, 2012). Estas contribuições são compreendidas como

\footnotetext{
${ }^{12}$ As siglas serão mantidas como no original da língua inglesa, uma vez que é comum entre os autores utilizá-las em referência aos fenômenos. Mantê-la como no original, ao invés de acompanhar a tradução, visa facilitar para os leitores sua identificação em outras literaturas.
} 
avanços à abordagem incongruência-resolução do humor. Dentre as diferentes teorias, discussões e publicações que compartilham desta abordagem, identificamos três entendimentos centrais:

1. A incongruência pode ser tanto causa de horror como de risadas (Corrigan, 1981), não sendo propriamente uma particularidade do cômico: há, portanto, uma forma de incongruência específica cuja resolução possibilita que esta seja humorada.

2. A resolução do humor não consiste em um processo de resolução qualquer. Se por um lado é comum resolvermos incongruências semânticas em um texto sem nem sequer nos darmos conta (Raskin, 1985), por outro, somos capazes de envolver esforço e criatividade para a resolução de incongruências que constituem problemas matemáticos e enigmas sem que tenhamos qualquer experiência humorada (Ruch, 2008). Um importante desafio, portanto, é a compreensão da particularidade do processo de resolução humorado.

3. Esses processos de incongruência e de resolução não se dão de forma linearmente separada. Ainda que alguns autores se refiram a ambos os processos como dois momentos diferentes (Attardo, 1994; Hempelmann \& Attardo, 2011; Raski, 1985), eles dialogam em sua complexidade: uma incongruência sem qualquer tipo de resolução, uma incongruência completamente passível de ser resolvida, ou uma incongruência com uma resolução que não a extingue (caso do humor, como veremos a seguir), consistem em incongruências diferentes (Suls, 1983).

Nesta seção apresentaremos, de forma crítica, as principais contribuições à compreensão do processo de incongruência-resolução característico ao humor, com o intuito de melhor compreendermos as particularidades do jogo humorado segundo as pesquisas e teorias mais recentes. 
Segundo Attardo (2008), a primeira referência na era moderna à abordagem “incongruência-resolução” é de Jerry Suls. Suls (1983) apresenta, em 1972, a ideia de que o humor acontece quando uma pessoa encontra uma incongruência entre duas partes inconsistentes que, por outro lado, se encaixam de uma maneira peculiar, fazendo sentido em algum nível - sendo este processo de fazer sentido o da resolução. Esse autor (Suls, 1983) ressalta que não são apenas os processos cognitivos que estão envolvidos na criação e interpretação da incongruência - também processos cinestésicos, afetivos e emocionais estão articulados com os primeiros e participam ativamente na criação de uma incongruência-resolução engraçada. É dado a isto o fato de que compreender uma piada não garante sua vivência humorada.

Além disso, Suls (1983) também apontou a importância de uma via de assimilação "fantástica" para o humor, a qual seria facilitada por pistas que criassem um set de brincadeira no processamento do mesmo, evitando uma demanda pelo modo usual de resolução de problemas, que visa acabar com a incongruência por completo. Entretanto, Suls, à época, não desenvolveu uma compreensão mais sistemática destas suas ideias, e foi Viktor Raskin, na área da linguística, que realizou tal iniciativa alguns anos mais tarde - a qual foi recebida com sede pelos estudiosos do humor das diversas áreas (Raskin, 2008).

Em 1985, Raskin propõe a SSTH - Semantic-Script Theory of Humor (Teoria ScriptSemântica do Humor), sob o argumento de que todo humor envolve um processo semântico-pragmático, embora cada forma de humor específica possa envolver também outros processos. A SSTH parte de duas premissas:

1. O texto ou situação humorada é compatível com pelo menos dois diferentes scripts que:

1.1. Sobrepõem-se completa ou parcialmente no texto.

1.2. São antônimos locais opostos num sentido especial. 
2. O humor é um modo específico de comunicação não bona fide que possui seu próprio princípio cooperativo distinto daquele desenvolvido por Grice para as comunicações bona fide cotidianas.

A fim de compreender como se dá a primeira premissa, é preciso entender a segunda.

As comunicações bona fide e não bona fide poderiam ser traduzidas como aquelas de boa-fé e de má-fé ${ }^{13}$. A comunicação de boa-fé observa o Princípio Cooperativo de Grice. Considerado por todo aquele que se comunica, esse princípio de cooperação se resumiria ao preceito de que todos os envolvidos numa comunicação estão cooperando para que essa ocorra de acordo com as máximas de verdade, relevância, clareza e suficiência da comunicação para sua compreensão (Pradita, 2010; Raskin, 1985). Essas máximas de cooperação podem ser tanto "flutuadas" - o que significa que uma máxima pode ser ignorada quando em conflito com outra, em favor da comunicação intentada como "violadas".

No caso da violação de uma máxima, o ouvinte percebe uma dificuldade em compreender o que está sendo expresso, mas ainda assumindo uma comunicação de boafé, ele pressupõe o comprometimento com a verdade e relevância do que está sendo dito e busca por uma interpretação menos óbvia (Raskin, 1985). Tal possibilidade nos permite fazer o uso de implicaturas conversacionais (implicar, sugerir ou significar algo diferentemente do que se diz ou expressa literalmente) (Pradita, 2010; Zanello, 2005).

Contudo, se o modo boa-fé é abandonado, e há razões para duvidar que aquilo que o falante expressa seja verdadeiro ou relevante, pressuposições ainda são possíveis, mas o

\footnotetext{
${ }^{13}$ Em latim, bona fide significa, literalmente, "em boa-fé". Contudo, na língua inglesa (língua em que foi proposta a teoria), este é apenas um dos sentidos possíveis à expressão, outros sentidos possíveis seriam: genuíno; real; ou verdadeiro. Dado o contexto em que esta expressão é utilizada na literatura que aqui a propõe, e porque compreendemos (como veremos mais adiante) que o humor é um modo de comunicação genuíno e autêntico - ainda que diferente -, escolhemos por traduzir a expressão bona fide em seu sentido literal de "boa-fé".
} 
valor da comunicação em si é abandonado completamente. Estes são os casos das comunicações de má-fé.

Segundo Raskin (1985), o humor faz parte dos grupos de comunicações feitas de má-fé (junto com as mentiras e as representações teatrais), uma vez que ele:

1. Abandona o compromisso com a verdade: as interpretações que permitem o humor muitas vezes são pautadas em relações impossíveis, irreais ou, no mínimo, incomuns e improváveis ${ }^{14}$.

2. Abandona o compromisso com a clareza: o humor é intencionalmente ambíguo e não tem como pretensão que finalmente se chegue a uma conclusão sobre qual das interpretações estava "correta".

3. Abandona o compromisso com a relevância da comunicação: muitas vezes se expressa só pela diversão da expressão, sem qualquer objetivo de ser relevante.

Tomemos, por exemplo, a frase humorada exemplificada em Attardo (1994): “Clube de Canoagem do Deserto de Gobi”. Esta comunicação em si - como as demais que envolvem o processo de incongruência-resolução do humor - é de má-fé: ela é propositalmente ambígua, não é verdadeira e não contém nenhuma relevância em si; de modo que se fosse tomado o Princípio Cooperativo de Grice, nenhuma implicatura poderia ser tirada e a comunicação seria simplesmente abandonada. Mas não é isso que acontece: $a$ troca humorística ocorre em seus próprios moldes de cooperação (Raskin, 1985), os envolvidos compreendem o jogo estabelecido pela ambiguidade e se divertem com ele (Raskin, 1985; Oring, 2011), e desse jogo emergem sentidos verdadeiros à realidade da troca cotidiana (Attardo, 1993; Hempelmann, 2012; Oring, 2011). O dizer acima, por

\footnotetext{
${ }^{14}$ Como já vimos brevemente, segundo Oring (2011), este "real" ou "verdadeiro" está relacionado ao senso que temos sobre o que sabemos ser verdadeiro e sobre o que as coisas, comportamentos e expressões podem ter, fazer, ser ou significar no cotidiano.
} 
exemplo, ao mesmo tempo em que pode ser engraçado, pode implicar: o caráter "preguiçoso" de quem se diz participar do clube; uma crítica à falta de cuidados a uma região em que antes havia água; ou ainda outra coisa, a depender do contexto. Como veremos mais adiante, o humor não está na fala ou ação em si, mas naquilo que ele expressa no contexto, relação e momento mais amplo.

Deste modo, autores do humor começaram a se questionar acerca de como a comunicação se tornava viável na troca humorada (Attardo, 1993; Krikmann, 2006; Raskin, 1985). A compreensão a que chegaram foi a de que a comunicação específica de má-fé do humor guarda relação profunda com aceitar o convite à brincadeira e entrar em um set lúdico que possui suas próprias regras de troca e sentido e opera numa esfera distinta das regras, espaços, tempos usuais da realidade comum. A seguir, no Quadro 2, encontram-se as regras próprias à comunicação humorada em comparação com aquelas da comunicação de boa-fé ${ }^{15}$ :

\footnotetext{
${ }^{15}$ Apesar de esta ser a posição tanto de Raskin (1985) como de Attardo (1993; 1994; 2008), é questionável a ideia de que o humor seja uma violação do Princípio Cooperativo de Grice. Ainda que a expressão humorada viole algumas de suas máximas, isso não significa que os falantes tenham abandonado a comunicação cooperativa em si, cujo fundamento é: "Faça sua contribuição conversacional tal como requerida, no momento em que ocorre, pelo propósito ou direção do intercâmbio conversacional em que você está engajado" (Grice citado por Zanello, 2005, p. 49). Segundo tal fundamento, as próprias máximas do modo de comunicação particular do humor podem ser consideradas como obedientes a esse princípio, ainda que desobedecendo às máximas conversacionais destacadas.
} 


\section{Quadro 2}

Diferenciação entre os Princípios Cooperativos da comunicação cotidiana e da comunicação humorada a partir da proposição de Raskin (1985)

\begin{tabular}{|c|c|}
\hline $\begin{array}{l}\text { Máximas do Princípio Cooperativo de } \\
\text { Grice (comunicação boa-fé) }\end{array}$ & $\begin{array}{l}\text { Máximas do Princípio Cooperativo do Humor (modo } \\
\text { específico de comunicação de má-fé) }\end{array}$ \\
\hline $\begin{array}{l}\text { Máxima de quantidade: dê exatamente tanta } \\
\text { informação quanto requerida. }\end{array}$ & $\begin{array}{l}\text { Máxima de quantidade: dê exatamente tanta informação } \\
\text { quanto necessária para a comunicação humorada. }\end{array}$ \\
\hline $\begin{array}{l}\text { Máxima de qualidade: diga somente o que } \\
\text { acredita ser verdade. }\end{array}$ & $\begin{array}{l}\text { Máxima de qualidade: diga somente o que é compatível } \\
\text { com o mundo dessa comunicação humorada. }\end{array}$ \\
\hline Máxima de relação: seja relevante. & $\begin{array}{l}\text { Máxima de relação: diga, aja, indique somente o que é } \\
\text { relevante para essa comunicação humorada. }\end{array}$ \\
\hline $\begin{array}{l}\text { Máxima de modo: seja claro (evite } \\
\text { ambiguidades e obscuridades). }\end{array}$ & $\begin{array}{l}\text { Máxima de modo: comunique o humor de forma eficiente: } \\
\text { - Não foque a atenção precisamente na produção } \\
\text { do processo do humor, mas na vivência desse } \\
\text { processo (esta é a diferença entre forçar ser } \\
\text { engraçado e aprender a ser engraçado). } \\
\text { - Considere cada indivíduo e sua relação com o } \\
\text { humor (o humor é muito pessoal). } \\
\text { - Considere a situação em que se produz. } \\
\text { - Esteja engajado nas normas, sentimentos e ideias } \\
\text { do grupo com o qual quer partilhar o humor. } \\
\text { E, levando estes aspectos em consideração, } \\
\text { desenvolva um timing (ver seção seguinte). }\end{array}$ \\
\hline
\end{tabular}

Fonte: Elaboração da autora. 2016.

O set distinto de máximas representado pela segunda coluna do Quadro 2 deve viabilizar, por sua vez, um processo particular do jogo humorado: a sobreposição de duas linhas de pensamento em uma mesma expressão - a chamada Oposição de Script (S. O.).

Segundo Raskin (1985), simplesmente opor duas linhas de pensamento não é condição suficiente para a emergência do humor, uma vez que nem todo texto ambíguo, por exemplo, é engraçado. A Oposição de Script guarda algumas particularidades. Dentre elas, Raskin (1985) ressalta duas:

1. Seus scripts são antônimos locais.

Esses scripts se opõem na forma particular do discurso em que emergem:

1.1 Podem ser antônimos no sentido léxico, em que um é realmente o oposto do outro: 
“- $\mathrm{O}$ acusado tem alguma coisa a mais para oferecer à defesa?

- Não, Vossa Excelência, eu já dei tudo que eu tinha ao advogado, e a alguns dos jurados, que são amigos dele”.

[Scripts opostos (como apontado por Raskin, 1985): justiça X corrupção].

1.2 Podem ser antônimos somente em um discurso particular e somente para o propósito desse discurso - isto é, na vida cotidiana, um não contradiz o outro; mas no discurso, eles se fazem opostos:

"Por que um espelho é como um filósofo?

Porque reflete".

[Scripts opostos: refletir imagem X pensar].

É importante ressaltar que tais scripts podem emergir de informações não implicadas diretamente na expressão, mas disponíveis somente aos sujeitos participantes da troca - o famoso caso das "piadas internas".

2. Esses scripts coexistem pela existência de "gatilhos".

Os gatilhos aparecem direta ou indiretamente na expressão humorada, e o seu papel consiste não numa simples mudança de script, mas em instaurar uma coexistência entre os mesmos, ou seja: ao mesmo tempo em que "dispara" a mudança de um script para o outro, ele torna ambos possíveis, de forma que ainda que um seja mais provável que o outro, não é possível uma resolução completa. Alguns exemplos de gatilhos seriam as polissemias, homonímias ou similaridades fonéticas.

Malgrado a sua importância, o conceito de "gatilho" não foi muito ressaltado por Raskin. Entretanto, pode-se entender que tenha sido o precursor de um conceito-chave para abrir novos caminhos de inteligibilidade ao processo incongruência-resolução do humor (Hempelmann \& Attardo, 2011; Oring, 2011): Os Mecanismos Lógicos (LM). 
Os Mecanismos Lógicos fazem parte da General Theory of Verbal Humor - GTVH (Teoria Geral do Humor Verbal), uma revisão/extensão da SSTH realizada por Attardo e Raskin em 1991. Segundo Attardo (1994), a GTVH intenta considerar não só os aspectos semânticos, como todas as características linguísticas e não linguísticas do humor. Neste sentido, são propostos seis “Recursos de Conhecimento" (Knowledges Resources - KR's):

1) S.O. (Oposição de Script): este conceito é deixado sem mudanças, uma vez que não houve necessidade de abranger seu escopo para dar conta de novos fenômenos. Segundo Attardo (2008), a S.O. remete ao processo de incongruência do humor. Attardo (1994) ressalta que os aspectos específicos que permitem criar a oposição de script - a organização narrativa, a linguagem utilizada, a situação criada, etc. irão variar de acordo com o lugar e tempo de sua produção. Isto parece óbvio, mas traz implicações importantes (Hempelmann \& Attardo, 2011): a fim de se criar uma mesma oposição entre scripts em dois contextos diferentes, pode ser preciso modificar aspectos de sua proposição, ao passo que uma mesma proposição pode criar diferentes oposições de script em contextos diferentes, isto é, um mesmo texto ou gesto pode ser engraçado por motivos diferentes para pessoas diferentes.

2) LM (Mecanismos Lógicos): é o mecanismo pelo qual a incongruência da S.O. é ludicamente resolvida. Ele corresponde à fase de resolução dos modelos incongruência-resolução, mas não consiste somente no resultado, senão no caminho/maneira pela qual os dois sentidos são reunidos, conectando duas coisas que seriam usualmente disparates. Segundo os autores, não só é comum a presença de várias incongruências num texto humorístico (por exemplo, as piadas que só são possíveis porque animais falam), como a própria resolução do humor muitas vezes só é possível por meio de novas incongruências. Estas incongruências são aceitas como parte do caráter lúdico do humor caso possuam um papel na construção do 
mundo humorado - mundo este que, por sua vez, possui como ponto-chave: a construção do processo de incongruência que irá introduzir um mecanismo lógico inesperado para a transmissão da mensagem que se intentava. É por isso que os LM's são tão mandatórios e ao mesmo tempo tão complexos. Hempelmann e Attardo (2011) apontam que não existe fundamento para afirmar que os mecanismos lógicos sejam específicos ao humor, mas que são um dos processos necessários e fundamentais na complexa rede do qual o humor emerge. Nesta, os mecanismos lógicos constituiriam qualidades especiais junto à incongruência, diferenciadas dos mecanismos lógicos que operam em outros processos de resolução - neste sentido, os autores se referem à lógica deste mecanismo como "parcial", "falsa" ou até "ilógica", no sentido de que não resolveria de fato a oposição dos scripts.

3) SI (Situação): a situação corresponde àquilo que constitui os scripts - os objetos, participantes, instrumentos, atividades, etc. - os quais não são engraçados em si, mas cuja armação no texto humorado cria a ambiguidade a ser resolvida de forma não usual. Algumas construções se apoiam nela de forma bem mais direta que outras, algumas trocas humoradas envolvem situações completamente implícitas.

4) TA (Alvo): o que é conhecido como o alvo do humor.

5) NS (Estratégia Narrativa): qualquer texto humorístico deve ser elencado em alguma forma de organização narrativa, seja ela um simples enquadre narrativo, um diálogo (pergunta e resposta), um (pseudo-) enigma, um "a parte” na conversação, etc. Segundo Attardo (1994), a estrutura narrativa é o único parâmetro que precisa ser considerado na correlação ou identidade estrutural entre piadas e outros tipos de texto humorado: uma piada é tida como uma das muitas formas narrativas que o humor pode assumir; logo o mesmo material humorístico pode ser apresentado 
como uma piada, uma anedota, uma pequena história, ou como parte de uma novela. Cada caso irá acarretar diferentes requisitos formais, e estes irão variar de acordo com o contexto de sua construção, ainda que os outros recursos acima não se modifiquem.

6) LA (Linguagem): por fim, corresponde às exatas palavras, ações e expressões de um texto. Grande parte dos textos humorados pode ser expressa de um grande número de formas, a depender do contexto e dos recursos acima, sem mudar seu conteúdo semântico, preservando seu sentido intacto - salvo os trocadilhos, ou os demais tipos de humor cuja "pegadinha" envolva uma palavra ou ação específica. Nesses casos, a linguagem exata é importante para criar a ambiguidade de forma a se conectar com dois sentidos. É por isso que a tradução de algumas piadas se torna impossível, pois um dos sentidos do uso de uma palavra, o qual possibilita o jogo com a ambiguidade, pode não estar disponível no paradigma que constitui o conceito desta palavra em outro país (Wittgenstein, 1991), nem talvez haja conexão análoga que se possa fazer ${ }^{16}$.

Observando as formalizações teóricas viabilizadas pela SSTH e, posteriormente, pela GTVH, fica claro que ambas possuem um importante papel no campo de estudos da natureza do humor, pois partem de contribuições diversas para construir uma compreensão atual e sistematizada acerca dos pré-requisitos, processos e mecanismos próprios a este fenômeno (Attardo, 1994; Raskin, 2008). No entanto, Oring (2011) critica que a ânsia de formalização por parte de ambas as análises acabou levando a um movimento de abstração antes que questões mais próximas da realidade fossem resolvidas.

\footnotetext{
16 Entretanto, o problema que cerca a tradução do humor vai muito mais além, denunciando diferenças
} culturais, sociais, políticas permeadas pela linguagem. Trataremos disto ainda neste capítulo. 
Em outras palavras, é verdade que a GVTH permite gerar um número infinito de textos humorados a partir da combinação de valores de cada um de seus parâmetros (KR's); também é verdade que a oposições de script, os gatilhos e os mecanismos lógicos muito têm contribuído para compreender os processos particulares que subsidiam o humor, mas, sobretudo, é verdade que:

todos [os] ditos de espírito são talhados pelo mesmo modelo. Agora que possuímos a fórmula, podê-lo-emos variar indefinidamente. Mas a arte do contista e do vaudevilista não consiste simplesmente em compor ditos de espírito. O difícil é dar-lhes a sua força de sugestão, quer dizer, torná-los aceitáveis (Bergson, 1903, p. 52).

Neste sentido, Oring (2008) ressalta que é preciso considerar o contexto cultural, social e individual no esforço de interpretação do acontecimento humorado. Contudo, o que se tem observado nos autores da SSTH, GVTH e seus sucessores é uma progressiva ânsia por traduzir em uma lógica linear e de primeira ordem os mecanismos semânticos próprios ao humor (Attardo, 2008; Hempelmann, 2012), ao passo que ignoram cada vez mais a complexidade dos processos emocionais, simbólicos e de sentido engendrados nestes mesmos mecanismos.

É neste embalo que surge o crescente interesse na área computacional do humor: ao tentar reproduzir as oposições de script e os mecanismos lógicos na linguagem computacional, almeja-se que o computador seja capaz de criar e reconhecer autonomamente experiências humoradas - o que, segundo Raskin (2008), atestaria finalmente nosso domínio sobre a ontologia do humor.

Entretanto, Hempelmann (2012), um dos precursores no estudo do humor computacional, esbarrou justamente na limitação supracitada ao procurar avançar nessa 
área de pesquisa. Segundo o autor, o Mecanismo Lógico (LM) “é fácil de ser modelado com sonora similaridade e identidade em um programa de computador, enquanto os efeitos semânticos complexos subjacentes podem ser largamente ignorados” (p. 14). Isto porque, de acordo com o autor, o Mecanismo Lógico é um processo intersubjetivo e, portanto, acontece em uma camada de sentido a qual a linguagem explicitada deixa subespecificada.

A fim de melhor compreendermos a natureza dos mecanismos lógicos do humor, faz-se mister, portanto, compreender do que se trata esta dimensão da linguagem humana mencionada pelo autor, integrando-a à compreensão desses mecanismos. Para tal objetivo, nos utilizaremos de uma leitura wittgensteiniana da linguagem, dialogando-a com as considerações e contribuições de autores do humor como Hempelmann (2012) e Oring (2008; 2011), que vêm avançando numa compreensão mais humana e relacional dos processos humorados.

Wittgenstein (1991) entendia a linguagem como uma parte integral de uma atividade ou forma de vida. Deste modo, propôs a expressão "jogo de linguagem" para se referir ao "conjunto da linguagem e das atividades com as quais está interligada" (p. 12). Segundo esse autor, as significações de uma palavra ou gesto são construídas pelas experiências de vida que permeiam o uso das mesmas. Desta forma, mais do que possuir um sentido linear único, as palavras e gestos são paradigmas: famílias de significações construídas ao longo das experiências com o seu uso. $\mathrm{O}$ autor faz uma comparação entre a palavra, enquanto paradigma, e um fio: um fio possui uma série de fibras trançadas umas com as outras numa rede complexa de semelhanças e diferenças que se entrecruzam mutuamente - o mesmo se dá com as diversas significações de uma palavra. Segundo esta perspectiva da linguagem, não seria possível afirmar que os sentidos e significados de uma palavra ou gesto se encontram claramente separados e linearmente distintos. Por outro lado, se todos os sentidos e significados de uma palavra ou gesto se fizessem presentes ao mesmo tempo e 
indistintamente no momento de seu uso, a linguagem perderia sua função. É, portanto, o uso da palavra ou gesto num jogo de linguagem específico que dá seu significado naquele momento, em detrimento do trançado maior de sentidos que observamos em seus diversos usos. A partir dessa base, podemos avançar em três implicações ao uso do humor:

1. “Quem se admira que se possa saber algo que não se possa dizer" (Wittgeinstein, 1991, p.43). Segundo o autor, nós falamos dos significados e sentidos das palavras como se eles próprios fossem palavras, mas não é bem assim. Como vimos, o significado da palavra é o seu uso, e não outra palavra. Por isso, é possível saber algo quando ninguém nos interroga, mas não saber mais quando transformamos em explicação. $O$ mesmo nos acomete quando somos perguntados: "por que você está rindo? O que tem de engraçado? Qual é a graça?”. Uma vez que o jogo do humor é feito com os sentidos subespecificados da linguagem (Hempelmann, 2012), procurar traduzir seus sentidos em palavras não realiza seu jogo.

2. As expressões: "ilógica", "lógica parcial", ou "lógica falsa", utilizadas para caracterizar e distinguir a lógica desenvolvida pelos mecanismos do humor, são equivocadas. Segundo Wittgeinstein (1991), não existe uma linguagem ideal cuja lógica seja dada no vazio e a partir dela sejam julgadas as demais lógicas desenvolvidas no uso da linguagem: a linguagem só existe no cotidiano e cada comunicação de nossa linguagem é lógica como é. Decorre, portanto, que o humor é uma das formas de jogo com a lógica, isto é, possui um modo particular de desenvolvêla.

Indo por este caminho, Oring (2011) afirma que o humor não é inerentemente ilógico. O que cria este sentido de "ilógico", de "falsidade" é o fato de a lógica humorada subverter a lógica comum, "o senso do que sabemos ser verdade, ou o senso do que os comportamentos e expressões tradicionais deveriam fazer e significar” (Oring, 2011, p. 
152). De acordo com esse autor, o que é incongruente no humor não é o sentido expresso, mas a forma de expressão desse sentido. A incongruência está nas representações linguísticas utilizadas para expressar um sentido - utiliza-se de representações aparentemente remotas dos fatores essenciais que usualmente representam alguma coisa, a fim de representar esta coisa.

Por exemplo: - O que o fósforo falou para o cigarro?

- Por sua causa, perdi a cabeça.

A resposta humorada não deixa de ter sentido, mas quando se fala das representações utilizadas para desenvolver esse sentido, não podemos dizer que elas sejam congruentes com as representações que esperamos pelo contexto colocado (a relação entre fósforo e cigarro), afinal fósforo não tem verdadeiramente a "cabeça" da expressão "perder a cabeça" - o uso de "cabeça" nesta expressão toma um sentido muito pouco material. Mas a lógica construída no uso que se faz da linguagem permite que "cabeça" adquira ambos os sentidos: o sentido do raciocínio e plausibilidade humana e o sentido do local material do fósforo onde o acendemos. Observe que a incongruência desta representação não é resolvida - a ambiguidade entre os dois sentidos se mantém. Contudo, esta incongruência se torna “apropriada" (Oring, 2011) - a contradição entre o uso comum das representações e o uso que está sendo feito é justificada por "fazer sentido".

O que chamamos de Mecanismo Lógico, por sua vez, é esse caminho lógico incomum provocado pela incongruência para chegar à ideia. Segundo Oring (2011), esta lógica surpreendente, em relação aos nossos usos mais comuns da linguagem, é fundamental à experiência do humor. 
3. O jogo de linguagem do humor, assim como os demais jogos de linguagem, é também uma parte de uma atividade ou forma de vida. Por isso, quando uma piada é traduzida, ela pode até ser entendida, mas nem sempre gera a experiência característica do humor. Oring (2008) ilustra isto em artigo sobre o aspecto antropológico do humor: o autor oferece o exemplo de uma piada navarra. Aqueles que não são navarros não conseguem achar graça na piada e, ainda que possam explorar várias ideias que justificariam o cômico - uma vez que entendam aspectos da cultura local -, nenhuma de suas explicações, segundo os navarros, seria o motivo real do porquê a piada é engraçada. Oring então conclui: "mesmo quando uma piada parece completamente compreensível, o contexto sociocultural necessário para apreender sua importação pode estar faltando" (2008, p. 198).

Ao observarmos os tópicos acima acerca do uso humano da linguagem, podemos perceber que o simples reconhecimento dos mecanismos e competências que participam da produção do humor não é suficiente para nos tornar mais proficientes ou receptivos a sua criação. Segundo o próprio Wittgenstein (1991), os jogos de linguagem, assim como outros jogos, possuem regras enraizadas em seu próprio desenvolvimento, mas não se reduzem a elas: as regras de um jogo pouco determinam a forma como este vai se desenvolver efetivamente, como as jogadas serão feitas e o que vai acontecer.

Desta forma, questões relacionadas a como, quando, onde, de quem, para quem implicam significativamente como o humor funciona e o que ele significa (Oring, 2008). A viabilização do humor, portanto, mais do que apenas reproduzir os mecanismos acima requer sensibilidade a estas questões.

Neste sentido, existem certas atitudes humanas subjacentes ao humor as quais devem ser desenvolvidas para viabilizar o engendramento dos processos humorados destacados acima na vida real das relações - o próprio Quadro 2, desenvolvido para 
especificar as condições especiais sob as quais é possível criar o humor, lista algumas destas atitudes. Kupermann (2003) nomeia estas atitudes como "conceitos estéticos" referentes àquilo que não pode ser visto, ouvido ou transmitido a partir de regras claras, mas precisa ser experimentado para ser compreendido. Alguns exemplos destes conceitos, segundo o autor, são: o "tato", a "empatia" e a "ludicidade".

A próxima seção tratará de um conceito estético que tem se destacado entre os autores do humor como competência necessária à sua criação. Posteriormente, adentraremos a qualidade estética geral do humor.

\subsection{O timing do humor}

Quantas vezes nós mesmos não podemos ter feito referência a uma piada, uma ação humorada, ou até mesmo a outro tipo de acontecimento ou performance como "o timing foi perfeito", ou "pra ele faltou timing", ou ainda "perdeu o timing...". Para diversos autores e performers do humor, o timing é um dos processos críticos para sua emergência (Attardo \& Pickering 2011; Raskin, 1985; Suls, 1983).

Mas em que consiste o timing?

Segundo revisão de literatura sobre o timing no humor, feita por Attardo e Pickering (2011), existem três tipos de definições acerca do fenômeno: o timing como distribuição de pausas; como distribuição dos elementos do texto (envolvendo a questão da velocidade e suas variações); ou como interação entre pessoas.

O estudo desses autores (Attardo \& Pickering, 2011) escolheu avaliar as duas primeiras noções de timing no momento de virada do texto humorístico (a chamada 
punchline $e^{17}$ ). Medindo o tempo de pausas e a velocidade em torno deste momento específico em performances humorísticas, não foram encontradas evidências que provassem a existência de uma variação de timing no humor. Entretanto, Attardo e Pickering (2011) escolheram deixar de fora o timing como um aspecto relacional e não foram mais adiante em esclarecer o seu conceito.

No que concerne a este aspecto relacional, Wierzbicka (2010) constrói uma ideia de timing a partir de exemplos de experiências relatadas na Internet sob a expressão "senso de timing". Segundo a autora, "nestes exemplos um artista quer fazer algo na frente de uma plateia, isto é, num lugar particular, num tempo particular. A fim de fazê-lo bem, o artista tem que estar apto a ler a plateia - saber seu estado de espírito, interesses, expectativas correntes, e assim por diante" (p. 283). Poder-se-ia dizer que o senso de timing consiste, portanto, em saber propor no momento "certo" a coisa "certa", em congruência com o momento e os processos particulares presentes.

No que tange especificamente ao processo de incongruência-resolução, Suls (1983) afirma que o timing pode ser crítico. Primeiramente, segundo o autor, é preciso que o tempo na troca humorística não seja tão rápido que dificulte a criação de uma "expectativa usual" a ser surpreendida; nem tão lento que a pessoa antecipe a surpresa (ou se desengaje). Quanto ao processo de resolução, este deve se dar rapidamente ou a experiência humorada é mínima. Talvez este último esteja relacionado ao que os autores afirmam sobre a atividade mental excessiva ser desfavorável ao processo do humor (Oliveira, 2008; Raskin, 1985). Em outras palavras: à ausência de um pronto entendimento lúdico, proporcionado por um timing da brincadeira conjunta, retoma-se a atividade intelectual usual de procura por resolução completa do problema, que se torna intrigante.

\footnotetext{
17 Não há um análogo a esta expressão no português, mas aqui ela pode ser traduzida livremente como "pegadinha": trata-se da ocorrência de uma instância humorada no final do texto disruptiva da narrativa que ela fecha (Attardo, 2008). Nem todo humor envolve uma punchline.
} 
Mas como desenvolver esse timing?

Como temos discutido neste capítulo, identificar se é possível e como propor um jogo humorado dentro de um tempo e espaço subjetivo mutuamente acordado, de modo que o mesmo faça sentido na relação, é uma tarefa demasiadamente complexa e subjetiva para que se possa fazer qualquer intervenção direta e certeira. O que pode ser possível são formas indiretas, atividades, práticas que permitam à pessoa desenvolver um maior engajamento, envolvimento e diálogo com os processos inclusos na criação do jogo do humor numa relação, de modo que fomente maior sensibilidade na criação do mesmo. É neste sentido que o editor Merrit Duff, ao falar sobre cortes de cenas em comédia, afirma que foi na prática com outros profissionais deste ramo que ele desenvolveu um senso de timing: "coming up in that world, I gained a lot of sensibilities, honed my instincts and developed a sense of timing" (Bunish, 2012) ${ }^{18}$.

No mais, a compreensão do que é esse timing humorístico e como desenvolvê-lo ainda é obscura na literatura do humor. Em 1983, Suls apontou a necessidade não só de maiores resultados, como de novas técnicas de pesquisa que nos permitissem identificar se esse elemento poderia satisfatoriamente distinguir um processo humorado de um processo não humorado. Quase 20 anos depois, continua em Attardo e Pickering (2011) a alegação da necessidade de pesquisa sobre o timing na performance do humor, sendo esse um dos tópicos menos estudados nas investigações sobre o humor.

Durante as pesquisas teóricas para a escrita deste capítulo, em julho de 2015, foi realizada uma pesquisa na base de dados da Coordenação de Aperfeiçoamento de Pessoal de Nível Superior (CAPES) e no Google Books sobre os descritores: timing E/AND humor. O único artigo encontrado que se aprofundava no tema foi esse de Attardo e Pickering (2011). Os demais, ainda que contivessem a promessa de falar sobre o mesmo

18 "Chegando naquele mundo, eu ganhei um monte de sensibilidades, afiei meus instintos e desenvolvi um senso de timing” (tradução nossa). 
em seu título, tratavam de outros temas - o timing aparecia apenas em menção ou descrição, mas sem qualquer preocupação de definição ou caracterização. Quanto aos livros, foram encontrados alguns que continham breves discussões ao redor do tema, mas também nenhuma procura em caracterizar e aprofundar no fenômeno.

\subsection{A qualidade estética do humor}

O humor pressupõe uma dimensão estética essencial e indissolúvel (Kupermann, 2003). De acordo com Dewey (2005), a estética diz respeito à experiência de estar envolvido com uma atividade presente de corpo e mente, tomando parte imaginativamente na mesma, a fim de, por meio dela, levar à completude necessidades profundas do nosso ser. Não se trata, portanto, apenas de ideias e representações, mas de um processo que vai a cabo no próprio meio vivido em que a pessoa se encontra no presente - com todas as atividades, linguagens, performances que o permeiam. De forma semelhante, Kupermann, ao falar do caráter estético do humor, utiliza a definição de Elkaim e Stangers (1994): a estética é "a maneira pela qual, antes que formulemos os significados exprimíveis em palavras, o mundo toma sentido para nós de acordo com a maneira pela qual nos afeta e pela qual nós o afetamos" (citado por Kupermann, 2003, p. 31).

Neste sentido, Kupermann (2003) fala do acontecimento estético na relação, fazendo eco à discussão acima sobre a camada de sentido em que os mecanismos lógicos do humor se desenvolvem: esse acontecimento estético, segundo o autor, remeteria a intensidades, sentidos, economias de energia e afetos que não necessitam e talvez mesmo não possam ser representados, apenas indicados pelos efeitos que produzem.

Por sua vez, Dewey (2005) observa que a experiência estética emerge sem qualquer entendimento prévio, e ressalta: "o pensador tem seu momento estético quando suas ideias deixam de ser ideias e se tornam sentidos incorporados em objetos [ações]" (p. 14). Ou 
seja, no pensamento estético, a pessoa pensa no meio qualitativo mesmo em que trabalha; e o saber que emerge do conhecimento estético não só amplia o campo do pensar ou representar, mas implica no aumento de uma potência de agir no mundo (Dewey, 2005; Kupermann, 2003).

O mesmo acontece com o humor. A emergência de sua experiência é algo que pode ser constatado empiricamente (vivenciado), porém não dedutível logicamente: o humor só se faz presente quando é vivido de fato. Assim, os processos e sentidos do humor são produzidos na experiência do humor. Talvez seja isto que tenha impulsionado o próprio Raskin (1985) a afirmar: todo mundo "tem" o humor em certo grau, pois quem não "tem" humor, não consegue se comunicar deste modo.

Nada mais plausível então que deduzir que o humor é um acontecimento de sorte, o qual não se pode desenvolver e aprender a ter certa intenção sobre. Ora, mas a arte não demonstra justamente o contrário? Só porque não há respostas simples e fechadas, não significa que não há respostas (Morin, 2005a), mas é preciso nos conformarmos que talvez as encontremos em outro nível que não necessariamente possa ser contemplado em palavras, códigos, quiçá instruções, senão na própria prática em que a experiência estética se encontra incorporada.

Neste sentido, Kupermann (2003) entende que o paradigma estético se aproxima do problema ontológico mais geral da maneira pela qual nos situamos no mundo e situamos as coisas em relação a nós, mas encontra sua representação na criação artística. De outro modo, também Dewey (2005) ressalta que os trabalhos artísticos são formas intensificadas e refinadas da experiência estética cotidiana. Contudo, este último autor ressalta que o potencial desse saber artístico e os próprios artistas têm sido banalizados pela mudança estrutural de pensamento da sociedade ocidental que aconteceu na Revolução Industrial: o 
pensamento de reprodução e mecanização não se interessa por artistas, uma vez que esses não podem trabalhar mecanicamente, dada a própria natureza de seu trabalho.

Não obstante, é possível vislumbrarmos mais claramente o caráter estético particular do humor por meio da comédia, uma vez que, embora o humor tenha lugar em todas as artes, podendo haver momentos de humor nos mais diversos gêneros dramáticos, ele tem no drama cômico a sua casa (Langer, 1953). A estética particular do cômico pode ser compreendida pela seguinte afirmação de Corrigan (1981):

Toda comédia celebra a capacidade humana de suportar, dramatiza o fato de que não importa quantas vezes nós podemos ser derrubados ou ficar aquém, nós de alguma forma conseguimos nos levantar e seguir caminhando. Há algo quase biológico sobre a comédia (...). Ela revela a inextinguível vitalidade do nosso próprio impulso de sobreviver. A intuição central da comédia é uma inata e profundamente sentida confiança na vida. Apesar dos muitos fracassos que nós podemos e, de fato, experimentamos - nosso destino trágico -, o espírito cômico expressa exaltação sobre nossa condição porque está tão supremamente consciente da maneira como a vida prossegue, das muitas maneiras que continuamente se afirma (p. 8).

A fim de ajudar a esclarecer ainda mais a particularidade da experiência estética cômica, desenvolvemos aqui o Quadro 3, que parte das comparações de Langer (1953) entre a forma básica de se situar no mundo subjacente à estrutura da comédia e a forma básica de se situar no mundo através da tragédia. 


\section{Quadro 3}

Divergências estéticas entre a comédia e tragédia a partir da perspectiva de Langer (1951).

\begin{tabular}{|l|l|}
\hline Comédia & Tragédia \\
\hline $\begin{array}{l}\text { Sentimento subjacente: puro sentido de vida; } \\
\text { senciência. }\end{array}$ & $\begin{array}{l}\text { Sentimento subjacente: sentido de crescimento; } \\
\text { presciência }\end{array}$ \\
\hline Destino: fortuna que se desenvolve nas ações. & $\begin{array}{l}\text { Destino: fatalidade como futuro moldado } \\
\text { antecipadamente. }\end{array}$ \\
\hline $\begin{array}{l}\text { Essencialmente contingente, episódica e étnica - } \\
\text { todas as criaturas vivem pelas oportunidades, em } \\
\text { um mundo cheio de desastres. }\end{array}$ & $\begin{array}{l}\text { Forma fechada, final, passional e individual - no } \\
\text { percurso de cada um, as fases da vida são } \\
\text { potenciais para crescimento físico, mental, moral e } \\
\text { pessoal. }\end{array}$ \\
\hline $\begin{array}{l}\text { Suas lutas com o mundo não o exaurem e, de fato, } \\
\text { dificilmente valem recordar: vive-se pelo } \\
\text { momento, logo tais lutas fazem parte do constante } \\
\text { ritmo entre a perturbação e um novo equilíbrio } \\
\text { realizado por meio de um oportunismo inteligente. } \\
\text { Não há uma mudança de caráter essencial, apenas } \\
\text { uma adaptação daquele que é. }\end{array}$ & $\begin{array}{l}\text { Grandes conflitos morais, sacrifícios e fatos que } \\
\text { determinam seu futuro e por isso se encontram } \\
\text { presentes ao longo de sua história: vive-se pela } \\
\text { história, logo suas lutas fazem parte de uma } \\
\text { carreira pessoal para seu desenvolvimento e } \\
\text { mudanças essenciais. Os acontecimentos que se } \\
\text { somam à sua história o modificam } \\
\text { substancialmente. }\end{array}$ \\
\hline
\end{tabular}

Fonte: Elaboração da autora. 2016.

Na relação entre o humor e a comédia, é importante notar que o humor pode se dar pontualmente, como o que Langer (1953) chama de "emoção diretamente estimulada", no sentido que não precisa se relacionar com uma estrutura maior de proposição: pode ser uma piada qualquer, ou uma situação inusitada, como alguém tropeçando. Mas na comédia, este humor não é um subproduto, senão possui um caráter estrutural. Ele se apresentaria, segundo a autora, como "emoção simbolicamente apresentada": o que é engraçado não é uma ação isolada, mas o papel que ela toma no jogo em que estamos envolvidos. Ambos concretizam a diferença entre contar qualquer tipo de piada que seja engraçada para que a pessoa vivencie o humor e construir uma situação humorada junto à situação que está se apresentando no momento. Nota-se que não é a experiência estética humorada que varia - o sentido incorporado na atividade é o mesmo, mas a forma como ele se desenvolve na experiência é diferente.

Do mesmo modo, a estética do humor não implica que ele seja sempre uma ação saudável, terapêutica ou positiva. Já discutimos neste trabalho sobre isto, mas é preciso 
retomar, pois que as considerações logo acima podem trazer equívocos: sob a forma do humor podem-se ter muitas atitudes - ela pode ser utilizada para diversos propósitos e para transmitir diversas mensagens; pode, inclusive, aproximar a pessoa ou afastá-la do contato com suas questões pessoais.

\subsection{O que vimos até agora?}

A partir da explicitação dos processos presentes no humor, pudemos erigir o Quadro 4, no sentido de nos instrumentalizar para a compreensão da ocorrência do humor na práxis psicoterapêutica, tema do segundo capítulo.

Quadro 4

Resumo da compreensão desenvolvida no Capítulo 1 sobre os processos e qualidades centrais na constituição do fenômeno humorado.

\begin{tabular}{|c|c|c|}
\hline $\begin{array}{l}\text { Processos e qualidades } \\
\text { essenciais ao humor }\end{array}$ & Aspectos principais & Implicações \\
\hline Lúdico (ou brincadeira). & $\begin{array}{l}\text { - Pressupõe espontaneidade. } \\
\text { Possui um espaço e tempo próprios } \\
\text { que não se opõem à realidade, mas a } \\
\text { ajustam de modo prazeroso. } \\
\text { - } \quad \text { Tem suas regras. } \\
\text { - Aqueles que produzem humor juntos } \\
\text { (rir com) tendem a formar um grupo. } \\
\text { Existe aquele que joga sozinho sem } \\
\text { considerar o outro (rir de). } \\
\text { O humor encanta por seu caráter } \\
\text { lúdico, seu jogo particular de tensão } \\
\text { constante entre problema e resolução, } \\
\text { bem como por sua qualidade estética } \\
\text { essencial. }\end{array}$ & 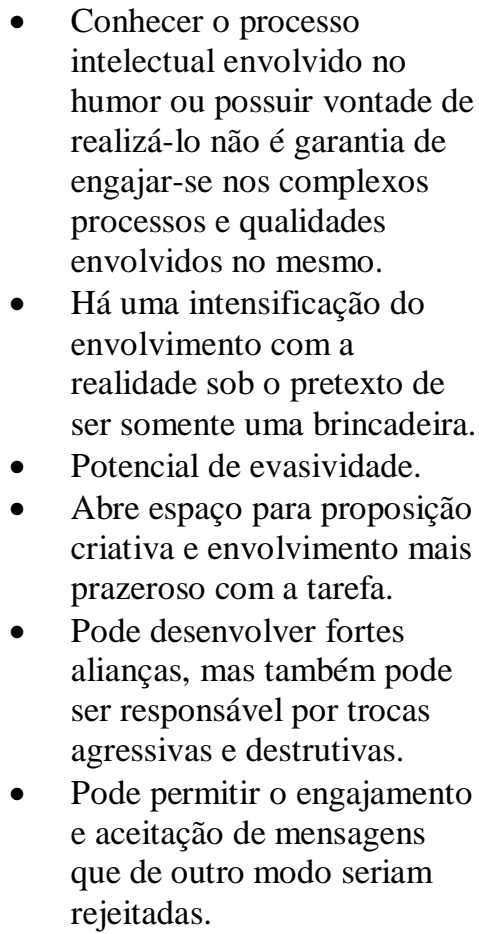 \\
\hline
\end{tabular}




\begin{tabular}{|c|c|c|}
\hline $\begin{array}{l}\text { Processos e qualidades } \\
\text { essenciais ao humor }\end{array}$ & Aspectos principais & Implicações \\
\hline $\begin{array}{l}\text { Incongruência- } \\
\text { Resolução. } \\
\text { Emerge de dois } \\
\text { processos } \\
\text { interdependentes, porém } \\
\text { que não se esgotam um } \\
\text { no outro: a Oposição de } \\
\text { Script e os Mecanismos } \\
\text { Lógicos. }\end{array}$ & $\begin{array}{l}\text { - O processo incongruência-resolução só } \\
\text { é constituído através de um princípio } \\
\text { cooperativo próprio ao humor, que } \\
\text { pressupõe a entrada num universo } \\
\text { lúdico. } \\
\text { - Oposição de script: linhas de } \\
\text { pensamento que se sobrepõem } \\
\text { completa ou parcialmente na expressão } \\
\text { e que coexistem pela existência de } \\
\text { "gatilhos" (isto é: Mecanismos } \\
\text { Lógicos) } \\
\text { Mecanismo Lógico: caminho lógico } \\
\text { incomum (sentido inesperado) através } \\
\text { do qual linhas de pensamento } \\
\text { usualmente disparates são conectadas, } \\
\text { "fazendo sentido". } \\
\text { O humor emerge do modo } \\
\text { surpreendente pelo qual um sentido é } \\
\text { expresso, pela sua lógica inesperada } \\
\text { diante do senso comum que já temos } \\
\text { do que as coisas devem fazer e } \\
\text { significar. } \\
\text { É engendrado nos processos culturais, } \\
\text { sociais, individuais, relacionais, } \\
\text { simbólicos e emocionais permeados } \\
\text { pela linguagem. }\end{array}$ & $\begin{array}{l}\text { O humor reconhece o } \\
\text { sistema de valores vigente } \\
\text { para em seguida subverter } \\
\text { sua lógica através de uma } \\
\text { saída lógica criativa - } \\
\text { criando novas e diferentes } \\
\text { conexões entre linhas de } \\
\text { pensamento comuns. } \\
\text { - Não nega problemas, } \\
\text { sentimentos e expectativas } \\
\text { ligadas àquilo que valoramos } \\
\text { como importante. Mas } \\
\text { dialoga com eles para saber } \\
\text { se é possível e como } \\
\text { subvertê-los. } \\
\text { Criatividade. } \\
\text { - Quebra de expectativa. } \\
\text { - Sentido de liberação de } \\
\text { restrições. }\end{array}$ \\
\hline Timing & $\begin{array}{l}\text { - Propor no momento "certo" a coisa } \\
\text { "certa", em congruência com o } \\
\text { momento e os processos particulares } \\
\text { presentes. } \\
\text { Processo de incongruência não pode } \\
\text { ser nem tão rápido que dificulte criar } \\
\text { expectativa, nem tão lento que a } \\
\text { pessoa antecipe a surpresa ou } \\
\text { desengaje, e caso o processo de } \\
\text { resolução demore muito é retomado o } \\
\text { molde de resolução cotidiana de } \\
\text { problemas. } \\
\text { *escassez de pesquisas neste campo. }\end{array}$ & $\begin{array}{l}\text { O timing humorado é } \\
\text { demasiadamente complexo e } \\
\text { subjetivo para qualquer } \\
\text { intervenção direta: } \\
\text { necessidade de formas } \\
\text { indiretas, atividades e } \\
\text { práticas que permitam } \\
\text { desenvolver um maior } \\
\text { engajamento, envolvimento } \\
\text { e diálogo com os processos } \\
\text { envolvidos no jogo } \\
\text { humorístico. }\end{array}$ \\
\hline Estética & $\begin{array}{l}\text { - Não se reduz a ideias ou } \\
\text { representações, mas remete a um } \\
\text { processo que vai a cabo no meio } \\
\text { vivido. } \\
\text { - Possui sentidos específicos } \\
\text { incorporados à forma de sua atividade: } \\
\text { senciência e celebração da capacidade } \\
\text { da vida se reinventar. } \\
\text { - Vivência "engraçada". }\end{array}$ & $\begin{array}{l}\text { O humor só se faz presente } \\
\text { quando é vivido de fato: os } \\
\text { processos e sentidos do } \\
\text { humor são vividos na } \\
\text { experiência humorada. } \\
\text { Desafia a pretensão de } \\
\text { interpretação linear e } \\
\text { tecnicização. } \\
\text { A vivência humorada pode } \\
\text { ser utilizada com diversos } \\
\text { propósitos e pode ter em sua } \\
\text { constituição ideias muito } \\
\text { diferentes. Logo o humor } \\
\text { não tem uma valoração } \\
\text { inerentemente positiva ou } \\
\text { negativa. }\end{array}$ \\
\hline
\end{tabular}

Fonte: Elaboração da autora. 2016. 
Além disso, faz-se mister destacar, a partir da diversidade teórica estudada, a construção de uma definição sobre o humor a partir dessas leituras. Neste trabalho, tomaremos o humor como uma qualidade bem definida de ação, cujo elemento essencial é a vivência engraçada. Essa vivência emerge no contexto lúdico da brincadeira humorada, a qual envolve a criação de uma lógica inesperada que se utiliza, de forma incomum, do senso comum (que já temos) sobre o que as coisas devem fazer e significar, unindo linhas de pensamento usualmente disparates. Esta lógica surpreende-nos por possuir sentidos pertinentes a nossa realidade, ainda que seu modo de expressão seja subversivo à forma como usualmente nos colocamos diante do mundo e das situações.

Como qualquer jogo ou brincadeira, o humor possui suas regras específicas que viabilizam este processo, algumas das quais:

- Não foque a atenção precisamente na produção do processo do humor: a preocupação em ser engraçado impede a vivência espontânea inerente ao seu jogo.

- Não pode haver um excesso de investimento intelectual ou afetivo em sua proposição (se nela houver algo que aborreça alguém, que evoque um problema, ou desperte uma forte emoção, perde-se o potencial de subversão).

- É importante considerar cada indivíduo e sua relação com o humor (o humor é muito pessoal).

- É necessário estar engajado nas normas, sentimentos e ideias do grupo com o qual quer partilhar o humor;

- E, levando os aspectos acima em consideração, o timing é fundamental.

Por tudo isso, a vivência do humor carrega um sentido especial de prontidão a todo momento para reinventar-se numa atitude sincera com a vida. 


\subsection{Considerações finais}

Este primeiro capítulo teve por objetivo compreender os processos e características essenciais ao fenômeno do humor.

A partir da revisão de literatura realizada compreende-se que o modo especial de comunicação desenvolvido na experiência do humor inclui:

- Um enquadre lúdico: de qualidade profundamente estética, a brincadeira é a sua própria finalidade, inclusive quando comporta atividades utilitárias outras (Huizinga, 1950; Morin, 2005b). Ela permite a saída de uma vida ordinária para entrada conjunta, por aqueles que participam dela, num universo subjuntivo com espaço e tempo definidos, delimitados em suas próprias regras. Tal fato conduz a uma tendência a conotar pejorativamente a lógica lúdica que lá se desenvolve como "falsa", "ilusória" e até “ilógica". Contudo, paradoxalmente, é esta peculiaridade do universo lúdico que permite que a pessoa se envolva com processos e proposições tão profundamente quanto não é possível por meio das proposições cotidianas. Isto lega ao humor uma característica encantatória e potencialmente perigosa, induzindo-nos a aceitar pensamentos subjacentes que se colocados de maneira usual rejeitaríamos.

- Um timing: desenvolvido na interação, corresponde a um senso subjetivo do momento e forma de proposição, ainda pouco explorado na literatura.

- Um processo de incongruência-resolução viabilizado pelas duas particularidades acima e caracterizado, especialmente: 
- Pela criação de dois scripts opostos numa mesma comunicação: um que é comumente desenvolvido no uso cotidiano das representações e outro que é inesperado.

- Pelos mecanismos lógicos que tecem caminhos surpreendentes e não usuais - envolvendo processos emocionais, simbólicos, subjetivos, linguísticos, físicos, fisiológicos, pessoais e sociais apresentando uma lógica que dá sentido a esta oposição de scripts sem resolver sua ambiguidade.

- Uma qualidade estética: na estética, as ideias e pensamentos se fazem no meio qualitativo mesmo em que atuam; em outras palavras, são sentidos incorporados em objetos e ações que os realizam. Desta forma, as experiências estéticas não são passíveis de representação explícita, senão de vivência e constatação. Assim acontece com o humor: seus processos e sentidos se articulam na própria experiência do humor e acontecem por meio dela. $\mathrm{O}$ sentido mais profundo que o humor realiza em sua atividade, ou seja, a experiência estética do humor, pode ser traduzido como: uma celebração da capacidade da vida de se reinventar, em que emerge um sentimento de "graça” (Corrigan, 1981).

Ademais, ainda que a experiência do humor em si seja universal, aquilo que permite desenvolver a sua forma - o que é utilizado para viabilizá-la enquanto jogo específico num determinado momento - irá depender de processos sociais, culturais, relacionais, situacionais e, inclusive, idiossincráticos (Hempelmann, 2012; Oring, 2008; Raskin, 1985).

Tomando as duas principais dificuldades atuais no estudo do humor respectivamente: a ausência de diálogos e articulações entre as áreas, e a notória omissão em assumir e abordar sua qualidade vivencial - este capítulo objetivou articular, em uma 
visão crítica, coerente e vivencial, as principais ideias desenvolvidas até o momento acerca do fenômeno humorado. Tal esforço tem como propósito possibilitar uma visão mais compreensiva do fenômeno do humor e construir um solo fecundo para os nossos dois próximos capítulos. 


\section{Capítulo 2 - "Rir é o melhor remédio"?: Aproximações às implicações do uso do humor na psicoterapia}

O reconhecimento do potencial terapêutico do humor vem crescendo consideravelmente desde o século passado (Kuhlman, 1984; Saper, 1987; Sultanoff, 2013). Atualmente, publicações de diversas áreas da saúde demonstram concordância quanto aos benefícios do uso do humor como ferramenta terapêutica (Cai et al., 2014; Koller \& Gryski, 2007; Panichelli, 2013; Tanay et al., 2012).

Autores como Chazenbalk (2005), Saper (1987) e Sultanoff (2013), ao realizarem revisões de literatura sobre o tema, ressaltaram o amplo potencial do humor para promover mudanças, uma vez que a experiência humorada envolve de forma integrada diferentes áreas da existência humana, tais como: fisiologia, emoção, cognição, comportamento e interações sociais.

Entre os benefícios fisiológicos do humor apontados pela literatura estão a liberação de endorfina, a diminuição da pressão arterial, o relaxamento da tensão muscular, a regularização da frequência cardíaca e do processo digestivo, e o aumento do nível de anticorpos (Chazenbalk, 2005; Sultanoff, 2013).

Já em termos emocionais, é possível observar: reduções nos níveis de depressão e ansiedade (Cai et al., 2014; Rutherford, 1994), elevação emocional espontânea e consequente alívio de sentimentos como angústia e raiva (Sultanoff, 2013), aumento do senso de humor, bem como do sentimento de esperança (Cai et al., 2014), de afeto e de apoio (Chazenbalk, 2005).

O humor também é frequentemente associado não só à criatividade, à inteligência e ao contato com a realidade (Rutherford, 1994), como à possibilidade de desvio de foco 
(Cai et al., 2014; Chazenbalk, 2005), autodistanciamento e produção de insights (Kuhlman, 1984; Richman, 1996; Rutherford, 1994).

A literatura ainda aponta importantes benefícios sociais no uso do humor, sendo alguns deles: o favorecimento de uma relação mais próxima ou o aprofundamento da mesma (Chazenbalk, 2005; Sultanoff, 2013); a emergência de um sentido de conexão com os outros (Sultanoff, 2013); o potencial de suavizar uma discussão que de outra forma seria muito intensa para ser produtiva (Rutherford, 1994); a melhoria de desempenho no trabalho (Chazenbalk, 2005; Sultanoff, 2013); e a construção de uma atmosfera leve na relação (Zanello, 2005).

No contexto destes achados, é natural que comecemos a nos questionar sobre o lugar que o humor ocupa na clínica psicológica. Embora o uso do humor na psicoterapia possa remontar ao período do surgimento da mesma, foi somente a partir da década de 1970 que presenciamos uma maior quantidade de trabalhos voltados ao tema (Saper, 1987). Segundo Kuhlman (1984), tal emergência acompanha o aumento de abordagens psicológicas e o início de um movimento de ecletismo e integração entre as mesmas, configurando uma atitude menos positivista e dogmática com relação à práxis psicoterapêutica. É também nesta época que ocorre uma mudança de paradigma na psicologia: o foco primário na patologia começa a ceder lugar a um interesse progressivo nos aspectos saudáveis do ser humano (Chazenbalk, 2005).

Desta forma, um crescente número de psicoterapeutas passou a relatar o uso do humor em sua clínica e advogar em favor do mesmo em seus relatos de caso, escritos e estudos (Kuhlman, 1984; Saper, 1987). Segundo esses trabalhos, o uso do humor na psicoterapia possibilitaria, dentre outras coisas: "brincar" com os acontecimentos de vida viabilizando empoderamento sobre situações pessoais e manejo da ansiedade (Kuhlman, 1984; Prerost, 1984); viabilizar uma saída terapêutica para expressão de impulsos (Prerost, 
1984); lidar com as resistências e "driblar" mecanismos de defesa do paciente (Chazenbalk, 2005; Kuhlman, 1984; Rutherford, 1994); promover distanciamento, perspectiva, novos insights e formas de perceber e se relacionar com o mundo (Kuhlman, 1984; Kupermann, 2004; Smith, 1973; Sultanoff, 2013); facilitar o vínculo terapêutico (Chazenbalk, 2005; Panichelli, 2013; Sultanoff, 2013); criar um contexto de liberdade de expressão (Chazenbalk, 2005); bem como intervir em diferentes camadas de sentido simultaneamente - possibilitando ao terapeuta endereçar paradoxos e duplo-vínculos (Kuhlman, 1984; Panichelli, 2013), e acessar processos inconscientes não acessíveis diretamente pela lógica discursiva (Erickson \& Rossi, 1979; Richman, 1996).

Por outro lado, as necessidades de cautela e os perigos envolvidos no uso do humor logo começaram a ser ponderados (Saper, 1987), afinal "todos nós já vivenciamos a dor de ser escarnecido, provocado, zombado ou ridicularizado" (Kuhlman, 1984, p.77) e conhecemos os riscos e armadilhas eminentes ao uso do humor.

O psicanalista Lawrence Kubie ganhou lugar de destaque nessas ponderações ao advogar veementemente contra o uso do humor na clínica psicológica (Kuhlman, 1984; Saper, 1987). Os principais argumentos apresentados por Kubie envolviam o potencial do humor para mascarar a hostilidade do terapeuta com relação ao paciente, bem como a possibilidade de que o paciente se questione quanto à seriedade do trabalho do terapeuta ou se ressinta com a leveza do mesmo em face do seu sofrimento - interpretando-o como frio e cruel. Além disso, caso o paciente utilize o humor como defesa, o terapeuta pode estar reforçando este mecanismo; e caso o paciente tenha sido vítima de cruéis piadas na infância/adolescência, a expressão humorada do terapeuta pode ser entendida como uma agressão, independentemente de sua intenção.

Neste sentido, o psicoterapeuta Thomas Kuhlman (1984) reitera que o uso hostil do humor pode ser ainda mais ofensivo do que um insulto direto, uma vez que: 
- Viola as regras e o espírito da brincadeira: contravém a liberdade, prazer, vinculação e intimidade que são compartilhadas pelos participantes em momentos de risada verdadeira.

- Coloca maiores problemas de defesa à sua vítima do que aquelas de uma agressão verbal direta:

- Se a estrutura ou técnica deste humor é inteligente, a vítima surpresa terá dificuldade em responder à altura - não só pode haver confusão e dúvida sobre a intenção agressiva da expressão, como suas habilidades criativas podem ser dificultadas após tal golpe que, indireto, não é esperado. A natureza transitória/efêmera da interação humorada, por sua vez, faz com que qualquer resposta que não imediata e "ao nível" da anterior, seja socialmente inapta e "perca pontos" aos olhos reais ou fantasiados da plateia.

- Igualmente, o descomprometimento possibilitado pelo caráter indireto e lúdico do humor pode agravar o insulto: a vítima, ao ser desmentida, pode se sentir não só "feita de boba", como desprovida de argumentos para legitimar a ofensa.

Não obstante, esse autor afirma que embora muitos profissionais concordem com as ressalvas ao uso do humor, a maioria não compactua com a posição radical de Kubie contra o uso do humor na clínica psicológica (Kuhlman, 1984).

Nas palavras de Sultanoff (2013),

Kubie pode ser acurado em sua observação de que "humor é potencialmente destrutivo", mas ele falha em confiar na habilidade do terapeuta de selecionar o humor apropriado para o cliente ou ser capaz de responder efetivamente a uma negativa do cliente ao humor. Num sentido mais amplo, Kubie 
assumiu que os clínicos não são capazes de endereçar o impacto das intervenções que os clientes vivenciam como negativas. Muitas intervenções têm o potencial de serem destrutivas. Interpretações ou confrontações podem ser prejudiciais à aliança terapêutica, ainda assim, é improvável que Kubie sugerisse que os clínicos abandonassem esse tipo de resposta (pp. 393-394).

Nesta perspectiva, Saper (1987) ressalta que o mau uso de uma técnica terapêutica não deve ser considerado um argumento contra a mesma. Do mesmo modo, Kuhlman (1984) afirma que o uso hostil do humor por parte do terapeuta diz respeito mais à própria ética do profissional em questão do que às particularidades do humor. Esse autor salienta que existem questões muito mais complexas envolvidas nas especificidades da relação entre o fenômeno do humor e a psicoterapia, as quais merecem nossa atenção.

Contudo, ainda que exista uma extensa quantidade de livros e artigos discutindo o uso do humor na psicoterapia, eles têm demonstrado dificuldade em abranger tal complexidade. A maioria carece de sistematização teórica e/ou empírica na construção de seus argumentos (Saper, 1967; Sultanoff, 2013). Muitos acabam ainda por enfocar nos debates do "porquê" e "quando" usar o humor, mais do que compreender mais profundamente o seu papel neste contexto (Kuhlman, 1984). Por outro lado, grande parte dos trabalhos que discutem o papel do humor na psicoterapia e se utilizam sistematicamente da teoria clínica ou pesquisa para embasar seu uso, não só carecem de caracterizar melhor o fenômeno humorado (Kuhlman, 1984; Richman, 1996; Rutherford, 1994; Sultanoff, 2013;) como tendem a escolher uma abordagem teórica específica da psicologia para o diálogo (Freud, 1908; Jacobs, 2009; Kupermann, 2003; Rutherford, 1994).

Portanto, o objetivo deste capítulo é gerar uma visão compreensiva acerca do uso do humor na especificidade da práxis psicoterapêutica. Para este fim, teceremos um diálogo 
entre os processos e qualidades comuns a todas as psicoterapias e os processos e qualidades inerentes ao humor.

\subsection{O que é psicoterapia?}

A fim de discutirmos sobre o uso do humor no empreendimento específico da psicoterapia, faz-se necessária a compreensão dos processos e qualidades que a definem. Contudo, circunscrever o campo da psicoterapia não é uma tarefa fácil.

Parte do problema em se definir a atividade psicoterapêutica, segundo Wolberg (1988), advém tanto da histórica difusão da psicoterapia em diferentes abordagens, como da expansão da ajuda psicológica, ao longo dos anos, para um grupo cada vez maior de pessoas com queixas cada vez mais diversas. Neste sentido, para ajudar um só indivíduo e a fim de não negligenciar as considerações diagnósticas, de background, de cultura e de estilo de vida, o psicoterapeuta pode ter que aplicar informações pertinentes a fontes médicas, sociológicas, educacionais, reabilitativas, entre outras - tornando a pertinência da tarefa psicoterapêutica ainda mais difusa (Wolberg, 1988).

Entretanto, malgrado a dificuldade em construir uma definição única e abrangente ao campo da psicoterapia, a área de estudos e práticas psicoterapêuticas vem crescendo e se consolidando ao longo dos anos (Wolberg, 1988; Shultz \& Shultz, 2007). Além disso, seu movimento mais recente tem sido de integração e de diálogo entre as abordagens alcançando o ponto de um esforço para compreender os fatores e processos subjacentes que as unem (Isolan, Pheula, \& Cordioli, 2008). Desta forma, não resta dúvidas de que a psicoterapia possui suas fronteiras e se caracteriza como um empreendimento único, diferente das demais terapias.

Segundo Wolberg (1988), a psicoterapia diz respeito a uma forma de tratamento, por meios psicológicos, de problemas de natureza emocional. De acordo com esse autor, o 
centro do processo psicoterapêutico é o relacionamento que se estabelece entre paciente e terapeuta, o qual deve ser deliberadamente estabelecido, planejado e nutrido, visando: (1) remover, modificar ou retardar sintomas - focando, em último caso, na permanência do paciente em contato com a realidade; (2) correção de padrões interpessoais e relacionamentos perturbados; (3) promover maturação pessoal - focando na liberação de ricos recursos humanos para uma autorealização criativa, atitudes mais positivas perante a vida e relacionamentos mais gratificantes.

De modo semelhante, Cordioli e Giglio (2008) definem a psicoterapia como

métodos de tratamento realizados por profissionais treinados com o objetivo de reduzir ou remover um problema, uma queixa ou um transtorno de um paciente ou cliente, utilizando, para tal fim, meios psicológicos. São realizadas em um contexto primariamente interpessoal, a relação terapêutica, e utilizam a comunicação verbal como principal recurso. Caracterizam-se, ainda, por serem uma atividade eminentemente colaborativa entre paciente e terapeuta (p. 42).

Esses autores (Cordioli \& Giglio, 2008) ainda ressaltam que o objetivo da psicoterapia é que o paciente passe a dispor de um conjunto de recursos que o capacitem a: lidar melhor com suas emoções e relações interpessoais, ter um melhor controle sobre seus impulsos e sobre seus comportamentos desadaptativos, e ser mais efetivo no planejamento de sua vida e na tomada de importantes decisões.

Contudo, embora pertinentes e funcionais, estas definições carecem de maiores explicações e delineamentos: afinal, o que esses autores querem dizer por "meios psicológicos"? Partindo de que compreensões o psicoterapeuta interpreta uma forma de relacionamento como "perturbado"? O que significa "maturação pessoal" ou "lidar melhor" com emoções e relacionamentos? 
As seções seguintes deste trabalho se debruçam sobre estas questões visando a um aprofundamento dos meios, objetivos, processos e condições que delineiam o trabalho psicoterapêutico.

\subsection{Meios psicológicos: relação e experiência}

A relação humana é o meio psicológico fundamental pelo qual se dá a psicoterapia (Cordioli \& Giglio, 2008; Hycner, 1995; Sultanoff, 2013; Wolberg, 1988). A maior parte dos empreendimentos atuais envolve algum tipo de relação, mas a psicoterapia fundamenta-se na mesma: é o estabelecimento e os desenhos da relação terapeuta-paciente a matéria da construção de intervenções (Hycner, 1995; Wolberg, 1988).

Comumente, quando falamos de "psicológico", nos remetemos a fenômenos de natureza intrapsíquica (Hycner, 1995; Wolberg, 1988). Contudo, o psicológico é essencialmente relacional. Segundo Hycner (1995), a esfera do "entre" é parte central de nossa existência, uma vez que o sentido do nosso lugar no mundo também faz parte do nosso Ser. Desta forma, o individual é parte fundamental da natureza humana, mas não é único em sua constituição: esta engloba algo maior - a dimensão inter-humana - que envolve tanto o individual como o relacional, e é maior que a soma de ambos. É neste sentido que o autor afirma que uma ênfase excessiva no individual não só provoca uma separação "entre" pessoas, mas uma consequente separação também dentro da própria psique humana.

Quando os autores falam em "meios psicológicos", portanto, podemos subentender “relação". Entretanto, como Sultanoff (2013) apropriadamente observa,

Psicoterapia enquanto relacionamento é único, e os métodos pelos quais terapeutas constroem intimidade na aliança terapêutica são geralmente diferentes 
dos métodos pelos quais eles constroem intimidade em outros tipos de relacionamento (p. 393).

Segundo Hycner (1995), a fim de reconhecer e se ocupar da natureza inter-humana em seu trabalho, o psicoterapeuta precisa desenvolver um estado de awareness $^{19}$ com relação à mesma. Isto significa estar em contato vigilante - voltando seus sistemas sensório-motor, emocional, cognitivo e energético para a esfera do "entre”. Este estado, comumente chamado de "presença", possibilitaria ao terapeuta estar atento, simultaneamente, à sua própria existência, à experiência do outro, e ao desenvolvimento continuamente mutante da relação entre ambos.

Tal estado de presença, de acordo com autor (Hycner, 1995), implicaria uma atitude de "reverência pelo que é", uma espécie de aceitação tanto de si, como do universo incluindo as feridas e os aspectos que necessitam de mudança. Tal aceitação, entretanto, não deve ser confundida com complacência: o sujeito atua a partir do reconhecimento genuíno da realidade presente, ainda que esta realidade seja inaceitável. Para Hycner (1995), essa atitude por parte do terapeuta é fundamental, tanto com relação a si mesmo como no que diz respeito ao paciente:

- No terapeuta, a negação das feridas e das necessidades de mudança implicaria em mecanismos de defesa que bloqueiam e dificultam a disponibilidade e inteireza do Self no estado de presença. Tal dificuldade, por sua vez, não só pode indicar um ego fragilizado por parte do terapeuta - o que dificulta o direcionamento saudável da terapia (Cordioli \& Giglio, 2008) -, como entrava

\footnotetext{
19 A palavra awareness, nesta dissertação, é conservada no original por não haver correspondente exato da mesma no Português. A tradutora do livro de Hycner (1995) para o português cita na página 31, em uma nota de rodapé, a definição de awareness por Gary Yontef, segundo o qual awareness corresponde ao contato vigilante - movimento de voltar seus sistemas sensório-motor, emocional, cognitivo e energético para o momento de maior importância no campo indivíduo-meio.
} 
sua abertura e disponibilidade para o reconhecimento do paciente como ser essencialmente diferente.

- Com relação ao paciente, por sua vez, a negação de sua existência enquanto pessoa única e a consequente falta de reconhecimento de sua alteridade configurariam um entrave ao processo fundamental de individuação e à construção de intervenções que sejam "afinadas" com as necessidades que se apresentam.

Neste sentido, é no contexto maior voltado à presença que devem emergir as intervenções. As técnicas e conhecimentos devem servir como ferramentas que ajudem o psicoterapeuta tanto a encontrar este estado de awareness, como a criar e improvisar no momento presente da relação uma intervenção terapêutica específica para a situação (Hycner, 1995). Por outro lado, a ênfase excessiva na técnica e nos conhecimentos cognitivos não só aliena nossos sentidos, como produz uma atitude de previsibilidade que impede o desenvolvimento de uma abertura e disponibilidade ao momento presente. Ao ignorar nuances relacionais e pessoais, as intervenções de um terapeuta têm tantas chances de funcionar como um meio terapêutico de mudança quanto as ações de uma pessoa leiga com a intenção de ajudar (Sultanoff, 2013).

Outro aspecto referente aos meios psicológicos, ressaltado pela literatura, é a experiência: a psicoterapia ocorre pelo conjunto de experiências proporcionadas pela relação terapêutica (Cordioli \& Giglio, 2008; Isolan et al., 2008; Zeig, 2015; Wolberg, 1988).

Segundo Cordioli e Giglio (2008), grande parte do modo como as pessoas se comportam e consideram a si mesmas e aos outros é inconsciente - corresponde a redes implícitas de emoções, comportamentos, cognições e bioquímicas ativadas e desencadeadas fora da consciência. Este inconsciente, por sua vez, seria "procedural" - 
referente a processos que somente se evidenciam e se desenvolvem no desempenho das atividades, não sendo acessíveis diretamente à linguagem explícita ou à memória consciente.

É neste sentido que a criação de experiências se torna meio psicológico para a mudança: uma vez que grande parte das mudanças almejadas e dos processos envolvidos em psicoterapia são implícitos (Cordioli \& Giglio, 2008), as intervenções psicoterapêuticas não podem contar apenas com a dimensão explícita da linguagem e do raciocínio consciente, mas devem se embasar majoritariamente na criação de atividades e comunicações na relação cuja experiência para o paciente mobilize tais processos implícitos em direção à saúde (Zeig, 2015).

É sobre este direcionamento à saúde que falaremos a seguir.

\subsection{Objetivos gerais da psicoterapia: integração psíquica e empoderamento}

A definição específica dos objetivos de uma psicoterapia envolve a negociação e determinação entre terapeuta e paciente sobre o que se constitui o problema do paciente e o que é possível ser feito dentro das fronteiras psicoterapêuticas. Segundo Isolan et al. (2008), ainda que seja do terapeuta a determinação oficial de quais seriam os problemas que se apresentam para o trabalho terapêutico e os objetivos específicos a serem alcançados, esses objetivos e a forma de abordá-los devem ser aceitáveis pelo paciente.

Malgrado a diversidade de objetivos que possam se estabelecer dada a singularidade de cada paciente, estes precisam ser apropriados ética e profissionalmente ao trabalho do psicoterapeuta (Isolan et al., 2008). Nesta seção trataremos dos objetivos gerais de uma psicoterapia, a fim de delinear as finalidades específicas dessa práxis. 
A aquisição de um $\operatorname{Self}^{20}$ mais coeso e integrado aparece na literatura como finalidade última de um processo psicoterapêutico (Cordioli \& Giglio, 2008; Hycner, 1995; Wolberg, 1988). Segundo Cordioli e Giglio (2008), esta integração não só é uma condição para que ocorram as mudanças em psicoterapia, como, em casos extremos, se torna o objetivo máximo do trabalho. Neste sentido, Wolberg (1988) afirma que em casos de adoecimento emocional extremo, a função da psicoterapia se torna eminentemente a de preservação do contato do paciente com a realidade.

De acordo com Hycner (1995), o esforço da psicoterapia para alcançar a integração psíquica do Self perpassa a confirmação da alteridade do paciente na relação, pois é somente na relação que o ser humano pode construir um sentido de separação e individuação. Durante esse processo, conforme o terapeuta desenvolva uma relação de confiança com o paciente, o trabalho volta-se para a resolução e integração de processos intrapsíquicos que atuem como mecanismos de defesa e resistências impedindo o contato íntegro da pessoa consigo e com o mundo (Hycner, 1995; Jacobs, 2009; Kuhlman, 1984).

Neste sentido, intervenções que permitam uma awareness por parte do sujeito quanto a seus estímulos internos (sentimentos e impulsos) e às necessidades ou demandas do ambiente - por mais difíceis e contrárias ao seu Self ideal que sejam - são fundamentais para que o paciente não só organize e integre diferentes aspectos de sua vida, como consiga perceber e julgar de forma realista as questões vivenciadas (Cordioli \& Giglio, 2008; Jacobs, 2009). É somente através deste contato com a realidade que o paciente será capaz de: desenvolver responsabilidade por suas ações, escolhas e modo de ser; atualizar suas respostas com relação às condições atuais, corrigindo interpretações errôneas e construindo soluções mais efetivas; aumentar seu senso de si e sua capacidade

\footnotetext{
20 Self aqui é definido como a organização única de cada pessoa enquanto ser (Hycner, 1995; Richman,
} 2001). 
autorreflexiva (Jacobs, 2009). Estas intervenções, gradualmente, permitem a construção de um Self mais coeso e integrado, disponível ao diálogo com a realidade (Hycner, 1995).

Por outro lado, intervenções que incentivem movimentos de deflexão - que desviem ou difundam o contato possível do paciente com questões que precisem ser endereçadas dificultam o processo de awareness, de modo que as fronteiras entre o Self e o meio ficam vagas e pobremente definidas, e as respostas do sujeito não se atualizam ao momento presente, tornando-se inapropriadas e enrijecidas (Jacobs, 2009).

Destarte, ainda que em casos de transtornos mais graves, a pessoa não consiga construir um senso de Self forte e estável, a psicoterapia deve estar sempre direcionada ao contato com a realidade visando uma maior integração psíquica (Cordioli \& Giglio, 2008; Hycner, 1995).

Outro objetivo comum às diversas abordagens psicoterapêuticas, e profundamente relacionado ao anterior, consiste na participação mais ativa do sujeito no manejo de seus processos e situações de vida (Cordioli \& Giglio, 2008; Gonzalez Rey, 2011; Kuhlman, 1984; Richman, 2001; Rutherford, 1994) - a denominaremos neste trabalho como “empoderamento".

Segundo Zeig (2015), a criação de experiências na psicoterapia deve ter como orientação mais abrangente o empoderamento. Nesta direção, González Rey (2011) afirma:

vejo como um dos aspectos centrais da promoção de saúde o advento de sujeitos individuais e sociais ativos capazes de gerar e assumir novas alternativas de vida diante das condições objetivas pessoais que definem os limites objetivos das ações humanas. Esses limites sempre serão suscetíveis a produções subjetivas alternativas (p. 45). 
A possibilidade de tornar-se mais ativo no manejo de sua vida pessoal, de acordo com Kuhlman (1984), reflete a capacidade do ser humano para a auto-objetificação: a habilidade de construir-se ao mesmo tempo como sujeito e objeto. Tal capacidade permite à pessoa desenvolver o que Martin Buber chama de "presença-distanciada" (Hycner, 1995): a pessoa se encontra profundamente envolvida com o momento em questão e, ao mesmo tempo, é capaz de se distanciar deste momento e estar em contato com a totalidade maior de seus processos de vida. Este estado possibilita à pessoa estar em contato com o problema/dificuldade que se apresenta e, ao mesmo tempo, utilizar seus recursos para criar saídas alternativas ao mesmo (Jacobs, 2009; Kuhlman, 1984).

Ambos os objetivos - integração e empoderamento - são indissociáveis na forma como são aqui apresentados: o envolvimento ativo da pessoa em seus processos de vida auxilia no processo de integração dos mesmos em seu Self, enquanto o processo de integração permite um aumento progressivo na capacidade da pessoa de lidar com suas próprias questões de forma coerente consigo e com o meio.

Além desses dois grandes objetivos, é possível notar na literatura outros processos e estados que são considerados fundamentais para a saúde psíquica do sujeito (Cordioli \& Giglio, 2008; Isolan et al., 2008; Kuhlman, 1984; Richman, 2001; Rutherford, 1994). Esses são compreendidos, neste trabalho, como subjacentes aos dois objetivos gerais supracitados e podem ajudar a entender as orientações mais específicas implicadas no processo de integração e empoderamento desenvolvidos na relação terapêutica. Os principais processos/estados mencionados são:

- Aceitação: segundo Richman (2001), a essência de uma atitude positiva diante da vida - a qual faz parte de um estilo de vida saudável - seria a aceitação. Esta é tida pelo autor no sentido oposto ao de negação e corresponderia à admissão do inevitável e procura tirar o melhor dele. O autor afirma que é importante que a 
pessoa aceite a si, com todas as falhas e virtudes; aos outros, com seu próprio estilo de vida; e às adversidades como partes inevitáveis da vida. Tal postura se assemelha muito à atitude de "reverência pelo que é" discutido por Hycner (1995) e descrito acima.

Rutherford (1994) também descreve estado parecido ao apontar o conceito adleriano de "sanguíneo", que corresponderia a uma forma de ser do indivíduo saudável: estar triste quando a tristeza é apropriada, sem se desestruturar, e sentir prazer em coisas felizes, sem perder o seu senso de perspectiva. Em outras palavras, diz respeito à atitude de aceitar provas e eventos aborrecedores da vida e seguir voltando-se aos seus objetivos e tarefas. A autora aponta o desenvolvimento desta atitude por parte do paciente como um dos objetivos centrais da psicoterapia (Rutherford, 1994).

- Responsabilidade por si mesmo: diversas vertentes psicoterápicas consideram importante que o terapeuta crie condições para que o paciente assuma responsabilidade por suas ações, escolhas e modo de vida, mediante sua situação presente (Cordioli \& Giglio, 2008; Erickson \& Keeney, 2006; Flankl, 2014; Isolan et al., 2008; Jacobs, 2009; Kuhlman, 1984). A Gestalt Terapia, por exemplo, é uma das vertentes que foca no momento atual visando ajudar o cliente a aceitar a responsabilidade pelo que ele é e pelo que está fazendo, participando ativamente de suas escolhas (Jacobs, 2009). A Terapia Natural Elevada de O’Connell, por sua vez, ressalta a aceitação completa da responsabilidade pelos problemas emergentes, sem que esta responsabilidade se transforme em culpabilidade - de si, dos outros ou do mundo (Kuhlman, 1984). Também Cordioli e Giglio (2008), em sua revisão de literatura, apontam que uma das lições de vida aprendidas em psicoterapia deve ser a de assumir responsabilidade por suas próprias ações, tornando-se mais efetivo 
no manejo de sua vida pessoal. Tal aprendizado, segundo Richman (2001), faz parte de um estilo de vida saudável.

- Interesse social: trata-se de um conceito desenvolvido pelo psicólogo Alfred Adler, mas subsequentemente adotado por diversas vertentes (Kuhlman, 1984; Rutherford, 1994). Segundo Rutherford (1994), tal conceito se refere à consciência do sujeito de ser parte da comunidade humana e seu interesse em lutar por um futuro melhor para a humanidade. Desta forma, encontrar um lugar na sociedade e adquirir um sentido de pertencimento e contribuição seria um processo central para o desenvolvimento do sujeito e, portanto, parte fundamental da psicoterapia.

Neste sentido, também Richman (2001) discute que um dos componentes de um estilo de vida saudável seria "estar socialmente ativo" (p. 426). Esse autor ressalta a necessidade humana de vínculos que conduzam a um senso de coesão e partilha. Um estilo de vida saudável estaria, portanto, conectado com esta necessidade e envolveria a participação em atividades sociais e compartilhadas que impliquem relacionamentos coesos e a construção de um mundo melhor.

Outros autores, como Hycner (1995) e Kuhlman (1984), igualmente ressaltam a importância da experiência de um pertencimento universal, no qual a humanidade comum a todas as pessoas seja reconhecida no respeito às suas singularidades.

- Ser fisicamente ativo: segundo Richman (2001), ser fisicamente ativo é um dos componentes de um estilo de vida construtivo. Este inclui autocuidado, exercícios dos sentidos físicos e dos músculos, e hábitos físicos saudáveis em geral.

Uma vez que os sistemas simbólicos, emocionais, fisiológicos, corporais, sociais, etc. estão profundamente entremeados, não é possível e seria pouco saudável dissociar completamente as eventuais dificuldades em uma destas facetas 
das demais (González Rey, 2011; Wolberg, 1988). Desta forma, ainda que não seja da competência do psicoterapeuta intervenções diretamente físicas ou químicas (como já delineado na seção sobre os meios pelos quais as psicoterapias atuam), o mesmo precisa ficar atento a esta dimensão da saúde do paciente, tanto para fins diagnósticos, como para possibilidades de intervenções através de seus meios psicológicos.

- Coragem para ser imperfeito: segundo Chazenbalk (2005), a perturbação emocional que nos adoece psicologicamente advém da postura de levar muito a sério à vida e a nós mesmos. Neste sentido, Rutherford (1994) afirma que quando a pessoa se leva muito a sério - estando muito preocupada com sua conformidade/adequação -, ela perde a flexibilidade e espontaneidade em seus comportamentos, o que dificulta seu crescimento psicológico. Jacobs (2009) também afirma que uma das coisas mais difíceis para os pacientes é desenvolver e manter um senso positivo de autovalor enquanto descobrem algo sobre si que não cabe no seu Self ideal. Do mesmo modo, pacientes podem mostrar resistência à mudança por terem que admitir que sua forma de lidar com as coisas era faltosa de alguma forma (Kuhlman, 1984). Diante deste panorama, Rutherford (1994) ressalta a importância de que o terapeuta construa junto com o paciente um senso de coragem para ser imperfeito, o qual seria possível através da mudança de enfoque do produto e da perfeição para o processo e esforço.

- Capacidade de resolução de problemas: a psicoterapia deve proporcionar uma oportunidade não só para que o paciente resolva os problemas que tem enfrentado, mas para que desenvolva sua própria capacidade de resolução de problemas (Cordioli \& Giglio, 2008; Isolan et al., 2008). Desta forma, Rutherford (1994) afirma que a psicoterapia pode ajudar o cliente a sentir uma distância entre ele 
mesmo e seus problemas, possibilitando olhá-los com perspectiva. Kuhlman (1984) assume que tal distanciamento, promovendo um desapego emocional do problema, possibilita o empoderamento do sujeito quanto ao mesmo, permitindo focar na questão de uma forma que antes não era possível - viabilizando sua resolução. Esta é uma importante habilidade que pode ser aprendida na psicoterapia.

- Sentido e propósito: para Richman (2001), sentido e propósito são componentes centrais de qualquer estilo de vida construtivo. Viktor Frankl, criador da $\operatorname{logoterapia}(\log o s=$ sentido$)$, compreendia a pulsão por sentido, e não por prazer ou poder, como o aspecto inerente à condição humana (Frankl, 2014). Segundo esse autor, o sentido de vida não é algo abstrato ou geral, porém profundamente concreto e específico, variando de pessoa para pessoa e de momento para momento: ele está relacionado a assumir responsabilidade por sua própria existência, reconhecendo profundamente as demandas concretas que a vida apresenta como tarefas ou desafios para realização. Neste sentido, Frankl (2014) compara a questão do sentido de vida com um jogo de xadrez:

O que importa, por conseguinte, não é o sentido da vida de um modo geral, mas antes o sentido da vida específico de uma pessoa em um determinado momento. Formular esta questão em termos gerais seria comparável a perguntar a um campeão de xadrez: 'diga, mestre, qual é a melhor jogada do mundo?'. Simplesmente não existe algo como o melhor lance ou um bom lance à parte de uma situação específica num jogo e da personalidade peculiar de um adversário (p. 63).

O sentido da vida, desta forma, também não está na felicidade em si ou na liberdade de agir concretamente: encontrar um sentido de responsabilidade em sua 
existência não coloca como condição só vida e alegrias, pois há também um sentido de responsabilidade e uma demanda única da vida a ser cumprida no sofrimento e na morte - trata-se de uma atitude que se assume diante da vida (Frankl, 2014).

Como podemos notar acima, os aspectos humanos saudáveis que precisam ser observados pelo terapeuta ao formular os objetivos da psicoterapia não são completamente alheios uns aos outros, de modo que o desenvolvimento de um deles influencia ou implica nos demais. Contudo, distinguir entre esses objetivos nos ajuda no delineamento das fronteiras que constituem o trabalho psicoterapêutico.

Uma vez mais claras essas fronteiras, podemos passar à discussão sobre os processos psicoterapêuticos específicos que podem ser desenvolvidos na relação terapêutica para que esses objetivos sejam alcançados.

\subsection{Processos psicoterapêuticos: agentes específicos de mudança}

Nesta seção endereçaremos as discussões levantas por Cordioli e Giglio (2008) e Isolan et al. (2008) no que concerne aos agentes de mudança subjacentes às mais diversas abordagens psicoterapêuticas.

Cordioli e Giglio (2008) destacam o delineamento de Karasu (1986) quanto a esses agentes, agrupando-os em: a) experiências afetivas, b) aumento das habilidades cognitivas

e c) regulação do comportamento. A esses grupos, os autores acrescentam os agentes sociais (interpessoais, grupais ou sistêmicos). Eles ainda ressaltam que mesmo que algumas abordagens psicológicas possam enfocar mais explicitamente em um grupo de agentes em detrimento dos demais, a maioria utiliza-se dos diferentes grupos de agentes de mudança, em alguma medida. A seguir apresentaremos uma síntese dos principais processos que se constituem como agentes de mudança em psicoterapia. 
a) Agentes de natureza afetiva: dizem respeito a processos que impliquem a expressão e o compartilhamento de emoções, interrompendo os mecanismos de defesa e resistências, e tornando o paciente mais acessível e predisposto a ser influenciado. Alguns destes processos de mudança são:

a. Mobilização afetiva e catarse: refere-se à mobilização afetiva em maior ou menor grau que precisa acontecer nas diferentes psicoterapias (Cordioli \& Giglio, 2008; Isolan et al., 2008). Este desbloqueio no contato e expressão de afetos pode tornar possível, ainda, a expressão catártica: alívio da ansiedade e da tensão por ocasião da expressão e revivência de afetos originalmente ligados a experiências traumatizantes e que haviam sido reprimidos. A expressão de afetos em um contexto terapêutico mostra ao paciente que ele é capaz de vivenciá-los e manejá-los, reduzindo a necessidade da manutenção de defesas contra os mesmos - o que, por sua vez, possibilita uma experiência de maior autenticidade e de aceitação de tais aspectos como parte de sua pessoa. Desta forma, a expressão de afetos é um fator de cura fundamental e pode ser usado por todas as psicoterapias.

b. Apoio terapêutico: trata-se do suporte oferecido ao paciente pelo terapeuta. Este apoio tem aspectos que se assemelham a uma boa relação mãe-filho: implica sentir-se aceito por parte de um terapeuta em quem deposita confiança e com relação ao qual tem expectativas de que possa auxiliá-lo. O terapeuta, por sua vez, atua de maneira a viabilizar ao paciente o fortalecimento e a estruturação do ego, a internalização de aspectos positivos da postura do terapeuta e o desenvolvimento de uma autoimagem mais saudável. Este apoio pode tomar, inclusive, contornos bastante diretivos - envolvendo, por exemplo, sugestão, aconselhamento, 
estabelecimento de limites, revisão de tarefas, auxilio na solução de problemas, etc. $\mathrm{O}$ apoio terapêutico é a base dos processos psicoterapêuticos e é fundamental para endereçar os sentimentos de desmoralização e autoimagem ruim, que anulam ou dificultam as capacidades de colaboração e enfrentamento do paciente. Segundo Cordioli e Giglio (2008), este agente pode se tornar, ainda, o único processo passível de ser realizado em caso de pacientes com transtornos psiquiátricos graves, lacunas importantes no desenvolvimento, ou déficits de ego acentuados.

c. Processos de identificação com a pessoa do terapeuta: segundo Cordioli e Giglio (2008), identificação é um processo psicológico pelo qual um indivíduo assimila um aspecto, uma propriedade, um atributo do outro e se transforma, total ou parcialmente, segundo o modelo dessa pessoa. $\mathrm{Na}$ terapia, o paciente internaliza aspectos reais da pessoa do terapeuta (regras de conduta e autocontrole, valores morais, formas de pensar e agir, etc.), especialmente, os aspectos idealizados e com os quais se identifica. Neste sentido, o terapeuta deve servir de modelo ao paciente: ao mesmo tempo em que compartilha de experiências com o último, age de forma mais saudável e integrada diante das mesmas.

b) Agentes de natureza cognitiva: relativo a processos que forjam a aquisição de novos padrões de pensamento e de percepção, assim como a promoção de um maior conhecimento e compreensão de si mesmo e da realidade a sua volta ampliando as habilidades cognitivas do paciente e possibilitando, dentre outras coisas: a) melhor julgamento (teste) de realidade; b) aquisição de recursos que o capacitem a lidar melhor com suas emoções, impulsos, comportamentos e relações 
interpessoais; c) maior capacidade de empatia com os outros (Cordioli \& Giglio, 2008). Alguns dos agentes que favorecem esta ampliação seriam:

a. Psicoeducação: realizada mediante explanações do próprio terapeuta, leituras, ou consultas a internet, folhetos, etc. A psicoeducação tem como objetivo aumentar o conhecimento do paciente, familiarizá-lo sobre: o transtorno ou problema que está vivenciando; os sintomas e mecanismos envolvidos em sua origem e perpetuação; a prevenção de recaídas; os recursos dos quais pode dispor para lidar com os déficits resultantes da doença, próprios ou existentes na comunidade, ou com os efeitos colaterais dos medicamentos; o modelo de terapia; os mecanismos e estratégias utilizadas para remover sintomas; a forma pela qual pode se dar essa remoção.

b. Reestruturação cognitiva: referente a intervenções visando à correção de distorções cognitivas. Envolve processos de mudança seja nos pensamentos automáticos - ideias prontamente disponíveis sobre um acontecimento ou situação, cujo conteúdo pode ser realístico ou distorcido - seja nas crenças subjacentes disfuncionais - estruturas cognitivas organizadas ao longo da vida que formam um corpo coeso de afirmativas a respeito de si próprio, da realidade a sua volta, ou sobre seu futuro, as quais guiam as percepções da realidade, a tomada de decisões, e as atitudes e comportamentos de uma pessoa.

c. Insight: diz respeito à aquisição de consciência por parte do sujeito de suas motivações e sentimentos mais profundos, de aspectos de sua vida aos quais antes não tinha acesso. Segundo Cordioli e Giglio (2008), esta consciência se dá através de um processo "intuitivo" - que não se reduz a uma tomada 
de consciência em nível intelectual, mas envolve mobilização emocional e outros níveis de sentido - consistindo em uma nova forma de perceber a natureza mais profunda das coisas. Este insight possibilita mudanças de atitude e de comportamentos, e novas soluções para problemas. Seu objetivo último é a reorganização da personalidade. Processos de insight forjam reestruturações cognitivas, e o inverso também pode acontecer.

c) Agentes comportamentais: referente a processos que propiciam a aprendizagem do manejo de ações e hábitos por parte dos pacientes, possibilitando maior autonomia na regulação dos mesmos (Cordioli \& Giglio, 2008). Alguns dos agentes de mudança comportamentais na psicoterapia são:

a. Aprendizagens em sentido geral: diz respeito às lições de vida que o paciente aprende em psicoterapia. Afinal, diante dos objetivos psicoterapêuticos, o trabalho do terapeuta torna-se justamente a construção de condições implícitas ou explicitas para que o paciente aprenda a viver construtivamente.

b. Condicionamento clássico, operante e aprendizagem social: o condicionamento clássico diz respeito ao pareamento entre um estímulo incondicionado (um estímulo que naturalmente envolve respostas orgânicas) e um estímulo a ser condicionado (um estímulo "neutro" podendo ser comportamentos, situações, pessoas, lugares, etc. - que passam a obter respostas orgânicas depois de terem sido associados com o estímulo incondicionado). Por outro lado, o condicionamento operante diz respeito ao reforço ou punição de algum tipo de comportamento, diminuindo ou aumentando a frequência do mesmo; enquanto a aprendizagem social diz respeito ao aprendizado pela observação de outros indivíduos. Desta forma, 
na terapia o paciente pode aprender por meio da observação aos demais; dos reforços do terapeuta a seus comportamentos saudáveis; bem como através da construção de novas associações entre estímulos. Esta última forma de aprendizado comporta a extinção e habituação que serão tratadas a seguir.

c. Extinção e habituação: na extinção, uma resposta condicionada diminui e se extingue, caso a pessoa, de forma repetida, tenha contato com o estímulo condicionado sem a presença do estímulo incondicionado. Em outras palavras, a apresentação repetida de uma dica na ausência de estímulo ao qual está associada reduz a probabilidade de expressão da memória condicionada, forjando um novo aprendizado (Cordioli \& Giglio, 2008). A extinção é o principal mecanismo responsável pelo enfraquecimento e desaparecimento de respostas aprendidas por pareamento, e dá forma à técnica psicoterapêutica de "dessensibilização sistemática", muito utilizada como forma de intervenção em casos de fobias ou respostas reativas. Já na habituação, ocorre uma diminuição espontânea e progressiva das respostas do organismo a um estímulo não nocivo, quando permanece em contato por tempo necessário com o referido estímulo ou quando este contato é repetido. Reações autonômicas desaparecem rapidamente. A diferenciação entre ambas é confusa para muitos autores, segundo Cordioli e Giglio (2008), caso tenha ocorrido um condicionamento na origem dos sintomas o termo mais apropriado é extinção.

d) Agentes sociais (interpessoais, grupais ou sistêmicos): refere-se a intervenções de caráter social, familiar e interpessoal, partindo da compreensão de que os 
problemas individuais emergem em um meio social mais amplo (Cordioli \& Giglio, 2008). Alguns dos agentes de mudança específicos a este contexto são:

a. Grupais: referente aos mecanismos psicológicos que ocorrem no contexto de grupo e que podem influenciar seus membros - podendo ser utilizados terapeuticamente. São alguns destes mecanismos:

i. Identificação - tanto projetiva quanto introjetiva - com os demais membros e com o líder;

ii. Comportamento imitativo e aprendizagem interpessoal, pela observação dos outros participantes (aprendizagem social);

iii. Correção de percepções distorcidas por meio de uma visão mais realista, pela percepção da universalidade dos seus problemas e pelo compartilhamento de informações;

iv. Catarse, pela possibilidade de obter alívio com a ventilação de emoções e com a instilação da esperança;

v. Desenvolvimento do altruísmo (vontade de ajudar os outros);

vi. Apoio decorrente do fato de se sentir parte de um grupo (coesão grupal) e ter afinidade com seus membros e com as tarefas;

vii. Socialização desenvolvida pelo convívio em grupo (contato visual, aperto de mão, etc.);

viii. Recapitulação nas vivências de grupo de situações vividas em família e em outros grupos, trazendo à tona questões envolvendo inveja, ciúmes, rivalidades, disputas com figuras de autoridade ou mesmo problemas caracterológicos - as quais podem ser usadas pelo terapeuta. 
b. Familiares: diz respeito ao lugar que ocupa o sujeito no sistema familiar e o modo como as relações deste sistema participam na configuração da subjetividade de cada um de seus membros e vice-versa - gerando influências tanto em direção ao adoecimento e à regressão como à saúde. As terapias familiares se atentam e utilizam primariamente dos processos desenvolvidos neste sistema, na criação de intervenções.

c. Interpessoais: referente às relações interpessoais e a forma como influenciam e são influenciadas pelos pacientes. Os agentes de mudança interpessoais utilizam as formas de o paciente se relacionar no contexto social enquanto modo de intervir na dificuldade que trouxe o paciente à terapia.

Os processos delineados acima enquanto agentes de mudança na psicoterapia são colocados em ação por intermédio de um grande número de intervenções terapêuticas, as quais comumente envolvem, de forma explícita ou não, mais de um desses agentes. Como Cordioli e Giglio (2008) ressaltam, os processos cognitivos, as experiências afetivas, os comportamentos individuais e o ambiente social se permeiam, de modo que não é possível uma completa dissociação entre os mesmos. Portanto, ainda que o agrupamento proposto acima tenha fins didáticos à compreensão dos diferentes processos que podem estar envolvidos nas mudanças psicoterapêuticas e que caracterizam sua prática, faz-se mister destacar que tais categorias são fluidas e que a mudança em psicoterapia envolve diversos destes agentes, seja de forma explícita ou implícita.

Podemos observar também que os processos supracitados não são psicoterapêuticos em si - eles precisam de um direcionamento segundo objetivos terapêuticos. Além disso, eles dependem de certas condições básicas para que possam acontecer na relação terapêutica. A próxima seção deste capítulo versa sobre tais condições fundamentais que 
viabilizam os mais diversos empreendimentos psicoterapêuticos. Trata-se dos fatores terapêuticos comuns às diferentes psicoterapias.

\subsection{Condições fundamentais: fatores comuns a todas as psicoterapias}

Segundo Isolan et al. (2008), embora muitos psicoterapeutas considerem como principais fatores de mudança em psicoterapia suas formas de intervenção particulares e as técnicas específicas para sua execução, estudos e revisões de literatura iniciados na década de 1970 vêm mostrando que diferentes abordagens psicoterapêuticas apresentam resultados e índices de eficácia semelhantes. Uma das explicações mais comuns atribuídas a estes achados, de acordo com Isolan et al. (2008), remete à existência de fatores terapêuticos comuns, ou não específicos: elementos comuns subjacentes a todas as formas de psicoterapia, os quais seriam considerados os grandes responsáveis pelas melhoras obtidas pelas diferentes abordagens.

Ainda que estes fatores comuns não impliquem desconsiderar o uso de técnicas específicas para viabilizar determinados processos de mudança, eles envolvem a compreensão de que essas técnicas se tornam possíveis ou, no mínimo, possuem um maior impacto quando determinadas características do paciente e da relação terapêutica estiverem presentes (Isolan et al., 2008).

A seguir apresentaremos estes fatores terapêuticos comuns na forma como são endereçados por Isolan et al. (2008). Esses autores os distinguem em: a) fatores do paciente; b) fatores do terapeuta; e c) fatores do par terapeuta-paciente.

a) Fatores do paciente

a. Motivação: é caracterizada pelo desejo e pela disposição do paciente em fazer mudanças de vida mediante a solução efetiva de problemas - envolve seu interesse em falar com outra pessoa e ser ouvido, valorizado e 
compreendido (Isolan et al., 2008). Há certo consenso na literatura sobre a importância da motivação na realização de mudanças psicoterapêuticas (Isolan et al., 2008; Zeig, 2015). Há também outros fatores comuns que estão implicados na configuração desta motivação, como: o grau de sofrimento/incômodo com a situação; a procura espontânea por tratamento; a esperança e expectativa de cura ou de receber ajuda; e até qualidades do próprio vínculo - se o paciente gosta do terapeuta e consegue confiar nele e admirá-lo.

b. Crenças e expectativas do paciente sobre a psicoterapia: a esperança e a confiança por parte do paciente de que ele receberá ajuda e de que a terapia será efetiva são fundamentais para o processo psicoterapêutico. Por outro lado, a presença de crenças que envolvem ver os problemas como externos ou distantes de si mesmo pode dificultar este processo (Isolan et al., 2008).

c. Facilidade de estabelecer uma relação terapêutica: a capacidade de estabelecer um vínculo e uma aliança de trabalho com o terapeuta é um outro fator relacionado ao paciente que é fundamental para o bom andamento de uma psicoterapia - havendo certo consenso também neste aspecto (Isolan et al., 2008). Algumas das características do paciente que podem prever a sua capacidade de estabelecer um bom vínculo e aliança com o terapeuta são: as qualidades de suas relações de objeto e as qualidades das relações interpessoais. Além disso, Zetzel (citado por Isolan et al., 2008) afirma que para o estabelecimento de uma profunda aliança terapêutica é necessário que o paciente tenha, previamente, um certo grau de maturidade do ego. Igualmente, Hycner (1995) ressalta que precisamos de certo senso de segurança para arriscarmos nosso Self ao contato íntimo 
com outro, e que pessoas com ego fragilizado e pouco senso de Self podem não conseguir estabelecer relações genuínas por questões de autopreservação. Desta forma, ainda que a fragilidade do ego possa ser uma das dificuldades a serem endereçadas na psicoterapia, ela é também preditora de dificuldades no estabelecimento de uma relação terapêutica.

d. Grau de sofrimento psíquico: para que o paciente apresente alguma motivação para mudança, algum grau de sofrimento psíquico e/ou desconforto é necessário. No entanto, um elevado grau de sofrimento pode dificultar o processo terapêutico, seja por encontrar-se diretamente associado a dinâmicas psicopatológicas, as quais podem comprometer a aliança terapêutica; seja por implicar um sentido de desmoralização e de autoimagem ruim no paciente, prejudicando ou até mesmo anulando por completo sua capacidade de colaboração e de enfrentamento. Desta forma, a intensidade do sofrimento psíquico é um dos principais fatores do paciente que está relacionado com os resultados em psicoterapia (Isolan et al., 2008).

e. Grau de tolerância à ansiedade: toda terapia envolve certo nível de ansiedade por trabalhar com mobilização emocional e promoção de mudanças. Desta forma, se o paciente apresenta um baixo grau de tolerância à ansiedade, este é um fator que dificulta os processos terapêuticos, se configurando como um mal prognóstico (Isolan et al., 2008).

f. Habilidade de resolução de problemas: pacientes com dificuldades ou baixo nível de desenvolvimento intelectual, cognitivo ou emocional; bem como aqueles que apresentam muita rigidez nestes processos, podem apresentar maior dificuldade no desenvolvimento de habilidades para resolução de 
problemas - o que, por sua vez, pode colocar determinadas condições especiais ao desenvolvimento do processo terapêutico (Isolan et al, 2008).

g. Grau de reatividade emocional: de acordo com os autores, um maior grau de reatividade emocional torna o paciente mais acessível e pré-disposto a ser influenciado (Cordioli \& Giglio, 2008; Isolan et al., 2008).

b) Fatores do terapeuta

a. Autenticidade: de acordo com Sultanoff (2013), diz respeito a um "senso de consistência interna que irá naturalmente resultar em se apresentar como 'real'. Não há fachada ou falsidade em seu ser e, portanto, nenhuma fachada em sua presença” (p. 396). Isolan et al. (2008) também afirmam que esta atitude básica envolve tanto uma coerência e autoconsciência por parte do terapeuta, como uma disposição para compartilhar esta consciência. A autenticidade do terapeuta é uma das condições necessárias para a mudança terapêutica, pois este estado de disponibilidade e inteireza de Self permite que o paciente se sinta à vontade para expor suas ideias e sentimentos (Hycner, 1995; Isolan et al., 2008).

b. Calor humano: envolve a atitude de aceitação, respeito, afirmação, apoio, compaixão, carinho e elogios por parte do terapeuta (Isolan et al., 2008).

c. Empatia: Isolan et al. (2008) definem empatia como o entendimento do ponto de vista do paciente e de sua visão de mundo. Já Kupermann (2003) ressalta que a empatia não se trata apenas de um entendimento, mas, sobretudo, de "uma modalidade de conhecimento e experimentação das sensações e afetos vivenciados pelo outro" (p. 238). Esta experimentação não se dá por analogia, projeção, ou identificação, mas pelo fato de que os impulsos internos e as expressões do sujeito formam unidades psíquicas, de 
modo que vivenciar as expressões do outro induz em nós os impulsos internos destas expressões, permitindo sentirmos "dentro" do outro - caso nos coloquemos disponíveis, em sintonia na relação.

De outra maneira, Hycner (1995) fala da inclusão - movimento essencial do terapeuta referente à mobilização intensa do próprio Ser em direção à existência do outro, ao mesmo tempo em que se mantém centrado em si, em uma tentativa de vivenciar a experiência da outra pessoa tanto quanto a sua própria.

Todas estas visões possuem em comum a vivência profunda da experiência do outro, sem perder seu próprio senso de Self, conseguindo compreender na própria experiência a forma como outra pessoa vivencia e percebe o mundo. A empatia é, portanto, uma condição fundamental ao empreendimento psicoterapêutico, pois é a partir dela que podemos construir intervenções coerentes com a pessoa do paciente. Segundo Isolan et al. (2008), os estudos sobre fatores comuns na psicoterapia mostram um tamanho de efeito para a empatia que chega a ser maior que aquele dos estudos relacionados à aliança terapêutica.

d. Outros aspectos importantes do psicoterapeuta ressaltados por diferentes autores (Cordioli \& Giglio, 2008; Isolan et al., 2008) são:

i. Interesse genuíno e competência profissional;

ii. Que seja pessoalmente bem integrado;

iii. Que tenha capacidade de continência a respostas reativas: capacidade de diferenciação e de reavaliar seus próprios padrões de exigência e necessidade de reconhecimento;

iv. Que tenha curiosidade; 
v. Que tenha capacidade de cuidar dos outros;

vi. Que seja criativo: perceba novas formas de lidar com o problema do paciente;

c) Fatores do par terapeuta-paciente

a. Desenvolvimento de uma aliança terapêutica: diz respeito à colaboração ativa entre paciente e terapeuta, visando o bom andamento da terapia. Envolve: acordo sobre os objetivos terapêuticos; acordo sobre as tarefas e assuntos a serem analisados; e um vínculo emocional entre terapeuta e paciente (Isolan et al., 2008).

b. Desenvolvimento de um vínculo: refere-se ao vínculo afetivo entre a pessoa do paciente e a pessoa do terapeuta. Ele é mais do que uma aliança terapêutica: vai além dos papéis psicoterapêuticos e configura algumas das qualidades da relação entre os participantes (Isolan et al., 2008). É neste sentido que Greenwald (1975) ressalta a importância de que o terapeuta goste de seu paciente e o estime.

c. Transferência: trata da repetição, na relação com o terapeuta, de padrões primitivos de relação de objeto. Os aspectos transferenciais da relação terapêutica são uma importante fonte de informação sobre os padrões de relacionamento do paciente e da forma como conduzir a terapia.

Os fatores do paciente, do terapeuta e do par terapeuta-paciente também interagem inevitavelmente entre si, e juntos constituem as condições básicas que viabilizam os empreendimentos específicos de cada psicoterapia.

Este tópico, intitulado “O que é psicoterapia?”, visou compreender a práxis psicoterapêutica por meio do delineamento de suas particularidades. Para este fim, discutimos os meios, os objetivos, os processos e as condições básicas que caracterizam o 
empreendimento psicoterapêutico de forma geral. O próximo tópico deste trabalho objetiva compreender o uso do humor neste empreendimento. Para tal, teceremos um diálogo entre o presente capítulo e o capítulo 1 desta dissertação, utilizando também a literatura já existente no campo da relação entre humor e psicoterapia, a fim de dar base e legitimidade à discussão.

\section{$2.6 O$ uso do humor na psicoterapia}

Existe entre os psicoterapeutas de diversas abordagens um crescente consenso sobre o grande potencial do uso do humor na psicoterapia, assim como sobre a necessidade de conhecimento e sensibilidade por parte do terapeuta na compreensão do lugar deste fenômeno no processo psicoterapêutico (Greenwald, 1975; Kuhlman, 1984; Saper, 1987; Sultanoff, 2013).

Alguns desses autores falam de uma afinidade natural entre o humor e a psicoterapia - esteja ela no fato de o humor consistir em um processo de insight (Kuhlman, 1984), nas diversas camadas de sentido com que trabalha (Richman, 1996), na lida com os paradoxos (Panichelli, 2013), ou na sua própria forma de celebrar a vida. Contudo, mesmo esses autores ressaltam a importância de que o uso do humor esteja integrado ao cenário terapêutico.

Podemos discutir esta integração do humor na práxis psicoterapêutica, por sua vez, a partir de duas perspectivas diferentes, porém complementares, que aparecem na literatura: o humor enquanto técnica e o humor enquanto estado.

Segundo Kuhlman (1984), o humor pode assumir o papel tanto de uma tática psicoterapêutica - uma ferramenta que promove o alcance de algum objetivo - como de uma estratégia - objetivo ou meta psicoterapêutica a ser alcançada. Neste sentido, diversos outros autores também consideram não apenas o potencial terapêutico do uso pontual da 
expressão humorada, como também a importância do senso de humor de forma geral: seja enquanto atitude assumida pelo terapeuta (Chazenbalk, 2005; Erickson \& Keeney, 2006; Greenwald, 1975; Kuhlman, 1984), seja enquanto um objetivo geral da psicoterapia (Cai et al., 2014; Chazenbalk, 2005; Erickson \& Keeney, 2006; Kuhlman, 1984; Panichelli, 2013).

Assim, enquanto a expressão humorada pode ser direcionada de forma terapêutica ou não, grande parte dos autores que se referem ao senso de humor o entendem como essencialmente terapêutico. Os autores Craik, Lampert e Nelson (citado por Richman, 2001), ao pesquisarem sobre o conceito de "senso de humor" construído pelo senso comum, chegaram às seguintes especificidades: uma pessoa com senso de humor seria uma pessoa socialmente apropriada e calorosa; aberta e responsiva; que aprecia o humor, mesmo que não seja engraçada e quando usa o humor é competente em seu uso; possui flexibilidade cognitiva e habilidade para usar e compreender múltiplos níveis de pensamento simultaneamente; possui uma abordagem doce e madura ao mundo e aos problemas; e, por fim, seu humor toca sobre experiências e verdades universais, tornando a realidade mais suportável.

Já Kuhlman (1984) e Rutherford (1994) traduzem este senso de humor na figura do "verdadeiro humorista". Para Rutherford (1994), o verdadeiro humorista possui qualidades sociais inerentes à sua postura, estando em contato com o vínculo inato que conecta todos os seres humanos. Essa autora afirma que o humor excessivo ou inapropriado não é sinal de um senso de humor, mas de um "distúrbio de humor" (p. 217). Neste sentido, Kuhlman (1984) afirma que o humorista

respeita o fato de que há tantas visões diferentes da realidade como há pessoas. Ele está disposto a compartilhar e celebrar erros de constrição e lutas neuróticas como direitos universais da condição humana. Ele procura e promove tais experiências de pertencimento universal (p. 55). 
Além disso, esse autor afirma que o verdadeiro humorista não é aquele que promove a experiência cômica a todo momento, mas alguém que tenha a habilidade generalizada de reconhecer os paradoxos da vida e aceitar ambas as perspectivas cômicas e trágicas como partes do processo de viver e, portanto, instâncias que precisam ser vividas.

Como podemos observar nas definições acima, o senso de humor de fato parece englobar várias posturas terapêuticas previamente discutidas como: a capacidade de resolução de problemas, a aceitação, o interesse social, e a capacidade inerentemente humana de desenvolver contato genuíno com o mundo. Richman (2001) acrescenta, ainda, que o senso de humor só se torna a base de uma personalidade madura quando acompanhada de um sentido de vida.

Fica claro, portanto, que o senso de humor não seria apenas a capacidade de perceber as coisas como engraçadas ou criar algo engraçado, como define Saper (1987); mas, mais fundamentalmente que isso, consistiria em uma atitude diante da vida, uma forma de viver que se aproxima da estética humorada discutida no capítulo 1. Envolve a senciência, a celebração do constante ritmo da vida e da capacidade humana de reerguer-se, uma perspectiva étnica, contingente e episódica sobre as situações e um oportunismo inteligente que permita lidar com o momento de forma única e criativa (Langer, 1953; Corrigan, 1981).

O presente tópico visa abordar a relação entre a psicoterapia e a totalidade do fenômeno humorado, englobando ambas as facetas - estado e expressão. Para tal, as seções seguintes se debruçam sobre a forma como os processos e qualidades característicos do fenômeno do humor podem se relacionar com os meios, objetivos, processos e condições que caracterizam a psicoterapia. 


\subsection{Meios psicológicos e humor: relação e experiência}

Assim como a psicoterapia, o humor também se fundamenta na relação. Como já ressaltado no capítulo 1, o humor é um fenômeno humano de caráter eminentemente relacional. Assim sendo, a vivência humorada não existe de forma reificada - ela emerge de um contexto constituído na complexa interação entre as dimensões cultural, social, relacional e individual.

Na literatura voltada ao uso do humor na psicoterapia, este caráter do fenômeno humorado também é ressaltado. Richman (1996), por exemplo, chama atenção para o fato de o humor ser "acima de tudo interativo" (p. 565). Kuhlman (1984), por sua vez, caracteriza o humor como um processo transacional, envolvendo a pessoa do paciente, do terapeuta e a relação. Neste sentido, podemos considerar o humor como um fenômeno propriamente inter-humano, característico da esfera do "entre".

Considerar o humor como um fenômeno do "entre" tem implicações fundamentais na sua relação com a psicoterapia. A primeira delas diz respeito à importância de não assumirmos a postura radical de banir o humor dos empreendimentos terapêuticos, como fez o psicanalista Laurence Kubie. Isto porque, assim como discutimos anteriormente, excluir uma das dimensões interativas de nosso Ser não só provoca uma separação "entre" pessoas, mas também na própria psique do indivíduo. Em outras palavras, essa exclusão compromete não só a autenticidade da relação, como o processo terapêutico de integração. Desta forma, é importante que o terapeuta se coloque aberto para a emergência da expressão humorada como parte do contexto relacional humano.

A questão, portanto, não é se o humor deve ou não acontecer na psicoterapia, mas o lugar que ele ocupa neste contexto.

Como discutimos na seção sobre "meios psicológicos", é importante que o psicoterapeuta desenvolva uma awareness direcionada para a esfera do "entre" - de modo 
que ele consiga estar atento, simultaneamente, a si próprio, ao outro, e à relação. Este estado de presença também é essencial para que o profissional possua um senso de timing terapêutico com relação à expressão humorada (Rutherford, 1994).

O humor, por sua vez, pode ter um importante papel no desenvolvimento de uma atitude de "reverência pelo que é", essencial para que o terapeuta se encontre presente na relação: muitos estudiosos apontam que a atitude de "rir de si mesmo" implica um profundo reconhecimento e aceitação de nossa humanidade (Chazenbalk, 2005; Kuhlman, 1984; Rutherford, 1994). Rutherford (1994), por exemplo, afirma que rir de nós mesmos "significa que nós nos aceitamos tão erráticos, bobos e confusos quanto todas as outras criaturas são" (p. 217). Do mesmo modo, Richman (1996, 2001) atribui esta atitude à compreensão "afetuosa" das nossas manias e loucuras - percebendo-as como parte da condição humana. Neste sentido, é possível afirmar que o terapeuta com senso de humor pode ter maior facilidade em reconhecer e aceitar genuinamente a si mesmo, aos outros e às situações - inclusive nos aspectos que precisam de transformação - fazendo-se verdadeiramente presente na relação.

Entretanto, a negação por parte do terapeuta de suas feridas e necessidades de mudança pode conduzi-lo ao uso do humor como mecanismo de defesa. Segundo Kuhlman (1984), o psicoterapeuta pode usar o humor indevidamente para aliviar sua ansiedade acerca do papel de terapeuta, ou se descomprometer diante de conteúdos ou formas de relacionamento com os quais tenha dificuldade de lidar. Em contrapartida, a negação da alteridade do paciente ou a rejeição de sua dificuldade podem levar o terapeuta a usar o humor como forma de "sermão", muito mais do que uma manifestação que respeite o paciente e os objetivos terapêuticos (Kuhlman, 1984).

Neste sentido, o lugar que o humor ocupa na psicoterapia está primariamente relacionado ao estado de presença que o terapeuta desenvolve na relação com o paciente: é 
no contexto maior, voltado ao reconhecimento e manejo dos processos inter-humanos, que o humor deve emergir.

A criação de experiências nesse contexto, por sua vez, também se relaciona com o fenômeno humorado. Como discutimos anteriormente, grande parte das mudanças e dos processos envolvidos em psicoterapia corresponde a redes implícitas de emoções, cognições e comportamentos - as quais não são acessíveis diretamente à linguagem explícita e à memória consciente, mas apenas mobilizadas pela experiência. Da mesma forma, como vimos no capítulo 1 , o humor envolve processos não apenas cognitivos, mas também cinestésicos, afetivos e simbólicos (Suls, 1983), de modo que o sentido do humor não se dá na linguagem explicita (Hempelmann, 2012), mas nos processos implícitos que constituem o jogo humorado.

Nesta direção, diversos estudiosos da relação entre humor e psicoterapia ressaltam o grande valor do humor neste contexto enquanto forma de comunicação cuja experiência engloba múltiplos processos e níveis de sentido. Sultanoff (2013), por exemplo, destaca que a intervenção humorada tem o potencial de mobilizar um processo dinâmico e interativo entre as quatro áreas que constituem o empreendimento psicoterapêutico: emocional, comportamental, cognitiva e bioquímica.

De outro modo, Richman (1996) afirma que as duas linhas de pensamento que constituem a experiência humorada dizem respeito a diferentes níveis de consciência: uma das linhas empregaria a lógica discursiva tradicional e, portanto, estaria associada à comunicação aberta e consciente; enquanto a outra, inesperada, corresponderia a uma lógica de processos primários, ou poéticos - mais relacionados à autenticidade inconsciente. Desta forma, de acordo com o autor, o humor permite endereçar diferentes níveis de sentido ao mesmo tempo, podendo tratar de temas difíceis na terapia de uma maneira mais aceitável. Do mesmo modo, Greenwald (1975) afirma que o humor, como a 
poesia, teria a habilidade de chegar a um nível mais profundo da psique humana de maneira comparativamente não invasiva e, ainda assim, penetrante - tornando a experiência humorada uma das mais potentes ferramentas no arsenal do psicoterapeuta.

Além disso, como vimos anteriormente, o humor se constitui na ambiguidade - a incongruência entre as duas linhas de pensamento emergentes não é resolvida, mas ganha um sentido lógico surpreendente. Desta forma, autores como Kuhlman (1984) e Panichelli (2013) ressaltam o potencial do humor na lida com paradoxos e duplo-vínculos na clínica - podendo contemplar ambas as camadas de sentido simultaneamente.

Assim sendo, podemos afirmar que o humor influencia e é influenciado profundamente pelos processos implícitos que constituem a psicoterapia. Na próxima seção exploraremos o relacionamento entre o humor e o direcionamento terapêutico destas influências.

\subsection{Objetivos psicoterapêuticos e humor}

O estado de presença do psicoterapeuta permite que ele reconheça e desenvolva formas de manejar os processos que ocorrem no "entre", criando experiências terapêuticas. Mas é importante que este terapeuta esteja atento aos objetivos que determinam o caráter terapêutico de sua empreitada. Da mesma forma, entre os autores que estudam a relação humor-psicoterapia existe uma unanimidade sobre a importância de compreender o lugar que o humor ocupa em relação aos propósitos terapêuticos estabelecidos (Kuhlman, 1984; Rutherford, 1994; Saper, 1987; Sultanoff, 2013).

No que concerne ao uso do humor por parte do terapeuta, esses autores são categóricos em afirmar que o fato da vivência humorada ser prazerosa não necessariamente implica que ela esteja mobilizando o paciente a processos mais saudáveis

(Kuhlman, 1984; Rutherford, 1994; Saper, 1987; Sultanoff, 2013). A intenção ou propósito 
do uso do humor pelo psicoterapeuta deve ser claramente terapêutico, assim como é importante que ele reconheça seu uso inapropriado - caso aconteça - e busque lidar com o mesmo de uma forma que seja terapêutica para o paciente (Kuhlman, 1984; Sultanoff, 2013).

Nesta seção discutiremos a relação entre o fenômeno humorado e os objetivos gerais da psicoterapia.

Como discutido anteriormente, a finalidade última de um processo psicoterapêutico é a construção de um Self mais coeso e integrado. Neste sentido, o trabalho terapêutico é voltado para resolução e integração de processos psíquicos que atuem como resistência ou mecanismo de defesa impedindo o contato íntegro da pessoa consigo e com o mundo. Estes processos atuam promovendo desvios ou difusões no contato com recursos e questões que precisam ser endereçadas. Não obstante, um dos objetivos da terapia é construir condições para uma awareness mais completa por parte do sujeito tanto com relação a seus estímulos internos quanto às necessidades e demandas do ambiente.

O humor pode ter um importante papel na lida com processos que atuem como resistência ou mecanismo de defesa. Ele tem o potencial de "distrair" estes processos (Chazenbalk, 2005; Kuhlman, 1984), ou contemplá-los em algum nível (Panichelli, 2013), ao mesmo tempo em que conduz a awareness do sujeito para questões terapêuticas importantes. Kuhlman (1984) apresenta algumas das características do humor que viabilizam essa lida:

- Seu caráter lúdico: se a pessoa aceita o convite à brincadeira e entra em um set lúdico, ela não consegue manter simultaneamente sua atenção no set usual cujos processos mantêm a resistência e os mecanismos de defesa. Como discutimos no capítulo 1, o mundo lúdico difere claramente de nossa experiência ordinária (ainda que dialogue profundamente com ela): o jogo é uma atividade 
voluntária, com referências de tempo e espaço distintas, regras próprias e uma qualidade única de "diversão". Contudo, é preciso estar atento: assim como uma pessoa pode entrar nesse mundo lúdico, ela também pode sair dele caso a mensagem do outro seja demasiadamente ameaçadora ou contrária a seus processos subjetivos - fazendo com que a pessoa deixe de compartilhar das transgressões, ideias e experiências que constituem esse set lúdico.

- Seu caráter implícito: a mensagem do humor é um convite ao qual é mais difícil de se resistir, porque é um convite implícito (envolve processos indiretos e, ainda, encontra-se "disfarçado" de brincadeira).

- Sua demanda por participação ativa: o humor é um processo constituído na relação, logo exige a participação ativa da pessoa em sua construção - isto dificulta a resistência da pessoa em se engajar.

- Além disso, o uso do humor, inclusive de formas não verbais (cartuns, gestos, etc.), pode circunscrever a resistência que se dá por meio da verborragia do paciente - o convite ao lúdico e o caráter inesperado da expressão humorada podem interromper, mesmo que temporariamente, o exercício usual de expressão e pensamento desse paciente.

Contudo, como ressaltamos na seção anterior, o humor também pode ser utilizado como mecanismo de defesa e resistência. Segundo discutimos no primeiro capítulo (Quadro 3), a forma humorada de se situar no mundo enfoca na senciência, em detrimento da presciência: o humor implica um contato mais presente e honesto com a realidade (Corringan, 1983). Contudo, o humor não emerge de forma independente dos participantes, e isto significa que, embora o fenômeno humorado sugira um contato mais presente e honesto com a realidade, essa honestidade pode ser seletiva: existem muitas manifestações humoradas que não estão em contato com a totalidade dos processos de 
vida, mas que advém de uma awareness voltada apenas para determinados processos hegemônicos. Deste contato restrito resultam as expressões humoradas inapropriadas ou descomprometidas socialmente - inclusive as preconceituosas.

O psicoterapeuta, portanto, deve estar atento para perceber se uma manifestação humorada é algo que permite o contato com processos importantes previamente fora da awareness, ou se reforça a desconexão com os mesmos - tanto de sua parte como da parte do paciente. Segundo Chazenbalk (2005), o humor é terapêutico quando aumenta a capacidade dos envolvidos de perceber a si mesmos e às suas relações com os demais, de forma precisa.

Partindo da literatura (Chazenbalk, 2005; Jacobs, 2009; Kuhlman, 1984; Panichelli, 2013; Rutherford, 1994) e com o intuito de forjar uma melhor compreensão sobre o lugar que o humor pode ocupar nesta empreitada em direção a um Self mais coeso e integrado, desenvolvemos o Quadro 5. Este quadro, propõe-se a esclarecer algumas formas através das quais o humor pode permitir uma maior ou menor awareness da totalidade dos processos que constituem a realidade presente. 


\section{Quadro 5}

Relações entre o fenômeno do humor e sua potencialização ou deflexão do contato na psicoterapia.

\begin{tabular}{|l|l|}
\hline Humor e a potencialização do contato & Humor e a fuga do contato \\
\hline $\begin{array}{l}\text { Quando o humor permite uma conexão mais } \\
\text { profunda com a realidade, ou quando implica } \\
\text { considerar questões que sejam importantes para a } \\
\text { saúde da pessoa: valores, sentimentos, problemas, } \\
\text { etc. }\end{array}$ & $\begin{array}{l}\text { Quando o humor é usado como negação defensiva } \\
\text { de uma realidade, ou quando implica não levar a } \\
\text { sério questões que sejam importantes para a saúde } \\
\text { da pessoa: valores, sentimentos, problemas, etc. }\end{array}$ \\
\hline $\begin{array}{l}\text { Quando o humor conduz o paciente a uma direção } \\
\text { levemente diferente, permitindo: uma maior } \\
\text { conexão com o tema de importância ou trabalho } \\
\text { psicoterapêutico em andamento; ou uma mudança } \\
\text { de perspectiva que possa ser integrada ao que } \\
\text { estava sendo tratado no processo terapêutico. } \\
\text { direção completamente diferente, causando: uma } \\
\text { desconexão do tema de importância ou do } \\
\text { trabalho terapêutico em andamento; ou uma } \\
\text { mudança de cenário tão brusca que o paciente não } \\
\text { consiga integrar a intervenção ao que estava } \\
\text { acontecendo na terapia ou ao trabalho terapêutico } \\
\text { mesmo que para o terapeuta esta conexão } \\
\text { exista. }\end{array}$ \\
$\begin{array}{l}\text { Quando o paciente está: reproduzindo seus } \\
\text { processos de resistência e mecanismos de defesa } \\
\text { na terapia, abordando temas irrelevantes, ou } \\
\text { "definhando" em um exercício intelectual } \\
\text { desconectado dos reais processos implícitos que o o } \\
\text { mobilizam - e o humor proposto pelo terapeuta } \\
\text { interrompe ou oferece um ângulo distanciado e } \\
\text { incongruente sobre estes processos hegemônicos, } \\
\text { permitindo ao paciente se dissociar dos mesmos e } \\
\text { entrar em contato com a totalidade maior de seus } \\
\text { processos e vivências. }\end{array}$ & $\begin{array}{l}\text { Quando o paciente está engajo em importantes } \\
\text { processos e valores e o terapeuta propõe através } \\
\text { do humor um ângulo distanciado ou incongruente } \\
\text { sobre os mesmos - reforçando a dissociação de } \\
\text { queston, recursos e vivências fundamentais ao } \\
\text { trabalho terapêutico, mais do que facilitando o } \\
\text { contato com os mesmos. }\end{array}$ \\
\end{tabular}

Fonte: Elaboração da autora. 2016.

Nas palavras de Panichelli (2013), "o objetivo é claro: trazer o cliente a uma posição onde sorrir ou rir para o problema se torna possível não a fim de evita-lo, mas para aumentar sua capacidade de encará-lo (...)” (p. 448). Neste sentido, o uso do humor pode ter também importantes implicações ao processo de empoderamento a ser construído na psicoterapia.

Autores como Greenwald (1975) e Rutherford (1994) afirmam que o humor permite aos sujeitos ganhar perspectiva sobre suas dificuldades, mostrando aos mesmos que eles possuem opções, capacidade de escolha e muitas forças. Segundo Kuhlman (1984), tal perspectiva seria graças à capacidade do humor de promover o desapego emocional de um sintoma ou problema, permitindo a emergência de um novo foco, antes difícil demais de ser abordado. 
De acordo com o que foi discutido no capítulo 1, o humor reconhece valores instituídos como sérios, para depois subvertê-los através do que Corrigan (1981) chama de "sorte lógica" ou "oportunismo inteligente". Ao estabelecer uma relação mais honesta com a realidade, o cômico reconhece os valores e crenças que instituímos como "verdades" enquanto o que eles verdadeiramente são: valores e crenças. Este reconhecimento permite ao sujeito uma perspectiva distanciada quanto às deduções comuns que se seguem a uma determinada convicção e, por conseguinte, uma abertura a outras implicações e possibilidades diante da mesma. O resultado é o surgimento de uma saída lógica inesperada que utiliza, de forma não convencional, as convicções que o sujeito possui sobre o que as coisas devem fazer e significar.

Desta forma, o humor pode funcionar como ferramenta para construir experiências de empoderamento junto ao paciente. Por permitir o reconhecimento e a subversão de valores e crenças hegemônicas, o humor possibilita ao paciente aceitar suas dificuldades e, ao mesmo tempo, acessar recursos anteriormente inacessíveis para lidar com as mesmas, tornando-se mais ativo no manejo de suas próprias questões de vida.

Contudo, o fenômeno do humor, em si, não diz nada sobre os valores e crenças específicas a serem subvertidos. Deste modo, o humor pode atuar mais como reificador destes processos hegemônicos e sintomáticos do que como ferramenta de empoderamento sobre os mesmos. Este é o caso quando a manifestação humorada:

- Subverte e invalida valores e lógicas importantes na contestação desses processos hegemônicos - reforçando os últimos;

- Desvia o foco em favor destes processos sintomáticos, tratando de assuntos e valores que em nada estão relacionados com as questões de importância;

- Ou emerge de um desapego e desconexão extrema dos valores e crenças compartilhadas em um meio social, resultando em manifestações que 
consideramos "sem noção" ou até mesmo em risadas patológicas (onde não há o senso de timing que emerge de uma relação mais integrada com o mundo).

Destarte, é de fundamental importância que o psicoterapeuta não assuma o humor como naturalmente subversivo e empoderador na clínica, mas esteja atento aos processos que subjazem a ele e aos sentidos que ele possui no contexto psicoterapêutico da relação.

O fenômeno humorado também deve ser pensado com relação aos demais processos e estados fundamentais para a saúde psíquica do sujeito, como veremos a seguir:

- Aceitação e humor: Já exploramos neste capítulo sobre a relação que o humor possui com a atitude de aceitação. Como vimos, o humor envolve uma relação mais honesta e presente com a realidade, o que implica, de certa forma, uma aceitação desta realidade pelo que verdadeiramente é.

Por outro lado, "aceitação" não diz respeito a admitir algo passivamente ou advogar em seu favor, mas à atitude de admitir o inevitável e procurar tirar o melhor dele (Richman, 2001). Do mesmo modo, o fenômeno do humor não emerge de uma postura passiva e fatalista diante da realidade, mas do enfoque no oportunismo inteligente face às condições presentes.

Neste sentido, a forma humorada de se situar no mundo não significa necessariamente a exclusão de sentimentos de infelicidade ou de momentos de sofrimento, mas implica a aceitação de ambas as perspectivas cômicas e trágicas como partes do processo de viver. Esta atitude se relaciona profundamente com a descrição adleriana do indivíduo saudável: estar triste quando a tristeza é apropriada, sem se desestruturar, e sentir prazer em coisas felizes, sem perder o senso de perspectiva (Rutherford, 1994). 
Portanto, a presença de uma atitude humorada pode ser importante para o processo de aceitação na terapia. Contudo, como já discutimos, se a pessoa usa essa atitude humorística somente para determinados aspectos condizentes com seus processos subjetivos rígidos, pode ser que suas expressões de humor possuam uma profunda atitude de negação apenas "disfarçada" de uma atitude de aceitação.

Um bom senso de humor somente se desenvolve quando o sujeito passa a vivenciar esta estética humorada enquanto uma forma geral de vida. A psicoterapia, neste sentido, deve almejar este senso.

- Responsabilidade por si mesmo e humor: como discutimos no capítulo 1, a relação entre humor e responsabilidade é um assunto controverso. Attardo (1993) afirma que uma das funções sociais específicas do humor é o descomprometimento - o qual se torna possível graças à estrutura de brincadeira sob a qual o humor transmite as mensagens, permitindo o uso da retratação: “eu só estava brincando". Contudo, como vimos no capítulo 1, esta possibilidade de evasão não é absoluta, pois não conduz necessariamente à reformulação das inferências provocadas pela mensagem humorada e ainda podem levar ao questionamento: "Que tipo de pessoa brinca com um assunto desses ou desta forma?". Portanto, o fato de o humor ser um tipo de brincadeira não o exime da responsabilidade sobre suas expressões.

Por outro lado, o fato de o humor permear várias camadas de sentido - de modo a se constituir majoritariamente de processos implícitos sob um discurso explícito - pode facilitar outra forma de descomprometimento: "não foi isso que eu quis dizer”. Entretanto, não há nada na literatura humorada que discuta sobre 
esta possibilidade e não podemos inferir que no humor este potencial de evasão seja de qualquer forma maior do que em outras formas de comunicação que envolvam fundamentalmente uma mensagem implícita sob a linguagem explícita.

Além disso, como discutimos anteriormente, alguns autores apontam que o humor pode ser utilizado tanto para apoiar processos de negação que fazem parte dos mecanismos de defesa e resistência do sujeito; quanto para conduzir o paciente a se comprometer com temas que tem evitado ou atitudes que tem tido (Kuhlman, 1984; Richman, 1996).

Deste modo, é importante que o psicoterapeuta esteja especialmente atento aos mecanismos de descomprometimento do humor e aos momentos em que ele pode ser utilizado como uma forma mais leve e amorosa de assumir responsabilidade (Richman, 2001).

- Interesse social e humor: o humor tem importantes relações com o interesse social, uma vez que ele é um meio universal de construção de relacionamentos (Jacobs, 2009).

Como vimos no capítulo 1, o caráter lúdico do humor permite que duas pessoas que brinquem humoradamente uma com a outra experienciem o aumento de um senso de coesão e partilha entre si. Contudo, esta experiência de partilha não necessariamente implica um contato mais autêntico: duas pessoas podem unir-se em um jogo humorado justamente para distanciar-se de um contato mais honesto com o mundo ou até mesmo entre si. Neste sentido, um humor que integre o sujeito na comunidade e potencialize seu sentido de pertencimento e contribuição precisa envolver o contato com as necessidades 
dos demais envolvidos (Rutherford, 1994), e uma visão afetuosa e tolerante das manias e loucuras da condição humana (Richman, 2001).

Por outro lado, Jacobs (2009) ressalta que o humor que permita à pessoa a experiência social de se divertir e de ser uma companhia divertida pode não só acrescentar ao seu senso de autovalor, como contribuir para que se torne mais socialmente ativa. Desta forma, o uso do humor na psicoterapia, bem como o incentivo de seu uso em outros contextos, pode ter grande potencial no desenvolvimento do interesse social por parte do paciente.

- Ser fisicamente ativo: falando mais diretamente dos benefícios físicos e químicos do humor, podemos mencionar: diminuição dos hormônios de estresse, aumento no nível de anticorpos, relaxamento muscular, bem como ativação e exercício de sistemas corporais como: cardiovascular, digestivo e ósseo (Chazenbalk, 2005; Sultanoff, 2013).

Contudo, como discutimos anteriormente, os sistemas fisiológicos, simbólicos, emocionais, corporais, sociais, etc. encontram-se profundamente entremeados. Desta forma, um humor que prejudique de alguma forma a saúde psicológica do paciente também pode ter efeitos físicos negativos tanto em curto prazo (por exemplo, o estresse gerado por uma ofensa em forma de humor), como em longo prazo (por exemplo, o humor que impeça o sujeito de endereçar questões que estejam the prejudicando, causando maior estresse com situações cotidianas ou até resultando em manifestações psicossomáticas).

- Coragem para ser imperfeito: se o humor, por um lado, pode ser potencialmente perigoso, por outro, uma abordagem severa em terapia também pode ter seus perigos. Como ressalta Rutherford (1994), muitos clientes já tiveram o suficiente de severidade em suas vidas. 
O humor possui um importante papel na construção de uma atitude mais leve e acolhedora do sujeito com relação a suas imperfeições - o que, por sua vez, leva a uma maior flexibilidade e autenticidade em seus comportamentos. Algumas das qualidades e processos do humor que contribuem para esta atitude são:

- Não levar a vida numa perspectiva tão trágica e condenadora. Como vimos no capítulo 1 , enquanto a estética trágica possui a fatalidade como forma básica de se situar no mundo (as ações definem o caráter essencial de uma pessoa e seu futuro); a estética humorada possui como forma básica a fortuna (as ações são apenas oportunidades do momento para lidar com o meio, e não condenações de caráter). O senso de humor, portanto, pode permitir ao paciente reconhecer e lidar com ações das quais não se orgulhe, sem que estas signifiquem a condenação de si ou do outro.

- Maior flexibilidade com relação aos valores. Como já apresentamos acima, o humor reconhece nossas crenças e valores instituídos como "sérios", mas o faz como parte de um processo maior de subvertê-los. Deste modo, o humor pode possibilitar uma atitude alternativa e lúdica com relação às características ou ações valoradas como imperfeições do sujeito.

- Mudança de enfoque: do produto e da perfeição, para o processo e esforço. Como discutimos no capítulo 1, o humor emerge de uma apreciação da forma como as ações humanas constituem-se a cada momento enquanto saídas criativas às dificuldades impostas pelo meio. Neste sentido, o uso do humor pode conduzir o sujeito a tirar o foco do 
produto final e da perfeição, e direcioná-lo à maior valorização do processo e do esforço a cada instante. Esta mudança de foco, como vimos anteriormente, é fundamental para o desenvolvimento de outra atitude com relação a nossas imperfeições (Rutherford, 1994).

Entretanto, faz-se mister destacar que o humor também pode ser usado com finalidade crítica condenadora, de modo que ainda que possua processos cômicos, sua atitude subjacente seja trágica, pautada em valores rígidos que ditam a forma como a expressão humorada irá "moralizar" o outro. O terapeuta precisa tomar cuidado com esta atitude.

Neste sentido, Kuhlman (1984) ressalta a importância de que o psicoterapeuta desenvolva, ele mesmo, uma flexibilidade e uma disponibilidade para rir de si. O autor defende que o psicoterapeuta deve estar disposto a passar vergonha, perder seu status e até reverter a hostilidade sobre si mesmo, caso isso seja terapêutico ao paciente. Do mesmo modo, outros autores, como Chazenbalk (2005), Greenwald (1975), Jacobs (2009) e Rutherford (1994) também mencionam a importância de que o terapeuta não leve tão a sério seu papel, enrijecendo suas perspectivas.

A fim de que o terapeuta ajude o paciente a desenvolver uma atitude saudável com relação às imperfeições, ele mesmo precisa desenvolvê-la em si. Diversos autores apontam que o desenvolvimento de um senso de humor por parte do terapeuta pode ter um importante papel neste empreendimento.

- Capacidade de resolução de problemas e humor: de acordo com o que discutimos no capítulo 1, o humor envolve mecanismos lógicos (LM) incomuns e extremamente complexos na resolução de sua incongruência. Nesta direção, 
autores como Cai et al. (2014) e Manfredi et al. (2014) afirmam que o humor pressupõe o domínio de várias habilidades neurocognitivas básicas: tanto para ser percebido, como para ser vivenciado. Desta forma, podemos compreender que o fenômeno humorado em si já implica diversas habilidades básicas que são importantes para que um sujeito tenha a flexibilidade e autonomia lógica necessárias para solucionar problemas. Mais ainda, podemos supor que o uso do humor pode treinar estas habilidades no sujeito.

Contudo, como temos explorado neste capítulo, a resolução de problemas subjetivos não é tão simples, e envolve não só os mecanismos lógicos do humor, mas a forma como utilizamos estes mecanismos: o humor pode contribuir para a capacidade de resolução de problemas na medida em que favorece os processos de integração e de empoderamento do sujeito. Por este ângulo, são muitos os autores que defendem o potencial do humor para forjar uma mudança de perspectiva no paciente quanto ao problema que enfrenta, contribuindo para uma lida mais saudável com o mesmo (Chazenbalk, 2005; Jacobs, 2009; Kuhlman, 1984; Rutherford, 1994; Sultanoff, 2013).

- Sentido, propósito e humor: Frankl (2014) ressaltava o humor enquanto uma importante ferramenta para possibilitar à pessoa cumprir criativamente e com certo prazer as demandas da vida que fossem de grande sofrimento. Em outras palavras, esse autor compreendia o humor como um truque útil para que o sujeito não perdesse o sentido de vida, mesmo nos momentos difíceis.

Do mesmo modo, Richman (2001) afirma que um dos caminhos para uma vida de propósitos e sentidos seria o humor, pois um "coração alegre" (p. 427) não só permite seguir com as responsabilidades e demandas da vida, como pode ele mesmo ser uma tarefa ou desafio demandado por essa vida. Em 
contrapartida, a recíproca é verdadeira: somente aquele que reconhece os sentidos e propósitos de sua própria existência poderia desenvolver um senso de humor maduro e saudável.

Assim sendo, também é importante que o terapeuta esteja atento à relação das manifestações humoradas com um possível sentido de vida ou com a ausência do mesmo.

Além disso, alguns autores acreditam que o desenvolvimento de um senso de humor perante a vida seja o propósito maior de toda psicoterapia (Cai et al., 2014; Chazenbalk, 2005; Erickson \& Keeney, 2006; Kuhlman, 1984; Panichelli, 2013; Rutherford, 1994). Como vimos anteriormente, a definição de senso de humor feita por esses autores de fato engloba vários dos estados e atitudes terapêuticas discutidas acima. Assim sendo, faz sentido assumirmos o senso de humor como uma das finalidades da psicoterapia, bem como um dos indicadores de seu progresso.

Nesta seção discutimos algumas das implicações do uso do humor com relação aos objetivos psicoterapêuticos. Na seção seguinte trataremos da relação entre o fenômeno do humor e alguns dos processos psicoterapêuticos específicos que podem ser desenvolvidos visando aos objetivos acima.

\subsection{Processos psicoterapêuticos e humor}

A seguir discutiremos as relações entre o fenômeno do humor e os principais processos que se constituem como agentes de mudança em psicoterapia.

a) Humor e agentes de natureza afetiva

a. Humor, mobilização afetiva e catarse: por envolver processos emocionais implícitos na construção de seus sentidos, o humor implica 
necessariamente em uma profunda mobilização afetiva. Nesta perspectiva, Chazenbalk (2005) considera o humor um meio facilitador da catarse, assim como Sultanoff (2013) compreende a expressão humorada enquanto um potencial veículo para descarregar e aliviar conflitos mal resolvidos.

Por outro lado, para além dos processos emocionais de uma vivência humorística particular, o humor também produz afetos específicos enquanto fenômeno: prazer, alegria, "graça". Neste sentido, autores como Saper (1987) e Sultanoff (2013) compreendem que a vivência humorada não pode ocupar o mesmo espaço psicológico que emoções angustiantes (tais como raiva, tristeza e ansiedade), uma vez que provoca gozo e alegria. Desta forma, esses autores acreditam que, ainda que o sentimento de angústia retorne, a experiência pontual do humor pode interromper momentaneamente $\mathrm{o}$ sentimento de inércia e melancolia em uma pessoa, o que, por sua vez, pode produzir não só um alívio, como também a perspectiva de que sua depressão, ansiedade ou raiva podem diminuir. Assim sendo, Kuhlman (1984) compreende que o humor pode servir a curto prazo para "desescalar" o imediatismo e a severidade de uma crise emocional.

Ademais, estes e outros autores também consideram o potencial diagnóstico do humor com relação aos afetos (Chazenbalk, 2005; Kuhlman, 1984; Rutherford, 1994; Sultanoff, 2013). Chazenbalk (2005) acredita que o humor pode ser utilizado para driblar as resistências do sujeito e investigar os sentimentos do mesmo com relação a alguma questão ou situação. De outra forma, Sultanoff (2013) aponta que a 
recusa do paciente em se engajar em trocas humoradas, ou sua insatisfação com o fato de que o terapeuta o faça rir, podem indicar que o paciente está em um movimento deliberado de alimentar sua angústia ou depressão. Além disso, o uso inapropriado do humor, ou sua ausência podem indicar distúrbios em outras áreas emocionais, segundo afirma Rutherford (1994).

b. Humor e apoio terapêutico: não há muito na literatura aqui abordada que trate diretamente sobre a relação entre o uso do humor e o apoio na psicoterapia. Contudo, Kuhlman (1984) reforça o potencial paradoxal do humor, que permite manter o apoio ao paciente, ao mesmo tempo em que o provoca à mudança. Segundo esse autor, o uso provocativo do humor em uma relação de apoio, carinho, responsabilidade e preocupação envia a seguinte mensagem: "nós podemos brigar sem ter que matar ou abandonar um ao outro (...) eu sou forte o suficiente para ser seu pai" (Nelson citado por Kuhlman, 1984, p. 67). Do mesmo modo, Greenwald (1974) afirma que muito na terapia depende da intenção do terapeuta, de modo que o humor deve expressar algo como esta mensagem:

Eu sei que você está sofrendo agora, mas eu também sei que você tem as forças e habilidade para se afastar do seu sofrimento, olhar para ele, ver o que você pode fazer com ele, e como você pode decidir mudar, como você pode dominar esta situação (Greenwald, 1974, p. 116).

Tais mensagens em muitas formas se aproximam da atitude de apoio descrita no tópico sobre psicoterapia, a qual envolve o sentimento do 
paciente de ser aceito por um terapeuta em quem confia, e a atitude diretiva do terapeuta, ajudando-o a efetuar mudanças.

c. Humor e processos de identificação com a pessoa do terapeuta: o terapeuta serve como modelo ao paciente também com relação ao uso do humor. Autores como Chazenbalk (2005) e Rutherford (1994) afirmam que o senso de humor por parte do terapeuta é fundamental não só por contribuir ao direcionamento terapêutico da sessão, como também por servir como exemplo de uma forma saudável de se colocar no mundo e de endereçar as questões da vida.

b) Humor e agentes de natureza cognitiva

a. Humor e psicoeducação: encontramos na literatura algumas relações entre o humor e processos de psicoeducação que possam atuar como agente de mudança positiva. Por um lado, o humor pode ser utilizado pelo terapeuta para melhorar a absorção pelo paciente dos conhecimentos que o terapeuta julga necessário: sobre seu sintoma, prognóstico, prevenção de recaídas, etc. Segundo Attardo (2008), existe um grande corpo de publicações em como e por que utilizar o humor no contexto de aprendizagem. Por outro lado, o próprio senso de humor pode ser ensinado de forma psicoeducativa. Cai et al. (2014), por exemplo, realizaram um grupo de treinamento em habilidades humoradas com pacientes esquizofrênicos, baseado no treinamento criado pelo estudioso do humor Paul Mcghee, o qual seguia os seguintes passos: determinar a natureza do senso de humor e se cercar de humor; se tornar mais brincalhão e aprender a não se levar tão à sério; rir mais frequentemente e aprender a contar piadas ou histórias engraçadas; 
brincar com a linguagem, pegadinhas, palavras sem sentido e exageros; encontrar ironias e coincidências humoradas no cotidiano; tomar-se levemente e rir de seus próprios erros; encontrar humor em situações estressantes; e usar o humor para sobreviver e como mecanismo de coping. Esses autores constataram que o treinamento exerceu influências positivas no grupo, como a diminuição dos níveis de depressão e ansiedade e o aumento do senso de humor (Cai et al., 2014).

b. Humor e reestruturação cognitiva: autores como Chazenbalk (2005), Kuhlman (1984) e Sultanoff (2013) ressaltam o humor como forma de intervir nas distorções cognitivas do paciente. Neste sentido, Kuhlman (1984) dá lugar de destaque ao humor crítico.

Segundo esse autor, o humor crítico diz respeito a expressões humoradas que critiquem o paciente como tática para promoção de mudanças. Contudo, esta crítica não diz respeito a uma imposição agressiva ao paciente - como é o caso de uma interpretação diretiva ou um humor "moralista". Ela envolve convencer o paciente da própria absurdidade de seu comportamento, crença ou pensamento, desafiandoo a subvertê-los.

Como vimos anteriormente, a subversão no humor consiste em uma lógica inesperada que se utiliza de forma incomum do senso comum que já temos do que as coisas deveriam fazer e significar - permitindo um caminho de sentido pouco usual que une ambas as linhas de pensamento (comum e incomum).

Contudo, no humor crítico, ao invés de criar uma saída lógica incomum aos desdobramentos comuns de uma crença ou valor do paciente - 
oferecendo uma perspectiva alternativa sobre os mesmos - , o terapeuta reproduz e acompanha a saída lógica distorcida que o próprio indivíduo apresenta com relação a uma convicção- espelhando para o paciente a absurdidade dos desdobramentos que ele considera comuns.

Desta forma, segundo Kuhlman (1984), no humor crítico o paciente se depara com, no mínimo, duas incongruências:

i. A ausência de uma saída lógica que conteste a sua crença o que seria esperado por parte do terapeuta.

ii. A própria saída lógica absurda do ponto de vista do que sabemos ser verdade.

Por outro lado, como nas demais formas de humor, tais incongruências fazem sentido em um outro nível e não podem ser contestadas:

i. $\mathrm{O}$ fato de $\mathrm{o}$ terapeuta não contestar uma crença que $\mathrm{o}$ paciente esperava que ele contestasse faz sentido se compreendermos que o papel do terapeuta é justamente a condução de uma forma nova de pensar - não entrando "no jogo" do paciente.

ii. Por outro lado, a saída lógica proposta, ainda que incongruente na forma como é colocada pelo terapeuta, segue o movimento que o próprio paciente faz e, portanto, faz sentido em algum nível para ele e se torna apropriada.

Neste sentido, os paradoxos acima se constituem como um processo de incongruência-resolução característico do humor. Seu caráter terapêutico encontra-se na possibilidade de contemplar os mecanismos lógicos que fazem a crença absurda do paciente fazer sentido, sem 
deixar de propiciar um insight sobre sua absurdidade. Tal insight, por sua vez, provoca no paciente uma perspectiva distanciada sobre suas distorções e um contato maior com a totalidade de seus processos de vida, permitindo-o criar formas mais compreensivas de perceber e atuar sobre si mesmo e sobre o mundo à sua volta.

Contudo, para que esta comunicação seja vivenciada como humor e não como um comentário irônico ou agressivo, é necessário que ambos, terapeuta e paciente, adentrem o universo lúdico e vivenciem a estética humorada. Desta forma, também é fundamental que o terapeuta possua um senso de timing - pois se o paciente não estiver pronto para enxergar suas crenças e desdobramentos de forma distanciada e mais objetiva, não conseguirá perceber a incongruência de sua própria lógica.

Além disso, autores como Chazenbalk (2005), Kuhlman (1984), Rutherford (1994) e Sultanoff (2013) propõem que o humor em si também pode oferecer uma perspectiva alternativa, e até viabilizar uma reorganização mais profunda das crenças e autoafirmações disfuncionais do paciente. Este processo pode acontecer caso o humor permita um distanciamento destas crenças e valores, e, de fato, traga uma saída lógica criativa aos seus desdobramentos lógicos comuns. Tanto a linha de pensamento incomum - que gera a incongruência no humor - quanto o sentido que subjaz à mesma, tornando-a surpreendentemente apropriada, podem ser os pivôs desta mudança nas crenças e pensamentos.

c. Humor e insight: para Kuhlman (1984), o mecanismo utilizado no humor é o mesmo do insight. Segundo esse autor, a vivência do humor 
implica na resolução de uma incongruência, a qual requer uma solução de insight: uma nova ou expandida awareness da questão. Este insight, contudo, não é necessariamente terapêutico - depende de sua atuação com relação aos processos do sujeito e os objetivos visados. Ademais, o insight terapêutico pode emergir não só do mecanismo lógico que dá sentido à incongruência, mas de uma mensagem pessoal que este sentido emergente implique.

c) Humor e agentes comportamentais

a. Humor e aprendizagens em sentido geral: no que concerne a aprender a viver construtivamente, já ressaltamos o importante papel do desenvolvimento de um senso de humor por parte do terapeuta e do paciente. Além disso, as mensagens transmitidas pela expressão humorada, por mais descontraídas que sejam, podem consistir em profundas lições de vida (Greenwald, 1974).

b. Humor, condicionamento clássico, operante e aprendizagem social: segundo Kuhlman (1984), um dos motivos para a tardia emergência de uma popularidade nos estudos sobre o fenômeno humorado na psicoterapia corresponde a um prolongado tabu das ciências comportamentais com relação a fenômenos como amor, êxtase e humor. Entretanto, junto à abertura ao diálogo com os processos cognitivos (como, por exemplo, a utilização de imagens mentais), progressivamente o humor foi conquistando seu lugar também nas técnicas de condicionamento, como é o caso da dessensibilização sistemática, que discutiremos a seguir. Ademais, Kuhlman (1984) destaca que o riso de uma pessoa pode servir como reforço ao 
comportamento humorado de outra, bem como às crenças que subjazem a ele. De outra forma, conviver com pessoas bem-humoradas também pode contribuir para o aprendizado de atitudes humorísticas por parte do paciente.

c. Humor e extinção: conforme Kuhlman (1984), a expressão humorada dispersa a tensão, podendo ser uma ferramenta interessante na dessensibilização a um estímulo condicionado provocador de ansiedade e medo. Em outras palavras, o humor pode ser apresentado como novo estímulo a ser associado com o estímulo condicionado, extinguindo a associação prévia entre esse estímulo e as respostas de medo ou ansiedade.

Neste sentido, o autor destaca que o humor possui um potencial equivalente ou até maior que o relaxamento (estímulo proposto inicialmente na criação da técnica de dessensibilização e mais popular em seu uso). Isso porque o humor:

i. É um parente fisiológico do medo/ansiedade - todos eles implicam excitação fisiológica - diferentemente do relaxamento, que requisita uma resposta completamente diferente;

ii. É igualmente ou melhor manejável em comparação com o relaxamento;

iii. Atua possibilitando o distanciamento emocional dos estímulos condicionado e incondicionado, e a proposição de saídas lógicas criativas diante dos mesmos, permitindo a emergência de outras respostas emocionais. 
Com relação aos dois últimos casos, tanto Kuhlman (1984) como Smith (1974) ressaltam que a técnica de dessensibilização é feita por meio da construção de imagens do estímulo, ao invés do estímulo em si. Desta forma, eles admitem que é preciso levar em consideração a mediação de processos cognitivos nessa empreitada. Assim sendo, Smith (1974) ressalta o papel do humor na criação de uma nova perspectiva sobre a situação eliciadora de estresse, enquanto Kuhlman (1984) discute que o humor possibilita promover um desapego emocional das imagens do evento causador de estresse e oferecer uma nova saída lógica às deduções que se desdobram nestas imagens. Tal procedimento possibilita a emergência de processos alternativos em meio aos processos anteriormente hegemônicos, para os quais o sujeito não via saída.

d) Humor e agentes sociais (interpessoais, grupais e sistêmicos)

a. Humor e agentes grupais: na literatura aqui revisada, apenas Kuhlman (1984) aborda diretamente o uso psicoterapêutico do humor em contexto de grupo, embora Rutherford (1994) mencione os benefícios do compartilhamento de situações humoradas em sala de aula. Segundo Kuhlman (1984), o uso do humor no contexto grupal implica algumas considerações adicionais, dado que exige do terapeuta estar atento não somente a si mesmo e a um outro, mas a vários outros sujeitos e suas relações envolvidas na expressão e compartilhamento (ou não) do humor. Além disso, o humor também possui implicações específicas com relação à dinâmica de grupo. Algumas das considerações que o autor oferece sobre a emergência do humor neste contexto são: 
i. O caráter contagiante do riso: o compartilhamento do riso entre participantes pode acontecer por seu efeito contagiante. Deste modo, o motivo subjacente ao humor pode ficar em segundo plano, enquanto a risada dos outros ou o prazer do vínculo compartilhado tornam-se figura. Neste sentido, Kuhlman (1984) observa que o terapeuta deve estar atento, pois os participantes podem não estar rindo da expressão humorada em si e alguns podem nem sequer saber do que estão rindo.

ii. O compartilhamento da humanidade comum: o compartilhamento humorado entre os participantes diante de situações potencialmente embaraçosas ou comprometedoras pode conduzir a um sentido comum de humanidade - "todos nós fazemos/passamos por coisas difíceis, embaraçosas ou ridículas e não há problema nisso". Afinal, como já vimos, o senso de humor potencializa o sentimento de aceitação, pertencimento e coragem para ser imperfeito. Assim, Kuhlman (1984) ainda ressalta que um senso de humor por parte do terapeuta, humanizando-o, pode contribuir para evitar um movimento de infantilização do grupo (quando este endeusa o terapeuta e atribui a ele uma onipotência).

iii. Coerção grupal: o humor também pode ser utilizado pelo grupo como forma de coerção em resistir e evitar determinada questão que precise ser endereçada.

iv. Quando um membro do grupo direciona o humor a outro: o terapeuta deve estar atento às implicações da troca humorada 
entre os membros do grupo. Ele precisa estar aware com relação aos processos e vivências tanto daqueles que produzem este humor como daqueles a quem é endereçado, bem como às implicações desta manifestação das dinâmicas de grupo como um todo.

Com relação aos dois últimos casos, Kuhlman (1984) sublinha que é importante $o$ terapeuta não se aliar às manifestações coercitivas e nocivas de humor que aconteçam (rindo das mesmas ou acrescentando humor à situação), ao passo que também não é interessante que ele responda reativamente com hostilidade direcionada aos membros. Por outro lado, uma vez que o papel do terapeuta esteja bem definido, e o grupo tenha construído uma aliança de trabalho coesa, o autor acredita que quaisquer das formas de intervenção humoradas que se apliquem a uma terapia individual possam se aplicar ao contexto grupal.

b. Humor e agentes familiares: segundo Kuhlman (1984), muitas das dinâmicas de grupo que se adotam na terapia grupal, aplicam-se também à terapia de família, com um fator agravante nesta última enquanto no primeiro caso o terapeuta trabalha para forjar um "nós", na família este "nós" já existe, sendo o trabalho do terapeuta o de juntar-se ao mesmo. Tal condição tem implicações ao humor:

i. Por parte do terapeuta, o humor pode ser usado para "juntar-se" à família em um nível, enquanto intervém em outro. Contudo, o uso inicial do humor deve ser muito cauteloso: o terapeuta deve 
considerar as implicações da sua ação humorada em um momento em que ainda é considerado uma pessoa "estranha" ao grupo.

ii. Quando o terapeuta é admitido no grupo familiar, ele precisa considerar que ao direcionar o humor a um membro da família, este humor possui impacto nos demais e, ainda, que estes demais são mais próximos e mais prováveis de se aliar a este membro do que ao terapeuta.

iii. O terapeuta pode flexivelmente ficar do lado de um dos membros da família em sua lógica humorada, mas se essa tomada de lados se enrijecer pode ser muito perigoso para a aliança terapêutica e iatrogênico para a família.

iv. O terapeuta deve estar atento a alianças secretas e conversas laterais que aconteçam entre seus membros por meio do humor.

Adicionalmente, Chazenbalk (2005) afirma que o humor pode ser utilizado pelo terapeuta familiar para tirar o foco das discussões não construtivas entre os membros e encontrar outras alternativas para olhar o conflito.

c. Humor e agentes interpessoais: além das intervenções humoradas que acontecem no contexto interpessoal da terapia, alguns autores sugerem que o terapeuta recomende e incentive o paciente a buscar experiências humorísticas em contextos interpessoais fora da terapia (Cai et al., 2014; Jacobs, 2009; Sultanoff, 2013) - seja procurando por programas e apresentações humorísticas; encontrando pessoas bem-humoradas; ou 
em um exercício próprio para encontrar humor nas situações, por exemplo.

Nesta seção discutimos o uso do humor com relação aos agentes de mudança. Por fim, para que estes agentes possam acontecer e para que os objetivos da psicoterapia possam ser alcançados, são necessárias algumas condições básicas entre terapeuta e paciente. A seguir discutimos a relação do humor com os fatores terapêuticos comuns e fundamentais a todas as psicoterapias.

\subsection{Condições fundamentais à psicoterapia e humor}

Até o presente momento, discutimos o uso do humor na psicoterapia no que diz respeito aos meios psicológicos pelos quais ela se dá, seus objetivos específicos e os principais processos envolvidos na mudança que a mesma promove. Por fim, nesta seção, discutiremos as possíveis relações entre o fenômeno humorado e as condições básicas que viabilizam os processos de mudança no meio psicoterapêutico. Como vimos anteriormente, estas condições são apresentadas por Isolan et al. (2008) como: a) fatores do paciente; b) fatores do terapeuta; c) fatores do par terapeuta-paciente.

a) Humor e fatores do paciente

a. Humor e motivação: na literatura aqui abordada não existe nenhuma discussão específica sobre as contribuições do humor ao desejo e disposição do paciente em efetuar mudanças de vida na terapia. No entanto, a tomar pelo que discutimos até o momento, podemos assumir que o humor pode influenciar de algumas formas na motivação do paciente à mudança, por exemplo:

i. O humor, de forma geral, caso engaje os envolvidos e aborde questões importantes, pode mostrar ao paciente que suas 
dificuldades e problemas podem ser interpelados de maneira criativa e leve, potencializando sua motivação para abordá-los.

ii. Já o humor crítico pode se configurar como uma provocação saudável ao paciente que se encontra acomodado em sua forma de agir (apresentando pouca motivação à mudança).

iii. Além disso, o uso do humor por parte do paciente pode indicar tanto uma motivação à terapia - demonstrando sua disponibilidade ao diálogo e inclinação à mudança - quanto uma falta de motivação uma forma de evasão e de invalidação da proposta terapêutica.

b. Humor e as crenças e expectativas sobre a psicoterapia: na medida em que compreendemos que a estética humorada implica a celebração da capacidade de vida de se reinventar (vide capítulo 1), podemos assumir que o senso de humor por parte do terapeuta ou do paciente traz ao contexto da terapia um senso de esperança e confiança com relação à possibilidade de mudança. Porém, como a forma de utilizar esta estética varia, uma expressão humorada específica pode ser utilizada de forma "amarga" para transmitir a impossibilidade humana de mudança.

Já no que tange às crenças do paciente com relação a assumir os problemas como externos ou tomar responsabilidade sobre os mesmos, acreditamos que o humor possa contribuir tanto para uma evasão e culpabilização externa, quanto para um olhar voltado para si e potencialização na lida com suas questões.

c. Humor e facilidade para estabelecer uma relação terapêutica: o humor pode não só indicar ao terapeuta sobre a capacidade do paciente de estabelecer 
um vínculo e aliança terapêutica, como também intervir em algumas questões que estejam implicadas em sua dificuldade.

Segundo Rutherford (1994), as dificuldades de sentir-se seguro e de estabelecer um diálogo genuíno com o outro reverberam na difículdade do paciente de apreciar e utilizar o humor de forma apropriada. De acordo com essa autora, a falta de habilidade humorada pode indicar:

i. Que o paciente está muito distanciado do vínculo genuíno que conecta os seres humanos, e dos quais a expressão humorada saudável faz parte.

ii. Que a pessoa não está segura o suficiente para lidar com a mudança de equilíbrio que é própria do fenômeno humorado.

Com relação a este último caso, sabemos que o humor envolve processos paradoxais, mudanças de referência para um mundo lúdico e a subversão de valores que consideramos como verdades. Destarte, é compreensível que uma pessoa que esteja com o ego fragilizado e com seu senso de Self debilitado perceba o humor como uma verdadeira ameaça à sua integridade, fechando-se para esta troca.

Portanto, a dificuldade de apreciação do humor pelo paciente pode indicar um ego fragilizado e oferecer um mau prognóstico sobre sua capacidade presente de estabelecer um vínculo e uma aliança de trabalho. Entretanto, como já discutido, o humor também pode contribuir para a construção de um Self mais coeso e integrado e, consequentemente, para a abertura a um vínculo genuíno.

Além disso, é importante destacarmos que a troca humorada pode indicar uma boa capacidade do paciente para estabelecer vínculos, mas não 
necessariamente uma aliança de trabalho produtiva - o paciente pode desenvolver um bom vínculo com o terapeuta e ainda assim ter dificuldade de colaborar com o trabalho terapêutico.

d. Humor e grau de sofrimento psíquico: é importante que o paciente apresente certo grau de desconforto que o conduza à necessidade de mudança. Contudo, um elevado grau de sofrimento psíquico pode dificultar o processo terapêutico.

Neste sentido, o uso do humor que dispense o paciente de se implicar em questões terapêuticas importantes - ao mesmo tempo produzindo sensações de leveza e prazer - pode diminuir de tal modo o grau de desconforto do paciente que impossibilite seu acesso às demandas para terapia. Já o humor crítico e demais formas humoradas que driblem uma possível postura evasiva do paciente podem potencializar este desconforto e, consequentemente, a necessidade de mudança.

Entretanto, um excessivo grau de sofrimento impossibilita a vivência humorística. Rutherford (1994) aponta que a impossibilidade do paciente de apreciar trocas humoradas encontra-se relacionada com sua dificuldade de sentir-se feliz e de compartilhar momentos prazerosos. Cai et al. (2014), por sua vez, relacionam esta impossibilidade à severidade dos sintomas psicopatológicos em casos de sofrimento psíquico grave.

e. Humor e grau de tolerância à ansiedade: como um baixo grau de tolerância à ansiedade pode dificultar os processos terapêuticos, o humor pode ser uma importante ferramenta terapêutica, uma vez que ele pode:

i. Atuar diminuindo as respostas de estresse; 
ii. Tratar de assuntos ansiogênicos de forma leve e descontraída, considerando a dificuldade do paciente.

Por outro lado, se o humor for vivenciado, de alguma forma, como insultivo ou agressivo; bem como se este humor tratar de um tema muito ameaçador, a baixa tolerância à ansiedade pode tornar o episódio humorado ainda mais intolerável e iatrogênico.

f. Humor e habilidade de resolução de problemas: de acordo com o que já discutimos, o humor pode contribuir para o desenvolvimento da capacidade do paciente de resolução de problemas. Contudo, ele também exige que certas habilidades estejam presentes por parte do paciente.

Neste sentido, Cai et al. (2014) afirmam que o prejuízo em algumas habilidades neurocognitivas básicas do paciente pode comprometer seu reconhecimento e apreciação do humor. Do mesmo modo, Sultanoff (2013) ressalta que a rigidez das estruturas cognitivas e emocionais do sujeito também pode contribuir para uma dificuldade ou ausência de apreciação e criação humorística.

Assim sendo, a falta de habilidade humorada do paciente ou sua impossibilidade de apreciar o humor também pode diagnosticar sobre a capacidade atual do mesmo para resolução de seus problemas.

g. Humor e grau de reatividade emocional: qualquer compartilhamento humorado envolve certo grau de reatividade emocional. Por outro lado, a ausência da apreciação ou da capacidade de criar humor por parte do paciente pode ser indício de processos repressores (Rutherford, 1994) envolvendo um estilo de vida que reprima processos lógicos primários, e cuja rigidez com relação aos valores dificulte um movimento de subversão. 
Também as manifestações humoradas inapropriadas (não compartilhadas) podem demonstrar um baixo grau de reatividade emocional na troca com os demais. Esta ausência ou inadequação do humor podem se configurar como um mal prognóstico quanto à disponibilidade do paciente para ser influenciado.

b) Humor e fatores do terapeuta

a. Humor e autenticidade: o desenvolvimento do senso de humor do terapeuta contribui para uma postura autêntica por parte do mesmo. Afinal, como vimos anteriormente, a estética humorada enquanto forma de vida implica, dentre outras coisas, uma relação mais honesta com a realidade, uma coragem para ser imperfeito e uma maior inteireza de Self no contexto presente.

Por outro lado, quando o terapeuta leva a si mesmo e ao seu empreendimento muito a sério, é possível que ele tome uma postura mais rígida e retraída consigo, dificultando sua espontaneidade. Neste sentido, Jacobs (2009) afirma que ao escolher a seriedade, em detrimento do senso de humor, o psicoterapeuta acaba cerceando também seus recursos, tais como: a habilidade de pensar literalmente, sua curiosidade, seu desprendimento para engajar-se ludicamente, e sua fé de que a situação seja resolvível.

Como discutimos anteriormente, esta falta de autenticidade por parte do terapeuta pode resultar, ainda, em expressões humoradas que funcionem mais aos seus próprios propósitos de encobrir determinado desconforto ou dificuldade, do que aos interesses terapêuticos voltados ao paciente. 
A autenticidade presente no contexto humorado, por sua vez, pode criar uma atmosfera de liberdade e abertura que favoreça expressões mais espontâneas e autênticas por parte do paciente (Chazenbalk, 2005; Richman, 1996).

b. Humor e calor humano: o calor humano é fundamental para que o terapeuta utilize o humor de forma terapêutica (Sultanoff, 2013). Kuhlman (1984) ressalta que qualquer manifestação humorística do terapeuta, por mais crítica que pareça, deve possuir carinho, preocupação e respeito subjacentes. Do mesmo modo, Greenwald (1975) enfatiza que o humor do terapeuta deve ser baseado em seu carinho pelo paciente e apreciação de suas forças e habilidades.

c. Humor e empatia: a importância da empatia no uso do humor parece ser uma unanimidade entre os autores e estudiosos da psicoterapia (Greenwald, 1975; Kuhlman, 1984; Kupermann, 2003; Panichelli, 2013; Richman, 1996; Sultanoff, 2013).

Nas palavras de Greenwald (1975), eu devo enfatizar a importância de realmente entender a pessoa se você usar humor em sua sessão. Porque se você não entende, o humor pode ser destrutivo. Pode ser ridicularizante, pode ser cínico, pode ser doloroso. Por outro lado, se você tentar ver o mundo, como eu tento fazer o tempo todo, pelo olhar deles [pacientes], não há esse efeito (p. $115)$.

Nesta direção, Panichelli (2013) afirma que a habilidade do terapeuta de ver o mundo através dos olhos do paciente é fundamental para que as mudanças de perspectiva propostas pela intervenção humorada reconheçam este olhar 
e façam sentido para o paciente. Kuhlman (1984) também afirma reiteradas vezes a importância do que ele chama de "trilha empática" para que o terapeuta saiba quando se expressar humoristicamente.

Richman (1996) vai mais longe: afirma que geralmente o terapeuta consegue ocultar quando está mais preocupado consigo mesmo e com seus interesses pessoais do que com o paciente e os objetivos terapêuticos; mas diante da "clareza microscópica" do humor - um fenômeno que envolve a emergência de processos implícitos e implica profundas camadas de sentido - este desvio de foco do terapeuta pode se tornar particularmente evidente. Desta forma, o autor assevera que o uso bem-sucedido do humor não pode acontecer sem um relacionamento empático entre terapeuta e paciente.

d. Humor e outros aspectos importantes: com relação a outros fatores gerais do terapeuta que possam ser importantes para o sucesso do empreendimento psicoterapêutico, o humor é tido pelos autores como contribuindo para:

i. Cultivar a criatividade e imaginação (Chazenbalk, 2005; Rutherford, 1994).

ii. Manter viva a postura de curiosidade do psicoterapeuta (Jacobs, 2009).

Além disso, o senso de humor do terapeuta pode contribuir para que não se sinta sobrecarregado ao lidar diariamente com histórias de sofrimento (Jacobs, 2009), prevenindo um burnout profissional (Panichelli, 2013).

c) Humor e fatores do par terapeuta-paciente

a. Humor e o desenvolvimento de uma aliança terapêutica: diversos estudiosos acreditam que o humor possa ajudar a criar uma aliança terapêutica na clínica psicológica (Chazenbalk, 2005; Kuhlman, 1984; Rutherford, 1994; 
Sultanoff, 2013). Chazenbalk (2005) afirma que o humor auxilia na criação de um rapport entre terapeuta e paciente, ao passo que Rutherford (1994) aponta a interação humorada como facilitadora de uma mutualidade na relação.

Neste sentido, Kuhlman (1984) discute a importância de que o paciente reconheça e aceite a brincadeira humorística proposta pelo terapeuta, de modo que ambos possam usufruir da troca humorada. Desta forma, é possível afirmar que a troca humorada entre sujeitos implica algum tipo de aliança, embora não necessariamente terapêutica - uma vez que sua qualidade terapêutica se define apenas no direcionamento desta cooperação para os objetivos acordados em psicoterapia.

Por outro lado, quando aspectos desta aliança terapêutica (i.e.: objetivos, tarefas, ou qualidade do vínculo) ainda não estão muito bem definidos, a apresentação do humor em terapia pode gerar antagonismos ou malentendidos entre terapeuta e paciente que dificultem ainda mais a construção de uma aliança (Kuhlman, 1984).

b. Humor e o desenvolvimento de um vínculo: Richman (2001) afirma que o humor deve ser baseado no cuidado com o paciente e no desejo por sua melhora, ambos frutos da natureza humana do relacionamento terapeutapaciente, mais do que da relação puramente formal-profissional. Neste sentido, Sultanoff (2013) argumenta que o vínculo afetivo entre as pessoas do terapeuta e do paciente é que devem modular o "tom" do humor utilizado em terapia.

Além disso, Kuhlman (1984) afirma que o estabelecimento de uma relação jocosa em terapia constitui um marcador simbólico de intimidade entre 
terapeuta e paciente. Contudo, este sentido de intimidade e o prazer da troca lúdica podem dissolver os limites profissionais entre terapeuta e paciente, sobrepondo-se aos propósitos terapêuticos subjacentes à formação deste relacionamento. À vista disto, o autor enfatiza a importância de que o terapeuta mantenha seu papel profissional e seu trabalho nas trocas humoradas com o paciente, de modo que ambos estejam cientes de que a interação íntima de um relacionamento jocoso corresponde a uma conexão, porém não a um envolvimento.

c. Humor e a transferência: na literatura abordada nesta dissertação com relação ao uso do humor na psicoterapia, não há muita discussão sobre a interação dos fenômenos humorados com os aspectos transferenciais da relação. Entretanto, Kuhlman (1984) ressalta que o terapeuta deve estar atento a estes aspectos: o uso do humor por parte do terapeuta pode tornarse ofensivo ainda que tenha boas intensões e consista em uma estratégia coerente, posto que a história do paciente e a figura transferencial que o terapeuta assume para o mesmo podem trazer significados negativos a esta troca humorada. Em contrapartida, Zanello (2005) destaca que o humor possui o potencial de favorecer uma transferência positiva na relação terapêutica, uma vez que seu uso pode criar uma atmosfera relacional de leveza e acolhimento sem abrir mão da intervenção.

Uma vez estabelecida e observada a relação transferencial, Kuhlman (1984) afirma que o humor tanto pode atuar em seu uso terapêutico, como pode ser utilizado para "corrigir" suas distorções - mostrando ao paciente a humanidade e singularidade do terapeuta. 
Esta seção visou discutir o fenômeno humorado com relação aos fatores que se constituem enquanto condições básicas aos diversos empreendimentos psicoterapêuticos. Como pudemos observar, o humor neste contexto se apresenta não apenas de forma interventiva, mas também diagnóstica.

Além da relação direta que o humor estabelece com os mais diversos aspectos que permeiam a atuação psicoterapêutica, sua emergência neste contexto também se relaciona, de modo mais geral, com os paradigmas que permeiam a clínica psicológica. O próximo, e último, tópico deste capítulo discutirá brevemente sobre esta questão.

\subsection{O humor e a mudança de paradigma na clínica psicológica}

Diversos autores têm associado o humor a mudanças de paradigma na clínica psicológica. As três modificações principais que identificamos na literatura são:

a) Do paradigma voltado à doença para o paradigma voltado à saúde;

b) Do paradigma voltado à ideologia da seriedade para o paradigma voltado ao senso de humor;

c) Do paradigma cientificista para o paradigma estético.

A seguir discutiremos a relação do humor com cada uma dessas mudanças.

a) Do paradigma voltado à doença para o paradigma voltado à saúde.

O humor é um dos fenômenos primários da vida humana. Como temos discutido, o fenômeno humorado faz parte da nossa natureza, mostrando-se presente nas interações desenvolvidas nas mais diversas culturas através dos tempos (Oring, 2008; Tanay et al., 2012). Entretanto, como Jacobs (2009) aponta, embora rir e chorar sejam duas expressões emocionais inatas básicas, psicoterapeutas têm estado muito mais interessados no fenômeno do choro do que no riso. 
Esta disparidade de interesses se relaciona diretamente com a predominância de um paradigma científico voltado à patologia, noção que por muito tempo dominou o cenário das construções teóricas e práticas da psicologia (Chazenbalk, 2005; Neubern, 2004). Neste sentido, a recente emergência do humor em trabalhos e estudos clínicos, bem como sua valorização no contexto psicoterapêutico estão relacionadas a uma mudança significativa no paradigma psicológico: do foco na doença e dificuldade, para ênfase na saúde e nos recursos humanos.

Segundo Chazenbalk (2005), o surgimento de um paradigma que acentue os processos saudáveis de uma pessoa ou grupo traz para o centro das discussões as experiências alegres, prazerosas, otimistas e solidárias que outrora faziam plano de fundo à patologia. Tais experiências passam a ser compreendidas como recursos pessoais que podem não só oferecer proteções naturais frente às adversidades, como também permitir a construção de uma perspectiva mais saudável frente a acontecimentos difíceis. Diante desta nova lógica clínica, o fenômeno humorado se torna um importante recurso terapêutico.

b) Do paradigma voltado à ideologia da seriedade para o paradigma voltado ao senso de humor.

Diferentemente dos demais recursos e vivências prazerosas, a aceitação do humor também enfrenta dificuldades relacionadas a outro paradigma. Como vimos no capítulo 1 , o humor é um desafio à ideologia da seriedade que permeia não apenas os meios acadêmicos como o nosso próprio cotidiano (Neves, 1974). Nesta direção, Kuhlman (1984) atribui a emergência tardia dos estudos e debates sobre o humor na psicoterapia ao dogmatismo que predominava nas discussões clínicas e científicas da época. O autor afirma que a emergência dos debates e da validação do uso do humor na clínica psicológica só se tornou possível quando os estudos psicológicos passaram a reconhecer a 
importância de qualidades humanas como empatia, flexibilidade, espontaneidade e criatividade, independentemente da orientação teórica adotada (Kuhlman, 1984).

Entretanto, ainda hoje é possível observarmos uma visão preconceituosa com relação ao humor, devido ao seu caráter lúdico e ambíguo - tido pela ideologia da seriedade como indicador de descomprometimento e imaturidade (Neves, 1974). Assim sendo, muitos psicoterapeutas ainda tendem a uma postura "séria" - sisuda, rigorosa e distanciada - como se esta fosse sinônimo de comprometimento, precisão e profissionalismo, apresentando uma rigidez pouco saudável à troca terapêutica (Greenwald, 1975; Jacobs, 2009; Kuhlman, 1984).

Destarte, o senso de humor em psicoterapia é fundamental para combater esta postura e desmistificar esta ideologia, mostrando que nosso sentido de responsabilidade e nosso diálogo com a realidade podem ser potencializados por uma forma aberta, autêntica, flexível e divertida de se colocar no mundo. Nesta direção, assumir a centralidade do senso de humor na psicoterapia pode significar o início de uma mudança de paradigma clínico: de uma ideologia da seriedade para uma ideologia do humor.

c) Do paradigma cientificista para o paradigma estético.

A vivência humorada na clínica psicológica não conduz apenas a uma mudança de paradigma da seriedade para o senso de humor. Segundo Kupermann (2003), a emergência do humor no setting psicoterapêutico e as considerações do mesmo enquanto importante ferramenta na clínica psicológica obrigam os terapeutas a considerarem a dimensão estética da psicoterapia, em detrimento da racionalidade e linearidade científicas.

Como vimos no primeiro capítulo, a experiência humorada é um acontecimento eminentemente estético: o humor implica complexos processos e qualidades que se dão apenas por meio da própria vivência humorada. Desta forma, o desejo de construir trocas humoradas na psicoterapia coloca um problema aos terapeutas: se por um lado, falamos do 
uso deliberado do humor como ferramenta terapêutica; por outro, sabemos que a emergência do humor não pode ser diretamente controlada (Chazenbalk, 2005; Kuhlman, 1984; Rutherford, 1994). Neste sentido, Kupermann (2003) afirma que a razão lúdica humorística nos lembra a todo momento que a vida psíquica não é regida única e exclusivamente pela lucidez unidimensional moldada pelo cientificismo moderno. Em outras palavras, o humor remete a uma parte significativa da psicoterapia que não pode ser desenvolvida apenas por meio de informações e execuções técnicas.

Assim sendo, esse autor (Kupermann, 2003) afirma que a consideração do uso do humor por parte do terapeuta introduz uma mudança no cerne da psicoterapia: do paradigma cientificista ao paradigma estético. A psicoterapia passa a ser compreendida também como uma forma de arte (Hycner, 1995; Zeig, 2015), lidando com processos que vão a cabo no próprio meio vivido em que as pessoas se encontram - envolvendo intensidades, afetos, atitudes e experiências que não podem ser acessadas diretamente pelo discurso ou transmitidas por regras técnicas.

Esta mudança de paradigma coloca novas questões aos estudos e às práticas psicológicas, tais quais: uma vez que não bastam os conhecimentos teóricos e as técnicas objetivas, como o terapeuta desenvolveria a sensibilidade e a criatividade para construir experiências terapêuticas na relação? Como ele pode aprender características e habilidades estéticas importantes à psicoterapia, tais como empatia, timing, aceitação e, inclusive, senso de humor? E, ainda, a questão que será endereçada no terceiro capítulo deste trabalho: como o psicoterapeuta pode aprender a criar intervenções humoradas, de forma intencional e sensível?

Deste modo, vemos que o fenômeno humorado não se relaciona apenas com aspectos específicos de uma atuação psicoterapêutica, mas com os alicerces de sua constituição. Segundo discutimos nesta última seção, qualquer terapeuta que cogite utilizar 
o humor em sua práxis psicoterapêutica deve passar por uma mudança de paradigmas em sua própria forma de pensar a clínica.

\subsection{Considerações finais}

Este capítulo propôs-se a construir uma visão compreensiva acerca das implicações do fenômeno do humor à práxis psicoterapêutica.

O uso do humor na clínica psicológica tem sido muito valorizado nos últimos tempos, mas os mesmos motivos que pautam sua valorização também motivam sua marginalização: seu caráter lúdico, ambíguo e subversivo, bem como seu forte potencial de envolvimento e transmissão de mensagens, os quais o configuram como uma ferramenta terapêutica muito poderosa, mas também muito destrutiva.

Em face deste dilema, muitos estudiosos têm argumentado que as qualidades terapêuticas subjacentes a uma troca humorada saudável são as mesmas necessárias para as demais trocas forjadas em psicoterapia. A questão não seria banir ou não o humor da clínica, mas como e quando utilizá-lo.

Assim sendo, é importante que o psicoterapeuta conheça as particularidades do relacionamento entre o fenômeno humorado e os diferentes aspectos que constituem a clínica psicológica, a fim de que possa desenvolver uma maior awareness sobre os riscos e potenciais particulares de sua presença neste contexto.

Neste capítulo discutimos que a expressão humorada pode ser direcionada de forma terapêutica ou não, mas que o senso de humor - enquanto uma forma básica de se situar no mundo - é essencialmente terapêutico e potencializa muitos dos processos fundamentais à uma psicoterapia bem-sucedida. Neste sentido, o senso de humor é tido por muitos autores não apenas como um objetivo central de qualquer psicoterapia, mas também como uma 
postura necessária ao psicoterapeuta (Chazenbalk, 2005; Greenwald, 1975; Jacobs, 2009; Kuhlman, 1984).

Entretanto, as compreensões até aqui desenvolvidas não são suficientes para que o psicoterapeuta desenvolva seu senso de humor. Como vimos, as habilidades criativas e a sensibilidade humorísticas não podem ser ensinadas apenas por meio de informações lógicas ou regras metodológicas. Desta forma, somos conduzidos às seguintes questões: como o psicoterapeuta pode desenvolver o seu senso de humor na clínica? Como pode aprender a criar intervenções humoradas de forma intencional e sensível?

Estas são as temáticas que abordaremos no próximo capítulo. 


\section{Capítulo 3 - É possível desenvolver o senso de humor do psicoterapeuta? Como?}

O fenômeno humorado possui um lugar de destaque no contexto da psicoterapia. Como vimos no capítulo anterior, o senso de humor, como uma forma geral de se situar no mundo e nas relações, ocupa um papel central no paradigma clínico: consiste em uma postura fundamental a ser desenvolvida pelo psicoterapeuta, bem como em um dos objetivos desejáveis de qualquer psicoterapia. Além disso, trocas humoradas pontuais podem se configurar como importantes ferramentas no engendramento de processos terapêuticos específicos. Não obstante, o fenômeno do humor não é inerentemente saudável, e seu potencial de mobilização pode ser direcionado para trocas igualmente destrutivas.

Por conseguinte, muitos dos estudiosos que discutem sobre o lugar do humor na psicoterapia consideram importante que o psicoterapeuta não apenas compreenda as implicações do fenômeno humorado nas especificidades de seu trabalho, como também desenvolva suas habilidades humorísticas, a fim de que possa exercer domínio sobre o uso do humor no contexto clínico (Richman, 1996; Saper, 1987; Sultanoff, 2013). Neste sentido, diversos desses trabalhos consideram a criação do humor como passível de intencionalidade, de modo que um psicoterapeuta proficiente seria capaz de forjar trocas terapêuticas humoradas como e quando o desejasse (Jacobs, 2006; Kuhlman, 1984; Panichelli, 2013; Richman, 1996; Rutherford, 1994; Sultanoff, 2013).

No entanto, ainda que seja comum na literatura psicoterapêutica o cômico ser abordado enquanto uma técnica - como se pudesse ser conscientemente aplicado, controlado e previsto - (Prerost, 1984; Rutherford, 1994; Smith, 1973; Sultanoff, 2013), a realidade de sua emergência é muito mais complexa. Como discutimos nos capítulos anteriores, o humor consiste em um fenômeno intersubjetivo: ele acontece na relação do 
sujeito com o mundo, de modo que se constitui enquanto parte integral das atividades e formas de vida do ser humano - envolvendo os complexos processos culturais, sociais, emocionais, cognitivos, simbólicos e cinestésicos que dela fazem parte. Desta forma, o desejo de desenvolver uma intencionalidade no uso do humor nos coloca diante de alguns problemas centrais:

a) O terapeuta não tem completo controle sobre a criação do humor: enquanto fenômeno intersubjetivo, a emergência do humor depende dos sujeitos envolvidos e da qualidade da relação que se estabelece entre eles. Assim sendo, a troca humorada envolve ambos, terapeuta e paciente ativamente, tornando inviável atribuir completo controle e predição a uma das partes.

b) Esforçar-se para criar o humor sem ser humorado é infrutífero: enquanto uma atividade ou forma de vida, o humor pode ser vivenciado apenas por meio de sua própria realização. Em outras palavras, os processos e sentidos do humor não podem ser viabilizados senão pela própria experiência humorada. Desta forma, o humor não pode ser realizado através de um esforço sério e racional - o qual pode, inclusive, inviabilizá-lo -, afinal: ou estamos engajados no processo racional de querer fazer graça, com todas as nossas emoções e pensamentos investidos nessa preocupação; ou estamos engajados no processo humorado.

c) Informações e execuções técnicas são insuficientes para nos permitirem acessar e desenvolver a capacidade humorística: enquanto fenômeno emergente de uma complexa relação entre processos culturais, sociais, emocionais, cognitivos, simbólicos e cinestésicos, o humor é multifacetado e envolve níveis de experiência que não podem ser acessados somente pelo nível do raciocínio consciente. Consequentemente, a lógica racional e linear das informações e execuções técnicas é insuficiente para permitir um maior domínio sobre o fenômeno humorado. 
Diante das condições enumeradas acima, podemos nos questionar: Seria possível desenvolvermos intencionalmente um fenômeno essencialmente vivencial que envolve processos tão inacessíveis ao nosso controle direto e racionalidade consciente?

Autores como Burnier (2009), Camargo (2012) e Oliveira (2008) sugerem que sim. Porém não da forma séria, controlada e preditora com que a racionalidade científica moderna tenta apreender os fenômenos.

Para desenvolvermos nossa capacidade humorística, de modo que possamos fazer uso intencional da mesma, é preciso que nos coloquemos abertos ao diálogo com outros tipos de saberes e formas de produção de conhecimento (Oliveira, 2008). Nas palavras de Mota,

(...) diversas estratégias interpretativas têm procurado uma aproximação mais esclarecedora da comicidade. A compreensão dessas estratégias e de seus limites possibilita não só um conhecimento da comicidade e sim de nossas formas de apropriação da realidade. $\mathrm{Na}$ verdade, tentar conhecer a comicidade mostra como produzimos conhecimento. Ao invés de um passivo alvo de investigação, este variacional e multifocal objeto explicita seu intérprete. Aprender a comicidade é compreender atos e situações de conhecimento (citado por Oliveira, 2008, p. 20).

Desta forma, nosso questionamento passa a ser: Como se dá o aprendizado da comicidade e o desenvolvimento de uma intencionalidade em seu uso?

Como já discutimos, o humor é um fenômeno inter-humano. Segundo Hycner (1995), só podemos acessar os fenômenos inter-humanos nos momentos de diálogo genuíno com o mundo, pois é na vivência deste "entre" que emergem tais experiências. Deste modo, aprender a eliciar e manejar um determinado fenômeno inter-humano significa aprender a estabelecer uma determinada forma de diálogo com o mundo. Este 
aprendizado, segundo o autor, se dá por meio da incorporação das qualidades relacionais que constituem esta forma de diálogo.

Para Zeig (2015), a incorporação de determinadas qualidades relacionais por parte do sujeito corresponde ao desenvolvimento de um "estado", isto é, uma forma de ser e estar no mundo. Segundo este autor, o domínio de um estado e de suas qualidades relacionais, mais do que um conhecimento puramente intelectual ou técnico, corresponderia a um “conhecimento corporificado" (p. 9).

Esse conhecimento corporificado, segundo Burnier (2009), diz respeito não apenas a uma fisicidade - o que o corpo faz - mas especialmente a uma corporeidade - como o corpo faz. Em outras palavras, mais do que um conjunto de habilidades e ações físicas, o conhecimento corporificado consiste nos sentidos incorporados nas ações, isto é, em uma lógica corporificada na forma como o corpo atua e intervém no espaço e no tempo, como ele sente e percebe o mundo, como age e reage nele.

Nesta perspectiva, para aprendermos a eliciar e manejar a emergência do humor na relação, precisamos aprender a acessar e desenvolver nosso "estado cômico", isto é, encontrar meios que nos permitam exercitar o modo de ser e de pensar cômico e as qualidades relacionais que nele se encontram incorporadas.

Mas quais seriam estes meios?

Autores como Burnier (2009), Oliveira (2008) e Zeig (2015) acreditam que exista apenas um caminho: o da prática. Zeig (2015) chega a comparar o descobrimento e desenvolvimento de estados internos com o aprendizado de andar de bicicleta:

Aprender a andar de bicicleta é uma experiência visceral baseada em um aprendizado procedural implícito (...) memorizar a fórmula física de andar de bicicleta não te ajuda a permanecer balanceado e deslizar através do espaço. Você aprende a dirigir em seu corpo. Para aprender o conceito de momentum, você tem 
que estar na bicicleta tentando manter seu equilíbrio, desenvolvendo uma awareness implícita de todos os modos que seu movimento corporal afeta a direção e estabilidade (p. 34).

Para esse autor, é somente através das experiências que o sujeito pode ir descobrindo e afiando seus estados internos, desenvolvendo uma awareness implícita para todos os sentidos, qualidades e nuances que o constituem. Nesta direção, tanto Zeig (2015) como Burnier (2009) acreditam em uma espécie de atletismo afetivo: treinamentos cujas experiências não somente forjem um determinado estado nos sujeitos, mas permitam a eles o desenvolvimento de uma compreensão visceral (awareness) de suas particularidades, tornando-os proficientes em seu uso.

Da mesma forma, Oliveira (2008) também defende o treinamento como forma de chegar ao domínio de um estado. Para esse autor, são as experiências do treinamento que nos levam a criar e conhecer as possibilidades de utilização do nosso próprio corpo e dos diversos estados que o habitam.

O desenvolvimento de um conhecimento visceral do estado cômico por meio de um treinamento específico, por sua vez, pode conferir ao sujeito a capacidade de criar intencionalmente o humor (Burnier, 2009; Oliveira, 2008).

Contudo, faz-se importante destacar que esta intencionalidade:

a) também é visceral: envolve conhecimentos e direcionamentos corporificados, de modo que não diz respeito a uma intenção meramente racional. Assim como andar de bicicleta e desviar de um buraco não contam apenas com a intencionalidade intelectual - pois envolvem uma complexa interação e ajuste de vetores, direcionamentos e posturas corporais sobre os quais não temos controle consciente -, também a criação proposital do humor envolve uma 
intencionalidade permeada por processos, direcionamentos e sentidos viscerais, desenvolvidos no treinamento humorado.

b) Não permite o controle direto sobre a emergência da experiência humorada na relação. Compreendendo o humor como um fenômeno inter-humano, esta intencionalidade consiste apenas em uma habilidade e sensibilidade do sujeito para fazer proposições humoradas na relação, e não na possibilidade de controlar a emergência do humor.

Em outras palavras, não é possível que o psicoterapeuta controle racionalmente as trocas humoradas, mas é possível que ele desenvolva, através de práticas e treinos, maior sensibilidade e habilidade para propô-las nas interações com seus pacientes.

Neste sentido, Franzini (2001) afirma que as oportunidades de treino formal com relação à criação e ao desenvolvimento do humor podem permitir ao terapeuta uma maior familiaridade com este fenômeno, de modo que seu uso espontâneo se torne mais provável e seu saber "intuitivo", sobre quando utilizá-lo, mais desenvolvido. Entretanto, essa autora ressalta que, ainda que muitos psicoterapeutas discutam o uso do humor na clínica psicológica, é quase nula a parcela deles que se debruça sobre como os terapeutas poderiam aprender a usar o humor em sua prática. Do mesmo modo, autores como Kuhlman (1984), Richman (1996) e Sultanoff (2013) também criticam a ausência de proposições concretas sobre como o psicoterapeuta poderia desenvolver sua capacidade e sensibilidade cômicas.

Uma vez que nos propusemos a discutir neste trabalho sobre o uso do humor na psicoterapia, e dada a escassez de trabalhos que tratam das possibilidades práticas de desenvolvimento das habilidades humoradas do psicoterapeuta, este capítulo se propõe a explorar as possibilidades de desenvolvimento da capacidade cômica do psicoterapeuta sob o prisma de uma arte cômica particular: a palhaçaria. 
Visto que a figura do palhaço se encontra, atualmente, bastante banalizada (Dario Fo, 2004; Lecoq, 2010), faz-se importante destacar que a arte da palhaçaria remete a toda uma complexidade de treinamentos, estudos e práticas que possibilitam à pessoa o desenvolvimento de uma sensibilidade cômica muito refinada, de modo que não se refere apenas à caracterização usual do palhaço (maquiagem carregada, nariz vermelho, etc.) e à mera tentativa de entretenimento.

Como veremos mais adiante, o palhaço a que nos referimos é uma figura antiga, que remonta ao surgimento dos seres humanos enquanto sociedade, e está muito mais relacionada ao descobrimento e aguçamento de um estado cômico pessoal do que à mera representação ou apresentação de truques (Assis, 2010; Burnier, 2009). Neste sentido, ele não diz respeito a um personagem, mas a um modo de ser e de pensar essencialmente cômico que existe desde os primórdios da humanidade e que tem encontrado formas e lugares de expressão diferentes ao longo do tempo, sobrevivendo a diferentes culturas, gêneros teatrais, sofisticações literárias e mudanças sociais através dos tempos (Dario Fo, 2004; Dorneles, 2003; Langer, 1953).

Desta forma, partimos do pressuposto de que a arte da palhaçaria, transmitida e desenvolvida ao longo da história, pode servir como importante ferramenta na viabilização de um contato profundo com a natureza cômica do ser humano. O objetivo deste capítulo é explorar como as qualidades, atitudes e estados implicados no treinamento de palhaço podem contribuir para o desenvolvimento de um senso de humor aguçado por parte do psicoterapeuta.

\subsection{Quem é o palhaço?}

Não existe uma definição ou teoria única sobre o palhaço. Por ser uma arte popular, a palhaçaria tem sido transmitida ao longo dos séculos majoritariamente por meio de 
experiências forjadas na convivência entre aspirantes a palhaço e palhaços mais experientes (Burnier, 2008; Camargo, 2012; Dorneles, 2003). Neste sentido, Camargo (2012) ressalta que ainda há poucas pesquisas dedicadas especificamente à linguagem do palhaço, bem como poucas teorias sistematizadas que permitam maior inteligibilidade sobre as particularidades desta figura. Além disso, considerando a existência do palhaço nas mais diversas culturas e sociedades, é compreensível que diferentes linhas de trabalho e aprendizado tenham se desenvolvido ao longo do tempo. Camargo (2012), então, observa: “O universo da palhaçaria é amplo e suas funções não são tão claras quanto parece" (p. 35).

Assim sendo, a fim de que possamos refletir sobre as possíveis contribuições da palhaçaria para o desenvolvimento do senso de humor do psicoterapeuta, dedicaremos as próximas seções deste capítulo ao esclarecimento sobre a forma como compreendemos a figura do palhaço: suas raízes históricas, as principais qualidades e especificidades que constituem sua linguagem, e as particularidades de seu treinamento.

\subsection{O palhaço e suas raízes na história da humanidade}

A palhaçaria é uma arte milenar que tem encontrado lugar em diferentes momentos, espaços e sociedades através dos tempos (Matraca et al., 2011). Seus contextos de ocupação variam: ruas, festas, rituais, circos, teatros, escolas, hospitais e até filmes e animações (Berky \& Barbre, 2000; Burnier, 2009; Koller \& Gryski, 2007). Segundo autores como Burnier (2009) e Dario Fo (2004), os palhaços aparecem nas apresentações populares de todos os tempos e países: das comédias de Aristófanes na Antiguidade ao teatro chinês moderno. Em toda a história, sua figura tem sido apreciada pelas diferentes classes sociais e faixas etárias (Dorneles, 2003). 
Neste sentido, Matraca et al. (2011) ressaltam que esta arte tem se personificado em diferentes nomes e tipos a depender do momento histórico, da sociedade e do contexto em que se materializa - sendo alguns exemplos: o Hotxuá para os índios brasileiros Krahô; o Vidushaka na Índia; o Bufão na Itália; e o Danga no Egito. Atualmente, na cultura ocidental moderna, esta arte encontra-se encarnada principalmente na persona que chamamos de palhaço ou clown.

Segundo Burnier (2009), a palavra "palhaço" vem da palavra italiana "paglia" (palha) e surge em referência à roupa primitiva desta figura na Itália: não só feita com o mesmo pano utilizado para revestir colchões de palha, como preenchida com palha em certas partes para evitar contusões durante as quedas e acrobacias (Dorneles, 2003). Já a palavra "clown" vem do inglês "clod", que significa "estúpido", "bronco" (Burnier, 2009; Dorneles, 2003).

Malgrado a diferença nas origens etimológicas dessas duas palavras, a maioria dos autores aqui abordados acreditam que tal distinção não ecoa diferenças na linguagem estética destas figuras (Burnier, 2009; Camargo, 2012; Dorneles, 2003; Oliveira, 2008). Isto é, muda-se a palavra, mas mantém-se a essência do trabalho. Atualmente, como resultado da globalização, a palavra clown tem sido reconhecida mundialmente e já integra o vocábulo de outros idiomas, como o francês. No português, ambas as designações são utilizadas, sendo que "clown" costuma se referir mais claramente a um empreendimento artístico e profissional, enquanto "palhaço" pode ter conotações pejorativas (Dorneles, 2003). Neste trabalho não faremos distinção na nomenclatura: tanto "palhaço" quanto “clown" serão palavras utilizadas quando oportunas.

O ofício do clown ou palhaço, como hoje o conhecemos, é formado por um conjunto de bagagens e segmentos das mais diversas e contraditórias origens (Dario Fo, 2004). De acordo com Van Blerkom (1994), muitos estudos traçam as origens deste palhaço às 
performances xamanísticas e ritos de passagem dos povos primitivos. Neste sentido, Koller e Gryski (2007) afirmam que os palhaços aparecem em muitos povos das primeiras nações funcionando de modos similares aos santos, profetas e artistas de hoje. Para os povos da tribo canadense Dakota, os clowns são considerados os xamãs mais poderosos, ao passo que os povos norte-americanos da tribo Hopi possuem figuras sagradas de palhaços que atuariam na comunidade como bobos, padres e xamãs (Koller \& Gryski, 2007; Van Blerkom, 1994). Segundo Langer (1956), nas religiões primitivas, os clowns pertenciam aos cultos que celebravam a fertilidade e o crescimento - cultos estes que, na Grécia, eram dirigidos ao deus Comus, de onde teria se originado a palavra "comédia".

Desta forma, foi somente com o advento do cristianismo que os palhaços começaram a ocupar outro lugar dentro das crenças e ritos religiosos. Segundo Langer (1956), as associações da carne com o diabo e dos desejos com o pecado transformaram a figura do palhaço - profundamente ligada à nossa humanidade e impulsos primitivos - em um personagem obsceno e diabólico. Além disso, o clown, que sempre foi uma figura de subversão inteligente (Langer, 1956; Van Blerkom, 1995), passa a ter um outro espaço social na medida em que se desenvolvem e se enrijecem os limites da moralidade impostos pela Igreja (Dorneles, 2003). Na Idade Média, o ofício desses profissionais passa a ser considerado perigosamente provocativo, de modo que só lhes restam dois lugares: de um lado, a rua e as troças populares - onde eram constantemente perseguidos pelos poderes regulatórios da Igreja; e de outro, as disputadas vagas nos palácios e reinos - seja enquanto companhia de entretenimento, seja na figura singular que hoje conhecemos como "boboda-corte".

O bobo-da-corte, em particular, é considerado por muitos autores como o ancestral mais direto do palhaço atual (Dorneles, 2003; Matraca et al., 2011; Neves, 1974). Neste sentido, ainda que nosso imaginário remeta ao bobo europeu, faz-se importante ressaltar 
que estes tipos também fizeram parte das cortes astecas, russas, chinesas, africanas e egípcias (Dorneles, 2003).

A figura do bobo possui particularidades muito importantes com relação às demais manifestações cômicas. Segundo Burnier (2009), "bobos não eram atores que desempenhavam seu papel no palco; ao contrário, continuavam sendo bufões e bobos em todas as circunstâncias da vida. Encarnavam uma forma especial de vida, simultaneamente real e irreal, fronteiriça entre a arte e a vida" (p. 207).

Esse aspecto fronteiriço se manifestava também em outras dimensões de sua existência: o bobo encarnava certa loucura, mas suas pontuações tinham grande lucidez; ele vivia na Corte, mas não era considerado membro dela; ele não tinha estirpes, mas vivia em palácios; deveria ser crítico e bajulador, grotesco, mas atrativo. Enquanto uma figura subversiva em um contexto institucional, seu trabalho era permitir o contato com o sério a partir do riso. Desta forma, seu ofício era a encarnação de paradoxos (Matraca et al., 2011; Neves, 1974).

Esta existência no limiar das fronteiras que integram as interações humanas, por sua vez, constituiu-se como o maior trunfo e a maior agrura deste ser: se por um lado seu status de louco e sua comicidade lhe permitiam falar verdades; por outro, essa condição limítrofe lhe exigia muita sensibilidade para captar os limites (sempre transitórios) do momento presente. Muitos bobos foram condenados e decapitados no exercício da profissão por ultrapassarem essa tênue fronteira (Dorneles, 2003; Matraca et al., 2011).

Neste sentido, Dorneles (2003) observa que os bobos precisavam ser muito hábeis em lidar com a psicologia humana: "afinal, mexer com Instituições sem parecer leviano ou provocar ódio é uma arte que oscila nos limites da própria psicologia daquele que dela se utiliza" (p. 26). Como veremos mais adiante, esta sensibilidade também é uma 
característica importante no trabalho do atual palhaço e implica qualidades relacionais específicas a serem desenvolvidas - como escuta e aceitação.

Após a Idade Média, entre os séculos XV e XVI, como resultado da convivência entre palhaços, mímicos e fabuladores, surge na Itália a Commedia Dell'Arte, uma comédia de máscaras cujas atuações cômicas eram improvisadas a partir de um roteiro aberto, o canovaccio (Burnier, 2009; Dario Fo, 2004). Segundo Burnier (2009), esta arte se diferencia da arte da palhaçaria por envolver máscaras com tipos fixos - isto é, "personagens" a serem interpretados - ao passo que os palhaços, como veremos, emergem da própria personalidade daqueles que o encarnam (Lecoq, 2010). Contudo, ambas as artes compartilham características essenciais, como, por exemplo, a base no improviso e o enfoque cômico nos fracassos e ingenuidades humanas. Neste sentido, Dario Fo (2004) ressalta que a Commedia Dell'Arte não só surgiu do palhaço, como contribuiu para o desenvolvimento desta figura até a forma como é conhecida atualmente.

Por fim, a figura do clown como hoje a conhecemos tem suas origens no Circo. Segundo Burnier (2009), a criação do circo moderno se deu no século XVIII por Philip Astley, ex-sargento auxiliar da cavalaria inglesa. Ele costumava reunir cavaleiros que executavam exímios números a cavalo para realizar apresentações em formato de Arena o que mais tarde daria lugar ao picadeiro circular que ainda caracteriza muitos circos. Naquela época, alguns cavaleiros realizavam números como "recruta da cavalaria" e "grotescos a cavalo" em que simulavam simplórios camponeses que, de modo inesperado, realizavam proezas junto aos cavalos. Esses números eram utilizados como forma de divertir a plateia e aliviar a tensão entre um número e outro de maior periculosidade (Camargo, 2012). Neste contexto, o palhaço ganhou seu nariz vermelho e adquiriu seu caráter mais lúdico e de entretenimento - o que viria a mesclar-se com seu caráter provocador e subversivo, viabilizando um clown mais lírico. 
Atualmente, esta figura do palhaço é bastante difundida: encontramo-lo não só no circo, mas nas ruas, teatros, cinemas, escolas, festas e até mesmo em hospitais. Contudo, tal difusão tem causado também uma diluição do conhecimento sobre seu trabalho e alguns equívocos com relação à sua arte. Neste sentido, autores como Lecoq (1987) e Dario Fo (2004) afirmam que tem sido cada vez mais comum observar uma visão reducionista do palhaço, limitando-o a um certo tipo de caracterização - vestimenta, voz e maquiagem - e, no mais das vezes, a um exibicionismo - uma "simulação" de inocência e fracasso numa tentativa forçada de fazer o outro rir. Tais aparições são muito comuns nas ruas, nos semáforos e nas festas infantis. Para a maioria dos clowns profissionais, este tipo de trabalho é equivocado e não corresponde à arte da palhaçaria. Nas palavras de Dario Fo (2004),

certos atores vestem uma bolinha vermelha no nariz, calçam sapatos descomunais e guincham com voz de cabeça, e acreditam estar representando o papel de um autêntico clown. Trata-se de uma patética ingenuidade. O resultado é sempre enjoativo e incômodo. É preciso convencer-se de que alguém só se torna clown em consequência de um grande trabalho constante, disciplinado e exaustivo (p. 304).

Para Lecoq (1987; 2010), o palhaço possui uma profunda dimensão psicológica, correspondendo a um modo de expressão perante a vida a ser trabalhado através de uma intensa pedagogia dramática - meio pelo qual o sujeito desenvolveria o seu clown pessoal.

Durante muitos séculos, tal pedagogia foi realizada por meio da convivência entre palhaços iniciantes e aqueles mais experientes. No circo, em muitos casos, o conhecimento ainda é passado entre gerações de palhaços - os palhaços mais experientes procuram criar 
situações cujas experiências conduzam o jovem aspirante a encontrar e desenvolver sua lógica de clown (Burnier, 2009).

Nos últimos dois séculos, contudo, especialmente na Inglaterra e na França, cursos de profissionalizações circenses também começaram a existir (Camargo, 2012). Com isto, formações profissionais na arte da palhaçaria foram tomando forma - de modo a sistematizar as visões que os palhaços circenses possuíam sobre esta arte, e condensar em exercícios pedagógicos suas experiências (Burnier, 2009). A escola de Jaques Lecoq, a de Philipe Gaulier e a escola Le Samovar são alguns exemplos das instituições que surgiram na França e que oferecem até hoje cursos de formação (Camargo, 2012). Atualmente, é possível encontrar em todos os cantos do mundo cursos, oficinas, workshops, estágios e residências em diversas linhas de trabalho com a palhaçaria (Camargo 2012; Dorneles, 2003).

Outra novidade da palhaçaria contemporânea é o palhaço terapêutico. Como vimos anteriormente, a relação entre o clown e as artes da cura remontam ao xamanismo e às sociedades primitivas. Além disso, o clown também aparece nos primórdios da medicina moderna: segundo Koller e Gryski (2007), o hospital de Hipócrates mantinha trupes de jogadores e palhaços no pátio da instituição, uma vez que os médicos acreditavam que o estado de espírito do paciente influenciava em sua cura. Contudo, apenas recentemente uma atenção maior tem sido direcionada para as especificidades do trabalho do palhaço no contexto das unidades modernas de cuidado, bem como para a integração de propósitos terapêuticos em sua presença. Neste sentido, Koller e Gryski (2007) defendem uma formação diferenciada para este tipo de palhaço e falam dos efeitos danosos que podem advir da presença de palhaços inexperientes neste contexto. Deste modo, atualmente, existem preparos especializados oferecidos para aqueles que desejam trabalhar em hospitais, bem como vários grupos de clowns profissionais que ocupam sistematicamente 
os espaços hospitalares, como é o caso do Le Rire Médicin (Médicos do Riso) na França e do Clown Care Units (Unidades de Cuidado com Palhaços) do Big Apple Circus, em Nova York, bem como dos Doutores da Alegria, Doutores Música e Riso e do Projeto Risadinha, no Brasil.

Como podemos observar, o palhaço faz parte da história da humanidade. Independente da cultura, do tempo e do lugar, essa figura tem emergido e encontrado espaços para sua arte. Neste sentido, Towsen (citado por Dorneles, 2003) afirma que o clown "tem sido perpetuamente redescoberto pelas sociedades porque - como bobo da corte ou aplicador de truques - ele encontra necessidades humanas que o impulsionam" (p. $18)$.

De acordo com o que discutimos no capítulo 1, a vivência estética diz respeito à experiência de nos envolvermos em uma atividade de corpo e mente, tomando parte imaginativa na mesma, a fim de levarmos à completude necessidades profundas do nosso ser (Dewey, 2005). Deste modo, podemos compreender que a arte da palhaçaria tem se reinventado e se feito presente ao longo dos tempos por consistir em manifestações que levam a cabo profundas necessidades humanas. Neste sentido, Towsen (citado por Dorneles, 2003) reitera que o palhaço representa uma visão de mundo muito valorizada pela humanidade. Mas qual seria esta visão? Em que os palhaços se diferenciam dos demais profissionais do humor? Quais são as qualidades e especificidades que caracterizam sua figura e distinguem sua formação? As seções seguintes visam abordar estas questões.

\subsection{A figura do palhaço e as particularidades de seu trabalho.}

Como vimos na seção anterior, diferentes manifestações clownescas e linhas de trabalho com o clown tomaram forma ao longo da história da humanidade. Do mesmo 
modo, na palhaçaria ocidental contemporânea também é possível observarmos diferentes vertentes de trabalho e formas de compreensão do palhaço.

Neste sentido, atualmente, existem linhas de trabalho na palhaçaria voltadas tanto para os procedimentos cômicos, quanto para os estados cômicos (Burnier, 2009; Lecoq, 2010; Oliveira, 2008). As linhas de trabalho que enfatizam os procedimentos cômicos, segundo Burnier (2009), dão mais valor às gags e números cênicos, isto é, a determinadas fórmulas que, quando bem executadas, podem gerar o riso. Já as linhas de trabalho que enfocam os estados cômicos dão mais valor à descoberta e ao desenvolvimento da lógica particular do clown, isto é, voltam seu treinamento para o aprendizado de determinados estados que permitam uma forma clownesca de se relacionar com o mundo, tendo como consequência o riso.

Por conseguinte, ainda que a divisão acima não seja rígida e as formações em palhaçaria tendam a permear ambas as vertentes, faz-se importante destacar que as próximas seções deste capítulo irão se concentrar nesta segunda perspectiva: discutindo sobre as qualidades e processos que constituem o estado cômico do palhaço. Dentro deste escopo, voltaremos nosso olhar para a abordagem mais lírica desta figura, típica de algumas escolas de palhaço francesas (Camargo, 2012).

\subsubsection{O palhaço: qualidades e processos}

Nesta seção discutiremos a essência cômica do palhaço e os principais processos e qualidades que constituem a sua figura. A fim de tornar esta exploração mais didática, dividimos em diferentes tópicos as características que compõem seu ofício, sendo elas:

1. Autenticidade e ingenuidade

2. Extramoralidade (amoralidade)

3. Awareness (escuta) 


\section{Empatia}

5. Habilidade de "jogar com"

6. A estética cômica e o ridículo pessoal

Entretanto, faz-se importante destacar que, na prática, tais aspectos encontram-se profundamente relacionados, de modo que o desenvolvimento dos processos e qualidades que permeiam uma determinada característica também contribuem para o desenvolvimento das demais, como veremos a seguir.

\subsubsection{Autenticidade e ingenuidade}

Diferentemente do que muitos possam pensar, o palhaço não é um personagem. Pelo contrário, o clown deve ser a pessoa em seu estado mais autêntico, pois é da honestidade inesperada de suas ações que surge o humor.

Segundo autores como Burnier (2009) e Assis (2010), o desafio do trabalho com palhaços é justamente esta autenticidade: não interpretar, representar, ou fazer cena, mas simplesmente ser você mesmo, colocando-se disponível para afetar e ser afetado pelo mundo que o cerca. Como afirma Dimitri (citado por Oliveira, 2008): “Eu não represento um papel: estou nu; o clown é o mais nu de todos os artistas porque põe em jogo a si mesmo, sem poder trapacear. Para não decepcionar o público ele tem o dever de ser autêntico" (p. 17).

Neste sentido, autores como Dorneles (2003), Oliveira (2008) e Camargo (2012) discutem sobre a disponibilidade que o palhaço deve ter para reconhecer e ser sincero com os estados, emoções e pensamentos espontâneos que emergem das suas relações com o mundo. Nas palavras de Oliveira (2008), 
se a situação que ele [o palhaço] se encontra provocar nele tranquilidade, assim ele deve agir, se provocar timidez ou angústia, ele deve respeitar esses sentimentos e agir a partir deles, aceitando-os, rejeitando-os, criticando, ou transformando, mas jamais ignorando seus sentimentos e emoções despertados durante a cena (p. 88).

É desta honestidade que emerge o humor do palhaço. Os primeiros estados, emoções e pensamentos que tomam conta de nosso corpo, antes que tenhamos tempo de fazer uma reflexão consciente da situação, não obedecem às lógicas socialmente convencionadas, mas a um "raciocínio vivencial” próprio. Neste sentido, as lógicas que acompanham estas primeiras reações, ainda que façam sentido, nem sempre correspondem a atitudes socialmente esperadas (Assis, 2010).

Comumente nós ignoramos estas primeiras reações e suas lógicas primárias, pois rapidamente passamos ao raciocínio convencional. Contudo, o trabalho do palhaço é o de reconhecimento e expressão destas lógicas, pois elas propõem uma saída inesperada à forma como usualmente nos colocamos diante do mundo e das situações, gerando humor.

Em outras palavras, ao reconhecer e exteriorizar um outro sistema de referências em seu relacionamento com o mundo - proveniente do seu corpo, em suas próprias experiências e lógicas -, o palhaço apresenta uma maneira única e cômica de vivenciar e lidar com as situações. É neste sentido que Oliveira (2008) afirma: “o palhaço, quando levado a confrontar-se com a lógica vigente, cria a sua própria lógica” (p. 16).

$\mathrm{Na}$ linguagem da palhaçaria, portanto, a honestidade é essencial, sobretudo consigo mesmo: a emergência do humor no clown depende diretamente do quanto suas atitudes inesperadas forem “justas” (Berky \& Barbre, 2000; Lecoq, 2010). As atitudes “justas” são aquelas que, por mais absurdas que sejam, partem de uma lógica que realmente é sentida e vivenciada pela pessoa, fazendo sentido em algum nível, de modo que levam os demais à 
identificação e ao riso. Em contrapartida, dificilmente o sujeito ri das atitudes "não justas": quando percebe que o palhaço está negando a situação presente e "fingindo" pensar ou sentir-se de uma determinada forma para gerar o riso.

"Os clowns sempre dizem a verdade" (Castro, 1997, p. 7). Neste sentido, diversos autores afirmam que o palhaço é como uma criança: espontânea, e vivendo sob uma lógica própria que muitas vezes surpreende e faz rir os adultos (Camargo, 2012; Dorneles, 2003; Lecoq, 2010). Como a criança, ele se aproxima das coisas sem os costumeiros pressupostos sobre o que pode ou não sair daquela relação, surpreendendo a todos com as saídas lógicas que encontra para solucionar as situações (Dorneles, 2003).

Nesta perspectiva, muitos autores consideram o palhaço como um ser ingênuo (Camargo, 2012; Dorneles, 2003; Lecoq, 2010) - o que não significa dizer que ele seja tolo, pois é um ser profundamente esperto em sua ingenuidade, e inteligente em sua própria lógica. O clown é ingênuo porque possui um estado de "não saber", um estado de “por que não?”, típico das crianças.

Não obstante, autores como Camargo (2012) observam que esta ingenuidade coloca um problema ao sujeito que deseja trabalhar com o clown: se, por um lado, a honestidade é essencial para a palhaçaria, por outro, o sujeito cômico já é uma pessoa imbuída de valores e regras sociais, de modo que não é mais ingênuo como uma criança. Assim sendo, como o palhaço pode ser honestamente ingênuo? Como pode despir-se das máscaras e convenções sociais e colocar-se de forma autêntica e disponível na relação, respeitando suas reações primárias e seus sentidos imediatos?

Segundo Camargo (2012), a resposta está na forma como compreendemos e abordamos a ingenuidade: ao invés de pensarmos na construção do "ingênuo" em si como se este fosse um personagem com comportamentos e formas de pensar prédeterminadas -, devemos pensar na construção de caminhos que levem à ingenuidade, 
compreendendo-a como um estado. Neste sentido, Dorneles (2003) afirma que os caminhos para um estado de ingenuidade e disponibilidade permeiam o desenvolvimento de uma extramoralidade (ou amoralidade), isto é, um estado que nos permite despir das normas comuns sem ignorá-las. É sobre este estado extramoral (ou amoral) que falaremos a seguir.

\subsubsection{Extramoralidade (amoralidade)}

O palhaço é um ser amoral (Langer, 1956; Oliveira, 2008). Isto é, ele é um ser livre de valores e julgamentos sociais, que não possui compromisso com qualquer estilo de vida, seja ele ideal ou institucional (Burnier, 2009; Camargo, 2012). Seu compromisso é com a realidade na forma como esta chega para ele no momento presente, de modo que suas regras são criadas por ele mesmo a cada instante, a partir da sua própria lógica de compreensão do mundo (Camargo, 2012).

Isto não significa, contudo, que o palhaço seja um ser imoral, ou que simplesmente ignore a moral vigente. Segundo Dorneles (2003), ele apenas aprende a lidar com a moralidade de um modo diferente, no desenvolvimento de uma postura que ela chama de "extramoral". Para essa autora, a "moralidade" consiste em uma atitude de justificativa e

validação da moral como se ela tivesse um valor em si mesma, ao passo que a "extramoralidade" reconhece que este valor é fabricado: "dá-se conta da ilusão, o que não significa que a partir de então vá abolir toda moral. Essa moral apenas não vai ser vista com ingenuidade” (p. 59), ela será “dessacralizada”, como a autora coloca.

Neste sentido, o palhaço é crítico e reflexivo, porém não realiza condenações valorativas. Ele também não afronta de modo apelativo e exibicionista esta moralidade, pois tal atitude seria igualmente moralista - uma vez que envolve a tentativa de impor um determinado julgamento de valor como se ele fosse superior e correspondesse à real 
"verdade". Para o clown, não há fatos eternos nem verdades absolutas: ele reconhece a moral vigente e brinca com ela dentro dos limites que identifica serem possíveis na relação.

Como vimos nos capítulos anteriores, esta postura amoral é fundamental para a produção do humor, pois somente ao reconhecermos as crenças e valores pelo que realmente são - crenças e valores - é que podemos estabelecer uma relação mais honesta com a realidade, subvertendo as deduções lógicas que se seguem às normas instituídas em favor de outras deduções possíveis. O palhaço leva isso ao extremo, resultando no estado de ingenuidade.

O maior contato com este estado extramoral (ou amoral), por sua vez, envolve o desenvolvimento de importantes processos pessoais e qualidades relacionais.

De acordo com Dorneles (2003), a pessoa se apega à moral quando se sente fragilizada e ameaçada em sua fragilidade:

Quanto menos meu corpo pode processar os desequilíbrios que provém das relações com o outro, menos posso suportar esta alteridade e mais preciso criar barreiras que me protejam daquilo que já não se pode suportar e dar conta. Contudo, todo esse processo está fincado nas origens da própria noção de moralidade, que não poderemos aprofundar neste trabalho, mas que cria um homem regular, previsível, com certos esquemas de pensamento (p. 56).

Desta forma, a relação com a moralidade é um ciclo: a insegurança com nossa fragilidade nos leva a confiarmos mais na moralidade do que em nós mesmos, enquanto ela, por sua vez, é raiz de nossos julgamentos e inseguranças (Rutherford, 1994).

Portanto, Dorneles (2003) discute que o processo de se tornar clown implica no desenvolvimento de uma postura de aceitação, inclusive de nossos erros, de nossos 
defeitos, das marcas que carregamos conosco e até mesmo das rejeições que sofremos. É apenas reconhecendo profundamente nossas imperfeições que nos libertaremos de suas amarras, uma vez que a negação impede nossa presença integral e a possibilidade ativa de lidar com as questões. Isto também é verdade para o relacionamento com o outro. Segundo Koller e Gryski (2007), o palhaço deve se dar conta de que em certas ocasiões, apesar de seus melhores esforços e por quaisquer razões, não é possível estabelecer uma responsividade com o outro, caso em que ele deve reconhecer e aceitar seu fracasso e se retirar.

Neste sentido, ser clown envolve um trabalho constante com a nossa capacidade de lidar com a vulnerabilidade, pois implica um processo de arriamento de nossas defesas para que possamos estabelecer um contato genuíno com os elementos sensíveis e interiores de nosso ser (Burnier, 2009). Tal processo, por sua vez, exige não só o desenvolvimento de uma confiança em nós mesmos e uma coragem para nos vulnerabilizarmos, como, principalmente, um constante trabalho com o nosso ego, sua necessidade de controle e seus mecanismos de defesa (Dorneles, 2003; Hycner, 1995) - o qual será mais bem abordado na seção sobre o treinamento.

Este estado de aceitação e o consequente desnudamento de uma postura moralista, por sua vez, permitem ao sujeito colocar-se mais integralmente em suas relações, forjando um contato com outras possibilidades de ser e de fazer, antes inacessíveis. Em outras palavras, o sujeito desenvolve uma atitude expectante e de "reverência pelo que é", rompendo com os preconceitos do que é normal e do que é imperfeito para colocar-se de forma mais honesta nas relações, explorando abertamente o potencial das coisas que estão ao seu redor. Segundo Berky e Barbre (2000), o clown explora e utiliza o potencial de todas as coisas, inclusive dos erros e das imperfeições, uma vez que, para ele, estes defeitos são apenas realidades - sem julgamento de valor, ele os utiliza em sua própria 
lógica e a seu próprio favor. Neste sentido, esses autores (Berky \& Barbre, 2000) afirmam que o palhaço nos acorda para uma "awareness vital", uma postura viva e presente, procurando explorar o potencial de todas as coisas. É sobre esta awareness que falaremos a seguir.

\subsubsection{Awareness (escuta)}

O palhaço se relaciona com o aqui-e-agora. Por se desnudar das regras e julgamentos sociais, o clown não sabe o que vai acontecer assim que se inicia a relação, o que lhe permite não só uma disponibilidade e abertura, mas uma prontidão para perceber, reagir e utilizar o que quer que chegue até ele.

Nas palavras de Assis (2010),

para o palhaço não se sabe o que acontece quando diante de um picadeiro. Essa atitude, faz com que o seu ângulo de percepção e visão possa estar amplificado, de certo modo que se um avião passar, isso lhe é fiel à sua audição, causando-lhe um estado espontâneo de reação àquilo (p. 44).

Neste sentido, Burnier (2009) afirma que ao invés de atuar excessivamente sobre as pessoas e objetos, o trabalho do palhaço implica colocar-se disponível para "ouvir" os mesmos, isto é, reconhecer e aceitar as dinâmicas que estes propõem e a forma como elas o afetam. Do mesmo modo, Oliveira (2008) afirma que o trabalho do clown envolve o desenvolvimento da capacidade de escuta por parte do sujeito, a fim de que possa aprender a estabelecer conexões reais consigo mesmo, com quem contracena e com a plateia. Destarte, o que os autores da palhaçaria compreendem como uma "escuta" se aproxima muito ao que discutimos até aqui como um estado de awareness, isto é, um movimento de voltarmos nossos sistemas sensório-motor, emocional, cognitivo e energético para a esfera 
do "entre", possibilitando-nos estar atento simultaneamente à nossa própria existência, à experiência do outro, e ao desenvolvimento continuamente mutante da relação entre ambos.

Nesta direção, Dorneles (2003) ressalta que ser palhaço não envolve apenas expressar o que vier à mente "liberando as emoções": o clown precisa se fazer presente e sentir o que se passa na relação, percebendo, inclusive, se está agradando ou incomodando o outro, se o outro aceitou ou não jogar com ele, quais são os limites que este outro sinaliza para a brincadeira, e como ele próprio se sente com relação a tudo isso. O palhaço deve estar atento e pronto para reconhecer qualquer coisa que lhe aconteça, inclusive seu fracasso.

Este estado de awareness é ainda mais fundamental diante de seu caráter subversivo: o clown precisa estar em contato intenso e honesto consigo, com o outro e com o ambiente, a fim de que sua lógica inesperada emerja de uma vivência da relação - fazendo sentido não somente para ele, mas para os demais envolvidos. Ademais, esta escuta é também importante para que o clown reconheça e admita quando não houver conexão com o outro e sua lógica não for compartilhada.

Nas palavras de Koller e Gryski (2007), “a máscara do clown requer que nós nos desmascaremos, que nós deixemos todas as nossas outras máscaras e aumentemos nossa sensibilidade aos outros” (p. 20). Neste sentido, a presença disponível da escuta se constitui como um dos principais pilares do treinamento em palhaçaria.

\subsubsection{Empatia}

Enquanto um aprofundamento da escuta é característica dos trabalhos de palhaço em geral, a empatia é uma qualidade do palhaço mais lírico e aparece mais frequentemente nos treinamentos do clown terapêutico. 
O palhaço empático é aquele que se coloca disponível ao encontro e aprendizado com aqueles com os quais entra em contato, desenvolvendo um vínculo autêntico e genuíno com os mesmos. Diferentemente das outras figuras de palhaço - que muitas vezes trabalham contra o outro, lançando mão da escuta a seu favor, inclusive para constranger os demais -, esta vertente a que nos referimos trabalha com a construção de uma cumplicidade com o outro (Castro, 1997), reconhecendo sua alteridade mesmo nos momentos de crítica.

Neste sentido, Bob Berky (Berky \& Barbre, 2000) relata sua experiência como palhaço de maneira a retratar o que seria empatia no trabalho de palhaçaria:

é essencial que ao invés de entrar no palco com um conjunto de respostas, eu descubra onde a plateia está. Tome o exemplo de um antropólogo. Um bom antropólogo é aquele que entra em um lugar e diz "quem são essas pessoas" e "do que eles se tratam" - não "quem eu sou e o que estou trazendo" como o principal. (...) Eu tenho que descobrir onde os outros estão, e ir lá, e indo para onde eles estão, eu posso dizer “eu sou um de vocês, quer ir comigo para o palco?”. Eu não posso dizer “Ei, eu estou aqui em cima. Quer vir aqui em cima?”, porque eles dirão "Eu não sei como escalar tal montanha". E eles não me viram escalar uma porque eu [já] estou lá em cima. Então, ao invés disso, você desce e então vocês sobem juntos. Na peça de participação da plateia, não há nada que eu faça um indivíduo fazer que eu não faça primeiro (p. 242).

Para Berky, tal atitude pode ser resumida como um "estar com", que se encontra no coração da ressonância empática que podemos desenvolver com o outro. Neste sentido, Koller e Gryski (2007) enfatizam a importância do aprendizado de uma sensibilidade para lidar com o outro no treinamento de palhaço, ao passo que Camargo (2012) ressalta a 
qualidade humanista que constitui esta linha da palhaçaria. O palhaço, nesta vertente de trabalho, é um ser que se importa e que, paradoxalmente, leva muito a sério as trocas que estabelece com o mundo (Burnier, 2009).

Escuta e empatia, por sua vez, estão profundamente ligadas a uma outra qualidade fundamental que o palhaço deve desenvolver: a capacidade de "jogar com".

\subsubsection{Habilidade de "jogar com"}

O palhaço não representa diante de um público: joga com ele. De acordo com o que vimos anteriormente, o outro é parte fundamental da construção do trabalho do palhaço. Como Burnier (2009) observa, o palhaço se alimenta diretamente dos estímulos que vem dos seus espectadores "interagindo com eles numa dinâmica de ação e reação" (p. 219), de modo que Dorneles (2003) aponta que quando o clown entra em cena, tem o seu jogo influenciado por todos aqueles que estejam presentes.

Esta qualidade de jogo, por sua vez, é de caráter constituinte no palhaço: como vimos no capítulo 1, aceitar o convite à brincadeira e entrar em um set lúdico é fundamental para que o sujeito produza a saída lógica criativa que constitui o humor. Nesta direção, é fundamental que o palhaço aprenda a brincar e a construir um jogo junto com a plateia, a fim de que ambos compartilhem deste universo lúdico de lógicas incomuns.

Nas palavras de Burnier (2009), “o clown é como uma criança que, quando brinca, acredita integralmente em sua brincadeira (...). Depois da brincadeira, ela sabe que aquilo foi tudo um jogo" (p. 217). Nós complementamos: também a plateia deve brincar com o clown, passando pelo mesmo processo - sendo que cabe ao clown realizar esse convite.

Portanto, a arte do palhaço é a arte do jogo com o outro. Neste sentido, alguns autores afirmam que o palhaço só existe na relação (Dorneles, 2003; Koller \& Gryski, 
2007; Oliveira, 2008), e isso é verdade, mas é mais do que isso: o palhaço só existe em uma relação de jogo.

Esta qualidade lúdica do trabalho do palhaço, por sua vez, implica outra habilidade fundamental: a capacidade de improviso. Segundo Camargo (2012), os jogos implicam certas estruturas de proposição e, portanto, em intencionalidades; contudo, tais estruturas não são rígidas e uma das diversões do jogo consiste justamente na forma como ele vai se desenrolar na relação aqui-e-agora, até chegar ao seu fim. Desta forma, mesmo quando consolidado em uma estrutura fechada de espetáculo, o trabalho do palhaço envolve necessariamente as construções que ocorrem através da relação que ele desenvolve com os demais no momento presente, de modo que deve colocar-se disponível, inclusive, para modificar sua estrutura de súbito, quando necessário.

Adicionalmente, o jogo do palhaço envolve a ingenuidade e a amoralidade - isto é, conta com a subversão da lógica vigente em função de uma lógica mais literal e espontânea que emerge da relação - e, neste sentido, implica ainda mais a lida com o fortuito e incalculável. Destarte, é possível afirmar que no treinamento de palhaço a improvisação não é apenas um meio para um fim - isto é, uma técnica para desenvolver uma habilidade - mas sim um fim em si mesma: ela corresponde a uma qualidade característica da existência do clown (Langer, 1956), está profundamente relacionada ao desenvolvimento de um senso de timing cômico e deve ser praticada em seu ofício.

Assim sendo, o sujeito que deseja trabalhar com o clown precisa não só aprender a arte do improviso, como a arte do improviso na linguagem da palhaçaria - ou seja, envolvendo as especificidades de seu jogo (Camargo, 2012). Desta forma, o último tópico desta seção visa aprofundar em algumas outras particularidades que envolvem o jogo do clown. 


\subsubsection{A estética cômica e o ridículo pessoal}

O palhaço é um ser ridículo: sua existência expõe de maneira cômica o ridículo que constitui a nossa natureza humana (Camargo, 2012). Por ridículo, aqui, entendemos tudo aquilo que fracassa com a norma, abrangendo dos erros e defeitos mais grotescos à uma falta de senso que torna o sujeito inapropriado. $\mathrm{O}$ palhaço, devido à sua ingenuidade $\mathrm{e}$ amoralidade, expõe de forma desnuda suas reações primárias, erros e fracassos e, desta forma, é um ser completamente inadequado.

Neste sentido, autores como Burnier (2009) e Lecoq (2010) ressaltam que a pesquisa do sujeito para desenvolver o seu estado clownesco envolve necessariamente a pesquisa de seu próprio ridículo. Burnier (2009) afirma que "descobrir o próprio clown significa confrontar-se com o próprio ridículo, tendo por base a ingenuidade" (p. 210), enquanto Lecoq (2010) complementa que "quanto menos se defender e tentar representar um personagem, mais o ator se deixará surpreender pelas suas próprias fraquezas" (p. 214).

Frequentemente, temos o receio de sermos autênticos e expormos nossa ingenuidade justamente por medo de sermos inadequados. Desta forma, a atitude ingênua desenvolvida pelo palhaço envolve admitirmos e acolhermos nosso ridículo (incluindo nossos defeitos) para que possamos desenvolver a liberdade de apenas "ser". Em outras palavras, a ingenuidade do clown e sua amoralidade constituem uma outra forma de relacionamento com a inadequação e o fracasso - forma esta marcada pela estética cômica.

Como vimos no capítulo 1 , a estética cômica remete a uma forma básica de se situar no mundo que

celebra a capacidade humana de suportar, dramatiza o fato de que não importa quantas vezes nós podemos ser derrubados ou ficar aquém, nós de alguma 
forma conseguimos nos levantar e seguir caminhando. (...) revela a inextinguível vitalidade do nosso próprio impulso de sobreviver (Corrigan, 1981, p. 8).

Neste sentido, de acordo com o que já discutimos, a experiência do humor implica algumas posturas primordiais do sujeito com relação ao mundo, como a senciência (a presença e atitude de viver pelo momento); o oportunismo inteligente frente às dificuldades; e a vitalidade inextinguível perante as lutas como mundo ${ }^{21}$.

Destarte, o clown é a estética cômica personificada: sua existência mimetiza as constantes aventuras e desventuras, o cair e levantar-se, o desajustar-se e ajustar-se que compõem a nossa trajetória humana, mostrando, por meio de saídas lógicas criativas, a capacidade do ser humano de se reinventar. Sua autenticidade, seu caráter de jogo e a necessidade de escuta no aqui-e-agora constituem uma atitude senciente; ao passo que sua lógica primária permite o oportunismo inteligente característico da experiência cômica.

Nesta perspectiva, Langer (1956) afirma que o palhaço é divertido e engraçado justamente porque, mesmo nos momentos de pesar e desânimo, sua energia permanece intacta, e cada fracasso se torna apenas uma oportunidade para um novo movimento fantástico.

Em outras palavras, o clown encarna uma forma caracteristicamente humorada de relacionamento com o nosso ridículo, podendo ter seu trabalho resumido nas palavras de Assis (2010): “O clown lida com o erro, declarando e assumindo o seu ridículo e é recompensado com o riso e a continuidade da vida" (p. 44).

Mas como podemos aprender a desenvolver os estados, qualidades e características destacados acima como constituintes desta comicidade? Como podemos encontrar um estado de amoralidade, acessar nossa lógica primária, e desenvolver uma outra atitude com relação ao nosso ridículo? As respostas a estas perguntas já foram e têm sido objeto de

\footnotetext{
${ }^{21}$ Para maiores esclarecimentos, vide quadro 3, apresentado no capítulo 1.
} 
estudo de vários pesquisadores e artistas, de modo que abrangê-la de maneira compreensiva poderia facilmente se constituir como o trabalho de uma vida.

Por conseguinte, a próxima seção deste capítulo visa apresentar apenas algumas das possibilidades de desenvolvimento desses processos e qualidades, a fim de favorecer a compreensão de como seu treinamento poderia ser utilizado como ferramenta no desenvolvimento do senso de humor do psicoterapeuta.

\subsection{A arte da palhaçaria: aprendizado e treinamento}

Como vimos nas seções anteriores, o palhaço não corresponde a um personagem (com uma estrutura fixa e rígida de personalidade), mas a uma determinada forma de vivenciar o mundo, isto é, um certo estado que pode ser acessado e desenvolvido por meio de diferentes experiências as quais permitam o alcance de seus processos e qualidades.

No treinamento de palhaço, cada mestre ou professor faz uso de diferentes técnicas para proporcionar tais experiências e, assim, viabilizar a descoberta desse estado clownesco por parte dos alunos. Esse estado, por sua vez, vai se desenvolver de maneira muito particular na experiência de cada um, uma vez que o palhaço implica um modo de expressão pessoal e autêntico diante da vida (Burnier, 2009). Neste sentido, Dorneles (2003) ressalta: “o clown não tem receita, é preciso experimentar e não se faz de imediato" (p. 53).

Esta seção do capítulo discute alguns dos processos que comumente constituem um treinamento de iniciação na arte da palhaçaria, a fim de elucidar como pode acontecer a descoberta deste clown pessoal e o primeiro desenvolvimento dos processos e qualidades que constituem o seu estado.

Para fins didáticos, dividimos estes processos em: a) exercícios de desnudamento; b) exercícios de awareness; c) exercícios de incitação a reações e lógicas primárias. Contudo, 
faz-se importante ressaltar que, assim como os diferentes processos e qualidades do clown se encontram profundamente relacionados, também seus diferentes processos de treinamento se implicam - isto é: mesmo os exercícios que possuem como foco principal um determinado processo, geralmente tangenciam e contribuem para o desenvolvimento dos demais.

Outro ponto importante é que os exercícios que constituem o treinamento do palhaço consistem majoritariamente em jogos - o que, por si só, já contribui para o maior contato com a natureza lúdica do universo cômico, bem como para o desenvolvimento de uma habilidade de "jogar com". Como veremos, alguns desses jogos são realizados em conjunto por todos os alunos, enquanto outros consistem em improvisos executados por uma parcela e assistido pelos demais. Ao final de um jogo é comum que o professor comente e, por vezes, dê abertura para que os colegas também o façam, dando um feedback sobre a proposta do exercício e seu cumprimento pelo aluno - pautado nas habilidades que o respectivo jogo exigia. Em outros casos, o feedback vem em forma de provocação no próprio momento do exercício, no qual o professor pode atuar como um "diretor" fazendo comentários instigantes enquanto as pessoas que jogam prosseguem o jogo. A seguir apresentaremos alguns destes jogos e os processos implicados em sua evolução.

a) Exercícios de desnudamento: correspondem a exercícios que criam situações para que os mecanismos de defesas mais comuns do sujeito sejam suspensos. Estes jogos necessitam de honestidade por parte do (s) participante (s) para que sejam bem executados, de modo que o jogador seja confrontado em sua a falta de autenticidade e em suas tentativas de se esconder atrás das máscaras que constrói para si.

Tais atividades criam uma situação paradoxal incomum, em que aquilo que o sujeito tem criado para ser bem-sucedido ao longo da vida (suas máscaras) é justamente 
o que leva ao seu fracasso no exercício - de modo que apenas desnudando-se e vivenciando a essência do seu ser (com suas fraquezas e ridículos) consegue se tornar bem-sucedido na tarefa: "aqui, se imagina a dificuldade para se fragilizar justamente no momento em que o que mais se quer é o reconhecimento de suas capacidades, é este o confronto exigido" (Dorneles, 2003, p. 51).

Portanto, essas atividades têm como objetivo principal provocar uma "quebra" das barreiras defensivas do sujeito e trabalhar sua relutância em admitir a si mesmo tal como se é - com seus ridículos, fraquezas, e até mesmo potenciais escondidos.

Neste sentido, tais jogos são delicados e exigem a sensibilidade do professor para conduzi-los de forma cômica, de modo que tal "quebra", ainda que difícil, permaneça em uma esfera lúdica e, se possível, seja direcionado a experiências humoradas. Nas palavras de Dorneles (2003),

o diretor deve ser muito sensível para que uma possível insegurança que resulte dessa exposição seja direcionada para o cômico, o engraçado de uma tentativa de afirmação convicta de algo em ruínas, e não o sentimento de fracasso pelo confronto com a falência da proteção auto-sustentada (p. 49).

Cabe aqui retomar brevemente o que foi discutido nos capítulos anteriores sobre a diferença entre a estética cômica e a trágica. A comicidade possui um sentido de superação das dificuldades pela vitalidade humana: ela remete ao oportunismo inteligente perante as adversidades, bem como à "transiência" dos processos e estados da natureza. Deste modo, na forma cômica de se situar no mundo não há condenações de caráter, fatos eternos, ou verdades absolutas. Tal se diferencia muito de uma condução trágica que se pauta nas fatalidades imputadas pelas dificuldades e no determinismo dos valores e normas vigentes. 
Neste sentido, é de fundamental importância que o diretor ou professor esteja imbuído de uma estética cômica para ajudar o aluno a lidar com as dificuldades e fracassos que apresenta, conduzindo-o a vivenciá-los de modo cômico.

Alguns exemplos de jogos deste caráter são:

a. "Faça-me/convença-me" "22: Este exercício acontece, muitas vezes, em "penalidade" aos jogadores perdedores de algum outro desafio. Nele, a pessoa é ordenada pelo professor a convencer os demais de algo ou provocar-lhes algum tipo de emoção. A pessoa pode, por exemplo, ser solicitada a fazer os demais rirem, ou chorarem; a convencer os outros de que é o melhor mágico do mundo (mesmo que não saiba fazer mágica), de que é a pessoa mais bonita, mais feia, mais gorda, ou mais leve do mundo, etc. Para executar esse exercício, é preciso que o sujeito acredite de verdade naquilo que propõe, e seja sincero em seu acreditar, ao invés de tentar forçar o outro a acreditar por ele. De tempos em tempos, o professor pode perguntar a cada um dos espectadores para que diga em voz alta se o jogador o "convence". Os espectadores devem responder "sim" ou "não", e o objetivo do exercício é que o jogador consiga que todos digam "sim". Este exercício pode durar bastante tempo, principalmente se a pessoa estiver tendo dificuldade, pois uma das finalidades é justamente o desenvolvimento de uma atitude de honestidade e de acreditar em si, deixando de se apoiar em suas máscaras e tentativas forçadas. Outra finalidade é justamente a de que a pessoa se depare com sua vulnerabilidade e seu fracasso e tenha a oportunidade de lidar com eles. Ao final, se a pessoa consegue convencer os demais, sua vitória é celebrada com grande alívio para a mesma; caso não, o professor instrui a mesma a sentir e perceber como é este sentimento de fracasso, de forma a mostrar para essa pessoa que ela pode sobreviver ao reconhecimento de seu próprio erro e dificuldade.

\footnotetext{
22 Exercício extraído de Oficina de Palhaçaria Iniciante com Denis Camargo, entre outubro e dezembro de 2013, em Brasília, no Teatro Mosaico.
} 
Todos os alunos passam por este processo, de forma que existe também a oportunidade de que a pessoa que já vivenciou o exercício perceba que os demais também possuem dificuldades, gerando um sentimento de compartilhamento. $\mathrm{O}$ professor deve estar atento para observar se os espectadores também estão sendo sinceros em seu julgamento ou se estão aceitando a performance do colega por compaixão. No segundo caso, o professor deve apontar o que está acontecendo e pedir a sinceridade desse espectador, perguntando-o, novamente, se realmente está se sentindo mobilizado. É interessante perceber que muitas vezes este exercício resulta em risadas por parte dos espectadores, pois as reações primeiras e as lógicas inesperadas que as pessoas começam a expor diante de sua vulnerabilidade e de suas tentativas frustradas provocam uma experiência cômica na plateia.

b. "Quem é mais interessante?" ${ }^{23}$ : neste jogo, duas pessoas ficam em lados opostos da sala - metade da plateia fica assistindo a um, enquanto a outra metade se volta para o outro. Ambos começam o exercício, cujo objetivo é conseguir para si o interesse do público. Vale tudo, menos pedir diretamente por esta atenção. Após um tempo, ao soar do sino (dado pelo professor), a plateia ganha mobilidade: a liberdade de poder se virar e assistir à performance do outro aluno, caso a pessoa a quem assiste não estiver interessante o suficiente - podendo também voltar a essa primeira pessoa, caso ela mude de estratégia e faça algo novamente que chame a atenção dos demais. Ganha quem primeiro conseguir que toda a plateia se vire em sua direção. Este exercício é bastante simbólico, uma vez que, por estarem de lados opostos, o perdedor do jogo acaba com toda a plateia de costas para ele. A competição se segue em duplas.

\footnotetext{
${ }^{23}$ Exercício extraído de Oficina de Palhaçaria ministrada pelo palhaço argentino Chacovachi, na $14^{\mathrm{a}}$ edição do FestClown, Brasília, maio de 2016.
} 
c. "Eu sou o chefe, eu mando" "24: Este exercício também implica uma postura não só de honestidade como também de acreditar em si - mesmo em face a sua própria inabilidade e incompetência. O jogo é composto de dois jogadores: um deles começa como o mestre. Este deve exigir que o outro faça algo - apresente uma habilidade, como "cante uma música em francês"; ou até mesmo mostre coragem para realizar algo difícil, como "lamba o chão". A pessoa que for o mestre deve iniciar suas ordens com a frase "Eu sou o chefe, eu mando". Caso a outra pessoa consiga executar o solicitado, ela se torna o mestre, do contrário, ela apanha do colega com o "tio frasquito" 25 . Não existe a possibilidade, segundo as regras do jogo, de “desistência", isto é, de não se esforçar para fazer o solicitado. A pessoa deve tentar cumprir as ordens mesmo que em um primeiro momento não acredite que consiga cumprir. Um dos objetivos é o de que os sujeitos se deparem com ordens as quais tenham dificuldade de cumprir e as superem, seja por coragem (caso seja algo que constranja ou cause nojo na pessoa), seja por uma saída lógica inteligente (caso não tenha condições de realizar a ordem pelos meios comuns). Outro objetivo é de que a pessoa lide com o fracasso e sua condenação, bem como a frustração "perder" o posto de mestre e de ser mandado pelo colega em quem antes estava mandando.

É a partir dos processos forjados por exercícios como estes que o sujeito começa a acessar e desenvolver maior domínio sob seu estado de amoralidade e a sua sensibilidade cômica para lidar com o ridículo, pois eles permitem, dentre outras coisas: i. o contato com a lógica primária; ii. o aprendizado da lida com a vulnerabilidade; iii. a aceitação do que foge ao controle; iv. o desenvolvimento de uma atitude de confiança em si e na vida.

\footnotetext{
24 Exercício extraído de Oficina de Palhaçaria Iniciante ofertada por Denis Camargo entre outubro e dezembro de 2013, em Brasília, no Teatro Mosaico.

${ }^{25}$ Objeto construído com jornal, cujo impacto no corpo, embora faça barulho, não machuca ou gera dor.
} 
i. O contato com a lógica primária: Segundo Burnier (2009), nestas situações de arriamento das defesas naturais, é comum o surgimento de uma série de gestos que "escapam" ao controle do sujeito, chamados pelos franceses de "gestos-emfuga". Estes correspondem às reações primeiras que o sujeito não consegue esconder e cuja lógica primária, como vimos na seção anterior, é característica do humor do clown.

Além disso, alguns exercícios colocam a pessoa em tais situações que exigem dela um oportunismo inteligente a fim de vencer, o que pode permitir a emergência de saídas lógicas inesperadas por parte do mesmo, as quais sejam cômicas para os demais. Neste sentido, as experiências desses exercícios possibilitam o início de uma compreensão corporificada dos caminhos vivenciais que levam ao riso.

ii. O aprendizado da lida com a vulnerabilidade: Como vimos na seção anterior, acessar o estado de amoralidade implica aprender a lidar com a vulnerabilidade. Tais exercícios, por meio da condução sensível do professor, levam os alunos a adentrar momentos de extrema vulnerabilidade e sobreviver a eles, mesmo no fracasso. Além disso, as falhas da "moral" vigente em dar suporte para os sujeitos nesses exercícios começam a gerar nos mesmos um sentido de que as normas e máscaras que construímos no nosso cotidiano são limitadas. Tal sentido, por sua vez, contribui diretamente para o processo de "desmistificação" e distanciamento da moral vigente - atitudes que, como vimos anteriormente, são fundamentais para a emergência de uma lógica cômica.

iii. O reconhecimento do que foge ao seu controle: segundo Dorneles (2003), exercícios deste caráter também levam o sujeito a encarar situações que fogem ao seu controle, aceitando a situação tal como ela é, e, assim, colocando-se 
aberto para explorar as possibilidades do momento presente. Tal atitude de "não saber" não só constitui a amoralidade como é fundamental para o "jogar com" e a emergência de um estado de ingenuidade.

iv. O desenvolvimento de uma atitude de confiança perante a vida: a maioria dos exercícios de palhaço envolve que o sujeito acredite em si mesmo e em suas proposições. Neste sentido, seus processos permitem que o sujeito desenvolva uma confiança em si mesmo a qual não esteja pautada no sucesso ou na negação do fracasso, mas na sua integridade e na convicção da capacidade humana de se reerguer perante as constantes lutas com o mundo. Como vimos nas seções anteriores, esta atitude é característica da estética cômica do palhaço.

Por fim, é preciso reconhecer que o contato do sujeito com a lógica do clown por meio de exercícios de desnudamento, ainda que em um contexto cômico e protegido, pode ser doloroso, uma vez que confronta a pessoa consigo mesma e expõe suas experiências e dificuldades mais bem escondidas. Contudo, segundo Burnier (2009), é daí que surge o caráter profundamente humano da figura do palhaço que, tendo passado por este processo, sensibiliza-se ao contato com o outro de uma forma que antes não era possível.

A seguir trataremos de outras formas de encontrar este caminho de sensibilização: os exercícios de awareness.

b) Exercícios de awareness: correspondem aos exercícios que criam situações para que os alunos se coloquem no aqui-e-agora de forma alerta e disponível. Tais atividades, para que sejam bem executadas, exigem que o sujeito volte a sua awareness para o momento presente, desenvolvendo um estado de escuta tanto com relação a si mesmo, quanto com relação aos demais presentes.

Alguns exemplos de exercícios deste caráter são: 
a. "Linha cruzada"26: A turma é colocada em círculo. Cada aluno diz seu nome em voz alta para que todos da roda o memorizem. A primeira "linha", portanto, corresponderá ao nome das pessoas. Coloca-se uma bola em jogo. A pessoa que começar com a bola deve falar em voz alta o próprio nome e, em seguida, o nome da pessoa para quem jogará a bola. Certificando-se de que esta pessoa ouviu o seu nome e está atenta, joga bola para ela. Esta, por sua vez, diz o seu próprio nome e, em seguida, o nome de outro jogador, jogando, então, a bola para o mesmo - e assim por diante. O jogo segue por algum tempo e o professor deve ir aumentado o desafio de modo que aqueles que cometerem qualquer desatenção - deixarem a bola cair, demorarem muito tempo para chamar um nome, ou esquecerem de falar o próprio nome - podem ser eliminados. A seguir todos retornam ao jogo e uma segunda "linha" é adicionada, representada por uma outra bola ou objeto, a qual corresponde a outra referência, como, por exemplo, nomes de frutas. Assim, cada pessoa deve falar o nome de uma fruta que irá representá-la. Uma pessoa da roda começa com a bola da "linha" inicial, pronunciando seu nome e depois o de um colega; enquanto outra pessoa inicia com o segundo objeto - pronunciando o nome da fruta que o representa e o nome da fruta de outro colega, lançando para ele esse objeto. Várias outras linhas podem ser adicionadas simultaneamente ao círculo, de modo que, ao final do treinamento, cada participante tenha, além de seu nome, uma fruta, um meio de transporte, uma cor e um animal, por exemplo, atrelados a si. Neste jogo, as pessoas devem estar em uma postura alerta e expectante não só para endereçar corretamente um ou mais objetos, mas para

\footnotetext{
${ }^{26}$ Exercício extraído da dissertação de mestrado de Denis Camargo: Oliveira, D. C. (2012). Formação em palhaço: Reflexões sobre metodologias de formação de novos palhaços. Dissertação de Mestrado, Instituto de Artes - Universidade de Brasília, Brasil.
} 
receberem os objetos: uma vez que possuem diversos "nomes" atrelados a si, correspondentes às diferentes "linhas" colocadas em jogo.

b. "Contação de histórias"27: A turma se divide em duas fileiras, uma em frente à outra. Uma fileira começa: o primeiro participante da direita ou esquerda deve iniciar uma história e, após contar um pouco dela, dar a deixa para que o colega do lado assuma sua continuidade. As três regras principais do jogo são: 1. A história deve seguir a sequência do alfabeto: a primeira pessoa inicia a história com uma palavra que comece com a letra "A" e cada pessoa deve continuar a história, iniciando sua primeira fala com a próxima letra do alfabeto; 2. A história seguinte não pode começar negando a história anterior, e, sim, deve ser congruente com ela, isto é, não pode haver uma atitude de negação como: "mas na verdade não foi bem assim que aconteceu", "só que tudo isso era mentira", etc.; 3. O participante seguinte não pode demorar muito para dar continuidade à história.

Quando alguém errar, passa-se a vez para o outro grupo. Ganha o grupo que for mais longe no alfabeto. Este é um exercício muito importante de escuta, pois a pessoa deve estar atenta não somente à sua posição no grupo (sua letra e seu processo de criação), mas também ao outro e à história que o outro está contando, uma vez que deve partir da mesma para a sua própria proposta. Neste sentido, é também um bom exercício para dar uma primeira noção do que é a postura de "jogar com", anteriormente discutida.

27 Exercício extraído de Oficina de Palhaçaria Iniciante ofertada por Denis Camargo entre outubro e dezembro de 2013, em Brasília, no Teatro Mosaico. 
c. "Aprendendo a respirar ${ }^{28} ":$ um dos alunos sai da sala enquanto os demais ficam como plateia. Ele deve entrar quando o professor autorizar e se colocar na frente de todos os presentes, sem tentar fazer nada. As instruções são as de que olhe nos olhos de cada um dos colegas e respire fluidamente até que seja dispensado pelo professor. Este último, por sua vez, pode fazer comentários ao longo do exercício para conduzir o aluno a realmente olhar para os presentes ou a respirar com maior fluidez e naturalidade. Quando dispensado, o aluno deve sair da sala. O grande desafio deste exercício é colocar-se num estado de abertura e disponibilidade, isto é, de "não saber" e "não fazer" nada, aprendendo a estar inteiramente presente e disponível na relação.

Quando ficamos nervosos, ou apreensivos, nossa tendência natural é de prendermos a respiração e desfocarmos o olhar, voltando nossa atenção para os nossos próprios pensamentos e preocupações - nos "desligando do mundo". Neste sentido, grande parte do trabalho com o palhaço consiste em exercitar a nossa respiração e o nosso olhar - aprender a respirar e a manter a conexão com os demais mesmo em estados de preocupação e nervosismo (Berky \& Barbre, $2000)^{29}$.

d. "Leitura das emoções" ${ }^{30}$ : é semelhante ao exercício do olhar e da respiração, mas dessa vez o aluno deve sair da sala enquanto os demais permanecem e escolhem emoções para serem expressas não verbalmente, como raiva, medo, ansiedade ou alegria. Estas pessoas não devem fazer nada a não ser assumir

\footnotetext{
${ }^{28}$ Exercício extraído de Oficina de Palhaçaria Iniciante ofertada por Denis Camargo entre outubro e dezembro de 2013, em Brasília, no Teatro Mosaico.

${ }^{29}$ Ver também fala de Avner, o Excêntrico, sobre o papel da respiração no treinamento do palhaço: https://www.youtube.com/watch?v=EBXrbyywtSk\&index=1\&list=PLkvomfn7GB0N_IHsSxwTB3o_L7mX KqXE8 (Exceções à Gravidade - Avner the Eccentric | Webdocs | CIRCOS 2015).

30 Exercício extraído do artigo "The sensitivity training clown workshop: Enhancing therapeutic Communication Skills in Nursing Students" de Betty L. Leef e Donna Hills (2013).
} 
essas emoções para si e agir da forma como agem quando se sentem desta maneira. O aluno, então, é solicitado a retornar à sala e interpretar o "clima emocional" da mesma. Este exercício vai um pouco além no que concerne ao desenvolvimento da awareness: treina os participantes não só a se colocarem presentes, mas a voltarem sua escuta, propositalmente, para perceberem o que se passa na relação, reconhecendo e legitimando o que quer que esteja acontecendo em nível de emoção e responsividade na relação com o outro.

Como podemos observar, exercícios como os supracitados permitem desenvolver as diversas habilidades implicadas em uma boa escuta: uma awareness aguçada, uma atitude expectante, um estado de disponibilidade e abertura, bem como uma capacidade de perceber e reconhecer o que se passa na relação, por exemplo.

Além desses exercícios, também é muito comum que o professor instigue e cobre a qualidade da escuta nas demais atividades. Se o sujeito está executando um exercício de palhaço, por exemplo, e alguém deixa cair algo estrondosamente no chão, este sujeito precisa reagir ao estrondo; caso contrário, é possível que o professor lhe chame a atenção ao final do exercício. Se o colega está propondo algo em um jogo de improviso em duplas e a outra pessoa não está "escutando", isto é, está agindo por conta própria, ignorando a lógica proposta, o professor pode até mesmo interromper o exercício para pedir que seja reiniciado. Tais atitudes, aos poucos, também vão aguçando a atenção do aluno para o desenvolvimento de sua própria escuta.

O desenvolvimento desta escuta, por sua vez, é importantíssimo ao timing cômico, pois implica na capacidade de o sujeito não só reconhecer e ser honesto com seus pensamentos e reações imediatas, como também de reconhecer o outro e colocar-se disponível para “jogar com” ele: ambos, processos importantíssimos para a sensibilidade de se "propor no momento 'certo' a coisa 'certa"' (noção de timing humorístico, proposta 
no capítulo 1). Neste sentido, vale a pena ressaltar que, mesmo não sendo exercícios de comicidade, muitos desses jogos de escuta levam a momentos cômicos, quando bem executados.

A seguir discutiremos alguns exercícios mais voltados para o desenvolvimento da forma cômica de pensar e se colocar no mundo.

c) Exercícios de incitação a reações e lógicas primárias: correspondem a exercícios que visam despertar no sujeito de maneira mais intensa as reações primárias e lógicas primeiras que, geralmente, são rapidamente descartadas em favor do raciocínio convencional. O objetivo destas atividades é permitir ao sujeito o acesso à sua capacidade cômica de agir e reagir de forma inesperada. Nesta direção, muitos destes jogos procuram provocar espontaneamente na pessoa reações primárias, como raiva, inveja, orgulho, alegria, receio, frustração; enquanto outros se dedicam a incitar saídas lógicas criativas que permitam a sobrevivência da pessoa dentro do exercício. A direção do professor é fundamental: ele pode provocar o aluno fazendo comentários que aticem ainda mais a vivência de uma determinada emoção ou o desenvolvimento de uma alternativa lógica inteligente.

Alguns exemplos de exercícios deste caráter são:

a. "Um tapinha não dói" ${ }^{31}$ : trata-se de uma versão alterada do pique-pega. O “pegador” deve dar um tapa na pessoa que está na sua mira; a pessoa que levou o tapa deve correr atrás de outro para se livrar do posto de pegador. As regras são: 1. Em hipótese alguma, a pessoa que levou o tapa pode revidar ou bater na pessoa que o bateu; 2. A pessoa que está na mira do tapa pode se salvar gritando o nome de outro participante, que, em consequência, vira o "pegador"; 3. O participante convocado pelo nome não pode gritar outro nome - deve

\footnotetext{
31 Exercício extraído de Oficina de Palhaçaria Iniciante oferecida por Denis Camargo entre outubro e dezembro de 2013, em Brasília, no Teatro Mosaico.
} 
tentar pegar alguém. Tal brincadeira não incita apenas a awareness dos alunos: os instintos de defesa contra o estímulo doloroso do tapa, bem como o sentimento de competitividade, de raiva e de vingança que tal jogo atiça costumam gerar reações bastante inusitadas e cômicas nos participantes.

b. "Pego no ato" 32. neste exercício o professor dá as seguintes instruções: "Vocês acordam de madrugada e estão com insônia, e, por isso, decidem ir para a sala e assistir um pouco de televisão. Mas você sabe que seu pai é bastante rígido e que, com certeza, ele iria te dar uma surra de cinto se o avistasse fora da cama àquela hora da noite. Você pode caminhar livremente pelo espaço e eu vou avisar quando o seu pai estiver vindo e você precisa rapidamente encontrar alguma forma de se esconder ou disfarçar, a fim de que ele não perceba que você está por ali. Já que é madrugada e está escuro, se você fizer um bom trabalho é possível que ele não te veja!". É importante ressaltar que todos fazem o exercício ao mesmo tempo, cada um na sua própria "viagem" imaginativa, e que o espaço da sala não deve ter muitos elementos, de modo que os alunos precisem rapidamente "se virar" para se disfarçarem de alguma forma.

É interessante notar como o exercício incita uma lógica primária - aludindo ao universo infantil e, ao mesmo tempo, causando uma situação de urgência que faz com que o aluno precise se apegar à primeira reação ou ideia que vier à mente.

O professor deixa que os alunos caminhem e, de repente, fala com urgência: “ele está vindo, você está ouvindo passos... chegou!”, e os alunos rapidamente

\footnotetext{
${ }^{32}$ Exercício extraído de Oficina de Palhaçaria Iniciante ministrada por Denis Camargo entre maio e julho de 2014, em Brasília, na Faculdade Dulcina de Moraes.
} 
se disfarçam como podem: alguns deitam no chão, outros imitam um objeto, e, uma vez, um colega da autora simplesmente tampou o rosto, seguindo a lógica das crianças pequenas que acreditam estar escondidos por não conseguirem ver nada - o que foi extremamente inesperado e engraçado na ocasião. Logo depois, o professor fala: "nossa, foi um engano, foi apenas o seu cachorro vindo nessa direção!”, ou algo parecido, apenas para, algum tempo depois, repetir o alerta. O exercício se repete algumas vezes para que a pessoa possa explorar suas diferentes possibilidades, esgotando as saídas mais óbvias e entrando em um estado expectante que permita a emergência de lógicas mais inusitadas.

c. Jogo dos cinco números ${ }^{33}$ : dois colegas se posicionam um na frente do outro, à distância de um braço, e iniciam a contagem: os alunos alternam na contagem, o aluno que ficar com os números ímpares deve pular ao pronunciar cada número, enquanto o aluno que está com os números pares apenas pronuncia o número. Ao pronunciar o número "cinco", o aluno deve fazê-lo dando um tapa na testa do colega, que não pode revidar ou tentar se proteger. Logo em seguida, recomeça a contagem, e o colega que estava com os números pares e apanhou agora começa a contar, estando com os números ímpares. O professor atua como juiz e, a cada erro, atribui pontos ao jogador que está sabendo executar a partida para poder provocar o "perdedor" e incitar reações no “ganhador". A cada ponto concedido, os jogadores devem se virar rapidamente para o público, compartilhando, através do olhar, como estão se sentido verdadeiramente. Este exercício também exige grande escuta dos participantes, pois se o jogo ficar muito agressivo, os colegas começam a se preocupar com

\footnotetext{
${ }^{33}$ Exercício extraído da dissertação de mestrado de Denis Camargo: Oliveira, D. C. (2012). Formação em palhaço: Reflexões sobre metodologias de formação de novos palhaços. Dissertação de Mestrado, Instituto de Artes - Universidade de Brasília, Brasil.
} 
os participantes, e a situação deixa de ser cômica. Contudo, tal jogo não envolve apenas uma awareness e uma atitude de honestidade com o público, mas também "gestos-em-fuga". Segundo Camargo (2012), muitas vezes a comicidade emerge da forma como se comporta o sujeito diante da antecipação do tapa e do sentimento de inevitabilidade com relação ao mesmo. Também outros sentimentos, como o de vitória, perda e vingança, costumam emergir inevitavelmente durante o jogo, de modo que pode ser bastante engraçado observar adultos tendo estes tipos de lógica e reações.

Tais exercícios, portanto, costumam ser bastante cômicos e, desta forma, conduzem os alunos a experimentarem sua própria comicidade: muitos deles podem se surpreender bastante com o potencial que têm de ser engraçados de forma natural e autêntica, caso simplesmente se entreguem às brincadeiras.

Como ressaltamos no início desta seção, não há receitas. Contudo, é por meio de exercícios desse tipo e pela orientação do mestre ou professor que, aos poucos, os alunos vão desenvolvendo não só habilidades e estados necessários à comicidade (amoralidade, awareness, honestidade, conexão, ludicidade), como seu próprio estado cômico. Afinal, conforme discutimos na introdução, é a partir da experiência destes estados e habilidades que, aos poucos, os sujeitos vão se familiarizando com seus caminhos vivenciais (corporificados), de modo a poderem acessá-los mais prontamente quando oportuno.

Em tempo, é importante destacar que tal treinamento não garante a emergência do humor na interação, pois ela dependerá, também, da relação que é estabelecida com o outro sujeito e das vivências e estados do mesmo no momento presente. No entanto, o treinamento do estado cômico possibilita ao participante maior sensibilidade e habilidade para distinguir quando e como desenvolver o humor, tornando mais provável sua emergência. 
Desta forma, compreendemos que os exercícios e condutas que constituem o treinamento de palhaço podem potencializar a sensibilidade e habilidade do psicoterapeuta para fazer uso do humor na clínica psicológica. A última seção deste capítulo discute sobre esta possibilidade.

\subsection{Contribuições do treinamento de palhaço para a clínica psicológica}

\subsubsection{Contribuições do clown para o desenvolvimento do senso de humor}

O treinamento de palhaço, da forma como vimos anteriormente, pode se constituir como uma importante ferramenta no desenvolvimento da capacidade humorística do terapeuta, principalmente por treinar a habilidade do sujeito de acessar:

1. Seus processos lógicos primários: como explicamos anteriormente, o treinamento de palhaço diz respeito a um jogo com nossa lógica primária - advinda dos primeiros estados, pensamentos e emoções que tomam conta do nosso corpo antes mesmo que tenhamos tempo de fazer uma reflexão consciente da situação. Essa lógica possibilita reações incomuns à situação, pois não se submete à lógica normativa da reflexão consciente. Contudo, ainda que se mostre incongruente em termos dos desdobramentos lógicos esperados, ao emergir espontaneamente no contexto da relação, esta lógica primária costuma fazer sentido para os envolvidos, mostrando-se surpreendentemente pertinente à realidade vivenciada.

Por outro lado, como vimos no capítulo 1, a vivência do humor envolve a criação de uma lógica inesperada que se utiliza de forma incomum do nosso senso comum sobre o que as coisas deveriam fazer e significar. Esta lógica surpreende-nos por possuir sentidos pertinentes à nossa realidade, ainda que seu modo de expressão seja subversivo à forma como usualmente nos colocamos diante do mundo e das 
situações. Neste sentido, um processo fulcral para a emergência do humor corresponde aos mecanismos lógicos (LM): os caminhos lógicos inesperados à forma como costumamos utilizar os fatos, coisas, ideias e palavras, mas cujo sentido é, de alguma forma, profundamente verdadeiro à realidade da troca cotidiana.

Deste modo, ao ensinar o sujeito a acessar seus processos lógicos primários no contexto lúdico do palhaço, o treinamento está ensinando-o sobre a criação dos mecanismos lógicos do humor, tornando-o mais proficiente na criação de experiências humoradas na relação.

2. Sua amoralidade: Já discutimos anteriormente sobre como a subversão humorada só pode acontecer a partir de uma relação mais honesta com a realidade, a qual, por sua vez, implica na dessacralização de nossos valores e crenças: passando a percebê-los não como verdades absolutas, mas pelo que verdadeiramente são valores e crenças. Somente a partir deste processo, é possível ao sujeito se distanciar das deduções que se seguem a esta normalidade instituída, e produzir saídas lógicas criativas e inesperadas à mesma. Como vimos anteriormente, o treinamento de palhaço é também um treino do desenvolvimento do estado de amoralidade, a partir do qual esta relação mais honesta se torna possível.

3. Seu estado lúdico: o universo lúdico é constituinte fundamental do humor. Neste sentido, já discorremos várias vezes até aqui sobre a importância de se adentrar o contexto da brincadeira para que uma saída lógica inesperada possa emergir e ser compartilhada, produzindo a experiência cômica na relação.

Quando ficamos mais velhos, nossas vivências lúdicas não apenas mudam de caráter, como também têm seu espaço cada vez mais restringido - principalmente 
devido à ideologia da seriedade, previamente discutida neste trabalho. Algumas pessoas praticamente perdem o contato com seu potencial lúdico em favor de uma vida "séria". Diante destas condições, a retomada do contato com a experiência lúdica através dos jogos da palhaçaria e seu contexto de brincadeira em muito contribuem para aumentar o potencial do sujeito de vivenciar e gerar humor. Especialmente, porque o humor é considerado uma das principais vias de contato com o universo lúdico quando a pessoa se torna adulta (Kupermann, 2003; Zanello, 2009).

Destarte, sustentamos que a capacidade cômica do terapeuta pode ser desenvolvida através de exercícios como aqueles dos treinos de iniciação ao palhaço.

Contudo, como pudemos observar, o treinamento do clown não corresponde apenas ao aprendizado de procedimentos cômicos, mas de uma série de atitudes, estados e qualidades que constituem uma forma cômica de se colocar diante da vida. Neste sentido, mais do que um treino de habilidades humorísticas, o treinamento de palhaço diz respeito a um treino do senso de humor.

Como vimos no capítulo anterior, o senso de humor não corresponde somente à capacidade de perceber ou criar coisas engraçadas, mas a uma forma humorada de encarar a vida. Enquanto forma de se situar no mundo, o senso de humor envolve, dentre outras coisas: uma postura aberta e responsiva nas relações; disponibilidade para rir de si mesmo; flexibilidade emocional e cognitiva; responsabilização por si próprio; aceitação dos diferentes momentos e processos que constituem a vida; bem como a capacidade de promover experiências de compartilhamento e pertencimento universal em suas interações.

Desta forma, o treinamento de iniciação ao palhaço se constitui como uma oportunidade para o desenvolvimento do senso se humor do psicoterapeuta, pois ele permite: 
- Desenvolver uma postura de aceitação e de responsabilização por si mesmo: de acordo com o que vimos no capítulo 2, o senso de humor envolve uma profunda atitude de aceitação, tanto com relação a si mesmo (com todas as suas falhas e virtudes), quanto com relação aos outros (com suas diferentes visões sobre o mundo e a realidade), e às situações e eventos que envolvem ambos - por mais adversos que sejam. Esta atitude de aceitação se aproxima muito a um estado de “reverência pelo que é" - o que não significa admitir tudo passivamente, mas reconhecer o que é inevitável e procurar tirar o melhor disto.

Neste sentido, como discutimos anteriormente, o senso de humor implica na aceitação de ambas as perspectivas cômicas e trágicas como partes do processo de viver, isto é: poder estar triste quando a tristeza é apropriada, sem se desestruturar, e sentir prazer em coisas felizes, sem perder o senso de perspectiva (Rutherford, 1994).

Esta atitude de aceitação, por sua vez, está profundamente relacionada à possibilidade de que o sujeito tome responsabilidade por sua própria vida. Isso porque apenas a partir de um reconhecimento de si, do outro e das situações, é que ele se torna capaz de fazer alguma coisa efetiva em relação às mesmas. Por outro lado, compreendemos que a figura do palhaço só existe mediante tais posturas de aceitação e responsabilização, uma vez que a honestidade é parte central de seu trabalho. Como coloca Chekhov (citado por Camargo, 2012), o ofício do palhaço permite o aprendizado de ser verdadeiro e sincero como nenhuma outra arte proporciona.

Neste sentido, o palhaço precisa estar pronto para aceitar e reconhecer o que quer que lhe aconteça, até mesmo as rejeições, compreendendo que elas fazem 
parte do processo de viver. Como vimos, seu treinamento implica no desenvolvimento desta postura, envolvendo exercícios:

- De desnudamento - que o impedem de negar suas dificuldades, ou desistir mediante o fracasso;

- De escuta - que demandam uma atitude de reconhecimento e aceitação da situação presente;

- De acesso a reações e lógicas primárias - os quais ensinam o sujeito a reconhecer os primeiros estados, emoções e pensamentos que emergem em sua relação com o mundo e ser sincero com eles.

Por outro lado, uma vez que o palhaço se coloca sinceramente presente na relação com o outro, sem defesas ou fingimentos, é possível afirmar que o sujeito que o vivencia se encontra ali por inteiro - isto é, inteiramente comprometido com a realidade como se faz presente para ele, sem preconceitos, máscaras ou suposições. E é por este comprometimento que podemos dizer que aprender a ser palhaço também é aprender a ser responsável por si: aceitar as condições presentes e se responsabilizar pelo que faz diante delas - inclusive pelos erros que pode cometer ou pelas dificuldades que pode apresentar.

- Aprender a rir de si mesmo: Como vimos no capítulo anterior, rir de nós mesmos significa voltarmos a estética humorada para a forma como vivenciamos nossas próprias características, situações e experiências, desenvolvendo: uma atitude de reconhecimento e aceitação perante as mesmas, um oportunismo inteligente diante de suas dificuldades, e um senso de 
vitalidade mediante a profunda crença na capacidade da vida de se reinventar a cada instante.

Neste sentido, como citamos no capítulo anterior, Rutherford (1994) afirma que rir de nós mesmos "significa que nós nos aceitamos tão erráticos, bobos e confusos quanto todas as outras criaturas são" (p. 217), ao passo que Kuhlman (1984) acredita que tal capacidade implica estar disposto a passar vergonha, perder seu status e até reverter a hostilidade sobre si mesmo quando for necessário. Desta forma, a disposição para rir de si mesmo está profundamente relacionada com um desnudamento de si e o desenvolvimento tanto de uma aceitação com relação ao seu ser em toda a sua totalidade (incluindo defeitos, fracassos e dificuldades), quanto de uma coragem para ser imperfeito. Tal processo se opõe completamente a uma atitude de negação das feridas e necessidades de mudança, a qual conduz o humor a ser utilizado como mecanismo de defesa ou como uma forma de "sermão" (escondendo-se atrás de uma postura moralista e voltando-se mais para uma exclusão do outro do que à promoção de um sentido de pertencimento).

O palhaço, por sua vez, como abordamos até aqui, implica justamente neste desnudamento e no desenvolvimento de um relacionamento com o nosso próprio ridículo marcado pela estética cômica. Seu treinamento implica nos despirmos dos mecanismos de defesa e das máscaras sociais para confrontarmos as inseguranças, os fracassos e as inadequações que fazem parte do nosso ser mostrando como se pode não só sobreviver a um encontro aberto com os mesmos e aceitá-los como parte da nossa condição, como também desenvolver uma atitude de superação com relação aos mesmos, reconhecendo o potencial cômico das reações e lógicas inesperadas que emergem de suas experiências. 
Neste sentido, o treino de iniciação do palhaço pode ser compreendido, fundamentalmente, como um aprendizado de como rir de si mesmo.

- Desenvolver abertura e responsividade: Também vimos no capítulo 2 que o senso de humor envolve uma postura aberta e responsiva com relação ao meio, isto é, a capacidade de estabelecer um contato genuíno com o mundo. De acordo com Hycner (1995), o sujeito só consegue desenvolver esta abertura quando se despe de suas defesas e se coloca de forma íntegra e disponível nas relações. Para o autor, um Self ${ }^{34}$ coeso e integrado é parte fundamental desta disponibilidade.

Como analisamos no segundo capítulo, o processo de integração do Self envolve o desenvolvimento de uma awareness por parte do sujeito quanto aos seus estímulos internos (sentimentos e impulsos) e às necessidades ou demandas do meio - por mais difíceis e contrários que ambos sejam ao seu Self ideal (Jacobs, 2009). Esta awareness permitirá que a pessoa reconheça, organize e integre os diferentes aspectos de sua vida, passando a perceber de forma mais realista as questões vivenciadas e, por conseguinte, estabelecendo uma relação mais genuína com o mundo.

Neste sentido, o treinamento de clown em muito contribui para este processo de awareness e integração: seus exercícios de desnudamento permitem o contato com partes do nosso Self tão bem escondidas que, muitas vezes, nem sequer lembrávamos ou sabíamos que existiam - nos ensinando a lidar com a vulnerabilidade que emerge desta exposição de forma leve e confiante. Além disso, seu treino também permite: o desenvolvimento de um estado de receptividade e escuta ao outro, bem como o estabelecimento de uma postura de

\footnotetext{
${ }^{34}$ Como destacado no capítulo 2, o Self, neste trabalho, é definido como a organização única de cada pessoa enquanto ser no mundo (Hycner, 1995; Richman, 2001).
} 
prontidão (correspondente a uma atentividade aguçada não só com relação a si próprio, como também com relação ao meio). A abertura e disponibilidade provocada por estes processos, por sua vez, forjam no sujeito uma sensibilidade excepcional para o contato humano, a qual vai refletir em sua proposta cômica.

Em outras palavras, uma vez que o palhaço implica nesta postura aberta e disponível, sua comicidade forja maior awareness e conexão com o mundo, de modo que é possível afirmar que a lógica cômica do palhaço não faz uso do humor para fins de deflexão - desvio ou difusão de contato com o momento presente. Aprender os caminhos cômicos do palhaço, portanto, permite ao psicólogo o desenvolvimento de uma habilidade humorística que potencializa o contato com as questões presentes e não a fuga das mesmas.

- Compartilhar e celebrar os erros, as dificuldades e as lutas cotidianas como parte da condição humana: o senso de humor envolve uma disposição para celebrar e compartilhar os erros, fracassos e lutas que fazem parte da humanidade, implicando em uma visão afetuosa com relação às manias e loucuras que constituem a condição humana (Kuhlman, 1984; Richman, 2001). Neste sentido, como vimos no capítulo 2, a comicidade que emerge do senso de humor trata de experiências comuns à humanidade, potencializando o sentimento de pertencimento dos sujeitos e contribuindo para integrá-los à comunidade.

Da mesma forma, como discorremos anteriormente, o palhaço compartilha de maneira cômica o ridículo que constitui a nossa natureza humana. Sua existência corporifica experiências de fracassos, inadequações, dificuldades, as quais têm feito parte do processo de viver do homem, independentemente do tempo ou comunidade em que vive. Assim sendo, é muito comum que os autores afirmem que humor gerado pelo clown é um humor de identificação 
(Berky \& Barbre, 2000; Camargo, 2012; Koller \& Grisky, 2007): suas reações e lógicas primárias envolvem sentimentos, pensamentos e urgências que habitam o âmago da natureza humana - de modo que, por mais absurdas que sejam à moral vigente, elas fazem sentido em algum nível e levam ao riso.

Neste sentido, a lógica cômica do palhaço tem o potencial de gerar um profundo sentido de pertencimento.

Destarte, mediante a discussão acima, é possível afirmar que o treinamento de iniciação à palhaçaria pode favorecer o desenvolvimento do senso de humor daqueles que dela participam, apresentando-se como uma potencial ferramenta para o desenvolvimento do senso de humor do psicoterapeuta.

\subsubsection{Contribuições do clown para outros aspectos característicos da clínica psicológica}

Além dos processos característicos do senso de humor, o treino de iniciação ao clown também pode proporcionar ao terapeuta o desenvolvimento de outras posturas fundamentais ao andamento da psicoterapia - as quais, como se viu no capítulo 2, são imprescindíveis ao uso terapêutico do humor. São algumas delas:

- Autenticidade: como tratamos previamente, a autenticidade do terapeuta é um dos fatores essenciais para o estabelecimento de uma relação genuína com o paciente e é fundamental para que o uso do humor na psicoterapia não acabe se voltando aos interesses do terapeuta de encobrir determinado desconforto ou dificuldade.

Por outro lado, a figura do clown tem como cerne a autenticidade: seu trabalho envolve diretamente o reconhecimento dos estados, emoções e pensamentos espontâneos que emergem de suas relações com o mundo. Como 
afirma Dimitri (citado por Oliveira, 2008), o palhaço põe em jogo a si mesmo sem poder trapacear.

Assim sendo, conforme expusemos, faz parte do treinamento do palhaço a quebra de barreiras que impeçam um contato significativo da pessoa consigo e com o outro. Essas barreiras possuem como foco principal esconder e evitar medos, receios, marcas, dificuldades e inseguranças que fazem parte da nossa existência. No treinamento, a pessoa é posta em contato com os mesmos a partir da ideia de que pode sobreviver a este contato: ela é direcionada de modo a não desistir de suas proposições e a acreditar em si mesma, independente do sucesso ou fracasso destas propostas. Como vimos, tal direcionamento dentro desses exercícios possibilita, por sua vez, o aprendizado de uma outra forma de lidar com a vulnerabilidade inerente à existência humana, bem como o crescimento de uma confiança em si que não seja pautada no sucesso ou na negação, mas na sua própria integridade e capacidade de reerguer-se perante as constantes lutas com o mundo.

Desta forma, o treino do clown pode permitir a experimentação de uma postura mais autêntica na relação, caminho que o terapeuta pode levar também para suas relações na clínica.

- Calor humano: como explicamos no capítulo anterior, este fator terapêutico não é muito explorado pelos autores, mas envolve, segundo Isolan et al. (2008), uma postura de reconhecimento, carinho, apoio, preocupação e compaixão para com o outro.

Neste sentido, o clown emana calor humano em sua essência: de acordo com o que argumentamos, ele trabalha na construção de uma relação de cumplicidade com o outro, reconhecendo e respeitando sua alteridade. O palhaço possui um 
profundo compromisso com o momento presente, de modo que se importa com sua realidade e leva a sério suas relações. Neste sentido, é um ser preocupado e cuidadoso. Seu treinamento ensina esta cumplicidade através dos exercícios de desnudamento e de escuta, pois estes trabalham tanto o compromisso com a honestidade, como o reconhecimento do outro sem julgamentos e predeterminações - aceitando aquilo que este outro propõe no momento presente, e a forma como esta proposta afeta a situação e os demais.

- Empatia: para Berky e Barbre (2000), a linha de palhaçaria aqui discutida tem como cerne a empatia. Conforme foi tratado no capítulo 2, a experiência empática consiste em "sentir 'dentro' do outro" e implica na mobilização intensa do próprio Ser em direção à existência de outra pessoa, ao mesmo tempo em que se mantém centrado em si. Tal movimento permitiria ao sujeito compreender a forma como o outro vivencia e percebe o mundo sem perder o seu próprio senso de Self, reconhecendo a alteridade deste outro. Neste sentido, o clown demanda certos tipos de habilidade e envolve certos processos que favorecem a construção de uma atitude empática, como é o caso da awareness com relação aos demais e da capacidade de partir do lugar existencial em que estes se encontram para propor algo. Como ressalta Bob Berky (Berky \& Barbre, 2000), ser palhaço "é procurar entender estando com $^{35 "}$ (p. 242).

A empatia, por sua vez, conforme vimos, é uma qualidade relacional substancial no uso psicoterapêutico do humor (Greenwald, 1975; Kuhlman, 1984; Kupermann, 2003; Panichelli, 2013; Richman, 1996; Sultanoff, 2013).

- Curiosidade e atitude expectante: uma postura de curiosidade por parte do terapeuta é outro fator considerado fundamental para o sucesso das

\footnotetext{
${ }^{35}$ Grifo da autora.
} 
intervenções. Segundo Richman (2001), curiosidade significa estar aberto a experiências e se interessar por diferentes ideias, mesmo que não se concorde com elas. Esse autor compreende que esta abertura implica uma postura de "não saber", e nesse sentido cita o poeta americano Alexander Pope: "Algumas pessoas nunca aprenderão nada, porque elas entendem tudo muito rápido” (p. 424).

Do mesmo modo, Hycner (1995) sublinha a importância de que o terapeuta se esvazie dos conceitos tidos como verdade e se abra à possibilidade de surpreender-se. Esse autor afirma que, de certo modo, nós, terapeutas, muitas vezes, "sabemos demais". Para ele, as expectativas do terapeuta sobre o que deveria ocorrer na sessão sempre interferem no que pode acontecer, de modo que pré-julgar seria cortar a emergência de novas possibilidades:

O terapeuta não pode entrar verdadeiramente no mundo do cliente e estar "presente" a menos que esteja disposto a "suspender" seus pressupostos, sua própria visão de mundo e conceitos tanto quanto for humanamente exequível no momento. É claro que não pode suspender completamente as próprias perspectivas e nem seria desejável. Mas é necessário que nossos vieses e preconceitos sejam “colocados em parênteses” (p. 68).

Mas como podemos aprender a colocá-los entre parênteses? O palhaço viabiliza uma possibilidade através do desenvolvimento da amoralidade. Como vimos anteriormente, o clown permite o desenvolvimento de um outro tipo de relacionamento com os conhecimentos, pressupostos e verdades estabelecidas, “dessacralizando-os” (Dorneles, 2003), isto é, compreendendo-os apenas como uma possibilidade de produção sobre a realidade dentro das diversas 
possibilidades e potenciais que a realidade oferece. Como citado, para o clown não existem fatos eternos ou verdades absolutas (Matraca et al., 2011).

O procedimento de despimento que acompanha este processo de dessacralização implica no abandono de uma postura defensiva - pautada em um "saber" que dá a ilusão de controle - para o desenvolvimento de uma atitude de "não saber e não fazer" que constitui a postura expectante. Como vimos, estes processos são forjados pelo treinamento de iniciação à palhaçaria e favorecem a capacidade do sujeito de "jogar com" o outro no uso do humor.

- Capacidade de improvisação (criatividade e imaginação): para Keeney (1995), uma vez que aquilo que emerge de cada encontro com o paciente é de natureza imprevisível, o trabalho do terapeuta implica uma grande capacidade de improviso. Segundo esse autor, "a participação do terapeuta no drama de uma sessão torna-se um convite à improvisação" (p. 15-16).

Para Keeney (1995), improvisar é ser criativo com o que se tem no momento, a partir do que já se sabe: “os terapeutas que se utilizam da improvisação procuram menos ser fiéis aos textos e instituições do que experimentar, aplicar e compartilhar a inventividade criativa de sua própria imaginação" (p. 20).

Segundo discutimos brevemente no capítulo anterior, cultivar a criatividade e a imaginação é de fundamental importância para o sucesso do empreendimento psicoterapêutico, pois possibilita a percepção e criação de novas formas de lidar com os problemas e recursos que o paciente apresenta.

O palhaço, por sua vez, de acordo com o que apresentamos neste capítulo, implica no treino do improviso e da habilidade de "jogar com" - os quais envolvem o desenvolvimento de qualidades como: prontidão e awareness, 
flexibilidade, construção de saídas lógicas criativas, imaginação, presença e abertura ao diálogo.

Neste sentido, o treinamento de iniciação ao palhaço pode incitar no terapeuta sua capacidade criativa, bem como desenvolver sua inclinação ao improviso.

Portanto, mais do que a capacidade de produzir humor, o treinamento na linha de palhaçaria aqui abordada favorece o descobrimento e desenvolvimento de uma habilidade cômica engendrada por condutas e estados com qualidades essencialmente terapêuticas. Desta forma, uma das possibilidades para que o terapeuta aprenda a criar intervenções humoradas de forma intencional e sensível seria um treinamento constituído com base nos treinos de iniciação à palhaçaria.

Isto não significa inferir que o terapeuta deva encarnar seu palhaço nos atendimentos, muito menos que precise se tornar um clown profissional caso deseje desenvolver suas habilidades de uso do humor no contexto da psicoterapia. No entanto, sugerimos a possibilidade de que um treinamento pautado nos exercícios da palhaçaria possibilite ao psicoterapeuta descobrir e afiar caminhos vivenciais que permitam o desenvolvimento de sua sensibilidade para fazer surgir experiências cômicas terapêuticas na relação. Neste sentido, o psicoterapeuta não se torna um palhaço, mas conserva em si a marca dos estados, das possibilidades de vida e das habilidades que experimentou ao longo desse treino, podendo levá-las para sua prática clínica.

\subsection{Algumas ressalvas}

Como vimos neste capítulo, a figura do palhaço tem emergido em contextos de cura em muitos momentos diferentes da história da humanidade. Mais do que isso, Van Blerkon (1995) ressalta que o clown tem sido muito associado à cura psicológica, uma vez que em 
diversos momentos, sua figura ocupou o papel do curandeiro - agente social e cultural que, diferentemente dos médicos ocidentais modernos, confere lugar de destaque às dimensões pessoais, sociais e culturais na experiência do adoecimento e nos processos de cura.

Neste sentido, não é tão surpreendente que o humor do palhaço possua certas características terapêuticas. Contudo, isto não significa que seu treinamento conduza ao aprendizado específico do uso do humor na clínica psicológica, uma vez que, como vimos no capítulo 2 , a compreensão do que pode ser terapêutico ou não para uma pessoa e do lugar que o humor ocupa nesse contexto implicam um conhecimento especializado. Em outras palavras, as noções, práticas, técnicas, metodologias e a ética que constituem a práxis psicológica precisam ser integradas nas experiências de aprendizado do uso psicoterapêutico do humor. Este conhecimento, por sua vez, influenciará na utilização dos caminhos cômicos aprendidos com os exercícios, isto é: nas intenções que irão permear a criação do humor no contexto da relação com um determinado paciente.

Desta forma, faz-se importante ressaltar que o treinamento de iniciação à palhaçaria oferece a oportunidade de descobrimento de alguns dos caminhos vivenciais que constituem o estado cômico; contudo, cabe ao terapeuta buscar acessá-los e utilizá-los no contexto clínico. É possível, também, aventarmos sobre a possibilidade de construção de um treinamento de humor direcionado ao psicoterapeuta, mas pautado nos princípios e processos da palhaçaria.

Atualmente, no que concerne ao uso dos princípios e habilidades do clown no treinamento destinado a outras profissões, encontramos apenas um estudo norte-americano - o qual avaliou uma proposta de incorporação de técnicas da palhaçaria em um treinamento de sensibilidade destinado a futuros enfermeiros pediátricos (Leef \& Dallas, 2013). A Oficina de Treinamento de Sensibilidade com Palhaços (Sensitivity Training Clown Workshop - STCW) visava: a) potencializar a awareness do estudante para sua 
linguagem corporal pessoal; b) ensinar o mesmo a interpretar a linguagem corporal de pacientes pediátricos e medir o clima emocional do quarto de uma criança; c) ajudar estudantes a desenvolver relacionamentos de confiança com crianças e seus familiares. Os pesquisadores chegaram à conclusão de que tal oficina oferecia uma possível solução ao desafio dos educadores de ensinar estudantes de enfermagem a serem comunicadores sensíveis e terapêuticos.

Na psicologia, nenhum estudo neste sentido foi realizado até o momento. Contudo, alguns programas de treinamento de habilidades humoradas aparecem na literatura sobre o uso do humor na psicoterapia, como é o caso do programa de treinamento do senso de humor do Paul Mcghee (Cai et al., 2014; Franzini, 2001), das oficinas de "humordrama" de Walter O’Connell (Saper, 1987) e do Treinamento de Imersão no Humor, de Waleed Salameh (Franzini, 2001).

O treinamento de Mcghee diz respeito a uma espécie de manual composto de oito passos, cada passo contendo uma breve descrição teórica, seguida por uma lista de exercícios a serem praticados ao longo da semana para desenvolver as habilidades associadas a esse passo. Esses passos consistiam em: 1) determinar a natureza do senso de humor e se cercar de humor; 2) tornar-se mais brincalhão e aprender a não se levar tão a sério; 3) rir mais frequentemente e aprender a contar piadas ou histórias engraçadas; 4) brincar com a linguagem, "pegadinhas", palavras sem sentido e exageros; 5) encontrar ironias e coincidências humoradas no cotidiano; 6) tomar-se levemente e rir de seus próprios erros; 7) encontrar humor em situações estressantes; 8) usar o humor para sobreviver e como mecanismo de coping (Cai et al., 2014). Contudo, vale ressaltar que este programa também não é direcionado às particularidades da prática psicoterapêutica, e o fato de corresponder a um manual faz com que não apresente nenhuma ferramenta 
dialógica para auxiliar o indivíduo a lidar com as dificuldades e bloqueios que eventualmente emerjam no processo.

Já o "humordrama" e o Treino de Imersão são treinamentos presenciais voltados aos psicoterapeutas. O primeiro foi citado em um artigo de Saper (1987), mas não encontramos nenhuma informação sobre o mesmo, seja em ferramentas de busca acadêmicas ou populares da internet. O segundo - Treinamento de Imersão no Humor, de Waleed Salameh - de acordo com Franzini (2001), corresponde a um treinamento de criação e desenvolvimento do humor para terapeutas, que inclui: técnicas de produção de humor; aulas teóricas sobre o seu lugar na psicoterapia; exercícios e role-playing; bem como dicas de como criar um ambiente voltado ao humor no espaço clínico. Não houve qualquer menção na literatura aqui abordada sobre um treinamento deste caráter no Brasil, embora seja possível que existam terapeutas que executem workshops com este tema em eventos específicos.

Neste trabalho, escolhemos explorar o treinamento de iniciação ao palhaço como possibilidade de desenvolvimento da intencionalidade no uso do humor pelo psicoterapeuta. Se por um lado, o clown possui qualidades, processos e princípios que podem contribuir no desenvolvimento de uma profunda sensibilidade no uso do humor na relação, no aumento do senso de humor pela pessoa que o pratica, e no aprendizado de habilidades cômicas em geral; por outro lado, não existe, até o presente momento, qualquer estudo ou literatura que conecte a figura do palhaço ao uso do humor na psicoterapia.

Neste sentido, o presente capítulo visou explorar como as qualidades, atitudes e estados implicados no treinamento do clown poderiam contribuir para o desenvolvimento de um senso de humor mais aguçado por parte do psicoterapeuta, de modo a potencializar a capacidade do mesmo de utilizar o humor intencionalmente e sensivelmente na clínica. 
Não obstante, seriam necessários estudos práticos para confirmar essa possibilidade e averiguar o real impacto de tal treinamento no desenvolvimento dos processos e habilidades acima exploradas não só no contexto do palhaço, mas de forma que pudessem ser generalizadas para o cotidiano do psicoterapeuta e para demais contextos em que transita, inclusive o da prática clínica.

\subsection{Considerações finais}

Como vimos, o humor possui um lugar central na psicoterapia, não apenas enquanto intervenção pontual - correspondente a uma determinada experiência humorística vivenciada - mas enquanto paradigma - referente ao senso de humor e o seu lugar enquanto objetivo terapêutico e postura fundamental a ser assumida pelo psicoterapeuta.

O presente capítulo visou endereçar alguns dos questionamentos realizados ao longo deste trabalho acerca da possibilidade de desenvolvimento das habilidades humorísticas por parte do psicoterapeuta, tais como: o humor poderia ser usado de forma intencional pelo psicoterapeuta ou aconteceria apenas de forma espontânea? O psicoterapeuta poderia aprender a utilizar o humor na clínica de forma intencional e sensível? Poderia ele desenvolver seu senso de humor? Caso sim, como?

De acordo com o que discutimos, o humor é um fenômeno inter-humano que envolve uma série de qualidades e processos relacionais implícitos que só acontecem na própria experiência humorada. Neste sentido, não é possível que o sujeito tenha um controle consciente e direto sobre a emergência do humor na relação, mas é possível que ele aprenda a acessar um estado cômico - isto é, uma forma cômica de se relacionar com o mundo, cujos processos e qualidades configurem uma sensibilidade e habilidade para fazer proposições cômicas na relação. 
Nesta direção, a criação proposital do humor não envolve apenas uma intenção racional, mas necessita de uma intenção implícita, visceral, que emerge de um conhecimento corporificado desenvolvido por meio da prática humorada. Esta prática não viabiliza um controle direto do estado cômico, senão uma apropriação de suas qualidades, nuances e habilidades, de modo que os caminhos vivenciais para a proposição do humor e as intenções que os permeiam se tornem mais familiares.

Neste capítulo exploramos a possibilidade de tal prática humorada por meio do treinamento do palhaço. O palhaço é uma figura cômica milenar que tem assumido diferentes imagens e ocupado diferentes contextos e papéis sociais ao longo da história, em diversas culturas e sociedades. Dentre os principais processos e qualidades que caracterizam o seu trabalho, estão: a) a autenticidade e o contato com as lógicas e reações primárias que constituem saídas lógicas inesperadas; b) um estado de "amoralidade" "dessacralizando" as lógicas e normas comuns, sem ignorá-las; c) uma escuta aguçada e uma atitude empática - mostrando reconhecimento e curiosidade perante a alteridade das pessoas com quem se relaciona; d) afinidade com o universo lúdico e a capacidade de “jogar com"; e) a lida com o próprio ridículo a partir da estética cômica - em uma atitude de confiança em si e na vida.

Como vimos, o aprendizado dessas atribuições implica não somente o desenvolvimento de habilidades e procedimentos cômicos - isto é, o ensino visceral dos processos e qualidades relacionais envolvidos na criação de mecanismos lógicos humorados (LM). Envolve, também, uma série de atitudes e estados que constituem o que definimos no capítulo 2 como "senso de humor" - forma humorada de encarar a vida que requer, dentre outras coisas: uma postura aberta e responsiva nas relações; disponibilidade para rir de si mesmo; flexibilidade emocional e cognitiva; responsabilização por si próprio; aceitação dos diferentes momentos e processos que constituem a vida; bem como a 
capacidade de promover experiências de compartilhamento e pertencimento em suas interações.

Neste sentido, compreendemos que o treinamento de palhaço pode oferecer importantes ferramentas no desenvolvimento da capacidade e sensibilidade cômica do psicoterapeuta quando ocorre junto à compreensão do lugar que o humor ocupa dentro dos princípios e peculiaridades que constituem a práxis psicológica. Contudo, seriam importantes estudos empíricos que pudessem confirmar e explorar esta proposta, bem como a criação de espaços práticos que, de fato, viabilizassem a execução daquilo que, aqui, foi explorado apenas de forma teórica.

Uma vez que uma das críticas deste capítulo concerne justamente à ausência de proposições concretas sobre como o psicoterapeuta poderia desenvolver sua capacidade e sensibilidade cômicas, e a fim de complementar as discussões teóricas aqui desenvolvidas, trabalhamos na construção de um blog que possibilitasse aos leitores o acesso tanto a alguns vídeos de trabalhos de palhaço que melhor ilustrem os princípios aqui discutidos, como a divulgação de trabalhos, oficinas e iniciações de palhaço que, por ventura, se façam disponíveis no país, para os psicoterapeutas que se interessarem pelo tema, o qual pode ser acessado em https://clownepsicoterapia.wordpress.com/. 


\section{Conclusões}

The attempt to develop a sense of humor and to see things in a humorous light is some kind of a trick learned while mastering the art of living ${ }^{36}$.

Viktor Frankl

O humor integra a vida e o cotidiano dos mais diversos povos e sociedades. Ele corresponde a um fenômeno inter-humano, cujos sentidos, formas de expressão e contextos de emergência variam de cultura para cultura e de tempos em tempos.

É possível observarmos diversas contribuições ao longo da história com relação à compreensão do humor e de suas particularidades. Contudo, a ausência de diálogos e articulações entre esses esforços impediu a criação de uma definição compreensível do humor e uma maior clareza dos processos e qualidades que caracterizam sua emergência.

Neste trabalho, articulando as contribuições de importantes estudiosos do humor, pudemos chegar a algumas conclusões com relação aos principais processos e vivências que constituem a sua emergência. São eles:

- O lúdico: o humor, enquanto relação, caracteriza-se como um jogo. Somente quando aceitamos brincar é que podemos compartilhar de sua experiência e processos particulares. Enquanto vivência lúdica, o humor: possui um caráter essencial de diversão e consiste em uma experiência essencialmente voluntária (não pode ser forçada); implica um envolvimento primário do nosso ser que toma parte corporalmente, mentalmente e imaginativamente na brincadeira; envolve uma vivência espacial e temporal própria (alteração das referências eu-

\footnotetext{
36 Tradução nossa: "A tentativa de desenvolver o senso de humor e de ver as coisas sob uma luz humorada é algum tipo de truque aprendido enquanto aprendendo a arte da vida".
} 
mundo), com regras particulares (princípios cooperativos próprios); e tende a formar um sentido de comunidade entre aqueles que jogam juntos e compartilham sua vivência.

- Os processos de incongruência-resolução: o humor emerge de um processo de incongruência entre uma linha de pensamento (script) que segue nosso senso comum do que as coisas deveriam fazer e significar, e uma linha de pensamento inusitada. Esta incongruência, por sua vez, envolve um processo de resolução, isto é: um caminho de sentido inusitado que une ambas a linhas de pensamento, de uma forma surpreendente. Neste sentido, o humor consiste no processo de criação desta saída lógica inesperada que usa de forma incomum o senso comum que temos do que as coisas deveriam fazer e significar - unindo duas linhas de pensamento usualmente disparates. Faz-se importante ressaltar, contudo, que estes processos de incongruência-resolução que geram a experiência humorada não são de natureza apenas cognitiva, mas emocional, cinestésica e afetiva, de modo que fazem parte das atividades e formas de vida de uma pessoa e sua sociedade, tendo aspectos culturais e os contextos relacionais como partes integrais de seus processos. É por isso, inclusive, que podemos compreender uma piada (cognitivo) sem achá-la engraçada e também o motivo pelo qual certas piadas e trocas humoradas não encontram traduções satisfatórias para outras línguas e sua cultura.

- O timing: o humor envolve ainda um senso de como propor a coisa certa na hora certa, de modo a gerar a experiência humorada. Este timing cômico é importante pois dele depende a entrada da pessoa em uma vivência lúdica, bem como a criação de uma incongruência e a emergência de saídas lógicas inesperadas à mesma na relação. 
- A experiência estética cômica: a estética diz respeito às experiências nas quais nos encontramos envolvidos de corpo e mente e remete à forma como o mundo nos afeta e nós o afetamos antes mesmo que possamos formular significados exprimíveis em palavras. O humor consiste em uma experiência estética particular, isto é, uma forma particular de se engajar no mundo, de afetar e ser afetado por ele. A forma cômica de se situar no mundo é marcada pela celebração da capacidade da vida de se reinventar a cada instante; pela senciência - um puro sentido de vida, que resulta em um estado presente e em uma relação contingente com o mundo (sem condenações eternas ou verdades absolutas); bem como por um oportunismo inteligente diante das situações.

Deste modo, podemos compreender o humor como uma experiência lúdica a qual envolve a criação de uma lógica inesperada que se utiliza de forma incomum do senso comum sobre o que as coisas devem fazer e significar, unindo linhas de pensamento usualmente disparates. Esta lógica surpreende-nos por possuir sentidos pertinentes à nossa realidade, ainda que seu modo de expressão seja subversivo à forma como usualmente nos colocamos diante do mundo e das situações.

O humor, segundo nossas discussões, também pode ser caracterizado como um estado interno. Neste sentido, mais do que o momento de troca que gera uma experiência engraçada - como na definição acima -, o estado humorado corresponde a uma forma de ser e estar no mundo que favorece o fenômeno do humor, isto é, permite ao sujeito maior disponibilidade e sensibilidade para engajar-se em trocas humoradas. Essencialmente, o estado cômico implica processos e qualidades relacionais pautados na estética cômica (na forma cômica de se situar no mundo e nas relações).

Por fim, temos também o senso de humor - que corresponde a uma postura geral com relação ao mundo que se desenvolve quando o sujeito passa a assumir a estética 
humorada enquanto seu modo de vida. Um modo de vida bem humorado envolve: um maior comprometimento com a realidade presente na forma como a percebemos e vivenciamos; maior aceitação de si, do outro e das situações, compreendendo também os erros e as tristezas como parte do processo de viver; coragem para ser imperfeito; abertura ao diálogo e responsividade com o mundo; disposição e oportunismo inteligente para lidar com as dificuldades; flexibilidade emocional e cognitiva; e uma relação de contribuição e compartilhamento com a comunidade, promovendo experiências de pertencimento universal em suas interações. Por estas qualidades, autores como Rutherford (1994) e Richman (2001) consideram o senso de humor como parte integral de um estilo de vida saudável.

Por consistir em uma dimensão interativa essencial da humanidade e parte integral das atividades e formas de vida que constituem nosso cotidiano, o humor deve integrar também as relações e trocas estabelecidas na clínica psicológica. Contudo, uma das maiores dificuldades que esta integração enfrenta concerne à "ideologia da seriedade" (Neves, 1974), ainda prevalente na sociedade ocidental, permeando o paradigma psicoterapêutico.

A ideologia da seriedade associa o "sério" a uma atitude de arrogância, rigidez e sisudez, compreendendo-a como diretamente relacionada à maturidade, responsabilidade, e à apropriação da realidade. Diante desta ideologia, o humor - interativo, ambíguo e lúdico - torna-se sinônimo de imaturidade, descompromisso e superficialidade.

Muitos psicoterapeutas ainda valorizam este ideal de seriedade (introjetado ao longo de sua vida e de sua formação) - compreendendo-o como sinônimo de comprometimento, precisão e profissionalismo. Contudo, ao fazê-lo, não só deixam de fora do setting psicoterapêutico uma dimensão interativa essencial do nosso Ser (o humor), como 
apresentam uma rigidez pouco saudável à troca terapêutica (Chazenbalk, 2005; Kuhlman, 1984).

Não obstante, como pudemos constatar, a relação entre humor e seriedade é muito mais complexa do que aquela entre opostos, e pede a desmistificação de algumas ideias:

1. A emergência de uma troca humorada ou até mesmo do senso de humor são pautados em uma relação lúdica com a realidade, mas isto não significa necessariamente um menor contato com a mesma: a razão lúdica propicia grande envolvimento e troca imaginativa com a realidade, de modo que confere às relações humoradas grande potencial de diálogo e reelaboração dos elementos que permeiam nossa vida (Kupermann, 2003). Além disso, sua qualidade estética propicia o engajamento do sujeito com o mundo em uma intensidade maior do que a comum, e evita resistências. Este potencial, contudo, pode ser utilizado tanto para distrair a pessoa de processos e questões importantes, como para conduzi-la a aprofundá-los.

2. Se por um lado, a ambiguidade e o caráter de brincadeira do humor podem ser utilizados para se descomprometer de uma troca com o outro, por outro, não é possível que o sujeito se omita completamente das ações humoradas que tomou e das mensagens que transmitiu, de modo que a crença de que o humor permite enganar os outros, na maior parte do tempo, é apenas um preconceito advindo da ideologia acima apontada.

3. Com relação à crença de que o humor possui uma característica de negação e desrespeito aos valores e regras que organizam a sociedade, faz-se importante ressaltar, como Corrigan (1983) aponta, que tanto a seriedade como o humor correspondem apenas a atitudes diferentes com relação a esses valores. Enquanto o sério institui diretamente os sistemas de valores que definimos e aceitamos como 
verdade, o humor aceita esses valores para, em seguida, subvertê-los. Esta subversão pode ou não ser respeitosa e terapêutica.

Neste sentido, consideramos o humor como um Phármakon: "palavra grega que aponta para a potencialidade de uma substância que pode realizar-se como remédio e como veneno" (Zanello, 2005, p. 221). A fim de que a emergência deste fenômeno possa assumir um lugar saudável na clínica psicológica, potencializando os processos terapêuticos, é fundamental que o psicoterapeuta desenvolva seu senso de humor, bem como algumas outras características centrais ao seu papel como: a autenticidade, a empatia e o calor humano (Richman, 2001; Sultanoff, 2013). Mais do que isso, também é importante que ele compreenda o lugar que o humor ocupa nos meios, objetivos, processos e condições que configuram o empreendimento da psicoterapia.

No que concerne à compreensão deste lugar, criamos aqui um quadro (Quadro 6) que ressalta alguns aspectos importantes do que discutimos ao longo do trabalho - sobre o que pode caracterizar o uso do humor como terapêutico ou não no que diz respeito às especificidades da práxis psicoterapêutica: 


\section{Quadro 6}

O lugar do humor no setting psicoterapêutico.

\begin{tabular}{|c|c|}
\hline O humor pode ser terapêutico quando & O humor pode ser prejudicial quando \\
\hline $\begin{array}{l}\text { atua com "reverência pelo que é" - para um } \\
\text { profundo reconhecimento e aceitação de si, do } \\
\text { outro e das situações, inclusive nos aspectos que } \\
\text { precisam de transformação. }\end{array}$ & $\begin{array}{l}\text { atua como resistência ou mecanismo de defesa - } \\
\text { enquanto negação das feridas e necessidades de } \\
\text { mudança. }\end{array}$ \\
\hline $\begin{array}{l}\text { possibilita uma awareness mais completa do } \\
\text { sujeito com relação aos seus estímulos internos, } \\
\text { às necessidades e demandas do ambiente, às suas } \\
\text { relações com o meio e a questões terapêuticas } \\
\text { importantes. }\end{array}$ & $\begin{array}{l}\text { implica desvios ou difusões no contato íntegro da } \\
\text { pessoa consigo, com o outro ou com questões que } \\
\text { precisam ser endereçadas na terapia. }\end{array}$ \\
\hline $\begin{array}{l}\text { subverte valores rígidos que têm prejudicado a } \\
\text { flexibilidade da pessoa para a resolução de } \\
\text { problemas, seu contato com recursos pessoais e } \\
\text { sociais, ou quaisquer outros avanços importantes } \\
\text { na terapia. }\end{array}$ & $\begin{array}{l}\text { subverte valores fundamentais para a saúde da } \\
\text { pessoa e sua integração na comunidade. }\end{array}$ \\
\hline $\begin{array}{l}\text { promove responsabilização por si mesmo } \\
\text { (diferente de culpabilização): emerge de um } \\
\text { processo de comprometimento com o mundo. }\end{array}$ & $\begin{array}{l}\text { é utilizado para se descomprometer de uma } \\
\text { temática ou de uma troca com o meio. }\end{array}$ \\
\hline $\begin{array}{l}\text { promove experiências de pertencimento universal, } \\
\text { e contribuem para a comunidade de alguma forma } \\
\text { - seja subvertendo processos hegemônicos } \\
\text { opressores, ou viabilizando um sentido de união e } \\
\text { contribuição conjunta, etc. }\end{array}$ & $\begin{array}{l}\text { promove exclusão, ratificando processos } \\
\text { hegemônicos opressores. }\end{array}$ \\
\hline acolhe e redireciona. & condena. \\
\hline $\begin{array}{l}\text { gera insights, reestruturações cognitivas e } \\
\text { capacidade de auto-objetificação e } \\
\text { dessensibilização terapêuticas. }\end{array}$ & $\begin{array}{l}\text { reifica ideias e processos que o paciente já possui } \\
\text { e que prejudicam seus processos terapêuticos. }\end{array}$ \\
\hline $\begin{array}{l}\text { adota a estética cômica como postura de vida, } \\
\text { possuindo uma atitude subjacente de celebrar a } \\
\text { capacidade da vida de se reinventar. }\end{array}$ & $\begin{array}{l}\text { por trás desta forma estética de celebração (que } \\
\text { caracteriza a expressão do humor), transmite } \\
\text { mensagens "amargas" sobre a impossibilidade de } \\
\text { mudança. }\end{array}$ \\
\hline
\end{tabular}

Fonte: Elaboração da autora. 2016.

Esta relação entre o humor e a psicoterapia deve ser compreendida não apenas em nível de intervenção, mas também diagnóstico: a presença ou ausência do humor na clínica pode oferecer importantes indicadores quanto aos processos enumerados no quadro acima (Quadro 6).

Além disso, alguns autores compreendem que o senso de humor - discutido anteriormente como um estilo de vida saudável - deve se configurar como um dos principais objetivos de qualquer psicoterapia e uma postura central a ser desenvolvida por todo psicoterapeuta (Chazenbalk, 2005; Jacobs, 2009; Kuhlman, 1984; Richman, 2001). 
É de fundamental importância, portanto, que o psicoterapeuta possa exercitar seu senso de humor e treinar sua habilidade e sensibilidade cômicas, a fim de que possa não só aprimorar um domínio sob as trocas humoradas pontuais, como criar um clima mais bemhumorado na clínica - que favorece o desenvolvimento de um senso de humor por parte do paciente.

Mas como é possível que o terapeuta desenvolva domínio sobre um fenômeno interhumano, multifacetado e essencialmente vivencial, como o humor? A resposta a esta pergunta depende da forma como compreendemos este "domínio". De fato, não podemos desenvolver um controle sério, linear e racional sobre o humor. Contudo, podemos descobrir e afiar o nosso estado cômico que, embora não garanta a criação de uma experiência humorada na relação, permite uma maior sensibilidade e habilidade do sujeito para propor trocas humoradas na mesma.

Descobrir e afiar um certo estado, por sua vez, implica um conhecimento corporificado (Zeig, 2015). Esse conhecimento não diz respeito apenas a habilidades físicas, mas a afetos, sentimentos e sentidos incorporados nas ações, isto é: a uma lógica corporificada na forma como o corpo sente e percebe o mundo, age e reage nele (Burnier, 2009).

Neste sentido, um saber técnico e filosófico não é suficiente para permitir a apreensão do estado cômico e suas qualidades relacionais; é necessário um aprendizado que somente se dá por meio da própria vivência e prática. Estas irão permitir a descoberta do estado e o desenvolvimento de uma awareness implícita para todos os sentidos, qualidades e nuances que o constituem - como acontece quando aprendemos a andar de bicicleta -, de modo que os caminhos vivenciais para as proposições humoradas na relação e as intenções que os permeiam se tornem mais familiares. 
Nesta direção, o treinamento de iniciação ao palhaço aparece como uma alternativa preciosa ao desenvolvimento e à apropriação de um estado cômico, pois ele proporciona:

- Maior afinidade com a razão lúdica, através dos constantes jogos e brincadeiras que utiliza.

- Acesso e desenvolvimento de um estado de amoralidade, "dessacralizando" a moral vigente sem ignorá-la e propiciando, assim, um distanciamento que torna possível tanto o reconhecimento desta moral quanto a subversão inteligente de seus desdobramentos.

- Acesso e desenvolvimento de um estado de ingenuidade, ensinando o sujeito a reconhecer e utilizar as primeiras reações e lógicas que tomam conta de seu corpo antes mesmo que tenha tempo de refletir conscientemente sobre as mesmas, e que tendem a oferecer saídas inesperadas e cômicas às situações.

- Contato com a estética cômica enquanto forma de ser e estar no mundo, conduzindo a pessoa a confiar na capacidade da vida de se reinventar constantemente diante dos desafios, bem como a não desistir e esmorecer diante dos fracassos - ensinando-a a aceitá-los como parte do processo de viver e, quando possível, utilizá-los através de um oportunismo inteligente.

- Desnudamento das máscaras e mecanismos de defesa que impedem nosso contato genuíno com o mundo, possibilitando uma maior autenticidade, abertura e disponibilidade na relação.

- O aprendizado da lida com a vulnerabilidade, incentivando o desenvolvimento de uma confiança em si que não seja pautada no sucesso ou na negação do fracasso e das dificuldades, mas na coragem para ser imperfeito e na capacidade de rir de si mesmo. 
- O treino de uma escuta aguçada (awareness voltada para o entre), de um estado de prontidão, e de um calor humano e companheirismo para "jogar com”. Ademais, incentivando um aprendizado de reconhecimento da alteridade.

Neste sentido, concluímos que os conhecimentos e as práticas que constituem a arte da palhaçaria, integrados à compreensão tanto dos processos e qualidades psicoterapêuticos, como do lugar que o humor ali ocupa, poderiam não apenas ajudar o psicoterapeuta a desenvolver uma sensibilidade afiada para a utilização do humor na relação terapêutica, como também potencializar o seu senso de humor de uma forma mais geral.

A partir das observações tecidas acima, compreendemos que o presente trabalho cumpriu com a finalidade de discutir o uso do humor na psicoterapia, contemplando seus objetivos específicos, os quais eram: compreender os principais processos e qualidades que constituem o fenômeno do humor; refletir sobre o lugar deste fenômeno nas especificidades da prática psicoterapêutica; e apontar possibilidades para que o psicoterapeuta desenvolva maior habilidade e sensibilidade em seu uso.

Os diálogos e as reflexões forjadas neste trabalho nos permitem, ainda, concluir que:

1 - A psicoterapia consiste em uma atividade que faz parte integral dos processos e modos de vida daqueles que dela fazem parte. Ela possui como principal meio de trabalho o relacionamento humano e a criação de experiências terapêuticas através do mesmo. Neste sentido, a prática psicoterapêutica não deveria ignorar, excluir ou restringir um dos fenômenos básicos constituintes das relações humanas - o humor - mas, sim, aprender a lidar com ele. Mais do que isso, ao compreendermos o senso de humor enquanto uma forma de se relacionar com a vida que carrega qualidades intrinsecamente terapêuticas e fundamentais à 
saúde humana, passamos a vislumbrar a presença do fenômeno humorado na psicoterapia como uma questão de saúde mental.

Não obstante, o fenômeno do humor não se relaciona apenas com aspectos específicos da atuação psicoterapêutica, mas com alicerces de sua constituição. O humor possui um lugar fulcral nas mudanças de paradigmas da psicoterapia para paradigmas mais saudáveis: de um paradigma voltado à doença para um paradigma voltado à saúde; de um paradigma cientificista para um paradigma que considere as experiências estéticas humanas; e, principalmente, de um paradigma da seriedade para um do senso de humor.

Neste sentido, enfatizamos a importância de se abordar o humor no estudo e na prática clínica do mesmo modo como são abordados o sofrimento psíquico e as dificuldades humanas.

2 - Enquanto psicoterapeutas, é possível desenvolvermos nosso próprio senso de humor. Mais ainda, é possível aprendermos a criar intencionalmente o humor na clínica, se compreendermos que esta intencionalidade não é só racional, mas visceral, e que ela não garante a troca humorada, mas faz parte de caminhos e habilidades que constituem uma maior sensibilidade na sua proposição.

O palhaço é uma figura secular que aparece em vários contextos de cura, especialmente nas culturas dos primeiros povos. Sua formação possibilita o desenvolvimento de um estado cômico e de uma sensibilidade para propor o humor na relação de um modo que dificilmente outros ofícios cômicos possibilitam. Neste sentido, a arte da palhaçaria pode ser uma importante ferramenta no auxílio da integração do humor na psicoterapia.

Ademais, reiteramos a importância de trabalhos futuros que explorem, critiquem e avancem os diálogos que aqui construímos e as possibilidades que discutimos - no que 
concerne ao humor, à sua relação com a psicoterapia, e às contribuições da palhaçaria. Este esforço de aprofundamento, sobretudo nos estudos do humor e de seu lugar na clínica psicológica, tem uma importância especial no Brasil, onde as publicações que tratam do fenômeno do humor e de seu uso na psicoterapia ainda são escassas.

Compreendendo a psicoterapia como uma arte (Keeney, 1995; Zeig, 2015) - na qual a experiência estética ocupa um lugar central -, ressaltamos a importância de que, como na arte, também na psicologia encontremos um espaço maior para vivências práticas que:

- possibilitem o nosso encontro e afinidade com qualidades estéticas específicas como a empatia, o tato, a ludicidade e o senso de humor (Kupermann, 2003);

- intensifiquem nossa capacidade de produzir e manejar experiências estéticas na relação: desenvolvendo caminhos que possibilitem afetar mais profundamente o outro e de impactar suas experiências e processos de modo terapêutico (Zeig, 2015).

Uma importante limitação deste trabalho concerne à ausência de aprofundamento em situações específicas de psicoterapia, como na psicoterapia com crianças ou com pessoas cujos parâmetros de desenvolvimento fujam à média estabelecida pela sociedade contemporânea ocidental - casos de autismo, superdotação, esquizofrenia ou alguma deficiência cognitiva ocasionada por um acidente, por exemplo. Embora acreditemos que a base geral de nossa discussão esteja subjacente a quaisquer tipos de atendimento terapêutico, pois tratam de princípios básicos da profissão, faz-se mister destacar a importância de estudos futuros que enfoquem condições psicoterapêuticas específicas.

Também gostaríamos de destacar a importância de futuros trabalhos práticos e estudos empíricos, os quais abranjam o que foi discutido aqui de modo teórico. No mais, projetos de extensão e pesquisa que possam explorar na prática a capacidade humana de 
desenvolver seu senso de humor e a sensibilidade para proposições humorísticas saudáveis na relação, especialmente por parte de profissionais da saúde, em muito contribuiriam para desmistificar a ideologia da seriedade que permeia estes meios e proporcionar um ambiente de estudos e de trabalho mais humano e saudável. 


\section{Referências}

Assis, J. M. (2010). O riso pela lógica do Palhaço na Clinicanálise do sofrimento psíquico grave. Dissertação de Mestrado, Instituto de Psicologia - Universidade de Brasília, Brasil.

Attardo, S. (1993). Violation of conversational maxims and cooperation: The case of jokes. Journal of pragmatics, 19, 537-558.

Attardo, S. (1994). Linguistic theories of humor. Berlin/New York: Mouton de Gruyter.

Attardo, S. (2008). A primer for the linguistics of humor. In V. Raskin (Ed.), The primer of humor research (101-155). Berlin/New York: Mounton de Gruyter.

Attardo, S., \& Pickering, L. (2011). Timing in the performance of jokes. Humor, (24) 2, 233-250.

Bergson, H. (1993). O riso: Ensaio sobre o significado do cômico (2a ed.). Lisboa: Guimarães Editores.

Berky, B., \& Barbre, C. (2000). The clown's use of empathy: An interview with Bob Berky. Journal of Religion and Health, 39(3), 239-246.

Black, M. (1959). Linguistic relativity: The views of Benjamin Lee Whorf. The Philosophical Review, 68 (2), 228-238.

Bunish, C. (2012, Agosto 1). Cutting humor [em linha]. Postmagazine. Acessado em junho 30, 2015, em http://www.postmagazine.com/Publications/Post-Magazine/2012/ August-1-2012/Cutting-Humor.aspx.

Burnier, L. O. (2009). Capítulo 8: O clown e a improvisação codificada. In L. O. Burnier, A arte de ator: Da técnica à representação (pp. 205-232). Campinas: Editora Unicamp.

Cai, C., Yu, L., Rong, L., \& Zhong, H. (2014). Effectiveness of humor intervention for patients with schizophrenia: A randomized control trial. Journal of Psychiatric Research, 59, 174-178.

Camargo, D. (2012). Formação em palhaço: Reflexões sobre metodologias de formação de novos palhaços. Dissertação de Mestrado, Instituto de Artes - Universidade de Brasília, Brasil.

Castro, A. (1997). A arte da bobagem: Manual para o clown moderno. Londres: Angela de Castro \& Co.

Chazenbalk, L. (2005). El valor del humor en el processo psicoterapêutico. Psicodebate, 6, 73-83. 
Cordioli, A.V., \& Giglio, L. (2008). Como atuam as psicoterapias: os agentes de mudança e as principais estratégias e intervenções psicoterápicas. In A. V. Cordioli (Org.), Psicoterapias: Abordagens atuais (3a ed., pp. 42-57). Porto Alegre: Artmed.

Corrigan, R. (1981). Introduction: Comedy and the comic spirit. In: R. Corigan (Org.). Comedy: Meaning and form (2a ed., pp. 1-13). New York: Harper \& Row.

Dario Fo (2004). Manual mínimo do ator. São Paulo: Senac.

Dewey, J. (2005). Art as experience. New York: Perigee (Trade Paperback Edition).

Dorneles, J. L. (2003). Clown, o avesso de si: Uma análise do clownesco na pósmodernidade. Dissertação de Mestrado. Instituto de Psicologia - Universidade Federal do Rio Grande do Sul, Brasil.

Erickson, B. A., \& Keeney, B. (2006). Milton H. Erickson, M.D.: An American healer. Arizona: Ringing Rocks Press.

Erickson, M. H., \& Rossi, E. L. (1979). Hypnotherapy: An exploratory casebook. Irvington Publishers: New York.

Frankl, V. E. (2014). Man's search for meaning (6a ed.). Boston: Beacon Press.

Franzini, L. R. (2001). Humor in therapy: The case for training therapists in its uses and risks. The Journal of General Psychology, 128(2), 170-193.

Freud, S. F. (1907). Escritores criativos e devaneio. In J. Salomão (Org.), Edição standard brasileira das obras psicológicas completas de Sigmund Freud, Vol. IX (1980). Rio de Janeiro: Imago.

Freud, S. F. (1927). O humor. In J. Salomão (Org.), Edição standard brasileira das obras psicológicas completas de Sigmund Freud, Vol. XXI (1980). Rio de Janeiro: Imago.

González Rey, F. (2011). Subjetividade e saúde: Superando a clínica da patologia. São Paulo: Cortez.

Greenwald, H. (1975). Humor in psychotherapy. Journal of Contemporary Psychotherapy, 2(7), pp. 113-116.

Hempelmann, C. F. (2012). Formal humor logic beyond second-most plausible reasoning. AAAI Technical Report, 12 (2), 14-17.

Hempelmann, C. F., \& Attardo, S. (2011). Resolutions and their incongruities: Further thoughts on Logical Mechanisms. Humor, 24 (2), 125-149.

Huizinga, J. (1950). Homo ludens: A study of the play-element in culture. New York: Roy Publishers.

Hycner, R. (1995). De pessoa a pessoa: Psicoterapia dialógica. São Paulo: Summus. 
Isolan, L., Pheula, G., \& Cordioli, A. V. (2008). Fatores comuns e mudança em psicoterapia. In A. V. Cordioli (org.), Psicoterapias: abordagens atuais (3a ed., pp. 58-71). Porto Alegre: Artmed.

Jacobs, S. (2009). Humour in Gestalt therapy - curative force and catalyst for change: A case study. South African Journal of Psychology, 4 (39), pp. 498-506.

Keeney, B. P. (1995). A improvisação em psicoterapia: Guia prático para estratégias clínicas criativas. São Paulo: Psy.

Koller, D., \& Gryski, C. (2007). The life threatened child and the life enhancing clown: Towards a model of therapeutic clowning, Ecam, 5(1), 17-25.

Krimann, A. (2006). Contemporary linguistic theories of humor. Folklore: Electronic Journal of Folklore, 33, 27-58.

Kuhlman, T. L. (1984). Humor and psychotherapy. New Jersey: Aronson.

Kupermann, D. (2003). Ousar rir: Humor, criação e psicanálise. Rio de Janeiro: Civilização Brasileira.

Langer, S. (1953). Feeling and form. New York: Charles Scribner's son.

Lecoq, J. (1987). Em busca do seu próprio clown. In J. Lecoq, Le théatre du geste (p. 117). Tradução de Roberto Mallet. Paris: Bordas. Acessado em junho 20, 2016, em http://www.grupotempo.com.br/tex_busca.html.

Lecoq, J. (2010). Os clowns. In J. Lecoq, O corpo poético: Uma pedagogia da criação teatral (pp. 213-225). São Paulo: Senac.

Leef, B. L., \& Dallas, D. (2013). The sensitivity training clown workshop: Enhancing therapeutic communication skills in nursing students. Nursing Education Perspectives, $34(4), 260-264$.

Manfredi, M., Adorni, R., \& Provérbio, A. (2014). Why do we laugh at misfortunes? An electrophysiological exploration of comic situation processing. Neuropsychologia, (61), 324-334.

Matraca, M. V. C., Wimmer, G., \& Araújo Jorge, T. C. (2011). Dialogia do riso: um novo conceito que introduz alegria para a promoção de saúde apoiando-se no diálogo, no riso, na alegria e na arte da palhaçaria. Ciência e Saúde Coletiva, 16(10), 4127-4138.

Menezes, E. D. B. de. (1974). O riso, o cômico e o lúdico. Revista de Cultura Vozes, 1 (68), 5-16.

Morin, E. (2005a). Ciência com consciência. Rio de Janeiro: Bertrand Brasil.

Morin, E. (2005b). O Método 5. A humanidade da humanidade. Porto Alegre: Sulina.

Neubern, M. S. (2004). Complexidade e psicologia clínica: Desafios epistemológicos. Brasília: Plano. 
Neves, L. F. B. (1974). A ideologia da seriedade e o paradoxo do coringa. Revista de cultura Vozes, 1 (68), 35-40.

Oliveira, D. C. (2012). Formação em palhaço: Reflexões sobre metodologias de formação de novos palhaços. Dissertação de Mestrado, Instituto de Artes - Universidade de Brasília, Brasil.

Oliveira, Z. R. (2008). Dramaturgia da atuação cômica: O desempenho do ator na construção do riso. Dissertação de Mestrado, Universidade de Brasília, Brasília.

Oring, E. (2008). Humor in antropology and folklore. In V. Raskin (Ed.), The primer of humor research (183-210). New York: Mounton de Gruyter.

Oring, E. (2011). Still further thoughts on Logical Mechanisms: A response to Christian F. Hempelmann and Salvatore Attardo. Humor, 24 (2), 151-158.

Panichelli, C. (2013). Humor, joining, and reframing in psychotherapy: Resolving the auto-double-bind. The American Journal of Family Therapy, 41(5), 437-451.

Phealan, P. (1993). Unmarked: The politics of performance. Routledge: London and New York.

Pradita, I. (2010). The pragmatic aspects of humor creation: A study on Grice's cooperative principles [em linha]. Academia.edu website. Acessado em junho 26, 2015, em https://www.academia.edu/8897891/The_Pragmatic_Aspects_of_Humor_Creation_A_ Study_on_Grice_s_Cooperative_Principles.

Prerost, F. J. (1984). Evaluating the systematic use of humor in psychotherapy with adolescents. Journal of Adolescence, 7, 267-276.

Raskin, V. (1985). Semantic mechanisms of humor. Dordrecht/Boston/Lancaster: D. Reidel Publishing Company.

Raskin, V. (2008). Theory of humor and practice of humor research: editor's notes and thoughts. In V. Raskin (Ed.), The primer of humor research (pp. 1-15). Berlin/New York: Mounton de Gruyter.

Richman, J. (1996). Points of correspondence between humor and psychotherapy. Psychotherapy, 4 (33), pp. 560-566.

Richman, J. (2001). Humor and creative life styles. American Journal of Psychotherapy, $3(55)$, pp. $420-428$.

Ruch, W. (2008). Psychology of humor. In V. Raskin (Ed.), The primer of humor research (pp. 17-100). Berlin/New York: Mounton de Gruyter.

Rutherford, K. (1994). Humor in Psychotherapy. Individual Psychology, 50 (2), pp. 207222.

Shultz, D. P., \& Shultz, S. E.(2007). História da psicologia moderna. São Paulo: Thomson Learning. 
Smith, R. E. (1973). The use of humor in counterconditioning of anger responses: A case study. Behavior Therapy, 4, pp. 576-580.

Suls, J. (1983). Cognitive processes in humor appreciation. In M. Paul, \& G. Jeffrey (Eds.), Handbook of humor research (Vol. 19). New York/Berlin/Heidelberg/Tokyo: Springer-Verlag.

Sultanoff, S. M. (2013). Integrating humor into psychotherapy: Research, theory and the necessary conditions for the presence of therapeutic humor in helping relationships. The Humanistic Psychologist, 41, p. 388-399.

Tanay, A. N. L., Roberts, J., \& Ream, E. (2012). Humor in adult cancer care: A concept analysis. Journal of Advanced Nursing, 2131-2140.

Van Blerkom, L. M. (1995). Clown doctors: Shaman healers of western medicine. Medical Antropology Quarterly, 9(4), 462-475.

Wierzbicka, A. (2010). Experience, Evidence, \& Sense: The Hidden Cultural Legacy of English. New York: Oxford University Press.

Wittgenstein, L. (1991). Investigações filosóficas (3a ed.). São Paulo: Nova Cultura.

Wolberg, L. R. (1988). The technique of psychotherapy: Part one (4th ed.). Philadelphia: Grune \& Stratton.

Zanello, V. (2005). A metáfora no trabalho clínico: Ensaios teórico-clínicos acerca das funções da metáfora no processo analítico. Tese de Doutorado, Universidade de Brasília, Brasília.

Zanello, V. (2009). Filosofia da linguagem e psicanálise: Uma contribuição a partir dos atos perlocucionários. In V. Zanello, C. Carneiro \& M. N. Campos (Orgs.), Fronteiras em Psicanálise (pp. 139-147). Guarapari: ExLibris.

Zanello, V (prelo). Seminários em Psicanálise.

Zeig, J. K. (2015). Psychoaerobics: An experiential method to empower therapist excellence. Arizona: Milton H. Erickson Foundation Press. 